Portland State University

PDXScholar

$1-1-1982$

\title{
The copper complexation properties of dissolved organic matter from the Williamson River, Oregon
}

Charles Russell Lytle

Portland State University

Follow this and additional works at: https://pdxscholar.library.pdx.edu/open_access_etds

Let us know how access to this document benefits you.

\section{Recommended Citation}

Lytle, Charles Russell, "The copper complexation properties of dissolved organic matter from the Williamson River, Oregon" (1982). Dissertations and Theses. Paper 815.

https://doi.org/10.15760/etd.815

This Dissertation is brought to you for free and open access. It has been accepted for inclusion in Dissertations and Theses by an authorized administrator of PDXScholar. Please contact us if we can make this document more accessible: pdxscholar@pdx.edu. 
THE COPPER COMPLEXATION PROPERTIES OF DISSOLVED

ORGANIC MATTER FROM THE WILLIAMSON RIVER, OREGON

by

CHARIES RUSSELL LYTLE

A dissertation submitted in partial fulfillment of the requirements for the degree of

\author{
DOCTOR OF PHILOSOPHY \\ In \\ ENVIRONMENTAL SCIENCES AND RESOURCES: CHEMISTRY
}

Portland State Unlversity

1982 
TO THE OFFICE OF GRADUATE STUDIES AND RESEARCH:

The members of the Committee approve the dissertation of

Charles Russell Lytle presented August 10, 1982.

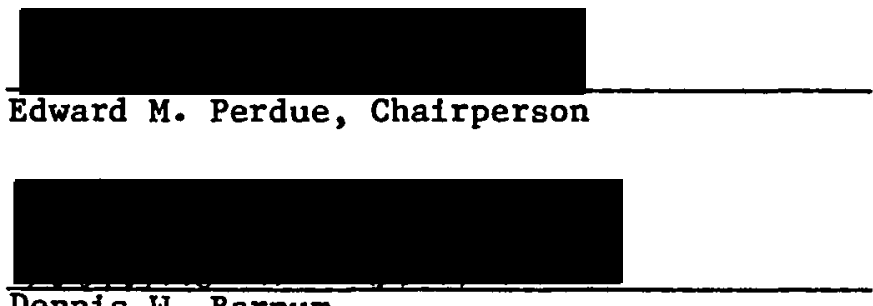

Dennis พ. Barnum
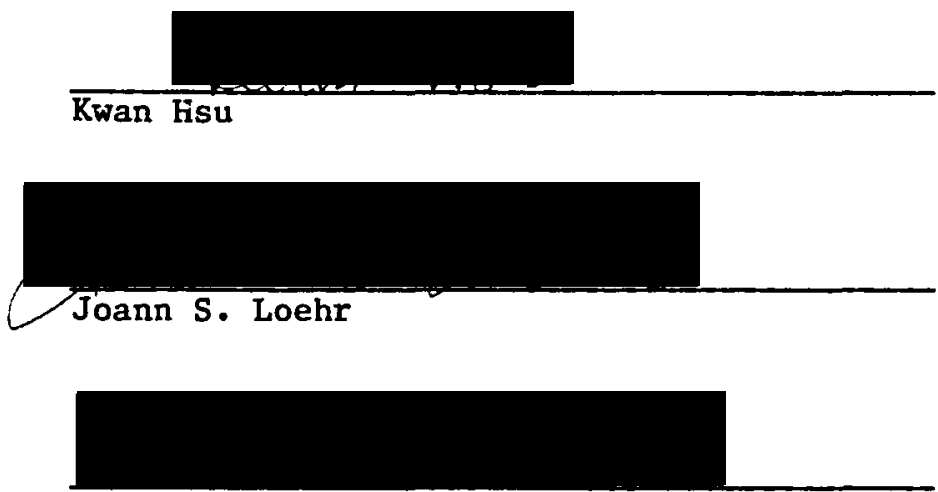

Richard R. Petersen

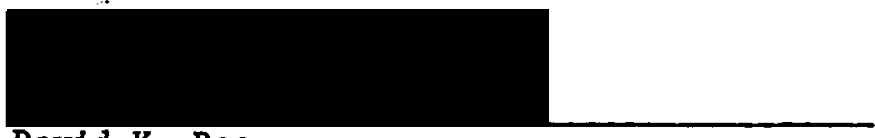

David K. Roe

APPROVED:
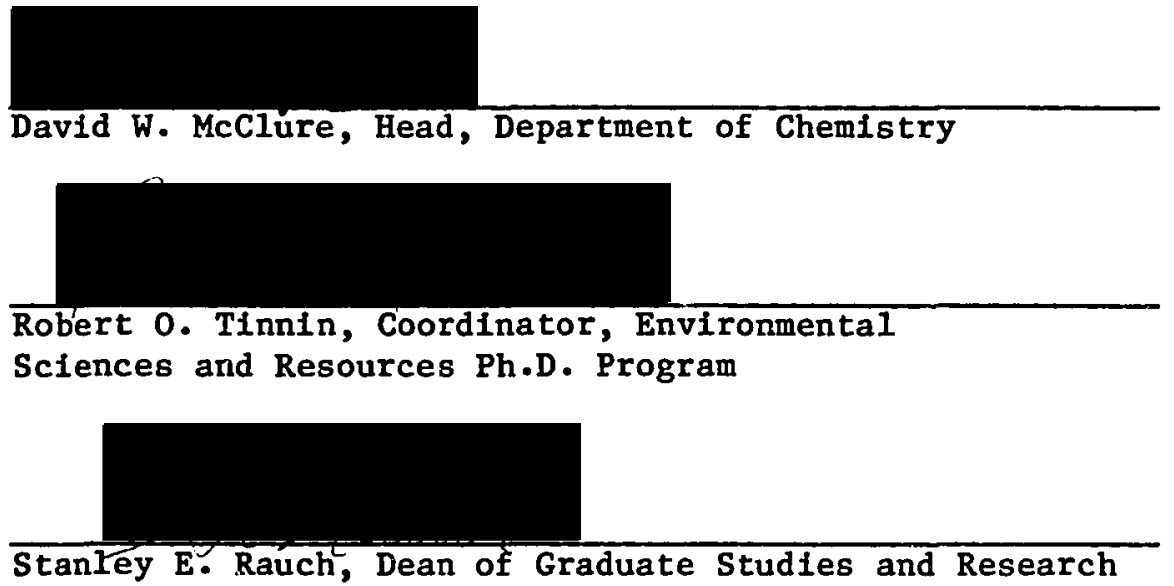


\section{ACKNOWLEDGEMENTS}

I would like to thank all the members of my comnittee for their time, criticisms, and concern over the past five years. Spectal thanks are due to Professor David Roe, who suggested the metal-ion buffer experiments and who was an invaluable resource person on all matters analytical, and Professor Mike Perdue, who thought up the whole project and directed the research.

Appreciation is extended to Karen Schwartzkoph, who typed the manuscript from a set of barely legible notes; to Dolores Oberson and Peg Pankratz, who smoothed over a plethora of administrative hurdles; to Dr. Rudy Parrish, who wrote the criginal versions of the LSTSQR and GAUSSM3 programs; and to all my graduate student friends.

Finally, the most important thank you is to Lynn C. Fox - fiance, friend, life companion - who shared all the joy and frustration, endured all the complaints and anxieties, understood the long hours and weekend work days, and provided the spiritual and physical support without which this research would have been a much more arduous task. 

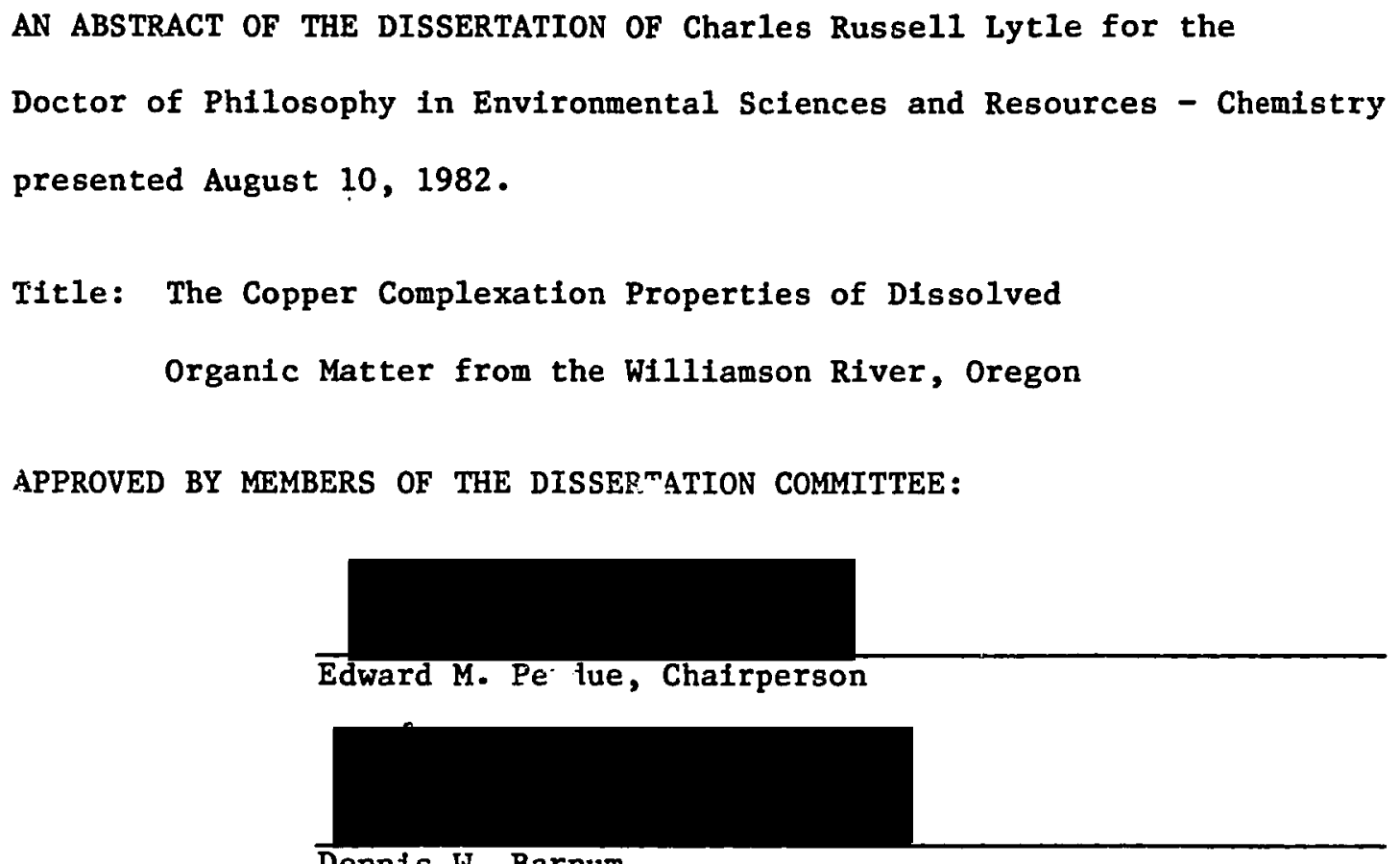

Dennis W. Barnum
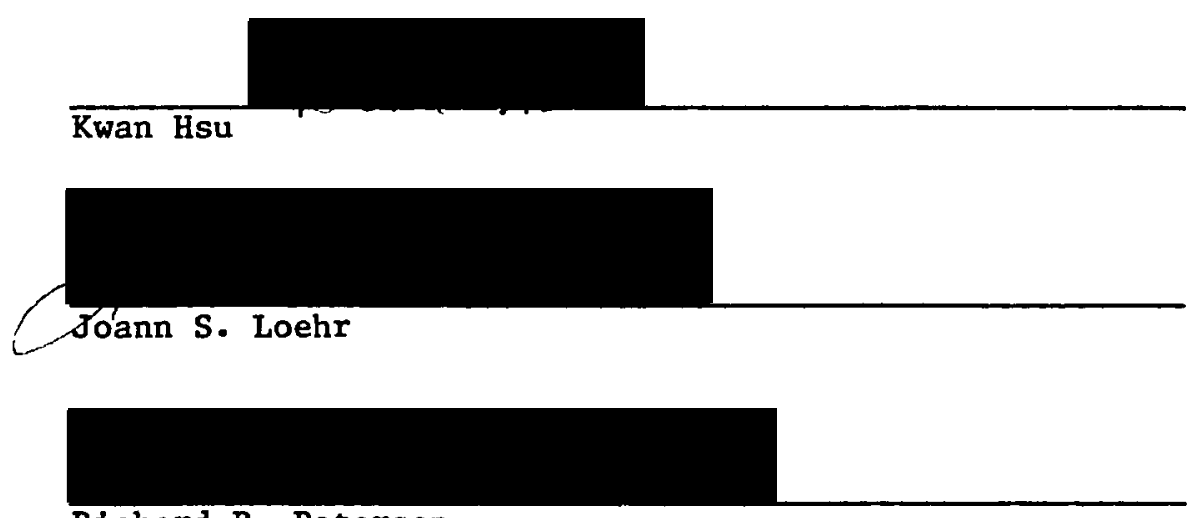

Richard R. Petersen

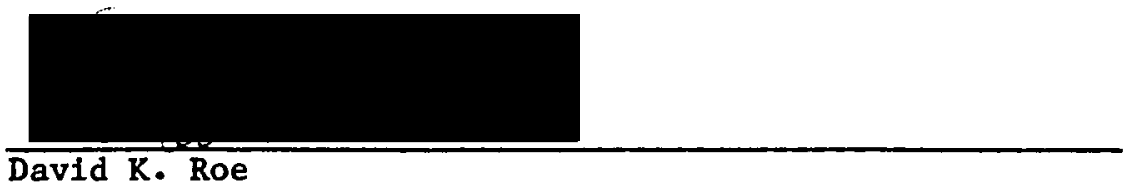


Recent research has indicated that dissolved organic matter (DOM) may plan an important role in the ability of natural waters to complex metals. This research was conducted because the quantitative nature of this role is uncertain.

Gas-1iquid chromatography was used to study the hydrolyzable amino acids at twelve sampling sites on the Willamson River at monthly intervals for two years. The relative abundances showed little spactal or temporal variation. The two-year averages for total amino acids ranged from about $0.5 \mu \mathrm{M}$ to about $8 \mu \mathrm{M}$. A separation technique was used to show that $\geq 96 \%$ of the dissolved amino acids were associated with aquatic humus. Since it was found that amino acids contributed less than $1 \%$ to humic carbon and since a published report found that carbohyrates contributed less than $2 \%$ to humic carbon, this research provided the necessary data to conclude that DOM in the Williamson River is essentially aquatic humus.

Humus complexation capacity is of ten operationally defined as amount of metal bound per unit weight of humus. This research has shown that the titrimetric methods commonly used to obtain this parameter underestimate its magnitude. However, it was shown that these methods can be combined with acidic functional group analyses to determine upper and lower limit for this parameter. For Williamson River humus, the range was $7.2-15.4 \mu m o l s$ copper per mg humlc carbon.

Titrations of humus into a copper-oxalate metal-ion buffer enabled the determination of the copper-humus binding "constant" at humus: copper ratios found in the williamson River, $\leq 4300$. The binding "constant" was a variable and a function of pH. At a humus: copper 
ratio of 4300 , the values of the function at $\mathrm{pH} 5.0,5.5,6.0$, and 6.5 were: $3.0 \times 10^{6}, 8.9 \times 10^{6}, 3.0 \times 10^{7}$, and $1.7 \times 10^{8}$. Current models of metal-humus complexation, were shown to be inappropriate via rigorous mathematical examination and via application to computer-simulated titrations. A model, in which it is assumed that the concentrations of binding sites in humus are normally distributed with respect to the $\log$ of the metal binding constant for each site, is proposed. Application of this model to simulated titrations and to experimental data proved it to be superior to other current models. 


\section{DEDICATION}

This work is dedicated to the memory of my father, the late Peter Edward Lytle. 


\begin{abstract}
We ask, "What is the answer? How can a dream be realized, any dream?" Perhaps the answer is if a dream is seen as a perfectly created material state, it is inevitably doomed to failure. Only when it is a striving toward an attainable goal can it be achleved. In short, what is attainable is spritual fulfillment and growth...

When I sit in my cabin watching the flames in my fireplace, it reminds me of countless fires I have built all over the North -- but even more, I remember that mankind has gazed into fires and dreamed his dreams for centurles. The longing for Hudson Bay is behind me, and that for all other explorations I have been on, but the great dream, that of finally growing into the vast world of comprehension and knowing, is still very much alive. This is the grandest dream of all.

At last I am beginning to belleve $I$ am part of all this 1 ife and to know how I evolved from the primal dust to a creature capable of seeing beauty. This is compensation enough. No one can ever take this dream away; it will be with me until the day I have seen my last sunset, and listened for a final time to the wind whispering through the pines."
\end{abstract}


TABLE OF CONTENTS

Page

Acknowledgements $\ldots \ldots \ldots \ldots \ldots \ldots \ldots \ldots \ldots \ldots \ldots \ldots \ldots \ldots \ldots \ldots \ldots$ 111

List of Tables $\ldots \ldots \ldots \ldots \ldots \ldots \ldots \ldots \ldots \ldots \ldots \ldots \ldots \ldots \ldots \ldots \ldots \ldots \ldots$ vili

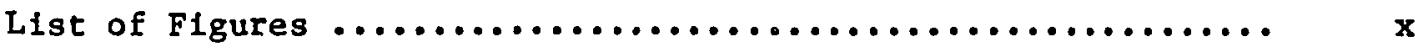

CHAPTER

I INTRODUCTION $\ldots \ldots \ldots \ldots \ldots \ldots \ldots \ldots \ldots \ldots \ldots \ldots \ldots \ldots \ldots$

Trace Metal Speciation ..................... 1

Dissolved Organic Matter in Natural Waters ....... 6

OVERALL PLAN OF THE RESEARCH $\ldots \ldots \ldots \ldots \ldots \ldots \ldots \ldots \ldots . .9$

II CHOICE OF METHODS $\ldots \ldots \ldots \ldots \ldots \ldots \ldots \ldots \ldots \ldots \ldots \ldots \ldots . \ldots \ldots \ldots$

Amino Ac1d Analysis ....................... 12

Copper-Aquatic Humus Interactions .............. 13

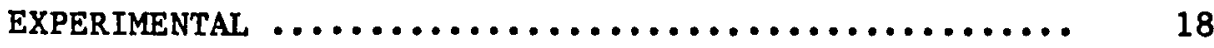

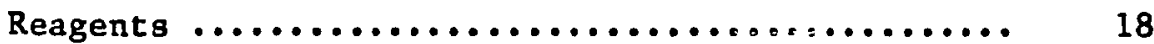

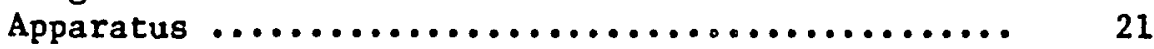

Methods for Amino Acid Analysis ................ 25

Methods for Complexation Capacity Study .......... 34

Methods for Copper-Humus Stability Function

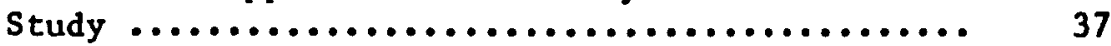

II CHEMICAL EQUILIBRIA IN MULTILIGAND MIXTURES $\ldots \ldots \ldots \ldots .40$

DISCRETE MULTILIGAND MODELS $\ldots \ldots \ldots \ldots \ldots \ldots \ldots \ldots \ldots .43$

CONTINUOUS MULTILIGAND MODELS $\ldots \ldots \ldots \ldots \ldots \ldots \ldots \ldots \ldots . . \ldots$ 
Amino Acid Study ........................ 53

The Application of the Two-Component Scatchard

Equation to Defined Ligand Mixtures ............ 61

The Application of the Continuous Distribution Model to Proton and Copper Binding by Aquatic Humus ......................... 77

The Complexation Capacity of Williamson River Humus ........................... 88

Copper-Aquatic Humus Stability Function ......... 97

SUMMARY AND CONCLUSIONS $\ldots \ldots \ldots \ldots \ldots \ldots \ldots \ldots \ldots \ldots . . \ldots \ldots$

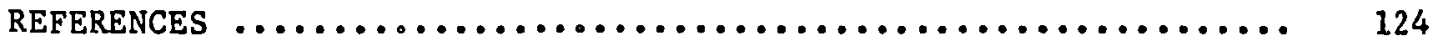

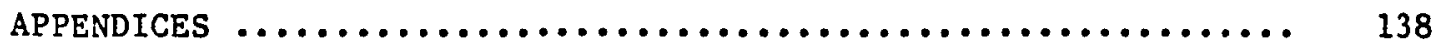

Appendix A: HATIT Program Listing ............ 138

Appendix B: SMPLX Program Listing .............. 144

Appendix C: LSTSQR and GAUSSM3 Program

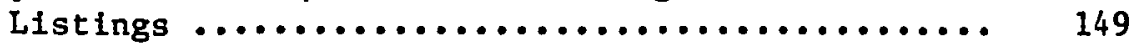

Appendix D: Amino Acid Raw Data ............... 169 
LIST OF TABLES

TABLE

PAGE

I Desalting Scheme for $0.5 \mathrm{~mL}$ Dowex $50 \mathrm{~W}-\mathrm{X4}$

Columns ................................ 27

II Conditions for Gas-Liquid Chromatography ............. 28

III Standard Curves: ng Amino Acid versus Area Amino Acld/Area $30 \mathrm{ng}$ GABA .................... 31

IV Raccoon Alpha-Hemoglobin, First 31 Residues ......... 34

$V$ Mol Percent of Amino Acids Found in the Williamson River, Averaged Over Two Years .......... 53

VI Sensitivity of Scatchard Equation Parameters to Titration Range for the Gaussian Ligand Set ...... 65

VII Ligand Set for the MINEQL Simulated Copper Titration .............................. 68

VIII Gaussian and Scatchard Fits for the Copper-Twenty Three Ligand MINEQL Simulated Titration ............ 69

IX Variation In Bimodal Gaussian Fitting Parameters with Changes in $C_{L} \ldots \ldots \ldots \ldots \ldots \ldots \ldots \ldots \ldots \ldots \ldots \ldots \ldots$

$x$ Comparison of Methods for Analyzing Complexation Capacity Data .............................. 89

XI SMPLX Determinations of the Copper-oxalate Binding Constant ..........................

XII Calculated and Found Free Copper Concentrations for a Copper-oxalate Metal Ion Buffer ............. 100

XIII Formation Reactions and Constants for the Copperoxalate Metal Ion Buffer ...................... 101

XIV Fitting Parameters for the Single and Bimodal Gaussian Modeling of the Copper Metal Ion Buffer Titrations .......................... 
XV Comparison of Fitting Parameters from this

Research and from "Calculated" Raw Data

from the Literature $\ldots \ldots \ldots \ldots \ldots \ldots \ldots \ldots \ldots \ldots \ldots \ldots \ldots$ 
LIST OF FIGURES

FIGURE

PAGE

1. Constant-Temperature Titration System ................ 24

2. Location of Sampling Sites $\ldots \ldots \ldots \ldots \ldots \ldots \ldots \ldots \ldots \ldots \ldots$

3. Fractionation Scheme $\ldots \ldots \ldots \ldots \ldots \ldots \ldots \ldots \ldots \ldots \ldots \ldots . . \ldots \ldots$

4. Typical Chromatogram: Total Amino Acids at Sampling Site KI-10, September, 1978 ............. 54

5. Seasonal Amino Acid Distribution at Selected Sampling Sites ............................. 56

6. Two-Year Averages for Total Amino Acids and Humic Carbon ............................... 57

7. Total Amino Aclds Versus Humic Carbon for the December, 1978 Field Trip ..................... 59

8. Discharge, Humic Carbon, and Total Amino Acids at Sprague River Over Two Years .................. 60

9. Amino Acid Concentrations $(\mu \mathrm{M})$ in River Water Fractions ...............................

10. Synthet1cal1y-Generated $\bar{v}$ and Calculated Fits for the Gaussian Ligand Set Using the TwoComponent Scatchard Equation ...................

11. Synthetically-Generated Log $\overline{\mathrm{K}}^{\prime}$ Values for the Gaussian Ligand Set and Log $\mathbb{R}^{\prime}$ Values Calculated from the Two-Component Scatchard Equation ..........

12. Synthetically-Generated $\nabla$ and Calculated Fits for the MINEQL LIgand Set Using the Scatchard

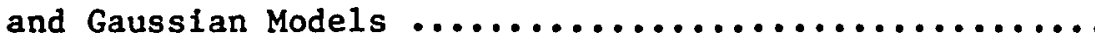

13. Simulated Log $\vec{K}^{\prime}$ Values and Calculated Fits for the MINEQL Ligand Set Using the Scatchard and Gaussian Models 
14. Comparison of Discrete and Continuous Ligand

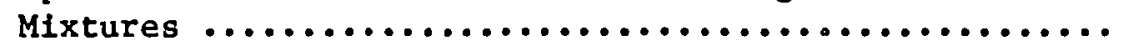

15. Variation of Scatchard Parameters with the Standard Deviation of a Continuous Distribution of

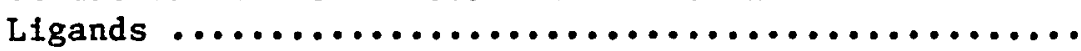

16. Computed Values of $\bar{K}^{\prime}$ and $K_{I}^{\prime}$ and $K_{\text {II }}^{\prime}$ for a Simulated Metal Titration into a Continuous,

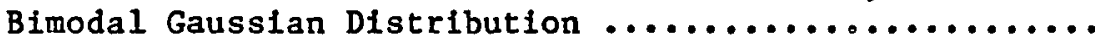

17. Base-Titratable Functional Groups Versus $\mathrm{pH}$ for a $4 \mathrm{~g} / \mathrm{L}$ Solution of Williamson River Humus

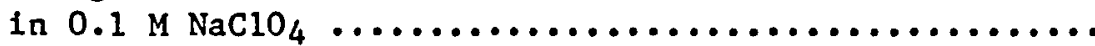

18. Experimental $\mathbf{\nabla}$ Values and Calculated Fit for the Bimodal Modeling of a Proton Titration of

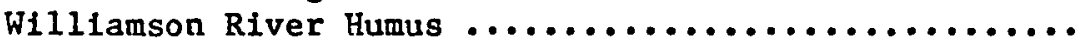

19. Bimodal Gaussian Distribution that Yielded the "Best" Fit for the Proton-Humus Titration ............

20. Experimental $\mathbf{v}$ Values and Calculated Fit Using the Gaussian Distribution Model for a Copper Titration Into Williamson RIver Humus $\ldots \ldots \ldots \ldots \ldots \ldots$

21. Data Constructed from the Scatchard Parameters of Sposito et al. (1979) and Calculated Fit Using the Gaussian Distribution Model ...............

22. Complexation Capacity Plots for $\mathrm{pH} 5$

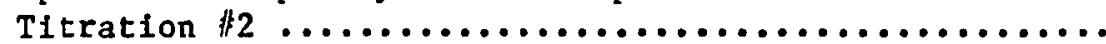

23. $\overline{\text { v Versus }} C_{M} / C_{L}$ at Various $C_{L}$ for Copper Binding to Oxalic Acid $\ldots \ldots \ldots \ldots \ldots \ldots \ldots \ldots \ldots \ldots \ldots \ldots \ldots \ldots$

24. $\bar{v}$ Versus $\mathrm{pM}$ for Copper Binding to Willlamson River Humus at $\mathrm{pH} 5.0,5.5,6.0$, and $6.5 \ldots \ldots \ldots \ldots$

25. Variability in Gaussian Fitting Parameters With

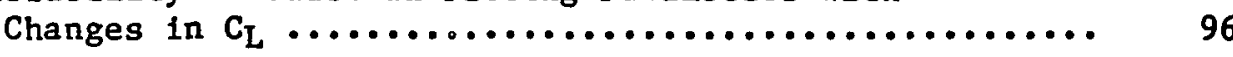

26. Copper ISE Response For $10^{-3} \mathrm{M} \geq[\mathrm{Cu}] \geq 10^{-8} \mathrm{M} \ldots \ldots \ldots \ldots$ 99

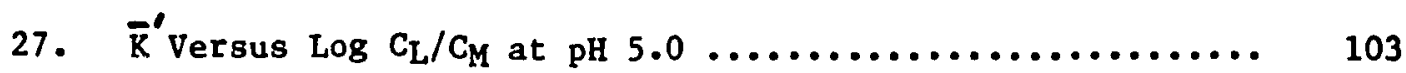

28. $\overline{\mathrm{K}}^{\prime}$ versus $\log C_{\mathrm{L}} / \mathrm{C}_{\mathrm{M}}$ at $\mathrm{pH} 5.5 \ldots \ldots \ldots \ldots \ldots \ldots \ldots \ldots \ldots \ldots$ 


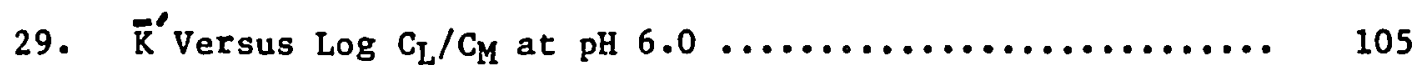

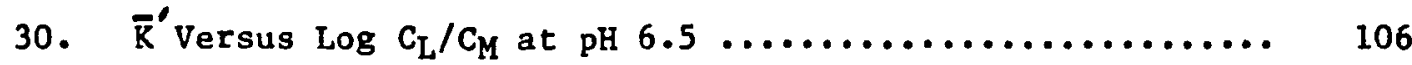

31. $\overline{\mathrm{K}}^{\prime}$ Versus $\log \mathrm{C}_{\mathrm{L}} / \mathrm{C}_{\mathrm{M}}$. One Titration Each at $\mathrm{pH}$ $5.0,5.5,6.0$, and $6.5 \ldots \ldots \ldots \ldots \ldots \ldots \ldots \ldots \ldots \ldots \ldots, 107$

32. Experimental Data and Calculated Fit for the Single Mode Gaussian Modeling of the pH 5.0

Metal Ion Buffer Titration $\|_{1} \ldots \ldots \ldots \ldots \ldots \ldots \ldots \ldots \ldots$

33. Experimental Data and Calculated Fit for the Single Mode Gaussian Modeling of the $\mathrm{pH} 5.5$

Metal Ion Buffifer Titration $\|_{1} \ldots \ldots \ldots \ldots \ldots \ldots \ldots \ldots$

34. Experimental Data and Calculated Fit for the Single Mode Gaussian Modeling of the $\mathrm{pH} 6.0$

Metal Ion Buffer Titration $\left.\right|_{1} 1 \ldots \ldots \ldots \ldots \ldots \ldots \ldots \ldots$

35. Experimental Data and Calculated Fit for the Single Mode Gaussian Modeling of the pH 6.5

Metal Ion Buffer Titration $\|_{2} \ldots \ldots \ldots \ldots \ldots \ldots \ldots \ldots$

36. $\log \overline{\mathrm{K}}^{\prime}$ versus $\log \mathrm{C}_{\mathrm{L}} / \mathrm{C}_{\mathrm{M}}$ for Gaussian Fits of Data from this Research and Data Calculatea

from the Literature $\ldots \ldots \ldots \ldots \ldots \ldots \ldots \ldots \ldots \ldots \ldots$

37. Experimental Conditions of Total Metal and Total Ligand for this Research and for Literature Reports $\ldots \ldots \ldots \ldots \ldots \ldots \ldots \ldots \ldots \ldots \ldots \ldots$ 
CHAPTER I

INTRODUCTION

\section{Trace Metal Speciation in Natural Haters}

The natural and anthropogenic occurrences of trace metals in the aquatic environment and their potentially toxic effects on biota have stimulated much current research on the chemistry of dissolved metals in natural waters. Of particular interest have been the interactions between metals and the various naturally-occurring ligands, because recent work indicates it is the chemical activity of a species of a given metal, not its stolchiometric concentration, that determines its biological effect. While aqueous metal complexation with common inorganic and simple organic ligands is well understood, the reactions between metals and dissolved organic matter (DOM) in natural waters are not well-characterized. This lack of knowledge is significant because dissolved organic carbon is second only to bicarbonate in abundance in the "world average river" (Livingstone, 1963; Schlesinger and Melack, 1981).

Johnston (1964) found that the growth of phytoplankton in sea water could be enhanced by the addition of a synthetic chelator. Barber and Ryther (1969) postulated that the enhanced growth of phytoplankton in certaln upwelling sea water was due to an increase in nutrient trace metal solubility caused by the presence of undefined natural organic chelators released by the phytoplankton themselves. Spencer (1957) and 
Erickson et al. (1970) showed that the presence of strong synthetic chelators such as EDTA and NTA reversed copper growth Inhibition of selected test marine algae. Further, Stiff (1971) showed that copper toxicity was reduced by carbonate complexation as bicarbonate alkalinity was Increased. Steemann-Nielsen and Wium-Anderson (1970) found that free copper ion, at the concentration found typically for total copper in natural waters, is toxic and concluded that copper is primarily complexed to organlc matter, in which form its toxicity is lost. Their implication that the free metal ion activity is the critical parameter in toxicity studies was postulated by Gachter et al. (1973) and confirmed by the 1mportant work of Sunda and Guillard (1976) and Kaiser (1980).

The general term "complexation capacity" has evolved to describe the ability of natural waters to bind trace metals and thus decrease their toxic effects upon biota. Chau et al. (1973) used differential pulse anodic stripping voltametry to measure the apparent complexing capacity of lake waters. Davey et al. (1973) used the sensitivity of the growth of Thalassiosira pseudonana to free copper lon activity to quantify the complexation capacity of sea water. Hanck and Dillard (1973) determined the complexation capacity of fresh waters by a novel cobalt complexation technlque. Excess cobalt(II) was added to the sample, and the cobalt(II) complexes were oxidized to chemically inert cobalt(III) complexes. The excess cobalt(II) was then analyzed by differential pulse polarography. Kunkel and Manahan (1973) used a copper(II) solub1lization technique followed by filtration and atomic absorption analysis to determine the complexation capacity of natural water and of waste 
water. No attempt was made in the above studies to determine the identitles of the complexing ligands.

The complex problem of Identifying all the bound species of a given trace metal in the aquatic environment was soon found to be a function not only of properties of the water system such as $\mathrm{pH}, \mathrm{pE}$, types and concentrations of adsorbing surfaces and types and concentrations of organic and inorganic ligands (Stumm and Belinski, 1972; Vuceta and Morgan, 1978; Andrew et a1., 1976) but also of the measurement techniques themselves (Gachter et al., 1973; Ernst et al., 1975; Campbell et al., 1977). McDuffie et al. (1976) showed that suspended solids adsorbed a large fraction of the trace metal load in a test river and that bottom sediments scavanged trace metals as their concentrations increased during low flow. This general result was also found by Pagenkopf and Cameron (1979). The importance of the sediment in the overall scheme of trace metal speciation was emphasized by Boyle et al. (1977) who postulated that adsorption onto oxide surfaces may control some trace metal concentrations in the world's oceans. The mechanisms of adsorption and current models have been recently discussed by Ballstrieri and Murray (1979), Davis and Leckle (1979), and Westall and Hohl (1980).

Studies devoted exclusively to spectation by inorganic ligands Include Pagenkopf et al. (1974) who found that the copper spectes toxic to fishes were $\mathrm{Cu}^{+2}$ and $\mathrm{Cu}(\mathrm{OH})^{+}$. Shaw and Bruwn (1974) concluded that $\mathrm{CuCO}_{3}$ was as toxic as $\mathrm{Cu}^{+2}$ to rainbow trout. Andrew et al. (1977) found $\mathrm{Cu}^{+2}, \mathrm{Cu}(\mathrm{OH})^{+}$, and $\mathrm{Cu}_{2}(\mathrm{OH})_{2}^{+2}$ were toxic to Daphnia magna. The literature dealing with the toxicities of the hydroxy and carbonate complexes of copper has been recently reviewed by Magnuson et al. 
(1979), who conclude that the carbonate complexes are not toxic, that $\mathrm{Cu}^{+2}$ and the neutral and cationic copper-hydroxide complexes contribute 60-70\% of the toxic effect and that anionic copper-hydroxide complexes are responsible for the remainder.

However, in a series of carefully controlled experiments on filtered river water, Sunda and Lewis (1978) found that Inorganic complexes accounted for only $1.0 \%$ of total copper, that natural dissolved organic matter complexes were the dominant copper species, and that the organic complexes were not toxic to a test alga, Monochrysis lutheri. The former important finding was substantiated by Giesy et al. (1978), who found for lake waters in Malne that the observed binding capacity of the water for copper and lead was almost entirely due to organic constituents, and by Van den Berg and Kramer (1979). Báccint and Suter (1979), in a study of selected Swiss lakes, found that $\geq 95 \%$ of the dissolved copper was complexed with organic ligands and that the presence of other cations, such as $\mathrm{Ca}^{+2}, \mathrm{zn}^{+2}, \mathrm{Cd}^{+2}$, in excess of copper, did not reduce the copper binding properties of the organic ligands. Even though the importance of dissolved organic matter in the trace metal chemistry of natural waters had been recognized before the above-mentioned studies (Hood, 1970; Reuter and Perdue, 1977), some researchers acknowledge and then dismiss the role of organic matter (Stumm and Belinski, 1972; Stumm and Morgan, 1970) while others employ simpie model compounds to approximace DOM in the natural environment (Vucetta and Morgan, 1978).

Even when the cation exchange capacity (CEC) of suspended solids is considered, DOM is still an important part of the overall complexation 
capacity of natural waters. For example, Livingstone (1963) reports a value of $120 \mathrm{mg}$ total dissolved inorganic solids (TDS) per liter for the world average river. Garrells and Mackenzie (1971) have shown that total suspended inorzanic solids (TSS) are about four times TDS and that particulate iron is about $30 \mathrm{mg}$ Fe per liter. Subtracting these two values gives an estimate for suspended clays of $450 \mathrm{mg} / \mathrm{L}$. An estimate for the CEC due to clays can be obtained from data given by Stumm and Morgan (1970). They report an average CEC for a 1:1 kaolinite: montmorillonite mixture of about $0.7 \mathrm{meq} / \mathrm{g}$. Thus the CEC for clays in the world average river is about $0.32 \mathrm{meq} / \mathrm{L}$. Similarly, Benjamin and Leckle (1981) report a CEC for 1ron of $1.0 \mathrm{meq} / \mathrm{g}$. Thus the particulate iron contribution towards the CEC is about $0.03 \mathrm{meq} / \mathrm{L}$, and the CEC for total suspended solids is about $0.35 \mathrm{meq} / \mathrm{L}$. Schlesinger and Melack (1981) report total organic matter in the world average river as $20 \mathrm{mg} / \mathrm{L}$. Wetzel (1975) has shown that DOM is approximately $90 \%$ total organic matter. Thus DOM is about $18 \mathrm{mg} / \mathrm{L}$, and by subtraction, suspended organic matter (SOM) is about $2 \mathrm{mg} / \mathrm{L}$. Beck et al. (1974) have found a CEC value of $10.0 \mathrm{meq} / \mathrm{g}$ for both DOM and suspended organic matter. Thus, in the world average river, the CEC for DOM is 0.20 meq/L and for suspended organics is $0.02 \mathrm{meq} / \mathrm{L}$. The sum of all four fractions, clays, fron, DOM, and SOM is 0.57 meq/L., and DOM contributes $35 \%$ of the CEC of the world average river. Thus, for such an Important constituent in the overall trace-metal speciation scheme for natural waters, detalled knowledge about the identity, concentration, and trace metal chemistry of dissolved organtc matter is clearly warranted. 
Dissolved Organic Matter in Natural Waters

One of the earliest studies on the nature of DOM in natural waters was conducted by Shapiro (1957). The extractable organic matter was in two main fractions, one yellow colored and one colorless. Both fractions gave infrared spectra indicative of a mixture of hydroxycarboxylates, both gave a positive test for phenol, and both exhibited resistance to oxidation. Their slmilarity to the organic acids found in solls prompted the label "humolimnic acids." Wilson (1959) stated that, for the colored organic fraction, this similarity was more than coincidental and that the source was soil fulvic acid carried into water through leaching by surface water. Lamar (1968) showed that there was no relation between organic color and the amount of iron present in surface waters. Further work by Christman and coworkers (Black and Christman, 1963a, 1963b; Christman and Ghassemf, 1966; Christman, 1970; Christman and Minear, 1971) using soll chemistry techniques confirmed the polyphenolic, aromatic, acidic nature of DOM and the close structural resemblance to so1l humic substances. So11 humfc substances are a complex mixture of stable, acldic polyelectrolytes possessing phenolic and carboxyl functionalities that are thought to be formed as byproducts of microbial degradation of plants (Stevenson and Butler, 1969; Schnitzer and Khan, 1972). The fulvic actd fraction is soluble in acid and base, the humic acid fraction in base only, and the humin fraction is Insoluble. Reuter and Perdue (1977) used the avallable 1iterature to conclude that $60-80 \%$ of DOM is humic substances that closely resemble soll fulvic acld and that the remainder of DOM is predominately carbohydrates and proteinaceous matter. In an assessment 
of the current data, they report concentrations of $10-13 \mathrm{mg}$ humic substances/L for the lower Mississippi River, $3 \mathrm{mg} / \mathrm{L}$ for the Columbia River, and $45 \mathrm{mg} / \mathrm{L}$ for coastal plain rivers in the southeastern United States.

Leenheer and Huffman (1976) found that $60 \%$ of the DOM in a Wyoming ground water was in the hydrophobic fraction by using separations on macroreticular resins. Leenheer (1980) found that $50 \%$ of the soluble organic matter in the Amazon River was humfc substances. He postulated that the humic substances originated from shallow solls where blomass Input exceeds decay rates and the accumulated biomass is converted to humic substances. Langford et al. (1979) found that almost all the complexation capacity of DOM was in the hydrophobic, acid fraction and stressed that aquatic humic substances are polyelectrolytes in which no two carboxyl groups are Inherently chemlcally identical.

Leenheer and Malcolm (1973) used a free-flow electrophoretic technique to fractionate DOM. They found that polysaccharides can constitute up to $10 \%$ of DOM. The literature on the carbohydrate fraction of DOM has been revlewed by Sweet (1979) who reported that values for free sugars in sea, lake, and river water have been found to be in the range of $0.1 \mu \mathrm{M}-1.1 \mu \mathrm{M}$. Semenov et al. (1967) found that protetnaceous matter constituted less than $10 \%$ of DOM in their study of selected Russian rivers. Studies on sea water (Pocklington, 1972; Lee and Bada, 1977; Macko and Green, 1979) report values for total amino acids in the range of $0.1 \mu \mathrm{M}-2.0 \mu \mathrm{M}$. Peake et al. (1972) found in their study of the Mackenzie River system that $76 \%$ of the amino acids were associated with suspended particulate matter at $1,200 \mu \mathrm{g} / \mathrm{g}$ solids. Gardner and 
Lee (1973) used gas-11quid chromatrography to analyze lake water for ten dissolved amino acf.ds and found concentrations of $2 \mu \mathrm{M}-3 \mu \mathrm{M}$.

Hullett and Eisenrelch (1979) used high-performance liquid chromatography of phenacyl ester derivatives to analyze Mississippl River water for free and bound fatty acids and found they constituted $3.3 \%$ of the dissolved organtc carbon.

It can be seen then that the quantification of the role of dissolved organic matter is an important part in the overall study of trace metal speciation in natural waters and that this quantification will primarily involve the elucidation of trace metal-humic substances interactions. This realization has important consequences in the modeling of natural aquatic systems. In recent years, a host of. sophisticated computer programs have been developed that, given the analytical concentrations of all metal fons, Inorganic and simple organic ligands, well-defined surfaces, and dissolved gases and gross parameters such as $\mathrm{pH}, \mathrm{pE}$, and temperature, will calculate the equilibrium concentration of all posstble species. (For a review of many of the currently available programs, see Nordstrom et al., 1979). While thermodynamic data are readily avallable for the binding of metals to most common Inorganic and simple organic ligands, such data for aquatic humic substances are uncertain and currently the subject of much debate in the literature (Reuter and Perdue, 1977). Because of this uncertainty, humic substances are omftted from such computer models. In light of the above discussion, it can be seen that this omission may cause significant errors when these models are applied to natural waters in which humic substances occur. What is called for is a more precise 
understanding of trace metal-humic substances interactions in the aquatic environment.

OVERALL PLAN OF THE RESEARCH

The overall goal of this research was to arrive at a better understanding of the role of dissolved organic matter in trace metal transport in a particular river system. It was hoped that the results of this work would find a broader application to natural fresh waters in general.

The first problem was the selection of an appropriate river to study. Highly colored streams draining marshes or swamps contain unusually high concentrations of DOM and are thus often the most advantageous natural systems for studying the role of DOM in natural processes. The Williamson River in Klamath County, Oregon not only possesses high concentrations of DOM but also provides a unique "before-and-after" situation. The river begins as a clear spring, flows about 25 miles through basaltic terrain, and then drains into Klamath Marsh. After passing through the marsh, the river is dark brown in color and contains high concentrations of DOM. After joining Spring Creek and the Sprague River, the Wllliamson drains into Upper Klamath Lake, about 35 miles from the Marsh (Peterson and McIntyre, 1970; Leonard and Harris, 1974). Since the Williamson provides about $46 \%$ of the water and nutrients flowing Into Upper Kiamath Lake, the river is also a logical focus for one of the causes of the lake's intense, seasonal bloom of the cyanobacterlum Aphanlzomenon flos-aquae (Miller and Tash, 1967; Gahler, 1969). As part of the larger study of 
the river system, this researcher and co-workers completed a two-year, In-depth survey of the Williamson and its major tributarles (Perdue et a1., 1981).

The second problem was the characterization of the three main DOM fractions in the Williamson River. While humic substances can be readily estimated via their color at $420 \mathrm{~nm}$ (Blunk, 1982), analysis for the carbohydrate and protelnaceous fractions is non-routine. The focus of this research was on the protelnaceous fraction. The abundance and fractionation of the carbohydrate portion was a thesis project of a coworker (Sweet, 1979).

The third problem was the determination of the complexation capacity of Willamson River DOM towards the test trace metal, copper. Copper was chosen because of the many analytical techniques available for its measurement and because of its ubiquity in natural waters (Hutchinson, 1957). Complexation capacity data allows the calculation of an operational molar concentration unit for DOM in terms of equivalents of metal bound per unit weight of DOM. This number then can be used in equilibrium calculations involving meta1-DOM interactions.

The fourth and final problem was the estimation of the extent of copper-DOM binding in the Williamson River. This can be accomplished by calculating the copper-DOM binding constant at the DOM:copper ratio found in the Williamson River and/or by using modeling techniques to extrapolate data found at higher laboratory concentrations of metal and DOM down to levels that are environmentally revelant.

In summary, the results presented in this thesis are intended to: (1) quantitate the protelnaceous portion of dissolved organic matter 
occurring in the Williamson River, Oregon; (2) quantitate the complexation capacity of this DOM for the test metal copper; (3) quantitate the copper-DOM binding constant at DOM:copper ratios found in the Williamson River; (4) model the variable nature of this binding constant at these same, environmentally relevant ratios. 
CHAPTER II

CHOICE OF METHODS

Amino Acid Analysis

Comon techniques for the quantification of amino acids from proteln hydrolysates include partition chromatography on silica columns, two-dimensional paper chromatography, high-voltage paper electrophoresis, thin-layer chromatography, lon-exchange chromatography, gas-liquid chromatography, and high performance liquid chromatography (Blackburn, 1968; Husek and Macek, 1975; Bayer et al., 1976). Because of experimental simplicity, analysis using the automated, ion-exchange analyzer has become the standard method since the instrumerts first introduction in the late 1950's (Spackman et al., 1958). Two disadvantages are the relative high cost of the instrument and its singlepurpose design. High performance liquid chromatography offers high speed (typical analysis time is $30-45$ minutes) and a lower instrument cost. New specific flourescent derivative techniques (Lindroth and Mopper, 1979) have made possible direct analysis of natural water samples. At the time this research was initiated, neither of these two instruments were available. of the remaining techniques, only gasliquid chromatography offered both the sensitivity and the operational ease desired. The latter facet was critical in the cholce due to the large number (almost 300) of analyses to be done. The large array of derivatization methods and their relative merits have been reviewed 
(Husak and Macket, 1975). Most of these methods Involve the formation of an ester at the carboxylate group and an amide at the alpha-amine group. The cholce of alcohol and anhydride used is determined by amino acid solubility in the reagents, ease of derivative formation, derivative volatility and stability, avallability of suitable chromatographic 11quid phase, chromatographic elution profile, detector sensitivity to the derivatives, etc. Detection limits are typically in the nanogram range, and use of fluoronated anhydrides and electron capture detection can lower these limits into the picogram range (Zumwalt et al., 1971). The agreement of results found by gas-liquid chromatography and by the automated, Ion-exchange analyzer has been demonstrated (Tajima, 1978; Burleson et al., 1980).

The derivatization procedure of Zanetta and Vincendon (1973) Involves esterification with isoamyl alchol and acylation with heptafluorobutyric anhydride. It was chosen because a readily-avallable, stabile liquid phase is used and because the derivatives are not subject to volatility loss during drying steps. The modification of using acetyl chloride/alcohol instead of $\mathrm{HCl} / \mathrm{alcohol}$ (Felker and Bandurski, 1975) was used because of its experimental simplicity.

Copper-Aquatic Humlc Substances Interactions

The methods used to investigate the complexation capacity of natural waters and the binding of trace metals to aquatic humfc substances largely center on the measurement of the metal of interest, as free metal ion activity, total metal concentration, or both. often, metal determination is combined with a separation technique to determine spe- 
ciation in a natural water system. Thus, while the actual determination of metal is generally confined to a few instrumental techniques (for example, voltammetry, pocentiometry, atomic absorption spectroscopy), the experimental methods employing these techniques are many and varied. They can be conveniently grouped as direct and indirect electrochemical titrations, chromatographic separations, and miscellaneous.

In the miscellaneous category, the cobalt(III) complexation method of Hanck and Dillard (1973) and the copper(II) solubilization technique of Kunkel and Manahan (1973) have already been discussed. Van den Berg and Kramer (1979) used a dispersion of manganese dioxide as a weak ion exchanger to estimate the complexing capacity of natural water for copper. Truit and Weber (1981) used membrane dialysis to separate free metal from complexes with fulvic acid and measured total and free metal concentrations by atomic absorption spectrophotometry (AAS). Ryan and Weber (1982) used the loss of fluorescence of fulvic acid upon binding with metals as a measure of the amount of metal bound. Ultrafiltration and ion selective electrodes were used by Ramamoorthy and Kushner (1975) to determine the complexing capacity of molecular weight fractions of DOM in estuarine waters. A similar methodology was employed by Smith (1976), who used anodic stripping voltammetry (ASV) to measure metal. U1trafiltration was combined with dialysis by Guy et al. (1975) and Guy and Chakrabarti (1976) in a similar size fractionation scheme. Both AAS and ASV were used to measure metal. Tessler et al. (1979) used a sequential extraction technique to speciate eight metals into five groups: exchangable, bound to carbonates, bound to iron/manganese oxides, bound to organic matter, and residual. 
Mantoura and Riley (1975), Mantoura et al. (1978), and H1rata (1981) used Sephadex gels to chromatographically separate humlc-bound species from free metal and used AAS to analyze for total metal before and after separation. Bowen et al. (1979) combined gel filtration with gamma counting of radio-isotopes to Investigate $\mathrm{Sb}, \mathrm{Hg}$, and $\mathrm{Zn}$ complexation with humic substances. In the Ion-exchange technique, the competitive equilibria of an exchange resin and of humic substances for binding to a test metal are used to provide data for complexation capacity calculations. This method has been in use for many years by soll scientists (for example, Gamble et al., 1970), who generally follow the experimental procedures of Schubert (1948). An Important modification of the basic method, allowing its use for metal-polyelectrolyte complexes, was developed by Ardakant and Stevenson (1972). The mathematical expressions derived from the techaique were rigorously examined by MacCarthy and Mark (1977) and MacCarthy (1977a) and applied to mono-and polynuclear complexes by MacCarthy (1977b). Crosser and Allen (1977, 1978) applied the technique to soluble test ligands in water and to industrial wastewater, using AAS to measure metal concentration. Chelating resin has been used by Batley and Florence (1976) and Florence (1977) along with UV irradiation to determine seven species of copper, lead, cadmium, and zinc in natural waters. Metal was determined in the various fractions by ASV. Sturgeon et al. (1980) compared chelating resins and solvent extraction as techniques for metal preconcentration In spectation studies and found both methods gave comparable results. Indirect electrochemical titrations make use of the fact that metal-humic substances complexation proceeds with release of protons. 
The extent of metal binding is quantified by titrating solutions of humics substances with base before and after equilibration with metal (Gamble, 1973). The technique was used by Stevenson et al. (1973) and Stevenson (1976) to measure stability constants of humic substances binding to copper, lead, and cadmium.

Direct electrochemical titrations make use of ion selective electrodes or anodic stripping voltammetry to measure free metal Ion and/or "labile" metal complexes. The lon selective electrode (ISE) has received much attention because it measures free metal ion activity and thus does not require a separation step to remove bound metal. Its main drawback is a loss of sensitivity at concentrations less than $10^{-7} \mathrm{H}$. The early work of Stiff (1971) has already been discussed. Gardiner (1974) used the cadmium ISE to study complex formation in a variety of waters. He extended the sensitivity limit of the electrode to environmental levels by extrapolation of standard curves found at higher concentrations. Cheam (1973) and Cheam and Gamble (1974) studied mercury, cadmium, and copper binding to solutions of fulvic acid to arrive at binding constant data. Bufflé and co-workers have studied the complexation of aquatis humic substances using the copper (Bufflé et al., 1977, 1980) and lead (Greter et al., 1979) ISE, and Bufflé (1980) has compared the results for copper with data from other researchers. Sposito and co-workers have likewise studied the complexation of sewage sludge using the calcium (Sposito et al., 1978) and copper (Sposito et al., 1979; Sposito and Holtzclaw, 1979) ISE. Weber and co-workers have studied water- and soll-derived fulvic acid complexation using the copper (Bresnahan et al., 1978), cadmiun (Saar and Weber, 1979), and lead (Saar 
and Weber, 1980) ISE.

Anodic stripping voltammetry (ASV) shares with ISE the features of low cost, operational ease, selectivity, ability to make direct measurements on environmental samples, and sensitivity to free metal ion. It has the additional advantage of detection limits for several trace metals to $10^{-10} \mathrm{M}$. Matson (1968) studied the application of ASV to environmental analysis, and Allen et al. (1970) studied free and acidexchangable copper and lead in river and lake water. The use of ASV in complexation capacity studies and in various fractionation schemes has been discussed above. Direct titrations to determine the binding constants for copper-DOM complexes in natural waters have been reported by Shuman and Woodward (1977). O'Shea and Mancey (1976) used peak current and peak potential measurements during metal-humic acid titrations to show that copper forms a strong, nonlabile complex.

For the research to be conducted for this thesis, the miscellaneous techniques were rejected because of their experimental complexity. Separation techniques utilizing ion exchange or chelating resins could not be used because of the signficant adsorption of humic substances onto such resins (MacCarthy, 1974). While ASV has a distinct advantage over ISE in detection limits, it possesses several important disadvantages. One is that metal complexes with binding constants less than $10^{13}$ are dissoctated, and the previously-complexed metal is measured as free metal ion (Matson, 1968; Chau et al., 1974). A second disadvantage is that humic substances adsorb onto mercury, causing spurious results (Allen et al., 1976; Bufflé and Cominoli, 1981), although Weber and Cheng (1979) have shown that this problem is lessened 
by using wax-sealed graphite electrodes. While the ISE does not suffer from a severe adsorption problem and is sensitive only to free metal Ion, its higher detection limit and slow response times at low lon levels are important drawbacks (Blaedel and Dinwiddie, 1974). However, 11near response can be lowered to $10^{-12} \mathrm{M}$ through the use of metal-ion buffers (Sunda and Lewls, 1978; Stella and Granzer11, 1979). Thus it was felt that the copper ISE would offer the maximum Information with the mintmum number of problems.

\section{EXPERIMENTAL}

\section{$\underline{\text { Reagents }}$}

Acetonitrile. Acetonitrile (Matheson, Coleman, Bell-Spectra Quality) was used without further purification.

Acetyl Chloride. Acetyl chloride (Baker - Instra-analyzed) was refluxed one hour with dimethylanfline and then distilled. The $51.0^{\circ} \mathrm{C}$ fraction was taken (Voge1, 1974).

Amino Acids. Amino acids (Sigma) were used without further purification.

Ammonta. Aqueous ammonia, 28.5\% (Baker - Reagent grade), was used to prepare a $2.0 \mathrm{M}$ solution.

Cupric Nitrate. Cupric nitrate solutions, $0.1000 \mathrm{M}$ and $0.01000 \mathrm{M}$, were prepared directly by dissolving primary-standard copper metal in concentrated nitric acid (Kennish, 1979).

Dimethylaniline. Dimethylaniline (Baker - Reagent grade) was passed through two alumina columns (M. Woelm) and used immediately. Dowex 50W-X4, 200/400. Dowex 50W-X4 (Blorad) was purifled by the 
method of Kaiser et a1. (1974) and stored at $5.0^{\circ} \mathrm{C}$.

Ethyl Acetate. Ethyl acetate (Baker - Instra-analyzed) was used without further purification.

Heptafluorobutyric Anhydride. Heptafluorobutyric anhydride (Pierce - $1 \mathrm{~mL}$ ampules) was stored at $-10^{\circ} \mathrm{C}$ and used without further purification.

Humic Substances Solutions. Solutions of humic substances with nominal concentrations of $1.0 \mathrm{~g} / \mathrm{L}$ and $10.0 \mathrm{~g} / \mathrm{L}$ were prepared by dissolving freeze-dried aquatic humus isclated from the Hilliamson River in purified water. The $\mathrm{pH}$ was adjusted to 6.0 and the solutions stirred at room temperature for two hours and then refrigerated at $5^{\circ} \mathrm{C}$ overnight. The solutions were then centrifuged at $2.5 \mathrm{~K} \mathrm{rpm}$ for 0.5 hour, and the supernatants filtered through $0.45 \mu \mathrm{m}$ Millipore filters. The filtrates were quantitatively transferred to volumetric flasks and the flasks filled to the mark. The $500 \mathrm{~mL}, 1.0 \mathrm{~g} / \mathrm{L}$ solution was stored at $5^{\circ} \mathrm{C}$ in a one liter, brown linear polyethylene bottle, after degassing with prepurified $\mathrm{N}_{2}$. The $50 \mathrm{~mL}, 10 \mathrm{~g} / \mathrm{L}$ solution was stored at $5^{\circ} \mathrm{C}$. The solutions were analyzed on a Dohrman total organic analyzer and found to be $382 \mathrm{mg} \mathrm{C/L}$ and $4500 \mathrm{mg} \mathrm{C} / \mathrm{L}$ (Hedges, 1982).

Hydrochloric Acid. Hydrochloric acid, 38\% (Baker - Reagent grade), was used directly for the hydrolysis reactions and used to prepare a $2.0 \mathrm{M}$ solution.

Isopentyl Alcohol. Isopentyl alcohol (Baker - Reagent grade) was refluxed over magnesium turnings for one hour, then distilled. The $127.0^{\circ} \mathrm{C}$. fraction was taken and stored over activated molecular sieve pellets, type $13 \times$ (Matheson, Coleman, Bell). The brown bottles were 
stored at room temperature in a desicator over Indicating Drierite.

Isotopes. Carbon-14 labeled algal proteln and algal protein hydrolysate (ICN Pharmaceuticals) and tritium-labeled glycine and glutamic acid (New England Nuclear) were stored at $5^{\circ} \mathrm{C}$.

Methanol. Methanol (Baker - Reagent grade) was refluxed one hour over magnesium turnings and then distilled. The $65.0^{\circ} \mathrm{C}$ fraction was taken and stored Identically to the 1sopentyl alcohol.

Nitric Acid. Nitric acid, $70.5 \%$ (Baker - Ultrex grade), was used to prepare an approximately $35 \%$ solution.

Perchloric Acld. Perchloric acld, 70\% (Mallinckrodt - AR grade), was used to prepare solutions of about $1.0 \mathrm{M}$ and $5.0 \mathrm{M}$ which were standardized at $0.9995 \pm 0.0005 \mathrm{M}$ and $5.56 \pm 0.01 \mathrm{M}$ by volumetric titration against standardized sodium hydroxide (Perdue, 1982).

Sodium Azide. Sodium azide (Mallinckrodt - AR grade) was used without further purification.

Sodium Hydroxide. Sodium hydroxide, 50\% w/w (Baker - Reagent grade) was used to prepare solutions of about 0.1 and $2.0 \mathrm{M}$, which were standardized at $0.0964 \pm 0.0002 \mathrm{M}$ and $1.516 \pm 0.002 \mathrm{M}$ by volumetric t1tration against primary standard potassium hydrogen phthalate (Koh1toff et al., 1969). A $10 \mathrm{M}$ solution was prepared by simple dilution. Sodium Oxalate. Sodium oxalate (Merck - Primary standard grade) was drled for two hours in vasuo at $25^{\circ} \mathrm{C}$ over $\mathrm{P}_{2} \mathrm{O}_{5}$ and stored at room temperature in a desicator over Indicating Drierite.

Sodium Perchlorate. Sodium perchlorate was prepared by titrating $250.0 \mathrm{~mL}$ of standardized $5.56 \mathrm{M}$ perchoric acid with a $10 \mathrm{M}$ sodium hydroxide solution to $\mathrm{pH} 7.00$ and diluting the solution to $500.0 \mathrm{~mL}$. 
The final concentration was $2.496 \mathrm{M}$.

Triethylamine. Triethylamine (Baker - Reagent grade) was redistilled, taking the $88-89^{\circ} \mathrm{C}$ fraction.

Water. All solutions were prepared with water that had passed through a Barnstead Nanopure water purification system consisting of a reverse-osmosis pretreatment followed by a granulated carbon organic cartridge, two mixed bed ion exchange cartridges, and a $0.22 \mu m$ membrane filtex. The product water was regularly checked with a Chemtrix conductivity meter, Model 70 , and the cartridges replaced if the water was above $2.0 \mu \mathrm{MH} 0 / \mathrm{cm}^{2}$. Typical values were in the range 0.2 to 0.8 rMHo/cm ${ }^{2}$.

XAD-7 Resin. XAD-7 macroreticular resin (Rohm and Haas) was soxhlet extracted with methanol as recommended by the manufacturer (Rohm and Haas, 1971).

Apparatus

Atomic Absorption Spectrophotometry. AAS measurements were made on an Instrumentation Laboratory Model 551 equipped with a Model 555 graphite furnance.

Calculations. Calculations requiring a computer were run on a Hewlett-Packard Model 85, a Rockwell AIM-65, a Tektrorix Model 31, or the PSU Honeywell Model 66/20.

Centrifugation. Centrifugation of Williamson River water was accomplished in a Sorvall SS-3 centrifuge equipped with a Model KSB-3 continuous flow system.

Derivatization System. Derivatizations for the amino acid analysis 
were done In $3 \mathrm{~mL}$ Reacti-vials (Plerce Chemical Company) equipped with Teflon-lined screw caps. The vials were heated in a milled aluminum block mounted on a Corning Model PC-35 hotplate.

Gas-Liquid Chromatography. GLC measurements were made on a Hewlett-Packard Model 5750 equipped with flame Ionization detection. The column used for the amino acid analyses was 12-FT, 2-mm I.D. glass (Supelco), Packed with 3\% SE-30, 100/120 Gaschrom-Q (Applled Science Laboratories) using the method of Leibrand and Dunham (1973). Chromatographic peak areas were automatically calculated by a Hewlett-Packard reporting Integrator, Model 3380A.

Glassware. Glassware for the amino acld study was washed in detergent, rinsed with purifled water, soaked overnight in hot, alcoho11c potassium hydroxide, and rinsed with purified water. Labware for the copper-humic substances studies was Nalgene linear polyethylene (LPE). LPE was chosen because it has been shown to cause the least loss of trace metals when compared to pyrex and Teflon (Batley and Gardner, 1977; Subramantan et a1., 1978). There 1s some disagreement on the best cleaning procedure (Mart, 1979; Laxen and Harrison, 1981). For these studies, all LPE labware was washed in detergent, rinsed with purified water, soaked overnight in $35 \%$ nitric acid, and rinsed with purified water. For work involving the AAS, LPE labware was given a final rinse with $70 \%$ nitric acid (Roe, 1981). Volumetric labware was calibrated by quadruplicate weighings of water contained or delivered (Kolthoff et al., 1969).

Potentiometry. Potenciometril measurements of $\mathrm{pH}$ were made with either a Ross combination electrode (Orion Model 81-02) or a glass 
electrode (Corning Model 476022) and a double-junction reference electrode with $1.0 \mathrm{M} \mathrm{NaNO}_{3}$ in the outer chamber (Orion Model 90-02). The electrodes were attached to an Orion Model 611 digital $\mathrm{pH} / \mathrm{mv}$ meter. Copper Ion measurements were made with a copper ISE (Orion Model 94-29) and the above double-junction reference electrode attached to a Hewlett-Packard Digital Multimeter, Model 3490A.

\section{Iiquid Scintillation Counting- All liquid scintillation counting} was done in $10 \mathrm{~mL}$ Aquasol (New England Nuclear) in $20 \mathrm{~mL}$ disposable glass scintillation jars (Kimble) in a Beckman Model Ls9000 liquid scintillation counter using standard window settings for tritium and carbon-14. The use of the counter was generously provided by the Department of Neurology, Oregon Health Sciences University.

Titration System. Titrations to determine the copper-oxalate binding constants, the complexation capacity of isolated Willamson River humic substances, and the copper-humic substances stability function were conducted in a constant temperature bath equipped with a Brinkmann Model K-21R circulator/refrigerator and a Tronac Precision Temperature Controller Model PTC-40. Temperature was maintained at $25.01^{\circ}$ C. Titrant was added by a Gilmont $2.5 \mathrm{~mL}$ Ultraburet Model $53200 \mathrm{~A}$ with micrometer readout to $0.1 \mu \mathrm{L}$, motor-driven by a Rockwell Alm-65 microcomputer. The titration vessel was milled from solid Teflon with a screw cap drilled out to accept $\mathrm{pH}$, reference, and copper electrodes. Three other ports allowed for bubbling or sweeping the top of the solution with gas and the addition of titrant. A schematic of the system is shown in Figure 1 . 


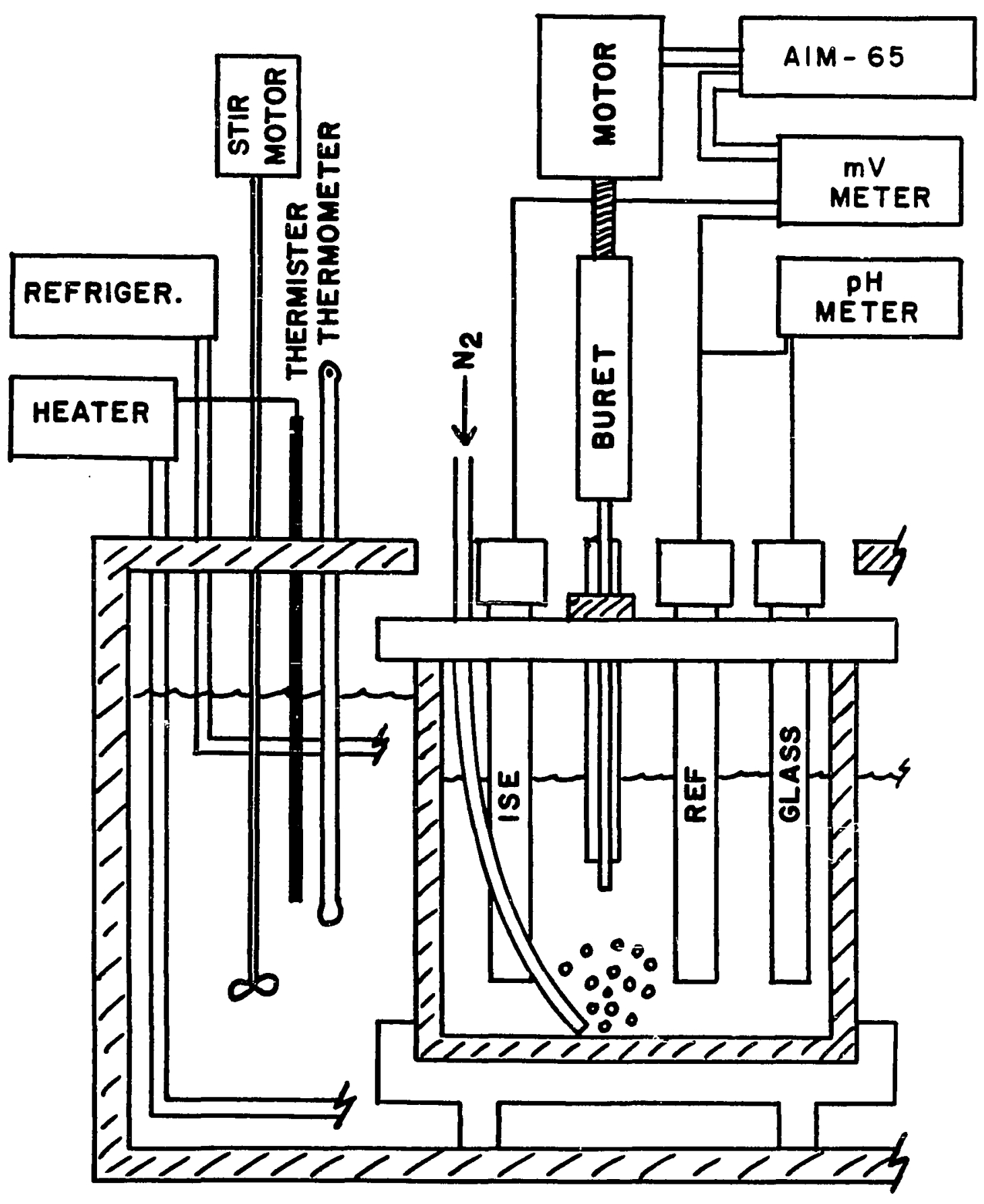

Figure 1. Constant-Temperature Titration System. 
Methods For Amino Acid Analysis.

Sampling. From September, 1977 through September, 1979, samples were taken monthly from twelve sampling sites along the Williamson River and its tributaries. The approximate location of these sites is shown in Figure 2 .

Abnormally low snow pack in the Cascade Mountain Range prior to and during this study lowered discharge into Klamath Marsh to the extent that no flow occurred out of the marsh through sampling site WR-50 during the three fall seasons observed. Flow did occur at site WR-56 because of numerous springs along the river betwen WR-50 and WR-56. No samples were taken at BS-10 during the winter months because of inaccessability due to snow.

Stream samples for the monthly survey were collectd in 65-mL LPE bottles and preserved in $3 \mathrm{mM}$ sodium azide and stored at $5^{\circ} \mathrm{C}$ until derivatization. Samples for the fractionation study were taken in January, 1980 at WR-21, WR-32, and WR-50 in 4-L LPE bottles and preserved in $3 \mathrm{mM}$ sodium azide. Before storage at $5^{\circ} \mathrm{C}$, the samples were deaerated for 15 minutes with prepurified nitrogen.

Chromatography. Elution regimes for the Dowex 50W-X4, 200/400 columns used In desalting hydrolysates were determined by the liquid scintillation monitoring of tritiated glycine and glutamic acid test elutions. The desalting scheme for the $0.5 \mathrm{~mL}$ columns is given in Table I.

Recovery off the $0.5 \mathrm{~mL}$ Dowex $50-\mathrm{W}-\mathrm{X} 4$ columns was determined in triplicate by CLC analysis of a known, seventeen-amino acid mixture. The average column yield was $75 \pm 3 \%$. 


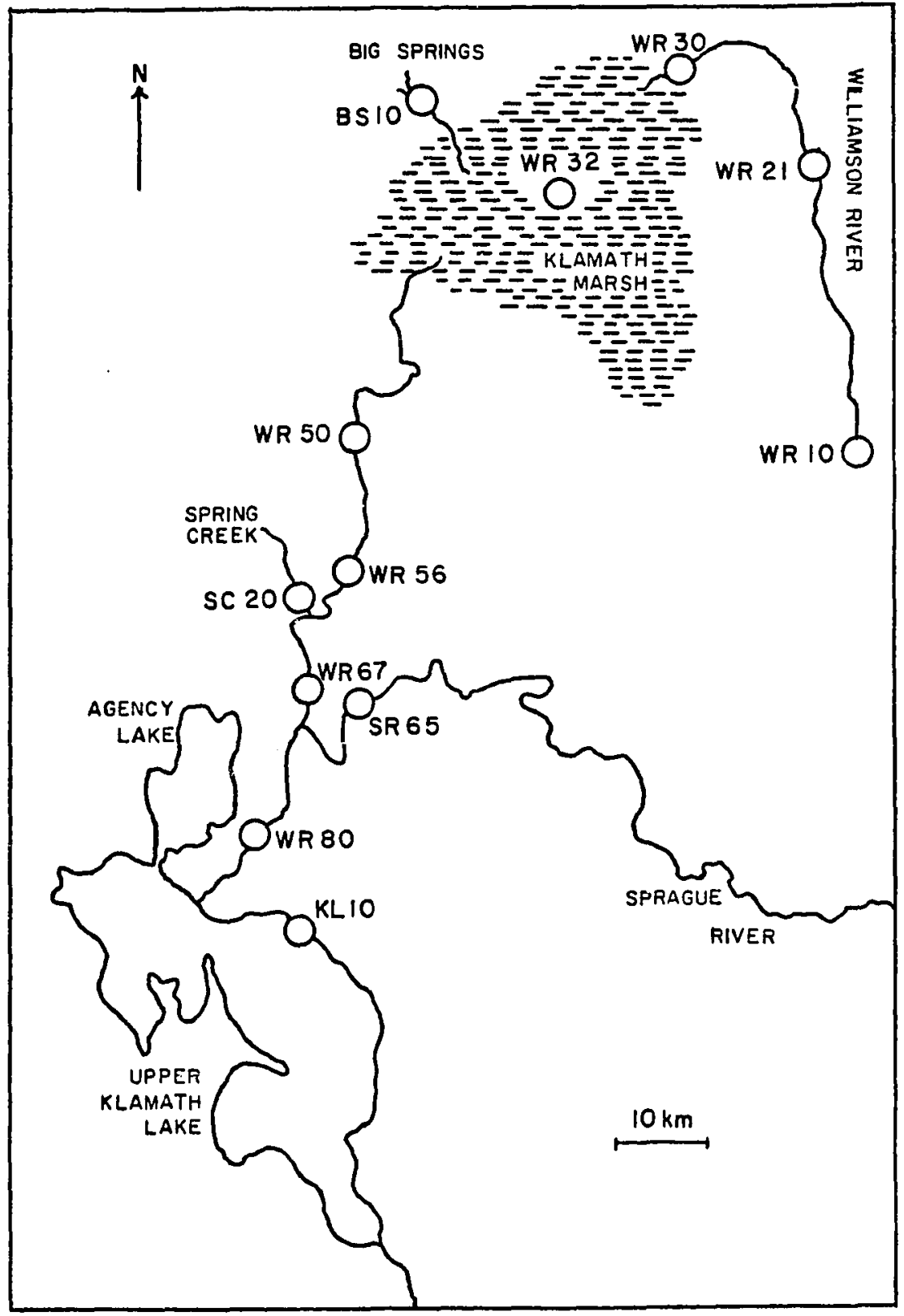

Figure 2. Location of Sampling Sites. 
TABLE I

DESALTING SCHEME FOR $0.5 \mathrm{~mL}$ DOWEX 50W-X4 COLUMNS

\begin{tabular}{clll} 
STEP & RESULT & VOLUME & \multicolumn{1}{c}{ REAGENT } \\
\hline 1 & Wash & $5 \mathrm{~mL}$ & Water \\
2 & Elute & $9 \mathrm{Drops}$ & $2 \mathrm{M} \mathrm{NH}_{3}$ (Discarded) \\
& Elute & $12 \mathrm{Drops}$ & $2 \mathrm{M} \mathrm{NH}_{3}$ (Sample) \\
3 & Wash & $3 \mathrm{~mL}$ & $2 \mathrm{M} \mathrm{NH}_{3}$ \\
4 & Wash & $5 \mathrm{~mL}$ & Water \\
5 & Wash & $5 \mathrm{~mL}$ & $2 \mathrm{M} \mathrm{HCl}$ \\
6 & Wash & $5 \mathrm{~mL}$ & Water \\
\hline
\end{tabular}

The separation efficiency of the $15 \mathrm{~mL} \mathrm{XAD}-7$ columns was determined by the liquid-scintillation monttoring of carbon-fourteen-labeled algal protein and algal protein hydrolysate. For triplicate runs at $\mathrm{pH} 2$, $83.2 \pm 0.2 \%$ of the algal proteln and $88.3 \pm 0.3 \%$ of the algal protein hydrolysate were nonretained by the resin. The efficiency of removal of humic substances was determined to be $\geq 99 \%$ by monitoring adsorbance at $420 \mathrm{~nm}, \mathrm{pH} 10$.

The conditions for gas-liquid chromatography are given in Table II. Assay for Humic Carbon. A sample of humic substances had been isolated from the Williamson River by Blunk (1982), and its carbon content analyzed. Various known weights were dissolved in purified water, buffered to $\mathrm{pH} \mathrm{10}$, and the absorbances measured at $420 \mathrm{~nm}$. A linear-regression analysis gave humic carbon as a function of absorbance at $420 \mathrm{~nm}$ (Blunk, 
TABLE II

CONDITIONS FOR GAS-LIQUID CHROMATOGRAPHY

$\begin{array}{ll}\text { Column Temperatures: } & 90^{\circ} \mathrm{C} \text { Initial } \\ & 250^{\circ} \mathrm{C} \text { Final } \\ \text { Programing: } & 5 \mathrm{~min} \text {. Inftial Isothermal Hold } \\ & 2{ }^{\circ} \mathrm{C} / \mathrm{min} . \text { to } 140^{\circ} \mathrm{C} \\ & 4^{\circ} \mathrm{C} / \mathrm{min} . \text { to } 250^{\circ} \mathrm{C} \\ & 275^{\circ} \mathrm{C} \\ \text { Injector Temperature: } & 275^{\circ} \mathrm{C} \\ \text { Detector Temperature: } & 30 \mathrm{~mL} / \mathrm{min} . \\ \text { Carrier Flow (N }): & 1 \mu \mathrm{L} \\ \text { Sample Volume: } & \end{array}$

1982): mg humic carbon $/ \mathrm{L}=\left(61.55 \mathrm{~A}_{420}+0.655\right) / 2$ for a $5 \mathrm{~cm}$ cell. Field samples were collected in LPE bottles and deaerated with prepurifled nitrogen at the sampling sites.

Total Organic Carbon. Totai organic carbon (TOC) analyses were conducted at the Durham Water Treatment Laboratory of the United Sewage Agency, Durham, Oregon. Triplicate determinations were made using a Dohrman Model DC-50 Carbon Analyzer. Field samples were collected in $20 \mathrm{~mL}$ glass bottles and stored at $0^{\circ} \mathrm{C}$.

Iron. Iron was analyzed by AAS on samples with $\mathrm{pH}$ adjusted to $\mathrm{pH} 2$ with $35 \%$ nitric acid. Field samples were collected as for humic carbon. Discharge and Flowrates. Most sample sites were located at river bridges. At such sites, a stream bed profile could be approximately mapped by measuring the vertical distance from the stream bed to a fixed 
reference line. The vertical measurements were made with a 50-foot steel tape with an attached lead welght or with a rigld steel rod. The resulting profile was used to construct a graph of stream crosssectlonal area versus water level, expressed as the vertical distance from the fixed reference line to the water surface. After the initial measurement of stream bed profiles, only the water level was monitored, the cross-sectional area being then estimated graphically. Because some bridges were not level, a reference point was established along the reference line of each bridge for all water level measurements. This same reference point was used for flow rates, which were determined with a General Oceanics 2031 Digital Flowmeter and 2035 Flowneter Readout.

At WR10 and BS10, stream bed profiles were directly measured from water depth measurements at three-foot intervals along a line perpendicular to the stream bed. Water level was directly measured at a reference point. Flow rates at these two sites were determined by measuring the time required for a floating object (orange, stick, pumice, deer droppings, etc.) to travel a distance of thirty feet. At WR32, the stream flows through a large condult which passes beneath road C-676. The water level was measured relative to the top of the conduit and an appropriate fraction of the cross-sectional area of the condult was calculated as the stream bed cross-sectional area. Flow rates were measured as previously described with the digital flowmeter. No water level or flow rate data were obtalned on Klamath Lake (KL10). Derivatization For GLC Analysis. After the volumes were carefully measured, the water samples for the routine monthly survey were acidified to $\mathrm{pH} 2$ with $6 \mathrm{M} \mathrm{HCl}$ and evaporated under a stream of dry, pre- 
purifled $\mathrm{N}_{2}$ at $50^{\circ} \mathrm{C}$ to a final volume of $2 \mathrm{~mL}$. The samples were then quantitatively transferred to 3-mL Reacti-vials and evaporated to $1 \mathrm{~mL}$. An equal volume of $12 \mathrm{M} \mathrm{HCl}$ was added, and the samples were hydrolyzed, under nitrogen, for 22 hours at $110^{\circ} \mathrm{C}$. The hydrolysates were evapurated under a stream of nitrogen at $50^{\circ} \mathrm{C}$ and taken up $1 \mathrm{n} 1 \mathrm{~mL}$ of $0.1 \mathrm{M} \mathrm{HCl}$. They were then desalted on $0.5 \mathrm{~mL}$ columns of Dowex 50W-X4. Five thousand nanograms ( $50 \mu \mathrm{L}$ of a $100 \mathrm{ng} / \mu \mathrm{L}$ stock solution) of gammaaminobutanoic acid (GABA) were added as an internal standard to the $2 \mathrm{M}$ $\mathrm{NH}_{3}$ eluants. The $\mathrm{NH}_{3}$ fractions were evaporated under a stream of nitrogen at $50^{\circ} \mathrm{C}$. Derlvatization was accomplished by the method of Zanetta and Vincendon (1973) with the modification of using acetyl chloride instead of gasous HCl to prepare the acldic alcohols (Felker and Bandursk1, 1975). The basic steps for a run of six samples were as follows: (1) In a separate vial, $0.1 \mathrm{~mL}$ acetyl chloride was mixed with $1.1 \mathrm{~mL}$ methanol; (2) $0.2 \mathrm{~mL}$ acld-methanol was added to each vial, the vials swept with nitrogen and tightly capped, and the samples reacted $10 \mathrm{~min}$. at room temperature; (3) the samples were blown dry at room temperature with nitrogen; (4) In a separate vial, acid-isopentanol was prepared exactly as the acid-methanol; (5) $0.2 \mathrm{~mL}$ acid-isopentanol was added to each vial, the vials swept with nitrogen and tightly capped, and the samples reacted 2 hours at $110^{\circ} \mathrm{C}$; (6) the samples were cooled to room temperature, cantrifuged briefly to remove solvent from the sealing disc, and blown dry at $50^{\circ} \mathrm{C}$ with nitrogen; (7) 0.1 ml acetonftrile was added to each vial, followed by $0.02 \mathrm{~mL}$ heptafluorobutyric anhydride, the vials were swept with nitrogen and tightly capped, and the samples reacted $10 \mathrm{~min}$. at $150^{\circ} \mathrm{C} ;(8)$ the samples were cooled to room 
temperature, spun briefly, and blown dry at $50^{\circ} \mathrm{C}$ with nitrogen;

(9) $0.05 \mathrm{~mL}$ ethyl acetate was added, and the vials tightly capped; (10) samples were run Immediately on GLC. The general form of the derivative is shown at the bottom of Table III.

TABLE III

STANDARD CURVES: ng AMINO ACID VERSUS

AREA AMINO ACID/AREA $50 \mathrm{ng}$ GABA

\begin{tabular}{lrrr} 
Amino Acid & Slope & Intercept & Correlation Coefficient \\
\hline ALA & 54.8 & 0.3 & 0.999 \\
GLY & 50.0 & -0.4 & 0.998 \\
VAL & 58.5 & -1.8 & 0.999 \\
THR & 52.2 & -3.9 & 0.999 \\
SER & 52.4 & -1.6 & 0.984 \\
LEV & 59.4 & -2.8 & 0.997 \\
ILE & 69.5 & -7.5 & 0.993 \\
PRO & 63.2 & -6.2 & 0.988 \\
MET & 90.8 & 2.4 & 0.994 \\
PHE & 41.2 & -5.7 & 0.994 \\
ASP & 58.6 & -4.1 & 0.999 \\
LYS & 75.6 & -2.2 & 0.990 \\
TYR & 61.1 & -1.1 & 0.991 \\
GLU & 61.5 & -4.1 & 0.994 \\
ARG & 192 & -4.5 & 0.977 \\
HIS & 219 & 11 & 0.979 \\
TRP & 232 & 11 & 0.990 \\
& & & \\
\hline
\end{tabular}<smiles>[R]C(NC(=O)C(F)(F)C(F)(F)F)C(=O)OCCC(C)C</smiles> 
Fractionation Study. The steps in the fractionation scheme are outlined in Figure 3. Each of the three river samples was analyzed in triplicate; $100 \mathrm{~mL}$ portions of each sample were analyzed directly for total amino aclds; $1100 \mathrm{~mL}$ portions were flltered through prewashed, $0.45 \mu \mathrm{m}$ filters (M11lipore), and $100 \mathrm{ml}$ of this filtrate was analyzed for dissolved amino acids. Because of irreproduclbility of results on samples eluted off the filters (presumably due to microbial growth on the filters and/or Inability to quantitatively wash amino acids off the filters), particulate amino acids were calculated as the difference between total and dissolved amino acids. The remaining $1000 \mathrm{~mL}$ of filtered sample was actdified to $\mathrm{pH} 1.9$ with $12 \mathrm{M} \mathrm{HCl}$ and passed through a $15 \mathrm{~mL}$ column of XAD-7. The humic substances were eluted with 40-50 mL of $0.1 \mathrm{M}$ NaOH. A portion of the $0.1 \mathrm{M} \mathrm{NaOH}$ eluant was analyzed for humic amino acids. The $1000 \mathrm{~mL}$ of filtered sample that passed through the XAD-7 colum was rotary evaporated to a final volume of $40 \mathrm{~mL}$, desalted on a $1.5 \mathrm{~mL}$ Dowex $50 \mathrm{~W}-\mathrm{X} 4,200 / 400$ column, and split into two equal portions. One portion was analyzed as previously described for free plus protein amino acids. The second portion was derivitized without a preceding hydrolysis step to give free amino acids only. Protein amino acids were calculated to be the difference between free-plus-protein and free amino acids.

Standards. A standard mixture of 17 amino acids was prepared to be $100 \mathrm{ng} / \mu \mathrm{I}$ in each amino acid. Volumes were added to derivatization vials so that injecting $1 \mu \mathrm{L}$ into the GLC would yield 6-80 ng of each amino acid. Each vial was splked with GABA so this same injection volume would yield $50 \mathrm{ng}$ GABA. Triplicate samples at each level of 


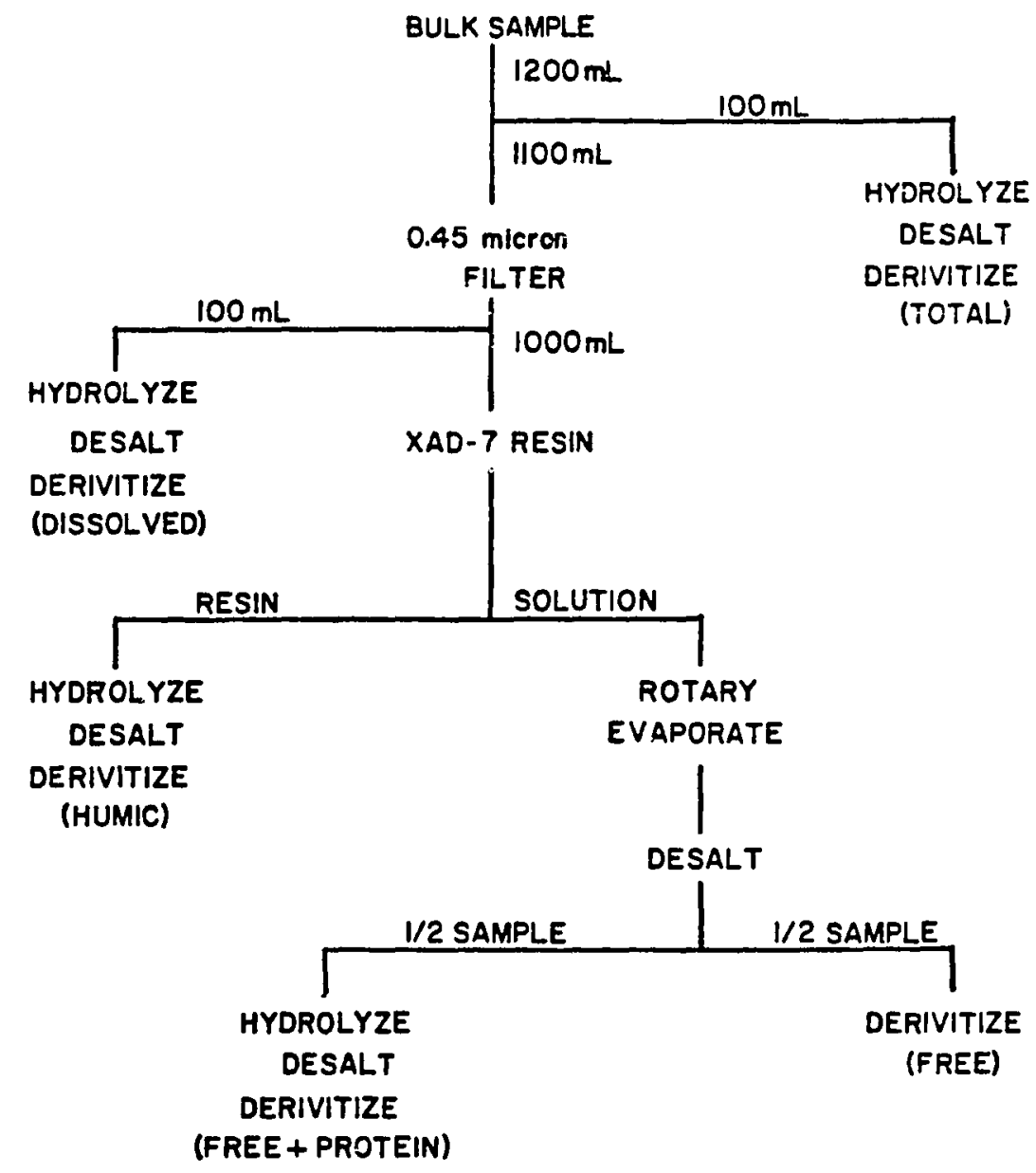

Figure 3. Fractionation Scheme. 
amino actd were run and the data for each amino acid combined in an overall plot of $\mathrm{ng}$ amino acld vs. amino acid area/area of $50 \mathrm{ng}$ GABA. The results are summarized in Table III. Reproducibility in amino acid area/area of $50 \mathrm{ng}$ GABA was $\pm 6 \%$.

The hydrolysis, desalting, and derivatization steps were checked as an entire procedure by analyzing a known proteln, the first 31 residues of raccoon alpha-hemoglobin. The results are summarized in Table IV.

TABLE IV

RACCOON ALPHA-HEMOGLOBIN, FIRST 31 RESIDUES

\begin{tabular}{ccc} 
Amino ACid & Residues Expected & Residues \\
\hline ALA & 5 & 5.0 \\
GLY & 5 & 4.8 \\
VAL & 1 & 1.0 \\
THR & 1 & 1.3 \\
SER & 1 & 1.3 \\
LEV & 2 & 2.0 \\
ILE & 2 & 1.5 \\
PRO & 1 & 1.2 \\
MET & 0 & 0 \\
PHE & 0 & 0 \\
ASP & 3 & 3.1 \\
LYS & 3 & 2.2 \\
TYR & 1 & 0 \\
GLU & 3 & 3.1 \\
ARG & 1 & 0.5 \\
HIS & 1 & 0.7 \\
TRP & 1 & $* *$ \\
& & \\
\hline
\end{tabular}

* Relative to ALA = 5, average of two analyses. **TRP is lost during acid hydrolysis.

Methods for Complexation Capacity Study

Isolation of Williamson River Humic Substances. Twelve, fivegallon polyethylene carboys were filled with water from WR-50. After belng transported to the lab, each carboy was deaerated 15 min. with 
prepurifled nitrogen and then stored at $5^{\circ} \mathrm{C}$. Four carboys, in turn, were centrifuged with the continuous flow system at 10K RPM at a flow rate of about $150 \mathrm{~mL} / \mathrm{mln}$. , acldified to $\mathrm{pH} 2$ by the addition of $12 \mathrm{M} \mathrm{HCl}$, and applied to a $6.7 \mathrm{~L}$ column of XAD-7 resin. The humic substances were eluted with $1300 \mathrm{~mL} 0.15 \mathrm{M}$ triethylamine, which was rotary evaporated at $30^{\circ} \mathrm{C}$ to a final volume of about $250 \mathrm{~mL}$. This process was repeated twice, the evaporated column eluants pooled, and the volume brought to 4 liters by the addition of purified water. Triethylamine was used as the eluting base because, unlike sodium hydroxide, it is volatilized off during rotary evaporation. The 4 liters of solution were passed through a $400 \mathrm{~mL}$ column of Amberlite IR-120 (Rohm and Haas) in the hydrogen form. The prior dilution was necessary to prevent the precipitation of humic acid as the $\mathrm{pH}$ drops as hydrogen fon on the column is displaced. The desalted humics solution was rotary evaporated at $30^{\circ} \mathrm{C}$ to a final volume of $470 \mathrm{~mL}$. Th1s solution was freeze-dried, and the final product weighed. The original sixty gallons of river water yielded $4.8 \mathrm{~g}$ 1solated humic materials. An elemental analysis was done on the freeze drled product (Hedges, 1982): $48.3 \% \mathrm{C}, 3.86 \% \mathrm{H}, 1.96 \% \mathrm{~N}, 4.76 \%$ ash. Complexation Capactty Titrations. All complexation capacity experiments were carried out at $25.0^{\circ} \mathrm{C}$ in the constant temperature titration system previously described. The AIM-65 microprocessor was Interfaced to the Hewlett-Packard multimeter and the Gilmont buret. The course of each titration was under the control of the microprocessor, ut1lizing the program HATIT. Basically, the program is in two parts. The flrst part accepts any number of metal ion standards, the concentration of each belng keyboard entered. The program then reads the 
voltages from the multimeter after a user-set delay time. A reading is taken every five seconds until at least 10 successive readings agree within a user-set range, here $\pm 0.2 \mathrm{mV}$. The average of the ten voltage readings is computed and entered for that particular standard. The program then computes a standard linear least squares analysis of the data and prints the results. The second part of the program drives a motorized precision buret to deliver titrant to the titration vessel. The number of titration points, delay time, and volume increment between each point is keyboard entered. Voltage readings are taken as before for the standards. At the end, the program will do selected calculations on the raw data, based on the standardization. A listing of HATIT is given in Appendix A.

The accuracy and reproducibility of the motor-driven buret was examined. For increments of $20 \mu \mathrm{L}$ (the same size increment used in this study), the motor drive is accurate to $\pm 0.4 \mu \mathrm{L}$ (Iliaifar, 1982).

Standards for the complexation capacity study ranged from $10^{-3} \mathrm{M}$ to $10^{-6} \mathrm{M}$ total copper in $0.1 \mathrm{M} \mathrm{NaClO}_{4}$ at $\mathrm{pH} \mathrm{4.5.} \mathrm{For} \mathrm{the} \mathrm{triplicate}$ titrations at $\mathrm{pH} 5.0,5.5$, and $6.0,0.1000 \mathrm{M}$ copper titrant was added in 20 increments of $20 \mu \mathrm{L}$ each, and the humus solutions were $38.2 \mathrm{mg} \mathrm{C} / \mathrm{L}$. For the triplicate titrations at $\mathrm{pH} 6.5,0.01000 \mathrm{M}$ copper titrant was added in 20 increments of $20 \mu \mathrm{L}$ each to a $3.82 \mathrm{mg} \mathrm{C} / \mathrm{L}$ humus solution. The $\mathrm{pH}$ was monitored and adjusted with $2-4 \mu \mathrm{L}$ aliquots of $0.1 \mathrm{M} \mathrm{NaOH}$.

The raw data were plotted as complexed metal versus total metal and fitted with a simplex program, SMPLX, to the equation

$$
Y=A[1-\exp (B X)]
$$

where $\mathrm{Y}=$ complexed metal and $\mathrm{X}=$ total metal. The parameter $\mathrm{A}$ 
represents the limiting value of $Y$ as $X$ approaches infinity. A listing and description of SMPLX is given in Appendix B.

Methods for Copper-Humic Substances Stability Function Study

Determination of Copper-Oxalate Constants. Since the ISE cannot measure copper fon at the levels found in natural waters, it was decided to attempt humic subtaices titrations into copper, metal-ion buffers. Oxalic actd was chosen because, as sodium oxalate, it can be obtained in primary standard purity and because 1t's reported binding constants for copper $\left(\log \mathrm{K}_{1}=4-6, \log \mathrm{K}_{2}=3-5\right)$ fall into a range expected for copper-humic substances (Sillen and Martell, 1964). To determine a best value for the two binding constants for the $\mathrm{Cu}(\mathrm{OX})$ and $\mathrm{Cu}(\mathrm{OX})_{2}$ species, three sets of titrations were done in triplicate at $\mathrm{pH}$ 6.0. All titrations were done in the constant temperature system at $25.01^{\circ} \mathrm{C}$ and under microprocessor control using the program HATIT, both previously described. Standards for the titrations ranged from $10^{-3} \mathrm{M}$ to $10^{-6} \mathrm{M}$ copper in $0.1 \mathrm{M} \mathrm{NaClO}_{4}$ at $\mathrm{pH}$ 4.5. For the $10^{-3} \mathrm{M}$ oxalate solution in $0.1 \mathrm{M} \mathrm{NaClO}_{4}, 0.1000 \mathrm{M}$ copper titrant was added so that total copper ranged from $10^{-5} \mathrm{M}$ to $10^{-3} \mathrm{M}$. For the $10^{-4}$ and $10^{-5} \mathrm{M}$ oxalate solutions in $0.1 \mathrm{M} \mathrm{NaClO}_{4}, 0.01000 \mathrm{M}$ ccpper titrant was added so that total copper ranged from $10^{-6}$ to $10^{-4} \mathrm{M}$. The free metal ion data were $\mathrm{fit}_{\text {on }}$ the simplex program, SMPLX. Since free oxalate concentration is not known, it was calculated from the ligand mass balance quadratic equation using an initial guess for $K_{1}$ and $K_{2}$ :

$$
\left[(M) 2 K_{2}\right](L)^{2}+\left[1+K_{a 1}(H)+K_{a 2}(H)^{2}+K_{1}(M)+K_{4}(M)(H)\right](L)-L_{T}=0
$$


where (M) is the experimental free metal fon concentration, (L) is free oxalate concentration, $\mathrm{L}_{\mathrm{T}}$ is total oxalate concentration, (H) is hydrogen Ion concentration, $\mathrm{K}_{\mathrm{a} 1}$ and $\mathrm{K}_{\mathrm{a} 2}$ are the proton binding constants for oxalic acid, and $\mathrm{K}_{4}$ is the binding constant for the species CuHox. The ligand value thus calculated is then put into the metal mass balance equation (Equation 3), which is fitted for best values of $k_{1}$ and $k_{2}$. The new $K_{1}$ and $K_{2}$ are put into Equation 2, which is re-solved for ( $L$ ). The process is repeated until the change in successive values of $k_{1}$ and $\mathrm{K}_{2}$ is less than a user-selected value.

$$
\text { (M) }\left[1+K_{1}(L)+K_{2}(L)^{2}+K_{4}(H)(L)+K_{3}(O H)\right]-M_{T}=0
$$

where $M_{T}$ is the total metal concentration and $K_{3}$ is the binding constant for the species $\mathrm{Cu}(\mathrm{OH})^{+}$.

Feasibility of the Metal-Ion Buffer Systerie It is known that the presence of a metal-buffering ligand in excess of total metal concentration can extend the working range of the ISE many orders of magnitude below its normal operating $11 \mathrm{mlt}$, as long as total metal is within the linear range of the ISE In an unbuffered solution (Blaedel and Dinwiddle, 1974). A set of copper standards in $0.1 \mathrm{M} \mathrm{NaClO}_{4}, \mathrm{pH} 4.5$ were prepared from $10^{-3} \mathrm{M}$ to $10^{-8} \mathrm{M}$ and analyzed in the constant temperature system to determine the feasible lower limit of linear response. The $0.1000 \mathrm{M}$ oxalate was titrated in duplicate into $10^{-6}$ and $10^{-7} \mathrm{M}$ total copper solutions at $\mathrm{pH}$ 5.0. The free copper concentration found was compared to that calculated for the system using the program MLEQL. MLEQL, based on the calculation methods used in the Fortran program MINEQL (Westall et al., 1976), is a program written for the Tektronix Model 31 desktop computer that will calculate the equilibrium 
concentrations for all species in a system of a single metal, a single ligand of interest, and four metal-hydroxy complexes.

Humic Substances Titrations into a Copper, Metal-Ion Buffer. To determine the amounts of copper and humic substances necessary to duplicate the DOM: copper ratio at the most humus-rich site on the river, WR-50, total copper was determined by quadruplicate graphite furnance AAS analysis of acidified river water samples. The amount of humic substances in $\mathrm{mg} \mathrm{C} / \mathrm{L}$ was estimated from absorbance measurements (Perdue et al., 1981), converted to eq copper/L via the complexation capacity measurements done for this research, and corrected by subtracting the equivalents of iron found in each sample (Perdue et a1., 1981). The ratio of DOM:copper was then calculated for each of sixteen sampling dates for WR-50, and these results averaged.

All titrations to determine the copper-humic substances binding function were carried out at $25.01^{\circ} \mathrm{C}$ in the constant temperature system and under microprocessor control using the program HATIT, both previously described.

Duplicate titrations were done at $\mathrm{pH} 5.0,5.5,6.0$, and 6.5 , to match the complexation capacity studies done earlier. Because the metalion buffer solution to be titrated would be the same in all cases except for $\mathrm{pH}$, it was made in a single, $2 \mathrm{~L}$ batch to be $10^{-5} \mathrm{M}$ in oxalate, $10^{-7} \mathrm{M}$ in total copper, and $0.1 \mathrm{M}$ in $\mathrm{NaClO}_{4}$. In all cases, the 4500 $\mathrm{mg} \mathrm{C} / \mathrm{L}$ humic substances solution was added in 50 increments of $0.050 \mathrm{~mL}$ each. The $\mathrm{pH}$ was monitored and adjusted with $2-4 \mu \mathrm{L}$ aliquots of $0.1 \mathrm{M}$ $\mathrm{NaOH}$. 
CHEMICAL EQUILIBRIA IN MULTILIGAND MIXTURES

The fact that metal complexation by humic substances results in the release of protons indicates that, to some extent, the same ligands are involved in proton and metal binding. While proton binding can be studied in the absence of competitive metal binding in metal-free solutions, metal complexation must inevitably be studied in competition with proton binding. It is therefore highly advantageous to use conditional stability constants to describe metal binding at constant pH. In the following equations, all charges are omitted and only 1:1 metalligand complexes are explicity considered. For complexation of a metal, $M$, by the $i^{\text {th }}$ deprotonated ligand or binding site in a multiligand mixture at constant $\mathrm{pH}$,

$$
M+L_{i} \rightleftharpoons M_{i}
$$

and

$$
K_{i}=\frac{\left[M L_{i}\right]}{[M]\left[L_{i}\right]}
$$

It is more convenient to define a conditional stability constant

$$
k_{i}^{\prime}=\frac{\left[M L_{i}\right]}{[M]\left[H_{x_{i}} L_{i}\right]}=k_{i}\left(\frac{\left[L_{i}\right]}{\left[H_{x_{i}} L_{i}\right]}\right)
$$


where $\left[\mathrm{H}_{\mathrm{X}_{1}} \mathrm{~L}_{1}\right]$ is the concentration of all forms of the $1^{\text {th }}$ ligand that are not bound to $M$. The conditional stability constant, $K_{1}^{\prime}$, is thus equal to the thermodynamic stability constant, $K_{1}$, times the fraction of $\mathrm{H}_{\mathrm{X}_{1}} \mathrm{~L}_{1}$ that is not protonated. This fraction is constant at constant $\mathrm{pH}$.

In a complex multiligand mixture, both an average stability "constant", $\overline{\mathrm{k}}$, and a conditional average stability "constant", $\overline{\mathrm{k}}$, can be defined, the latter belng readily calculated from experimental data.

$$
\begin{gathered}
\bar{K}=\frac{\sum_{i}\left[M L_{i}\right]}{[M] \sum_{i}\left[L_{i}\right]}=\frac{\sum_{i} K_{i}\left[L_{i}\right]}{\sum_{i}\left[L_{i}\right]} \\
\bar{K}^{\prime}=\frac{\sum_{i}^{\left[M L_{i}\right]}}{[M] \sum_{i}\left[H_{X_{i}} L_{i}\right]}=\frac{\sum_{i}^{\sum_{i}\left[H_{X_{i}} L_{i}\right]}}{\sum_{i}\left[H_{X_{i}} L_{i}\right]}=\frac{\left(C_{M}-[M]\right)}{[M]\left(C_{L}-C_{M}+[M]\right)}
\end{gathered}
$$

where $C_{I}$ is the stoichimoetric concentration of Iigand and $C_{M}$ is total metal minus hydroxy complexes. Dividing the numerator and denominator of Eq. 8 by the concentration of all uncomplexed forms of an arbitrarily selected reference ligand $\left[\mathrm{H}_{\mathrm{X}_{\mathbf{r}}} \mathrm{L}_{\mathrm{r}}\right], \mathrm{Eq} \cdot 9$ is obtained.

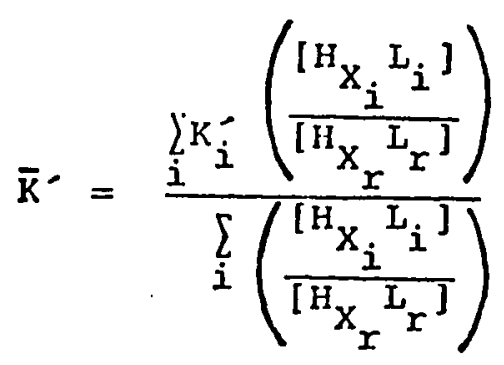


This particular form for $\overline{\mathrm{k}}^{\prime}$ is introduced here to more amply 11lustrate the fact that $\overline{\mathrm{k}}^{\prime}$ is not a constant, but rather a function whose value changes continuously as metal is added to a multiligand mixture. For purposes of discussion let us assume that $\mathrm{H}_{\mathrm{X}_{\mathbf{r}}} \mathrm{L}_{\mathbf{r}}$ is the weakest metalbinding ligand in the mixture. Consider then the behavior of $\vec{k}^{\prime}$ as metal tons are added to this ligand mixture. The form of $\bar{K}^{\prime}$ is that of a weighted average. The welghting factor $\left(\left[\mathrm{H}_{\mathrm{X}_{1}} \mathrm{~L}_{1}\right] /\left[\mathrm{H}_{\mathrm{X}_{\mathrm{r}}} \mathrm{L}_{\mathbf{r}}\right]\right)$ of the IIgand with the largest $K_{i}^{\prime}$ value will be greatest at the lowest levels of added metal and will decrease steadily as $C_{M}$ increases. The Inevitable result is that $\overline{\mathrm{K}}^{\prime}$ must decrease as $C_{M}$ increases and cannot be regarded as a constant at all. The functional nature of $\ddot{K}^{\prime}$ has been clearly recognized by previous researchers (MacCarthy and Smith, 1979; Gamble et al., 1980).

For reasons that will become more apparent later, it is useful to examine the general equilibrium description of a multiligand mixture that contains two distinct classes of ligands (classes I and II). In this case, equations analogous to Eq. 8 can be derived for each class of ligands.

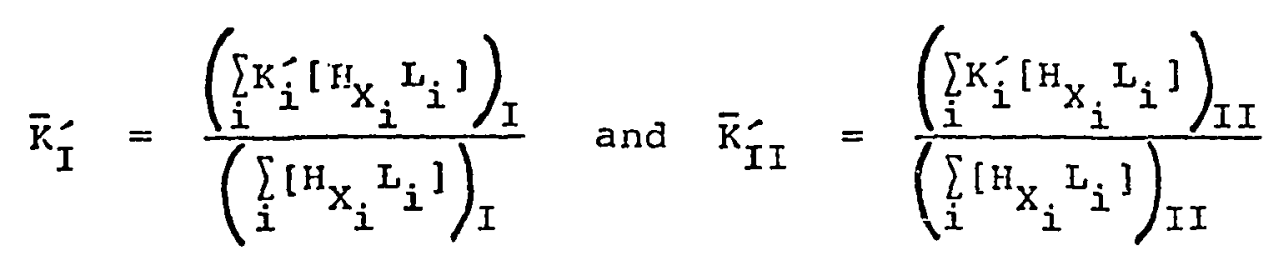

Unfortunately, only the overall $\overline{\mathrm{k}}^{\prime}$ given by Eq. 8 can be calculated from experimental data. The experimental $\overline{\mathrm{K}}^{\prime}$ is a welghted average of $\overline{\mathrm{K}}_{\mathrm{I}}^{\prime}$ and $\overline{\mathrm{K}}_{\mathrm{II}}^{0}$. 


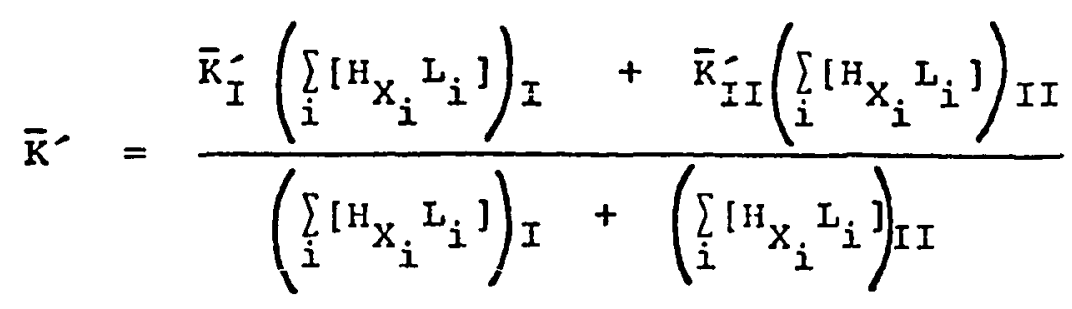

More importantly, it must be recognized that, like $\overline{\mathrm{K}}^{\prime}, \overrightarrow{\mathrm{K}}_{\mathrm{I}}^{\prime}$ and $\overline{\mathrm{K}}_{\mathrm{II}}^{\prime}$ are functions that change continuously as the ligands within each class react sequentially with added metal. Any type of average stability "constant" will have a fixed value only at a single $C_{M}$ value during the titration of metal into a multiligand mixture.

The third general subject is the treatment of complexes with other than 1:1 stoichiometry. Th1s subject has been rigorously examined by MacCarthy and coworkers (MacCarthy, 1977; MacCarthy and Smith, 1979). The conclusions reached above with regard to $1: 1$ metal-1igand complexes also apply to other possible stofchiometries. Thus, while average "constants" for $1: 1$ and $1: 2$ complexes can be defined mathematically, those "constants" will change continuously as metal is added to a multi11gand mixture.

\section{DISCRETE MULTILIGAND MODELS}

Multiligand models or the analogous multiple binding site models usually assume $1: 1$ stoichiometry for all metal-1igand complexes. It is convenient to combine Eq. 6 with the ligand mass balance equation for the $1^{\text {th }}$ ligand or binding site,

$$
c_{i}=\left[\mathrm{H}_{x_{i}} \mathrm{~L}_{i}\right]+\left[M L_{i}\right]
$$


where $C_{i}$ is the stoichiometric concentration of the $i^{\text {th }}$ ligand or binding site, to obtain

$$
v_{i} \equiv\left[M L_{i}\right] / C_{i}=\left(\frac{K_{i}^{\prime}[M]}{1+K_{i}^{\prime}[M]}\right)
$$

When summed for all ligands, Eq. 14 is obtained.

$$
\bar{v} \equiv \frac{\sum_{i} v_{i} c_{i}}{\sum_{i} c_{i}}=\sum_{i}\left(\frac{k_{i}^{[}[M]}{1+k_{i}^{\prime}[M]}\right)\left(\frac{c_{i}}{c_{L}}\right)=\frac{c_{M}-[M]}{c_{I}}
$$

Experimental $\bar{v}$ values, calculable from $C_{M}, C_{L}$, and $[M]$ via Eq. 14, can be used to calculate $k$.

$$
\bar{K}^{-}=\frac{1}{[M]}\left(\frac{\bar{v}}{1-\bar{v}}\right)
$$

As Indicated previously, $\overline{\mathrm{K}}^{\prime}$ values are not constant in multiligand mixtures. The only real constants in such systems are the $\mathrm{K}_{i}^{\prime}$ values of the individual ligands or binding sites, and then only at constant $\mathrm{pH}$. There is no direct method by which those $K_{1}^{\prime}$ values can be extracted from experimental $\bar{k}^{\prime}$ values for multiligand mixtures such as humic substances, simply because there are potentially so many different metal binding groups to be characterized.

In several recent studies of metal complexation by humic substances (Mantoura and Riley, 1975; Guy and Chakrabarti, 1976; Bresnahan et al., 1978; Sposito et al., 1979; Hirata, 1981; Sohn and Hughes, 1981; 
Sposito, 1981; McKnight et al., 1982), a serious conceptual error has resulted from attempts to use the Scatchard equation (Scatchard, 1949; Scatchard et a1., 1957) or other related equations to extract equilibrium constants and ligand concentrations from experimental data. In those studies, it $1 s^{\circ}$ assumed that the $k_{1}^{\prime}$ values for discrete, Individual ligands in Eq. I 4 can alternatively be assumed to represent average stability constants for distinct classes of 11gands. The mathematical fallacy in this assumption is best illustrated by examining the pertinent equations.

The first term of Eq. 14

$$
\bar{v}=\left(\frac{K_{I}(M)}{1+K_{I}(M)}\right)\left(\begin{array}{l}
c_{I} \\
\frac{c_{L}}{1}
\end{array}\right)
$$

is easily rearranged to yleld the one-component Scatchard equation Eq. (17).

$$
\frac{\bar{v}}{(M)}=k_{I}\left(\frac{C_{I}}{C_{I}}\right)-k_{1} \bar{v}
$$

This simple equation, which predicts a linear relationship between $\bar{v} /(M)$ and $\bar{v}$, never adequately describes the curvilinear plots of $\bar{v} /(M)$ versus $\bar{v}$ that are obtained in studies of metal-humus complexation equilibria. Almost without exception, those researchers who use the Scatchard equation to analyze experimental data respond to the failure of the linear one-component model (Eq. 17) by including the second term from Eq. 14, ylelding 


$$
\bar{v}=\left(\frac{K_{1}(M)}{1+K_{1}(M)}\right)\left(\frac{c_{1}}{c_{L}}\right)+\left(\frac{K_{2}(M)}{1+K_{2}(M)}\right)\left(\frac{c_{2}}{c_{L}}\right)
$$

The addition of the second term (which increases the number of curvefitting parameters from two to four) generally results in a greatly improved fit of the experimental data, leading to the conclusion that humfc substances contain two "classes" of metal complexing ligands. It should be noted that Mcknight and co-workers (McKnight et al., 1982), were unable to fit their data for one type of aquatic humis to a twocomponent model and added a third term to Eq. 18. The curve-fitting constants $\mathrm{K}_{1}, \mathrm{C}_{1} / \mathrm{C}_{\mathrm{L}}, \mathrm{K}_{2}$, and $\mathrm{C}_{2} / \mathrm{C}_{\mathrm{L}}$ are treated as average stability constants and 1igand concentrations for the two presumed classes of ligands. The best values of $k_{1}, C_{1} / C_{L}, K_{2}$, and $C_{2} / C_{L}$ are necessarily obtained by curve-fitting experlemental data over a range of $\bar{v}$ values. So $C_{M}$ and/or $C_{L}$ are varied considerably, usually by titration of metal Into a humus solution, to generate the data set. In the previous discussion, the functional nature of average stability "constants" was demonstrated. Even if humic substances did contain two distinct classes of ligands, $\overline{\mathrm{K}}_{\mathrm{I}}^{\prime}$ and $\overline{\mathrm{K}}_{\mathrm{II}}^{\prime}$ would vary continuously during a titration. Thus, $\overline{\mathrm{K}}_{\mathrm{I}}^{\prime}$ and $\overline{\mathrm{K}}_{\mathrm{II}}^{\prime}$ cannot be equated with $\mathrm{K}_{1}$ and $\mathrm{K}_{2}$, both of which are Implicitly assumed to be independent of $C_{L}$ and $C_{M}$ In Eq. 18. The whole Idea of extracting average stability constants from Eq. 18 is clearly erroneous. The four constants that are obtained from the two-component Scatchard equation must therefore be regarded as empirical curve-fitting parameters with no chemical significance. 
The conclusions given in the preceding paragraph are not intended as a critizism of the Scatchard equation per se, but rather the erroneous assumption that $K_{i}^{\prime}$ could represent a class of related ligands rather than one discrete 1igand. The Scatchard equation has been wide1y and successfully applied to biomolecules such as protelns and nucleic acids. It is not at all unreasonable to expect that a purifled protein molecule might have only one or two distinct sites for binding of a metal Ion or other substrate.

The same conceptual error has also been made in studies where other types of equations have been used to analyze experimental data. For example, if Eq. 16 is 1nverted and rearranged, Eq. 19 is obtained.

$$
\frac{1}{\bar{v}}=\left(\frac{C_{I}}{C_{1}}\right)+\left(\frac{C_{L}}{C_{1}}\right)\left(\frac{I}{K_{I}(M)}\right)
$$

By plotting $1 / \bar{v}$ versus $1 /(M), C_{1} / C_{L}$ and $K_{1}$ can be obtained for a system that contains only one discrete 11gand. This equation has been in use for as long as the Scatchard equation for describing equilibria in blochemical systems (Karush and Sonenberg, 1949). More recent1y, Eq. 19 has been used by Bufflé and co-workers (Bufflé et al., 1977) in an attempt to describe metal binding by humic substances, with the erroneous assumption that $k_{1}$ could represent the average stability constant $\left(\overline{\mathrm{K}}_{\mathrm{I}}^{\prime}\right)$ for a class of ligands. In this case, the fallure of Eq. 19 to describe metal complexation by humic substances was attributed to the formation of both $1: 1$ and 1:2 metal-ligand complexes. The addition of an additional curve-fitting parameter (the average stablifty constant 
for $1: 2$ complexes) resulted in a greatly improved fit of the experimental data. As in the case of the two-component Scatchard equation, however, the curve-fitting parameters of the two-stolchiometry model are simply empirical constants. While 1 t is indeed possible that $1: 1$ and $1: 2$ complexes are formed, it is not possible to determine the relevant average equilibrium constants because those "constants" change continuously as $C_{L}$ and/or $C_{M}$ are changed.

In further work, Bufflé and co-workers (Bufflé et al., 1980) found that their two-stolchiometry model would not fit their data. After ruling out the possibility of polynuclear complexes with humus and copper hydrolysis products because of experimental conditions, they first added a third set of terms to Eq. 19 to account for a proposed copper binding to a humus aggregate:

$$
M+L_{n}=M\left(L_{n}\right)
$$

where $n$ is arbitarily $\leq 2$. While the expanded model enhanced the data fit, the authors admitted that "the errors incurred in the calculated constants become so large that it is difficult to tell whether or not they have any significance" (Bufflé et al., 1980). When work done at various levels of $C_{L}$ gave data that could not all be fit with the same three-component equation, a forth reaction was proposed, involving mixed ligand complexes, (Bufflé et al., 1980):

$$
\mathrm{M}+\mathrm{HXL}+\mathrm{A}=\mathrm{MLA}+\mathrm{XH}^{+}
$$

where $A$ is an unspecifled Inorganic 11gand. Data were presented to show that the MLA binding constant can be reasonably estimated as the product 
of the binding constants for ML and MA.

The end result was a model involving the equilibrium binding expressions for four species: $M L, M(L)_{2}, M\left(L_{2}\right)$, and MLA. Below $30 \mathrm{mg}$ humus/L, only $M L, M(L)_{2}$, and MLA were considered. Above $30 \mathrm{mg}$ humus/L, $M L, M(L)_{2}, M L A$, and $M\left(L_{2}\right)$ were considered. In both cases, the rationale for the existance of the extra species was the fallure of the original, two-component model, not rigorous knowledge of the chemical system. The possible artificiality of this approach was recognized at the time when the authors, in a discussion of the proposed $M\left(L_{2}\right)$ species, admitted that their method "does not allow these $\left[M\left(L_{n}\right)\right]$ complexes and the classical $\mathrm{MI}_{\mathfrak{n}}$ complexes to be distinguished" (Bufflé et al., 1980). The discussion in the preceding paragraphs may have given the Impression that there is no rigorous method by which metal complexation by humlc substances can be effictently described. However, MacCarthy and Smith (1979) have shown that, under severly limiting conditions of excess ligand that may not be attainable in laboratory studies or in the environment, the average stability "constants" for $1: 1,1: 2$, and higher complexes in multiligand systems approach constant limiting values. While this conclusion is of theoretical interest, it is of 1ittle practical importance, given the analytically imposed limitations on $C_{M}$ and $\mathrm{C}_{\mathrm{L}}$ values in laboratory studies.

CONTINUOUS MULTILIGAND MODELS

The most rigorous method for describing proton and metal binding by humic substances has been developed by Gamble and co-workers (Gamble, 1970, 1972; Burch et al.: 1978; Gamble et al., 1980), who have clearly 
recognized the functional nature of $\vec{k}^{\prime}$ values. They have suggested that humic substances contain a continuous distribution of non-identical functional groups that can bind protons or metal ions. Even when they have subdivided proton binding sites into two classes, the $\overrightarrow{\mathrm{K}}_{\mathrm{I}}^{\prime}$ and $\overline{\mathrm{K}}_{\mathrm{II}}^{\prime}$ values have been consistently treated as functions rather than constants. In some Instances, they have used polynomial equations to empirically describe the variation of $\overrightarrow{\mathrm{K}}^{\prime}$ values with solution composition. While Gamble and co-workers have not calculated discrete $K_{i}^{\prime}$ values from experimental data, they have demonstrated that the instantaneous $\overline{\mathrm{K}}^{\prime}$ values for the group which is reacting at a particular set of $C_{L}$ and $C_{M}$ values can be estimated mathematically by partial differentiation of appropriate polynomial equations.

The principal objection to the rigorous treatment proposed by Gamble is probably more psychological than technical. There is no efficlent method for describing the variation of $\overline{\mathrm{K}}^{\prime}$ with solution composition, so the $\vec{k}^{\prime}$ results must be either tabulated or presented graphically. A simple set of constants that could be used to reconstruct the data set is not obtainable by Gamble's method.

Posner (1964, 1966) showed that proton binding by humfc substances was efficiently described by a continuous multiligand distribution model, the relative concentration of each discrete ligand being normally distributed relative to the $\mathrm{pK}_{i}$ of the ligand. In a normal distribution of ligands,

$$
\frac{c_{i}}{c_{I}}=\frac{1}{\sigma \sqrt{2 \pi}} \exp \left[-\frac{1}{2}\left(\frac{\mu-\mathrm{pk}_{i}}{\sigma}\right)^{2}\right] \mathrm{dpK}
$$


where $C_{i} / C_{L}$ is the mole fraction of Iigands in the interval dpK whose acid dissociation constant is expressed as a negative logarithm ( $\mathrm{pK}_{1}$ ), and $\sigma$ is the standard deviation for the distribution of $\mathrm{pK}_{1}$ values about the mean $\mathrm{pK}$ values $(\mu)$ for the mixture of ligands. Similar models have been used to describe the binding of anfons to proteins (Karush and Sonenberg, 1949) and the adsorption of gases on catalytic surfaces (Sips, 1948). Th1s general approach setms to be an excellent alternative to Gamble's method in that an entire titration curve can be sumarized by the $\mu$ and $\sigma$ values for the multiligand mixture. The somewhat objectionable procedure of assuming a normal distribution can be overcome by the use of more sophisticated statistical methods that actually determine the shape of the best ligand distribution curve from experimental data (Parrish, 1982).

For this research, only the normal distribution model will be examined. This distribution model is easily combined with Eq. 14 to yield:

$$
\bar{v}_{\text {calc }}=\frac{1}{\sigma \sqrt{2 \pi}} \int_{-\infty}^{\infty}\left(\frac{[M] 10^{\log K^{-}}}{1+[M]\left(10^{\log K^{-}}\right)}\right) \exp \left[-\frac{1}{2}\left(\frac{\mu-\log K^{-}}{\sigma}\right)^{2}\right] d \log K^{-}
$$

Numerical methods (e.g., Gaussian quadrature, Simpson's method) can be used to evaluate the Integral in Eq. 23 for any values of [M], given a set of $\mu$ and $\sigma$ values. Given a set of experimental $\bar{v}$ and [M] values, nonlinear regression techniques can be used to determine the best values of $\mu$ and $\sigma$ for the set of data. Either $\bar{v}$ or corresponding $\log \overline{\mathrm{K}}^{\prime}$ values can be used for regression.

In proton binding by humic substances, both carboxylic acid and 
phenol functional groups must be considered. Likewise, the possibility of two classes of metal binding ligands should be considered. Accordingly, a bimodal normal distribution model will be used in some of the applications that follow. The extension from Eq. 23 to a bimodal model is easily accomplished. Equations that are analogous to Eq. 23 can be written for $\bar{v}_{I}\left(g i v e n \mu_{I}\right.$ and $\sigma_{I}$ ) and for $\bar{v}_{I I}$ (given $\mu_{I I}$ and $\left.\sigma_{I I}\right)$. Then for $C_{L}=\left(C_{I}+C_{I I}\right)$, where $C_{I}$ and $C_{I I}$ are stoichiometric concentrations of two classes of ligands (e.g., carboxyl and phenolic groups),

$$
\bar{v}=\theta \bar{v}_{I}+(I-\theta) \bar{v}_{I I}
$$

where $\theta=c_{I} / C_{L}$ and $(1-\theta)=c_{I I} / C_{L}$. The bimodal distribution model thus has five curve-fitting parameters $\left(\theta, \mu_{I}, \sigma_{I}, \mu_{I I}\right.$, and $\left.\sigma_{I I}\right)$ that must be determined by nonlinear regression. 
CHAPTER IV

\section{RESULTS AND DISCUSSIONS}

Amino Acid Study

As shown in Figure 4, 15 major amino acids were separated. Asparagine and aspartic acid yield a single peak, as do glutamine and glutamic acld. On a few occassions when total amino acids were above $10 \mu \mathrm{M}$, other amino acids gave separate but very small peaks. These included $\beta-A L A, H Y P, O R N$, and TYR.

The results for Individual amino acids at each sampling site for the two-year study are given in Appendix D. The mole percentages of the Individual amino acids, averaged over all of the sampling sites, are given in Table $\mathrm{V}$.

\section{TABLE V}

MOLE PERCENT OF TOTAL AMINO ACIDS IN THE

WILLIAMSON RIVER, AVERAGED OVER TWO YEARS

\begin{tabular}{lr} 
Amino Acid & Mole \% \\
\hline Giycine & 18.7 \\
Aspaxtic acid & 13.6 \\
Alanine & 11.8 \\
Glutamic acid & 9.6 \\
Serine & 9.5 \\
Threonine & 6.1 \\
Phenylalanine & 5.2 \\
Valine & 4.7 \\
\hline
\end{tabular}

\begin{tabular}{lc} 
Amino Acid & Mole \% \\
\hline Leucine & 4.7 \\
Methlonine & 3.6 \\
Proline & 3.5 \\
Lysine & 3.0 \\
Isoleucine & 2.3 \\
Histidine & 2.2 \\
Arginine & 1.2 \\
& \\
\hline
\end{tabular}




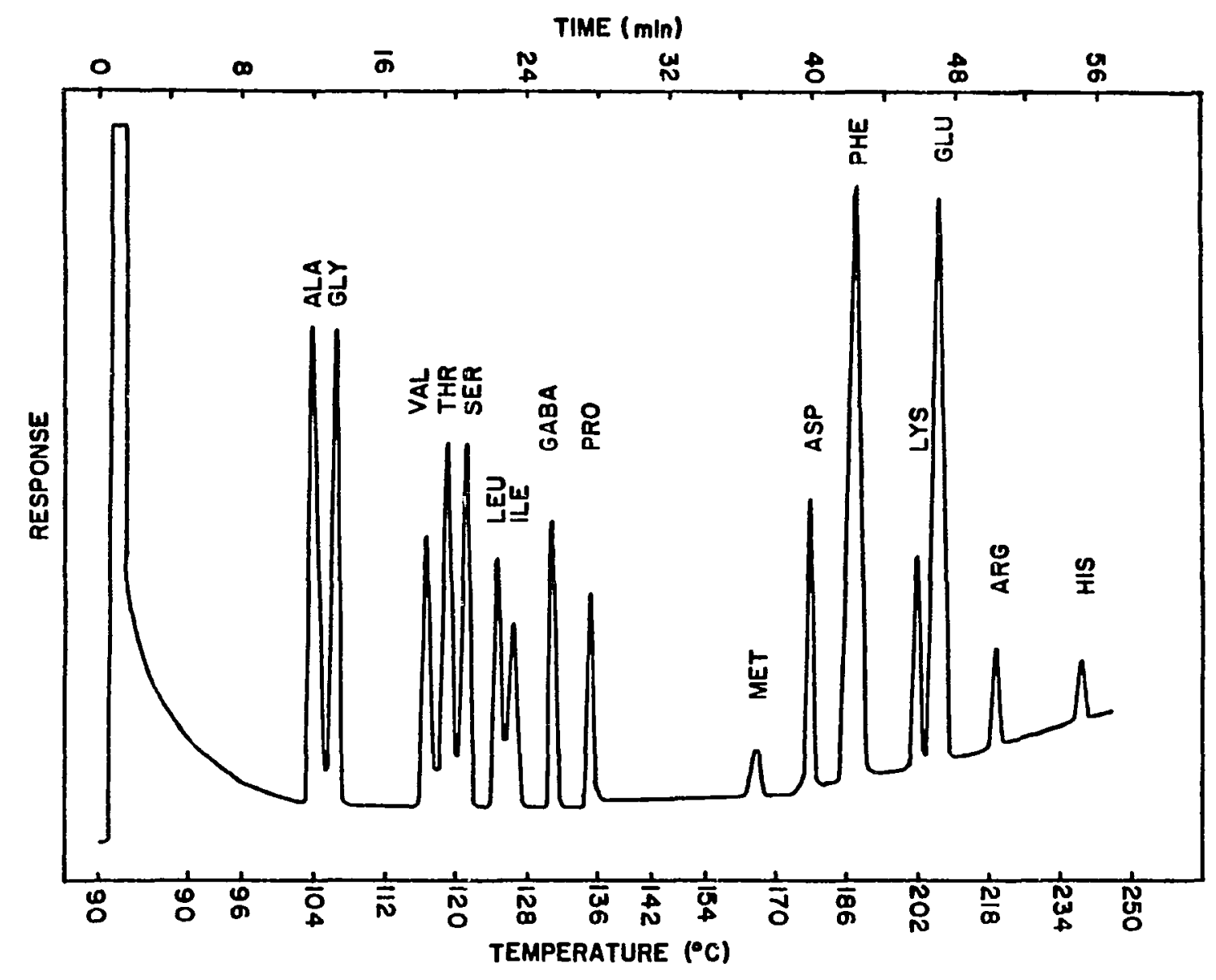

Figure 4. Typical chromatrogram: total amino acids at sampling site $\mathrm{KL}-10$, September, 1978. 
The seasonal variation in the amounts of the five most abundant amino actds at six selected sampling sites is shown in Figure 5. In general, the five most abundant amino aclds were Gly > Asp > Ala > Ser $\cong \mathrm{Glu}$. This order showed no significant variation through the river system through the two years. This relative order has been found in other river systems by other workers (Peake et al., 1972; Beck et al., 1974). The two-year averages for total amino acids at each sampling site are shown in Figure 6. The input from the marsh is clearly seen, as are the diluting effects of the many riverbed springs between WR-50 and WR-56 and of Spring Creek. At WR-50, the value shown is the average for only those months that water was flowing out of the marsh. The range at WR-50 was from 1.5 to $15.9 \mu \mathrm{M}$.

While charge considerations may cause concern for the kind of bonding occuring between the amino acids found in this research and humus, the presence of the acidic amino acids is not unexpected. Stevenson (1982) reports that the distribution of amino acids found in solls closely resembles that found for the bacterial cells in solls, Gly, Ala, Asp, and Glu belng predomlnant. Carter and Mitterer (1978) report a relative abundance for decomposing aquatic plant debris of Gly $>$ Asp $>$ Glu $>$ Ala $>$ Ser. Thus the relative distribution of amino acids assoclated with Williamson River humus closely resembles that found in two 1mportant possible sources of aquatic humus.

The two-year averages for humfc carbon are also shown in Figure 6 and are seen to closely follow the average total amino actd concentrations. $\mathrm{KL}-10$ shows anomalous behavior that is most probably due to the high concentration of algae present In Klamath Lake during the 


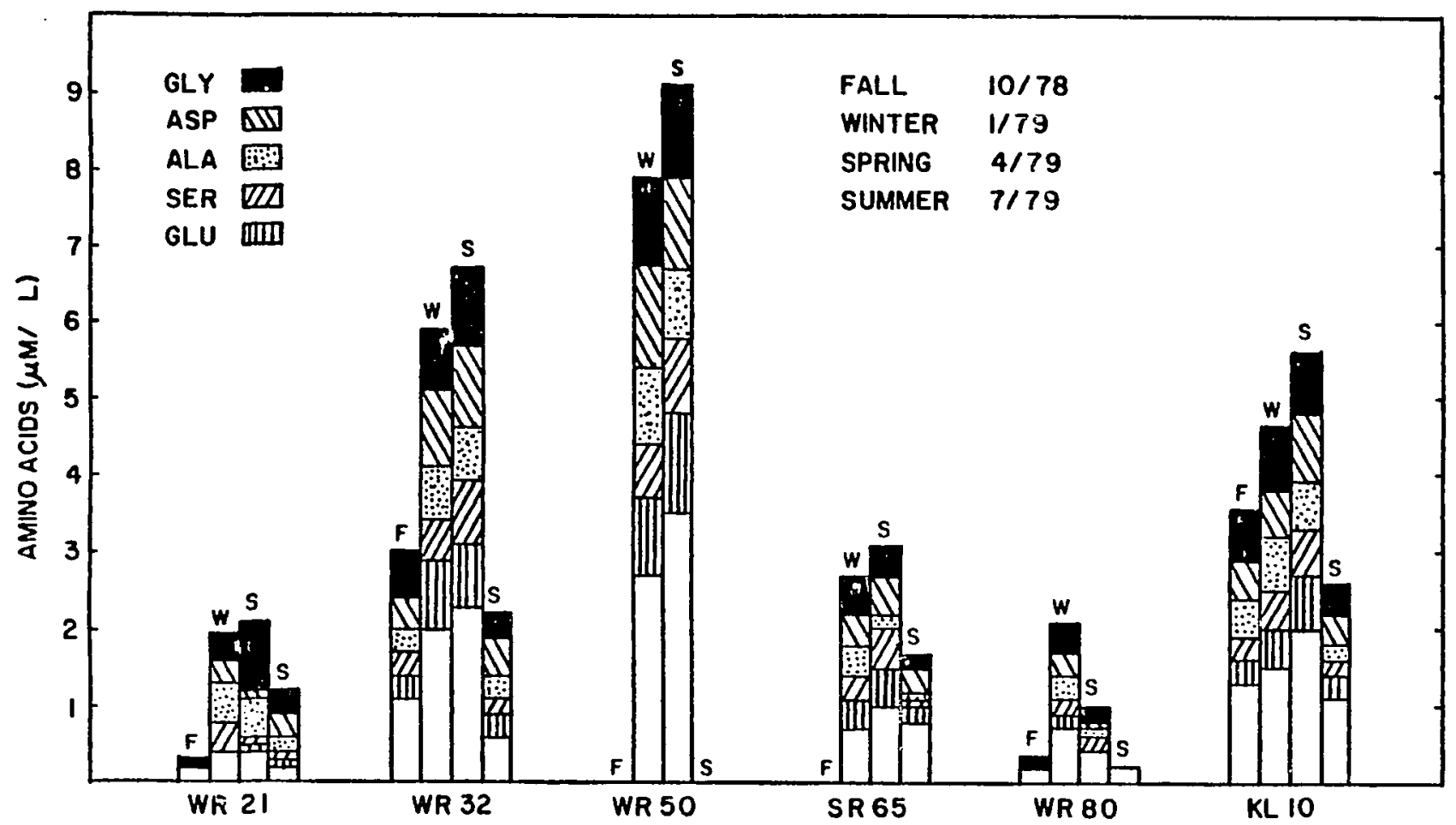

Figure 5. Seasonal amino acid distribution at selected sampling sites. 


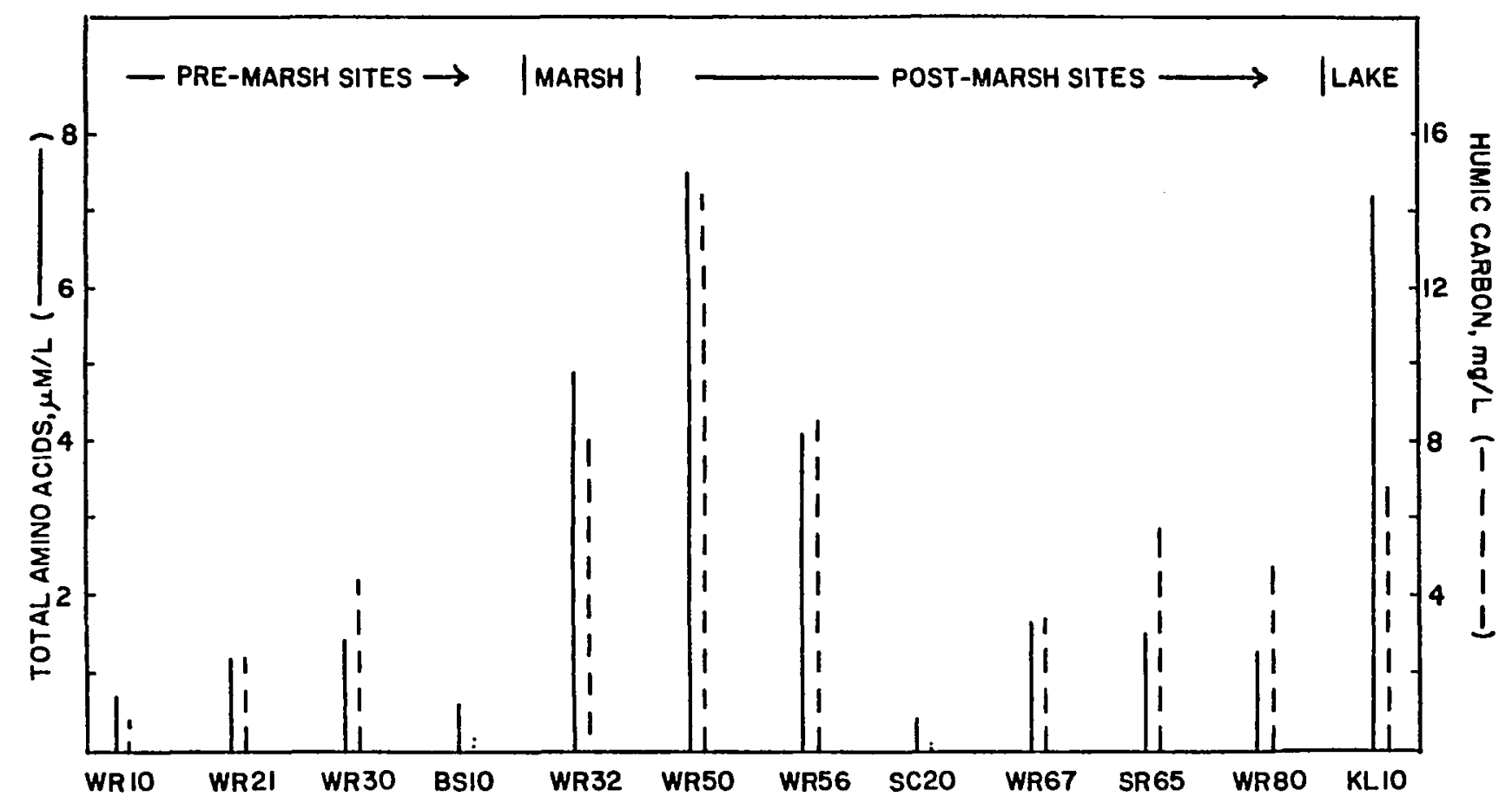

Figure 6. Two-year averages for total amino acids and humic carbon. 
summer, fall, and early winter months $(>30,000$ cells/mL of Aphanizomenon flos-aquae). When total amino acid concentrations are plotted against humic carbon, significant $r^{2}$ corrections are found. For example, Figure 7 shows such a plot for the December, 1978 fleld trip. Disregarding the anomalous $\mathrm{KL}-10$ point, the least-squares ine gave an $\mathbf{r}^{2}$ of 0.976 . This evidence suggested that most of the amino acids were assoclated with humic substances.

Generally, total amino acid concentrations were several times higher in the winter and spring months than in the summer and fall months. This seasonal pattern was also observed for humic carbon and discharge. The positive correlation among these parameters is exemplifled in Figure 8, which shows the data from the Sprague River sampling site $(S R-65)$. On the basis of these results, it appears likely that the principal source of humic carbon and amino acids is surface runoff, which flushes these components from water-saturated solls during periods of high discharge. Simflar varlations of total organic carbon with discharge have been previously noted (Beck et al., 1974; Dahm, 1980).

In view of the blological lability of free amino acids, proteins, etc., It seems likely that those amino aclds which are mobilized from solls are already assoclated with humfc substances. Thus the overall seasonal varlability of amino acld concentrations in this river system Is probably best explained by a predominant discharge-related pattern on which relatively minor biological perturbations are superimposed.

To test the hypothesis that the amino acids were assoclated with humic substances, a fractionation scheme centering on the use of the 


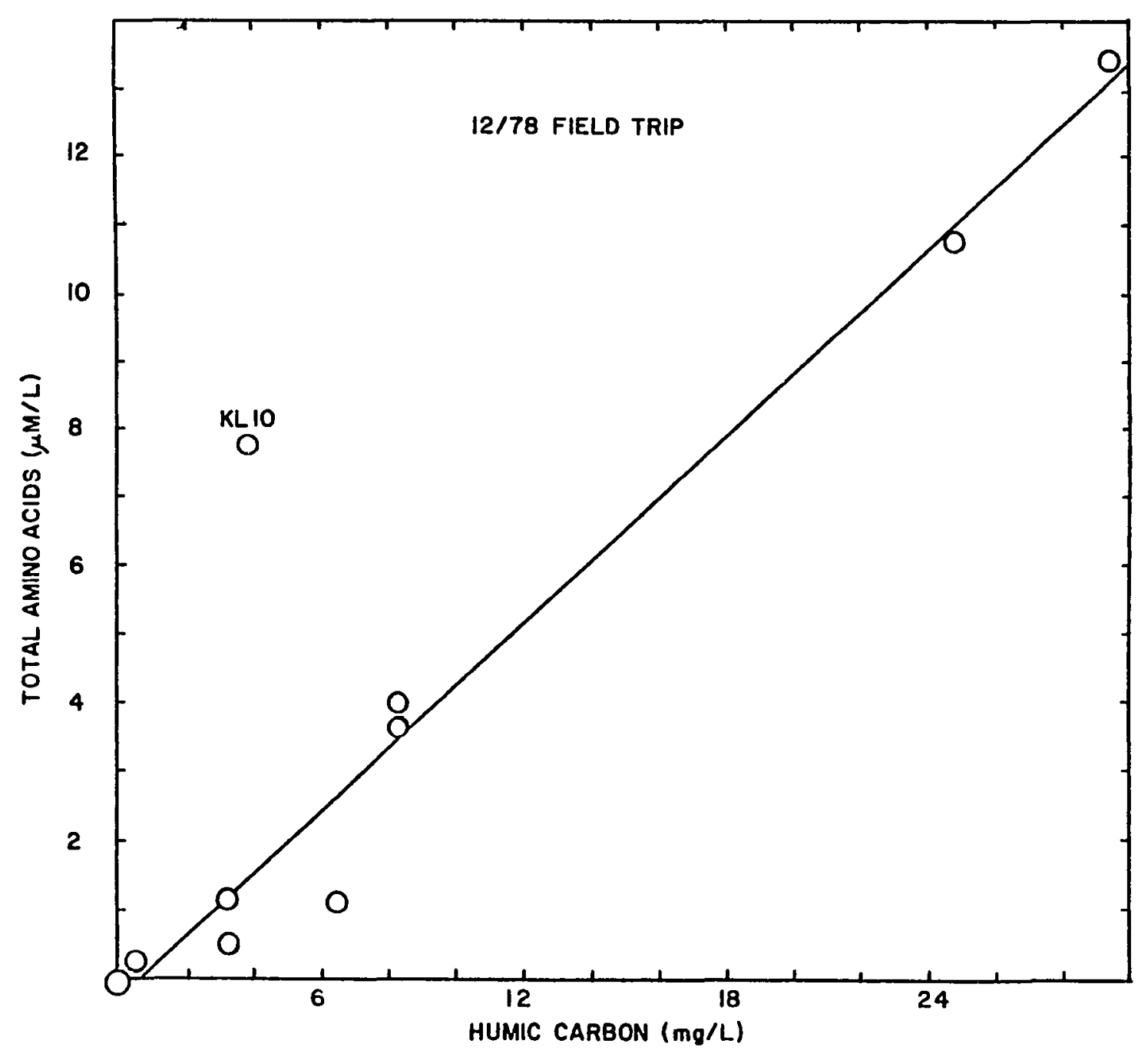

Figure 7. Total amino acids versus humic carbon for the December 1978 field trip. 


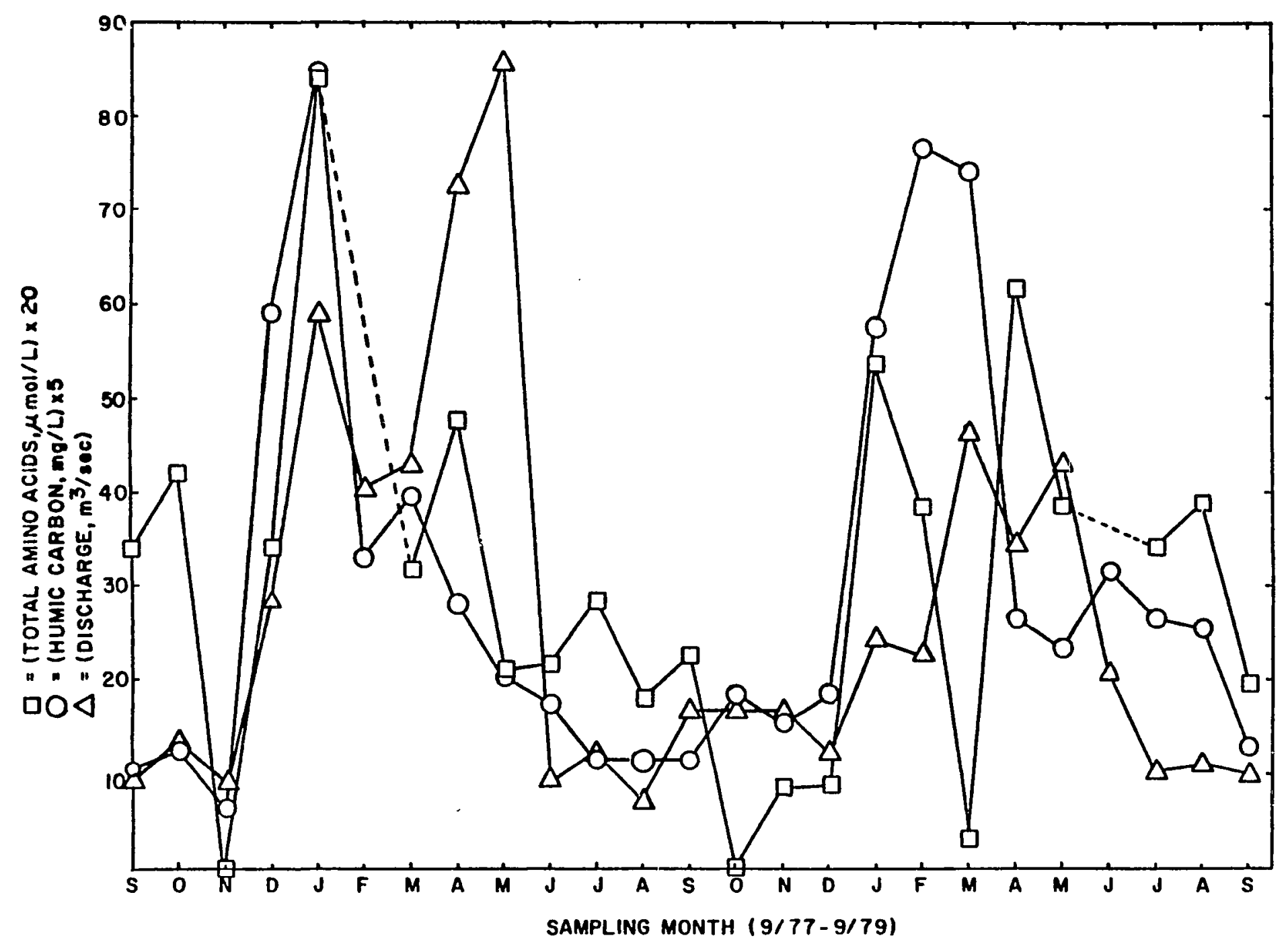

Figure 8. Discharge, humic carbon, and total amino acids at Sprague River over two years. 
macroreticular resin XAD-7 was devised. Macroreticular resins have been used to 1solate humic substances from seawater (Mantoura and R1ley, 1975; Stuermer and Harvey, 1978) and freshwaters (Weber and Wilson, 1975), and their relative performances have been recently compared (Alken et al., 1979). Three sampling sites were chosen for the study: WR-21, well before the marsh where the Williamson is a clear, dilute steam; WR-32, directly in the marsh; and WR-50, Immediately after the marsh. The results of the fractionations are shown in Figure 9. In all three cases, the humic-associated amino acids were $\geq 96 \%$ of the total dissolved amino acids. The amounts of free amino acids were below detection limit, implying that the remaining dissolved amino acids were either proteinaceous or possibly humic-assoctated amino acids that had bled through the $\mathrm{XAD}-7$ column. The high percentage of particulate amino acids at WR-21 can be accounted for by the comparatively high concentration of diatoms at this site. Cell counts average about 8,000 cells/mL (mostly Navicula ssp.), whlle WR-32 and WR-50 average about $1,700 \mathrm{cells} / \mathrm{mL}$ (mostly Fragllarla ssp.). At all three sampling sites, humic-assoclated amino acid carbon accounted for about $1 \%$ humlc carbon.

The Application of the Two-Component Scatchard Equation to Defined

\section{Ligand Mixtures.}

Assuming that the metal binding properties of aquatic humic substances could be approximated by a continum of binding sites, the two-component Scatchard equation (Eq . 18) was used to analyze a hypothetical ligand mixture in which the ligand concentrations, $c_{i}$, were normally distributed. Th1s was accomplished by solving Eq. 23 for $\bar{v}$ over 


\begin{tabular}{l} 
FRACTION \\
\hline UNFILTERED \\
PARTICULATE" \\
(\% of Unfilter 8 ) \\
FILTERED \\
HUMIC-ASSOCIATED
\end{tabular}

(\% of filtered)

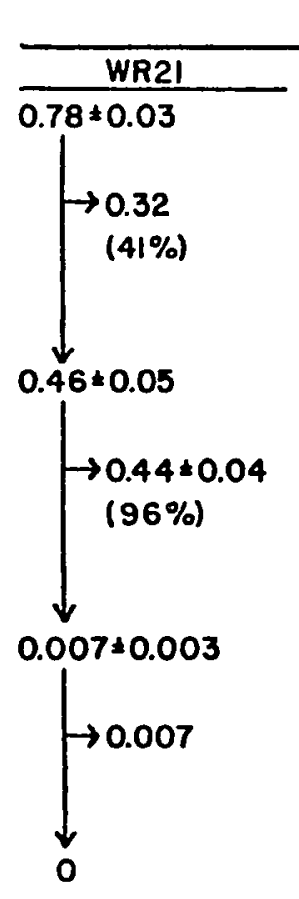

SAMPLING SITES

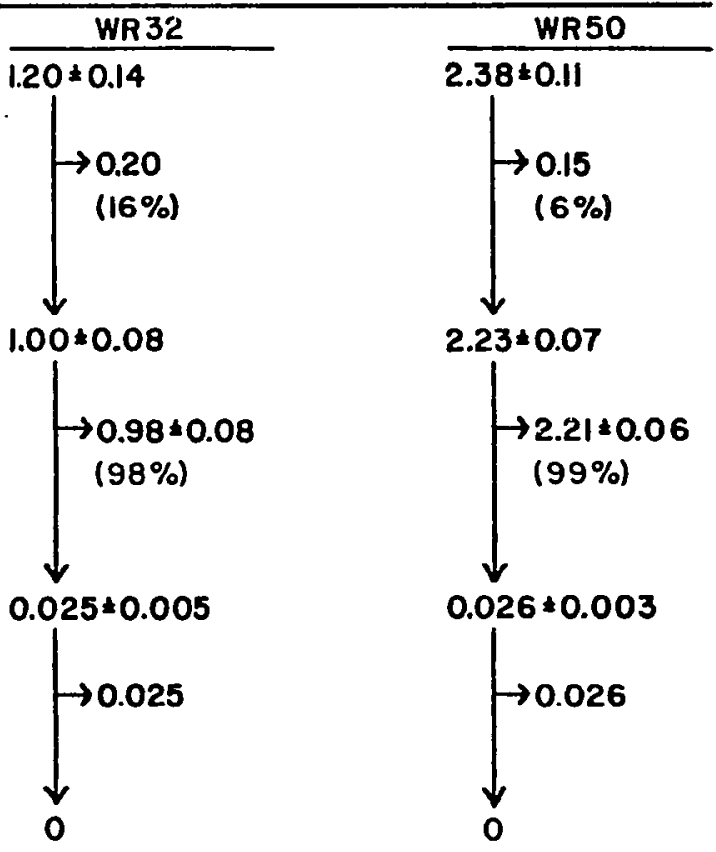

"found by difference 
the range $-11.0 \leq \log [M] \leq-3.0$ in increments of $0.1 \log$ units with a constant $C_{L}=2.0 \times 10^{-4} \mathrm{M}$ and with $\mu=2.00$ and $\sigma=3.00 . \overrightarrow{\mathrm{K}}^{\prime}$ was then calculated for each value of $[M]$ using Eq. 15. The corresponding $C_{M}$ at each value of $[M]$ is given by

$$
C_{M}=[M]+\bar{v} C_{L}
$$

The resultant $[M]$ and $C_{M}$ data were treated as if from a metal-intoligand titration and subjected to a two-component scatchard analysis. The point of the exercise was to examine the sensitivity of the Scatchard analysis to the range of $C_{L}, C_{M}$, and [M] values used to obtain the four curve-fitting parameters of the Scatchard equation: $k_{1}, c_{1} / c_{2}$, $\mathrm{K}_{2}, \mathrm{C}_{2} / \mathrm{C}_{\mathrm{L}}$

To simulate experimental limits of detection of [M], three plots of $\bar{v} /[\mathrm{M}]$ versus $\bar{v}$ were constructed (Eq. 17) assuming that the analytical detection limits for [M] were $1.26 \times 10^{-8} \mathrm{M}$ (Fit 1 ), $1.26 \times 10^{-7} \mathrm{M}$ (Fit 2), and $1.26 \times 10^{-6} \mathrm{M}$ (Fit 3 ). Using all the data points from the assumed "detection limit" to the highest value of [M], a weighted, nonlinear regression procedure (Appendix $C$ ) was used to fit the resultant curved plots to the two-component Scatchard equation (Eq. 18), yielding the "best" values of $\mathrm{K}_{1}, \mathrm{C}_{1} / \mathrm{C}_{\mathrm{L}}, \mathrm{K}_{2}$, and $\mathrm{C}_{2} / \mathrm{C}_{\mathrm{L}}$. The calculated results are tabulated in Table VI and the calculated curves are superimposed on the data in Figure 10.

From the results in Table VI, it is apparent that the values of $K_{1}$ and $C_{1} / C_{L}$ are particularly sensitive to the "detection limit," a four-fold change in $C_{M}$ leading to a 20-fold change in $K_{1} \cdot K_{2}$ and $C_{2} / C_{L}$ are relatively less sensitive to changes in $C_{M}$ because the region 


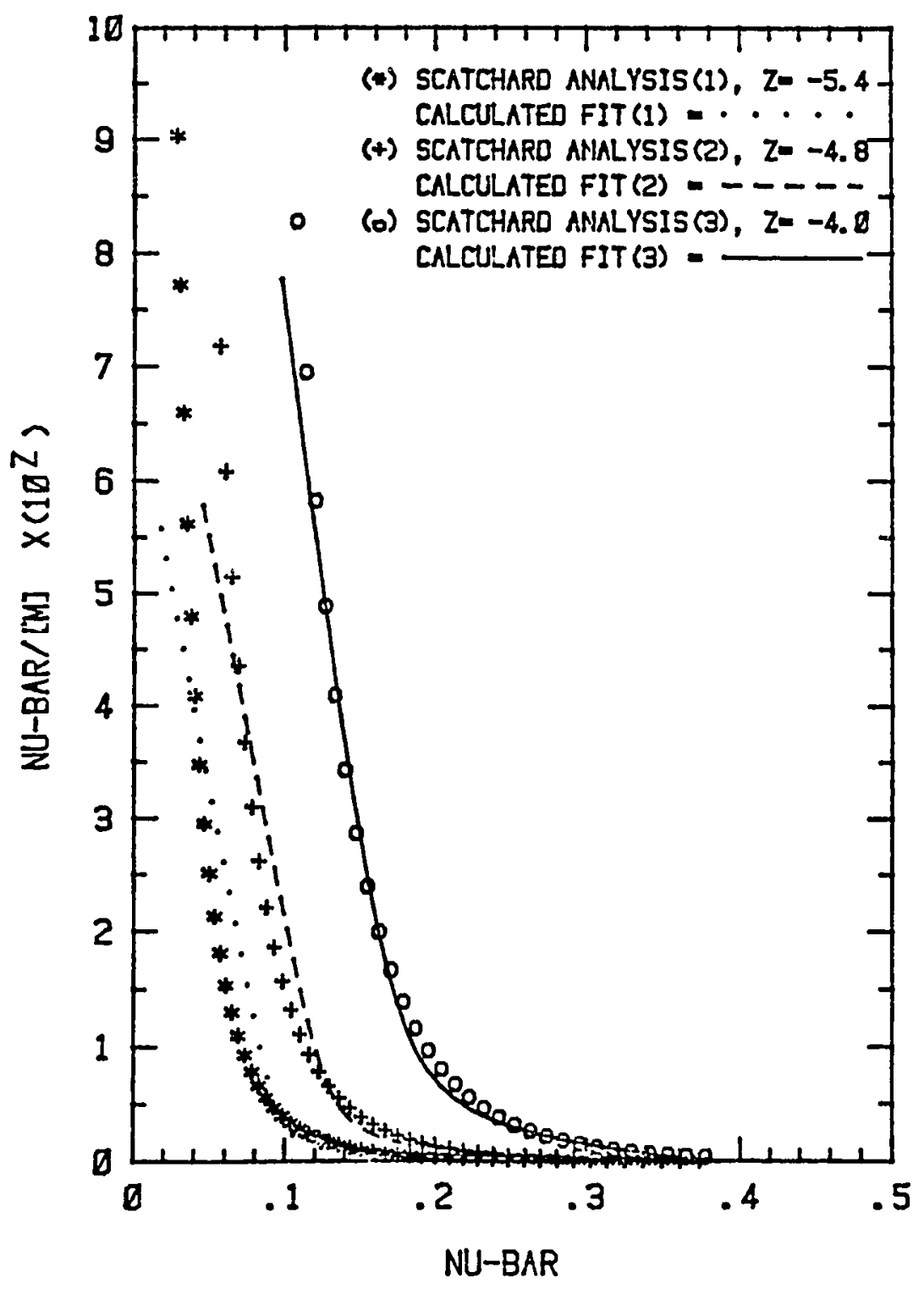

F1gure 10. Synthetically-generated and calculated fits for the Gaussian ligand set using the two-component Scatchard equation. Loyest $C_{M}$ for Fit $1=5.72 \mu \mathrm{M}$, Fit $2=11.5 \mu \mathrm{M}$, Fit $3=22.1 \mu \mathrm{M}$. 
TABLE VI

SENSITIVITY OF SCATCHARD EQUATION PARAMETERS TO

TITRATION RANGE FOR THE GAUSSIAN LIGAND SET

\begin{tabular}{lcccccc} 
Fit & Lowest $[M]$ & Lowest $C_{M}(\mu M)$ & Log $K_{1}$ & $C_{1} / C_{L}$ & $\log K_{2}$ & $C_{2} / C_{L}$ \\
\hline 1 & $1.26 \times 10^{-8} M$ & 5.72 & 7.26 & 0.094 & 4.52 & 0.243 \\
2 & $1.26 \times 10^{-7} \mathrm{M}$ & 11.5 & 6.65 & 0.126 & 4.21 & 0.234 \\
3 & $1.26 \times 10^{-6} \mathrm{M}$ & 22.1 & 6.03 & 0.166 & 3.89 & 0.220 \\
\hline
\end{tabular}

of the data set that mainly determine their value (high $\bar{v}$ ) is unchanged in the three test cases. It is also clearly the case that $K_{1}, C_{1} / C_{L}$, $\mathrm{K}_{2}$, and $\mathrm{C}_{2} / \mathrm{C}_{\mathrm{L}}$ have no chemlcal signiflcance because, rather than consisting of two ligands or even two classes of ligands, the data were generated from a continuous Gaussian distribution of "ligands" with an average $\log \overline{\mathrm{K}}^{\prime}=2.00$.

When the two-component Scatchard equation is applied to laboratory metal-humus titrations, the parameters found at the levels of $C_{M}$ measurable (typically $\geq 10^{-6} \mathrm{M}$ ) are assumed to hold at levels of $C_{M}$ found in the natural aquatic environment $\left(\leq 10^{-7} \mathrm{M}\right)$, the assumption being that goodness of fit at laboratory levels of $C_{M}$ will extend to levels of $C_{M}$ that cannot be experimentally verifiable (Bufflé et al., 1977; Bresnahan et al., 1978; Sposito et al., 1979). This can be directly tested for the computer-simulated titration. In Figure $11,10 g$ $\overline{\mathrm{K}}^{\prime}$ versus $\log \left(\mathrm{C}_{\mathrm{L}} / \mathrm{C}_{\mathrm{M}}\right)$ for the simulated data is plotted as a solid Iine. Th1s line is still rising at $\log \left(C_{L} / C_{M}\right)$ values greater than two. 


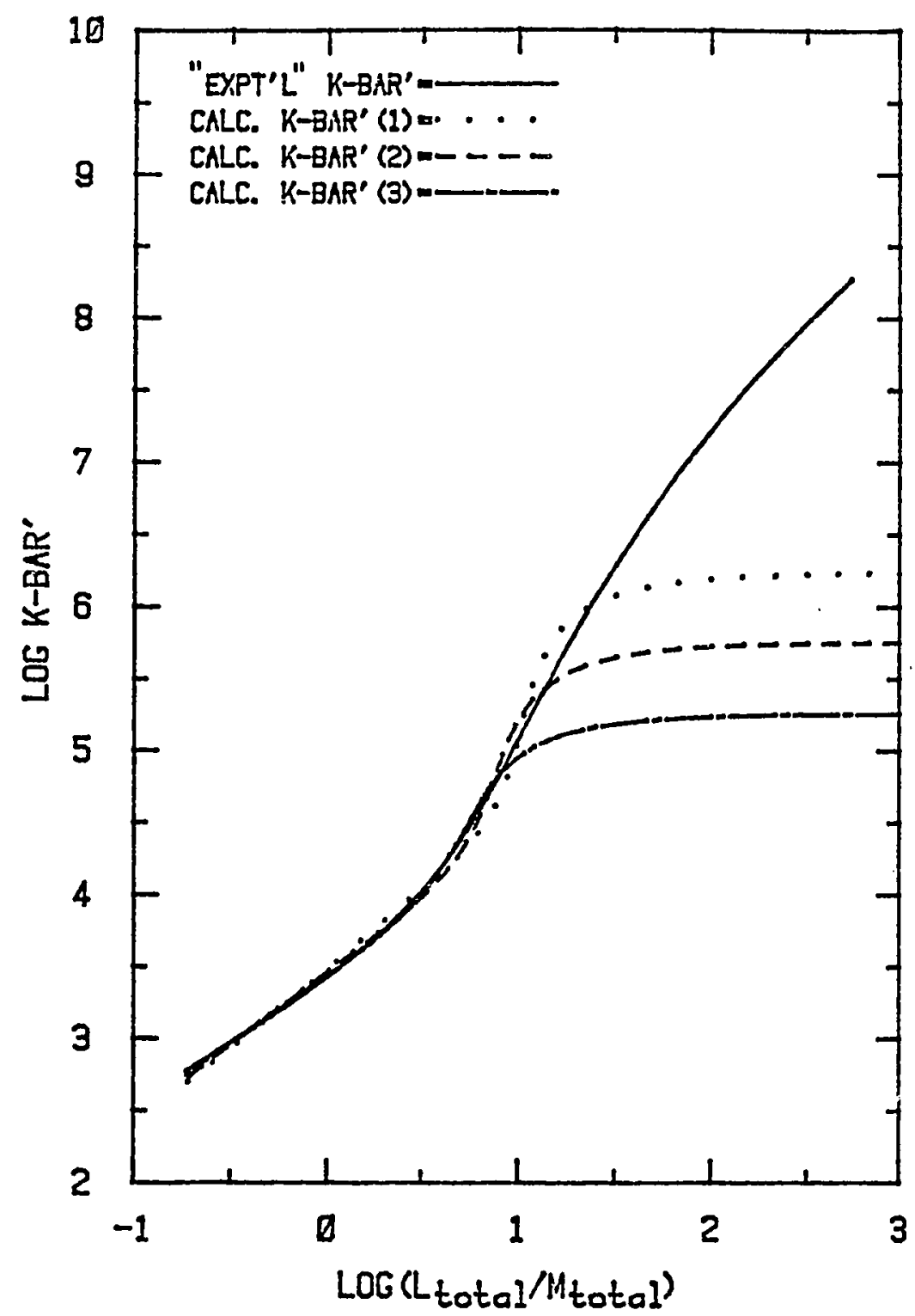

Figure 11. Synthetically-generated $\log \overline{\mathrm{K}}^{\prime}$ values for the Gaussian ligand set and $\log \overline{\mathrm{K}}^{\prime}$ values calculated from the twocomponent Scatchard equation. Lowest $C_{M}$ for Fit $1=$ $5.72 \mu \mathrm{M}$, Fit $2=11.5 \mu \mathrm{M}$, Fit $3=22.1 \mu \mathrm{M}$. 
(In natural waters containing $10 \mathrm{mg} C / L$ of aquatic humus and $C_{M}=$ $10^{-8} \mathrm{M}, \log \left(\mathrm{C}_{\mathrm{L}} / \mathrm{C}_{\mathrm{M}}\right)$ is approximately three. $)$ In contrast, all three Scatchard-fitting curves level off at $\log \overline{\mathrm{K}}^{\prime}$ values that are several orders of magnitude too low. As a result, the concentration of uncomplexed metal, $[M]$, at a $\log \left(C_{L} / C_{M}\right)$ of three $\left(2.5 \times 10^{-12} \mathrm{M}\right)$ is not accurately predicted by the scatchard fits. The best predicted [M] value $\left(1 \times 10^{-9} \mathrm{M}\right)$, which is obtained from Fit 1 with the lowest "detection limit," is still more than two orders of magnitude too high. In that fit, a departure from the gradual increase of $\log \overline{\mathrm{K}}^{\prime}$ of the Gaussian data set is seen. In fact, if the "detection 11mit" is lowered even further, the Scatchard curve will rise vertically near $\log \left(C_{L} / C_{M}\right)=$ 1. It must be pointed out that the validity of this last criticism rests on the experimentally unproven assumption that the metal binding sites of aquatic humus can be approximated by a continuous function of individual binding sites whose concentrations are normally distributed with respect to some average $\log k_{1}^{\prime}$.

To address this problem, a second test was conducted employing the Fortran program MINEQL (Westall et al., 1976). A copper titration was simulated Into a twenty-three 11gand mixture $\left(C_{L}=2.0 \times 10^{-4} \mathrm{M}\right)$ at $\mathrm{pH}$ 5.0 and $I=0.1 \mathrm{M} \mathrm{NaNO}_{3}$. Total copper was varled from $10^{-8} \mathrm{M}$ to $10^{-3} \mathrm{M}$ In steps of $0.1 \mathrm{log}$ unit. The cholce of 11 gands and concentrations was designed to produce a gradual titration curve and to avoid complexes of greater than 1:1 stolchlometry. Within these constralnts, ligand concentrations were weighted normally about the average log copper binding constant (4.58). The Individual ligands, $K_{i}^{\prime}$, and $C_{1}$ values are summarised in Table VII. The actual concentration of every chemical spe- 
TABLE VII

LIGAND SET FOR THE MINEQL SIMULATED COPPER TITRATION

\begin{tabular}{lrr} 
Ligand & Log $\mathrm{K}^{\prime}$ & Conc. $(\mu \mathrm{M})$ \\
\hline & & \\
Acetate & 1.65 & 10.45 \\
Alamine & 3.58 & 11.01 \\
Arginine & 3.58 & 11.01 \\
Aspartate & 3.98 & 10.83 \\
Citrate & 6.37 & 9.05 \\
DCTA & 14.66 & 1.87 \\
EDTA & 12.38 & 5.41 \\
Ethylenediamine & 3.78 & 9.48 \\
Glutamate & 3.41 & 11.01 \\
Glycine & 3.58 & 11.01 \\
Histidine & 6.52 & 7.93 \\
Isoleucine & 3.68 & 1.0 .92 \\
Leucine & 3.68 & 10.92 \\
Norcardamine & 3.10 & 6.72 \\
NTA & 8.34 & 3.64 \\
Ornithine & -2.42 & 0.09 \\
Oxalate & 6.14 & 8.67 \\
Phenylalanine & 3.68 & 10.92 \\
Phthalate & 2.99 & 11.01 \\
Salicylate & 2.26 & 10.45 \\
Sulfosalicylate & 3.44 & 11.01 \\
Tartrate & 3.37 & 10.55 \\
Valine & 3.48 & 11.01 \\
Tal & & \\
\hline & &
\end{tabular}

cles at each "titration" point is given in the program output, so the system is essentially defined and is easily reproduced by other researchers with access to MINEQL. The given $C_{M}$ and calculated [M] data were subjected to a two-component Scatchard analysis for three "detection limits" for $C_{M}:$ Fit $1=6.31 \mu \mathrm{M}$, Fit $2=12.6 \mu \mathrm{M}$, and Fit $3=20.0 \mu \mathrm{M}$. Agatn, the $\bar{v} /[M]$ versus $[M]$ plots were analyzed with a welghted, nonlinear regression fit to Eq. 18, ylelding the "best" values of $k_{1}, C_{1} / C_{L}$, $\mathrm{K}_{2}$, and $\mathrm{C}_{2} / \mathrm{C}_{\mathrm{L}}$. The calculated results are tabulated in Table VIII, and 
the calculated curves are superimposed on the data in Figure 12. The three data subsets above were also analyzed with a welghted, nonlinear regression fit to the Gaussian equation (Eq. 23). The "best" values of $\mu$ and $\sigma$ are also tabulated in Table VIII.

TABLE VIII

GAUSSIAN AND SCATCHARD FITS FOR THE COPPERTWENTY-THREE LIGAND MINEQL SIMULATED TITRATION

\begin{tabular}{|c|c|c|c|c|c|c|c|}
\hline \multirow[b]{2}{*}{ Fit } & \multirow[b]{2}{*}{ Lowest $C_{M}(\mu M)$} & \multicolumn{2}{|c|}{ Gaussian Fit } & \multicolumn{4}{|c|}{ Scatchard Fit } \\
\hline & & $\mu$ & $\sigma$ & $\log K_{1}$ & $\mathrm{c}_{1} / \mathrm{c}_{\mathrm{L}}$ & $\log \mathrm{K}_{2}$ & $\mathrm{C}_{2} / \mathrm{C}_{\mathrm{L}}$ \\
\hline 1 & 6.31 & 3.28 & 3.41 & 8.27 & 0.095 & 3.97 & 0.657 \\
\hline 2 & 12.6 & 3.64 & 1.77 & 6.88 & 0.130 & 3.82 & 0.674 \\
\hline 3 & 20.0 & 3.71 & 1.42 & 6.86 & 0.138 & 3.79 & 0.675 \\
\hline
\end{tabular}

The predictions of the Scatchard and Gaussian models for $\log \overline{\mathrm{K}}^{\prime}$ for the MINEQL data set were compared using that portion of the data set for which the lowest $C_{M}=6.31 \mu M$. The "best" values of the respective curve-fitting parameters are given in Table VIII, and the calculated log $\overline{\mathrm{K}}^{\prime}$ versus $\log \left(C_{L} / C_{M}\right)$ for each model is shown in Figure 13 . Nelther model is very effective at describing the simulated curve at both the low $C_{L} / C_{M}$ values found in most laboratory studies and the high $C_{L} / C_{M}$ values that typify natural waters. The Gaussian model is more successful in the extrapolation to high $C_{L} / C_{M}$ values, even though it contains only half as many curve-fitting parameters as the two-component Scatchard model. This is interesting in view of the fact that the MINEQL ligand set is not continuous and non-Gaussian. The flat region 


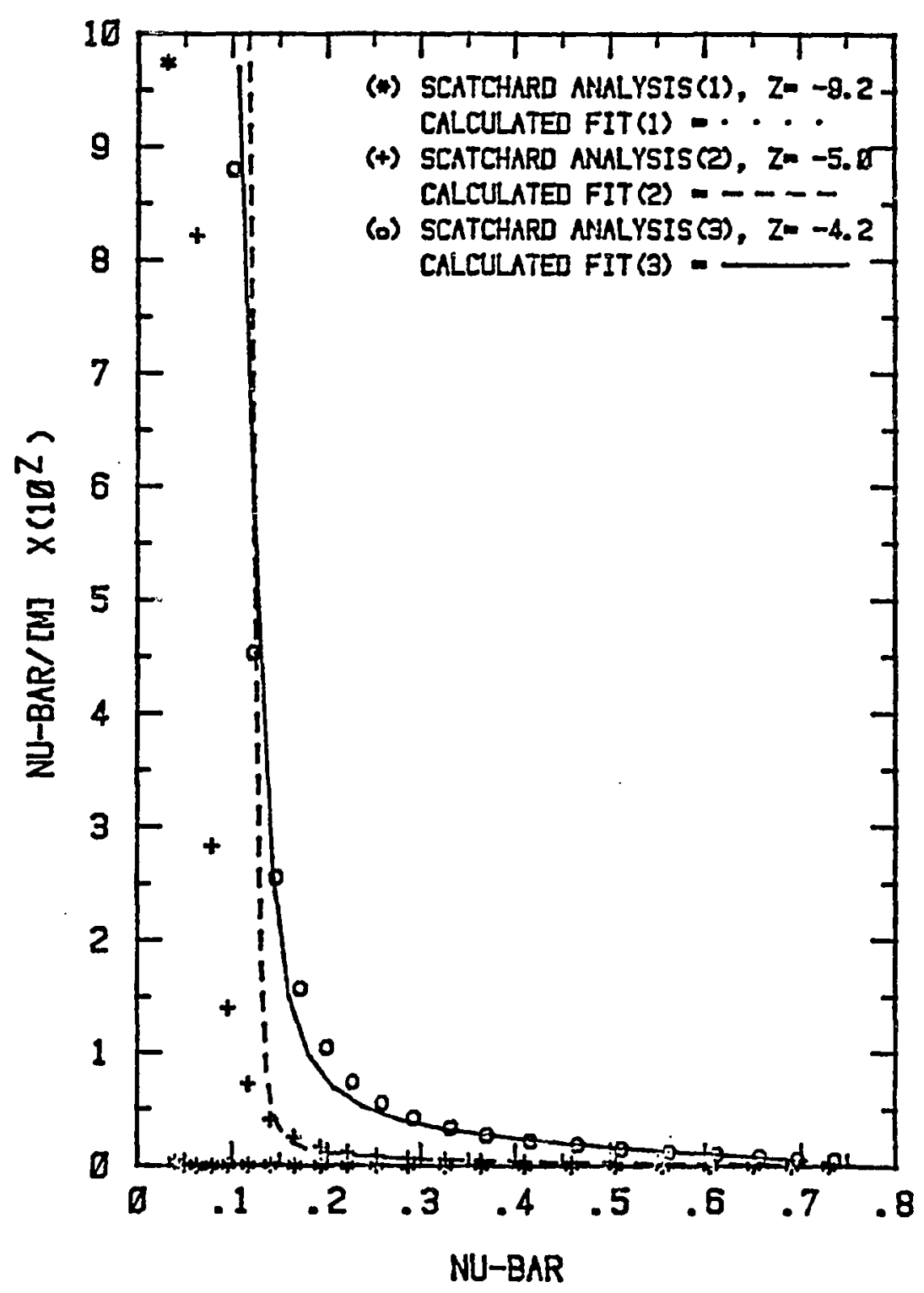

Figure 12. Synthetically-generated $\bar{v}$ and calculated fits for the MINEQL ligand set using the two component Scatchard equation. Lowest $C_{M}$ for Fit $1=6.31 \mathrm{mM}$, Fit $2=12.6 \mu \mathrm{M}$, Fit $3=20.0 \mu \mathrm{M}$. 


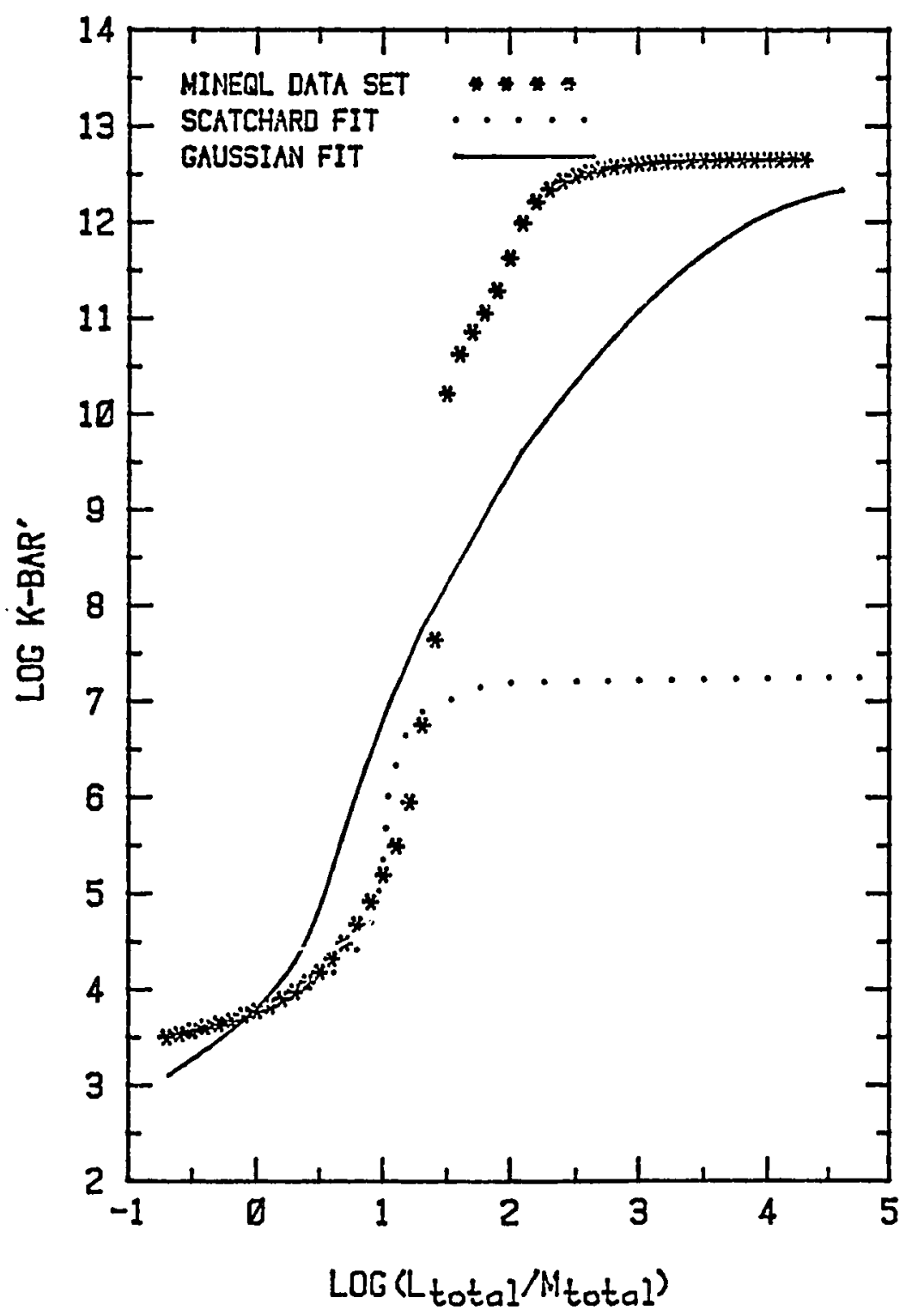

Figure 13. Simulated $\log \overline{\mathrm{K}}^{\prime}$ values and calculated fits for the MINEQL ligand set using the Scatchard and Gaussian models. Lowest $C_{M}$ in data subset used to find fitting parameters $=6.31 \mu \mathrm{M}$. 
of the $\log \overline{\mathrm{K}}^{\prime}$ above a $\log \left(\mathrm{C}_{\mathrm{L}} / \mathrm{C}_{\mathrm{M}}\right)$ of three is due to the titration of the strongest ligand in the data set.

Humlc substances are almost certainly intermediate in complexity between the discrete, twenty-three 1igand MINEQL simulation and the continuous distribution of ligands exemplified by the Gaussian simulation. Intuitively, a distribution model is probably a better representation of humic substances, even if the actual binding site distribution in humus is non-Gaussian.

The last area to be examined in the application of the Scatchard model to metal binding with aquatic humus is the assertion that the successful application of the two-component Scatchard model results in two average constants for two types of binding sites (cf Sposito, 1981). The presence of two types of acidic functional groups in humus, carboxylic and phenolic/salicylic, has been well-established (Stevenson and Butler, 1969; Schnitzer and Khan, 1972). This knowledge has been used to support the idea that average metal binding constants for these two groups exist and can be successfully found via application of the twocomponent Scatchard equation to metal-humus titration data. The theoretical discussion in Chapter III showed that, while classes of binding sites may well exist in humic substances, any average binding "constant" will vary during the course of a metal-humus titration. The parameters derived from any truncated discrete model will be constant only if every binding site within a class has the same metal binding constant.

The postulated inadequacy of discrete models was tested by representing "classes" of ligands or binding sites as normal distribuitions. A system containing two discrete ligands ( $\log \mathrm{K}_{1}=6.16, \mathrm{C}_{1} / \mathrm{C}_{\mathrm{L}}=0.21$, 
$\left.\log \mathrm{K}_{2}=4.22, \mathrm{C}_{2} / \mathrm{C}_{\mathrm{L}}=0.79\right)$ and a system containing two normally distributed classes of ligands $\left(\theta=0.21, \mu_{1}=6.16, \mu_{2}=4.22\right.$, $\sigma_{1}=\sigma_{2}=1.0$ ) are shown In Figure 14 , in which the distribution of ligands with respect to $\log K_{1}$ values is given. The values for $\log K_{1}=$ $\mu_{1}$ and $\log K_{2}=\mu_{2}$ are representative of values reported in the literature for Scatchard analyses of metal-humus complexation reactions (Mantoura and Riley, 1975; Bresnahan et al., 1978; Alberts and Giesy, 1981; McKnight et al., 1982). From Fig. 14, it is apparent that the discrete, two-ligand system becomes equivalent to the bimodal Gaussian system as $\sigma_{1}$ and $\sigma_{2}$ approach zero. Accordingly, the two-component Scatchard equation is expected to more accurately model the nature of the Gaussian system as both $\sigma_{1}$ and $\sigma_{2}$ in that system approach zero. This expectation was confirmed by generating data sets derived from bimodal Gaussian distributions with variable $\sigma$ values via Eq. 23, Eq. 24, and Eq. 17, and then fitting these data sets to the twocomponent Scatchard equation. The Gaussian parameters were as above: $\theta=0.21, \mu_{1}=6.16, \mu_{2}=4.22$, and $0.1 \leq \sigma_{1}=\sigma_{2} \leq 4.0$. The titrations were simulated by allowing $\log [\mathrm{M}]$ to vary from -11.0 to -3.0 in steps of $0.2 \mathrm{log}$ units. The Scatchard parameters were determined on each entire data set using a weighted, nonlinear regression analysis to Eq. 18 (Appendix C).

The "best" Scatchard fitting parameters for each of the simulated titrations as a function of the ligand distribution $\sigma$ value are given in Figure 15. The actual results showed minor random deviations from the smooth curves given in Fig. 15, probably due to the fairly coarse convergence criterion used to minimize computer time in the nonlinear 


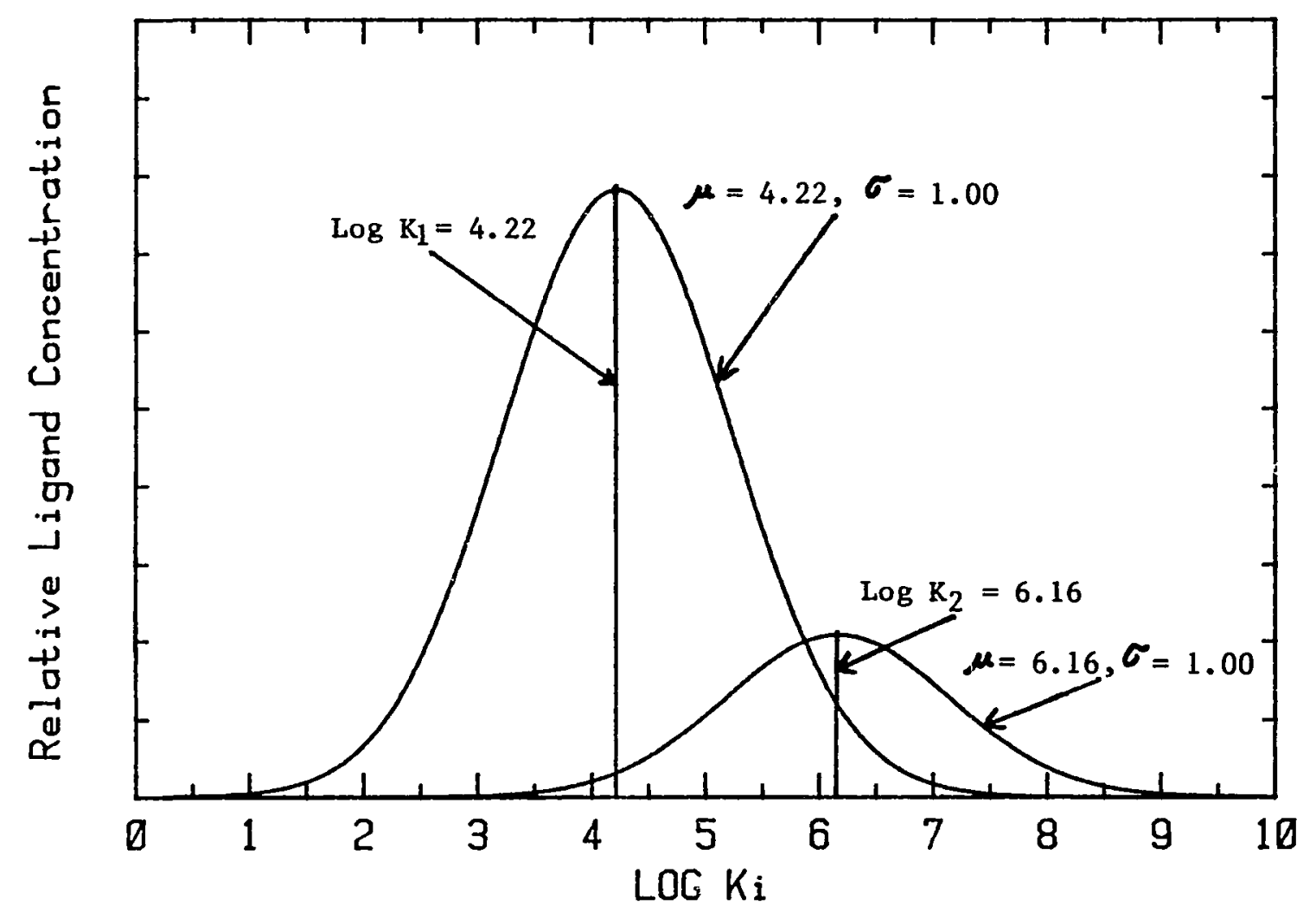

Figure 14. Comparisons of discrete and continuous ligand mixtures. 


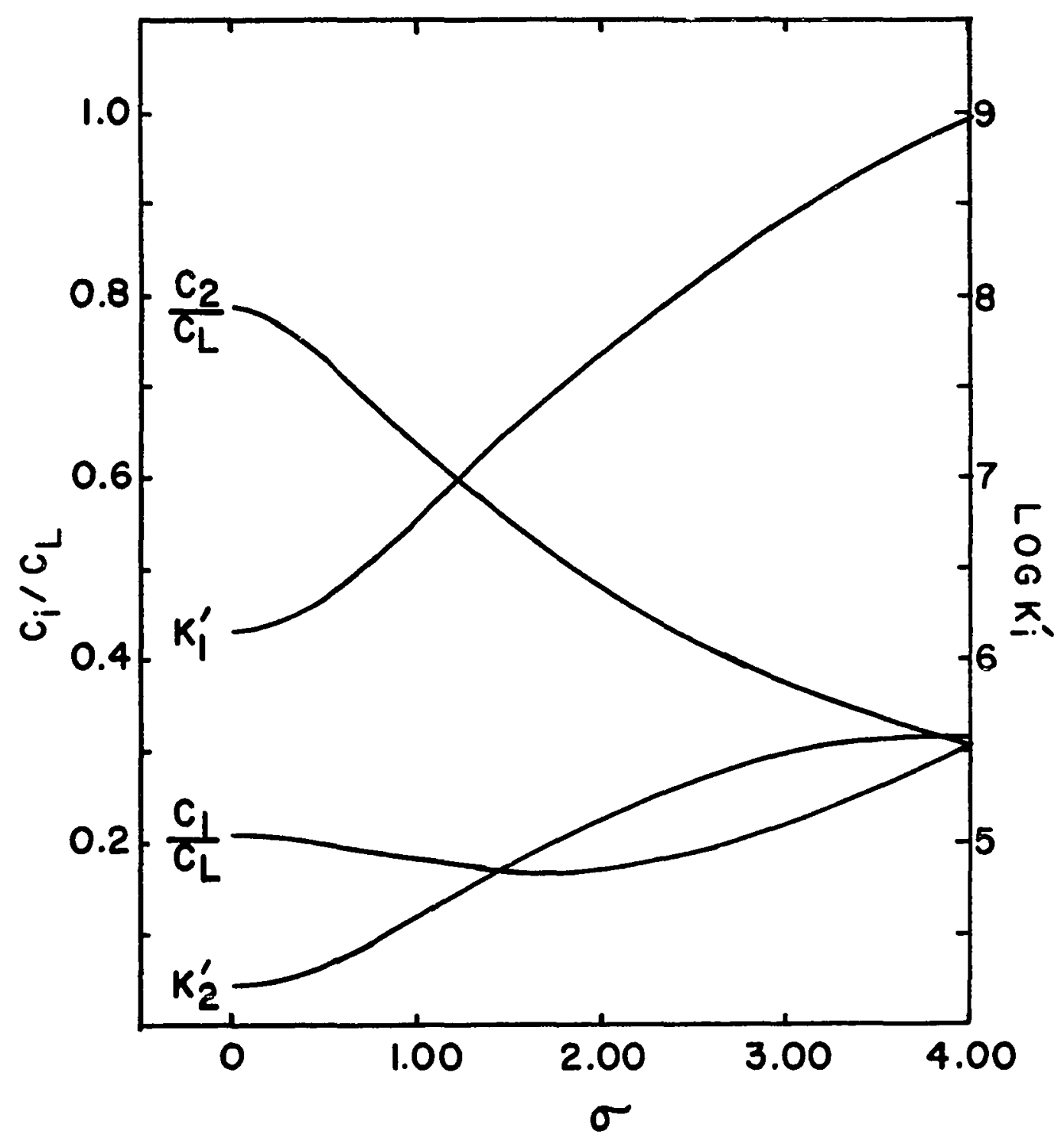

Figure 15. Variation of Scatchard parameters with the standard deviation of a continuous distribution of ligands. 
regression program. At very small $\sigma$ values, the calculated Scatchard paramters $\left(\log K_{1}, c_{1} ! \cdot L, \log K_{2}, c_{2} / C_{L}\right)$ are very close to the actual parameters used to generate the bimodal Gaussian distribution $\left(\mu_{1}, \theta\right.$, $\left.\mu_{2}, \theta-1\right)$. As $\sigma$ increases, the Scatchard parameters $\log K_{1}$ and $\mathrm{C}_{2} / \mathrm{C}_{\mathrm{L}}$ deviate dramatically from $\mu_{1}$, and $(1-\theta)$. It is clear that the two-component Scatchard model correctly predicts the average binding constants of the two distributions only when $\sigma$ approaches zero, the limiting case in which a distribution does not in fact exist. For finite values of $\sigma$, the Scatchard parameters are in error. Thus the proposition that, even if classes of ligands exist with a finite range of binding constants, the Scatchard equation yields the average constants for classes (Sposito, 1981) is false.

By definition, the sum of the relative abundances of classes of ligands equals one. Likewise, the sum of $c_{1} / C_{L}$ and $C_{2} / C_{L}$ theoretically equals one if $\mathrm{C}_{\mathrm{L}}$ is defined as the total concentration of binding sites. From Fig. 15, the sum of $C_{1} / C_{L}$ and $C_{2} / C_{L}$ is seen to gradually decrease from 1.0 to 0.6 as 7 increases from 0.1 to 4.0 . Thus, these fitting parameters cannot possibly represent actual abundances of binding sites. It was shown above that the two-component Scatchard model does not correctly predict the average binding constants for two distributions of 1igands that were used to simulate a metal-humus titration. It can also be shown that, given a system containing two classes of normally distributed ligands, the $\overline{\mathrm{K}}_{\mathrm{I}}^{\prime}$ and $\overline{\mathrm{K}}_{\mathrm{II}}^{\prime}$ calculated from the simulated titration data are not constant. A data set was generated using Eq. 24 and Eq. 23 and the parameters $=0.21, \mu_{1}=6.16, \mu_{2}=4.22, \sigma_{1}=\sigma_{2}=1.00$, $C_{L}=1 \times 10^{-4} \mathrm{M}$. The values of $\overline{\mathrm{K}}_{\mathrm{I}}^{\prime}, \overline{\mathrm{K}}_{\mathrm{II}}^{\prime}, \overline{\mathrm{K}}^{\prime}$, and $\bar{v}$ were calculated for 
the simulated titration for $10^{-11} M \leq[M] \leq 10^{-3} M$. The results, given In Figure 16, clearly show that $\overline{\mathrm{K}}_{I}^{\prime}$ and $\overline{\mathrm{K}}_{\mathrm{II}}^{\prime}$ vary continuously and cannot be considered as constants except under extreme excess ligand concentration, as described by MacCarthy and Smith (1979). The $\log \mathrm{K}_{1}$ and $\log K_{2}$ values from the Scatchard analysis of this data set are 6.77 and 4.60 and are not equivalent to $\log \overline{\mathrm{K}}_{\mathrm{I}}^{\prime}$ and $\log \overline{\mathrm{K}}_{\mathrm{II}}^{\prime}$ or to $\mu_{1}$, and $\mu_{2}$, the mean $\log \overline{\mathrm{K}}^{\prime}$ values of the two classes of ligands. (See Fig. 15.)

The Application of the Contirious Distribution Model to Proton and Copper Binding by Aquatic Humus.

To illustrate the ability of the bimodal Gaussian distribution model to describe proton binding by aquatic humus, the model was used to fit data from a titration of Williamson River humus in $0.1 \mathrm{M} \mathrm{NaClO}_{4}$ with $1.516 \mathrm{M} \mathrm{NaOH}$. In this case, the definition of $\bar{v}$, as given by Perdue et al. (1980), is

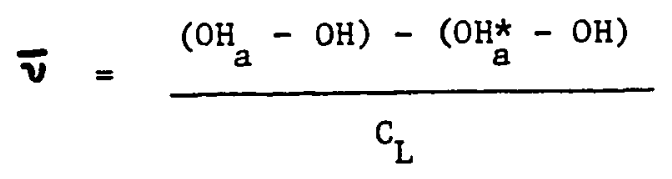

where OHa is the mols of base added, OH is the mmols of based found, (*) denotes values for a reagent blank titration, and $C_{L}$ is the total molar acidity of the humus. For the titrations done in this study, $\left(\mathrm{OHa}-\mathrm{OH}^{*}\right)$ was large and irreproducable at beyond $\mathrm{pH} 12$, presumably due to the large sodium error of the glass electrode (Skoog and West, 1963; Laitinen and Harris, 1975). For this reason, $\bar{v}$ was calculated only for titration points for which the blank was $<1 \%$ of $\left(\mathrm{OH}_{\mathrm{a}}-\mathrm{OH}\right)$. One problem in the direct titration of humic substances is the 


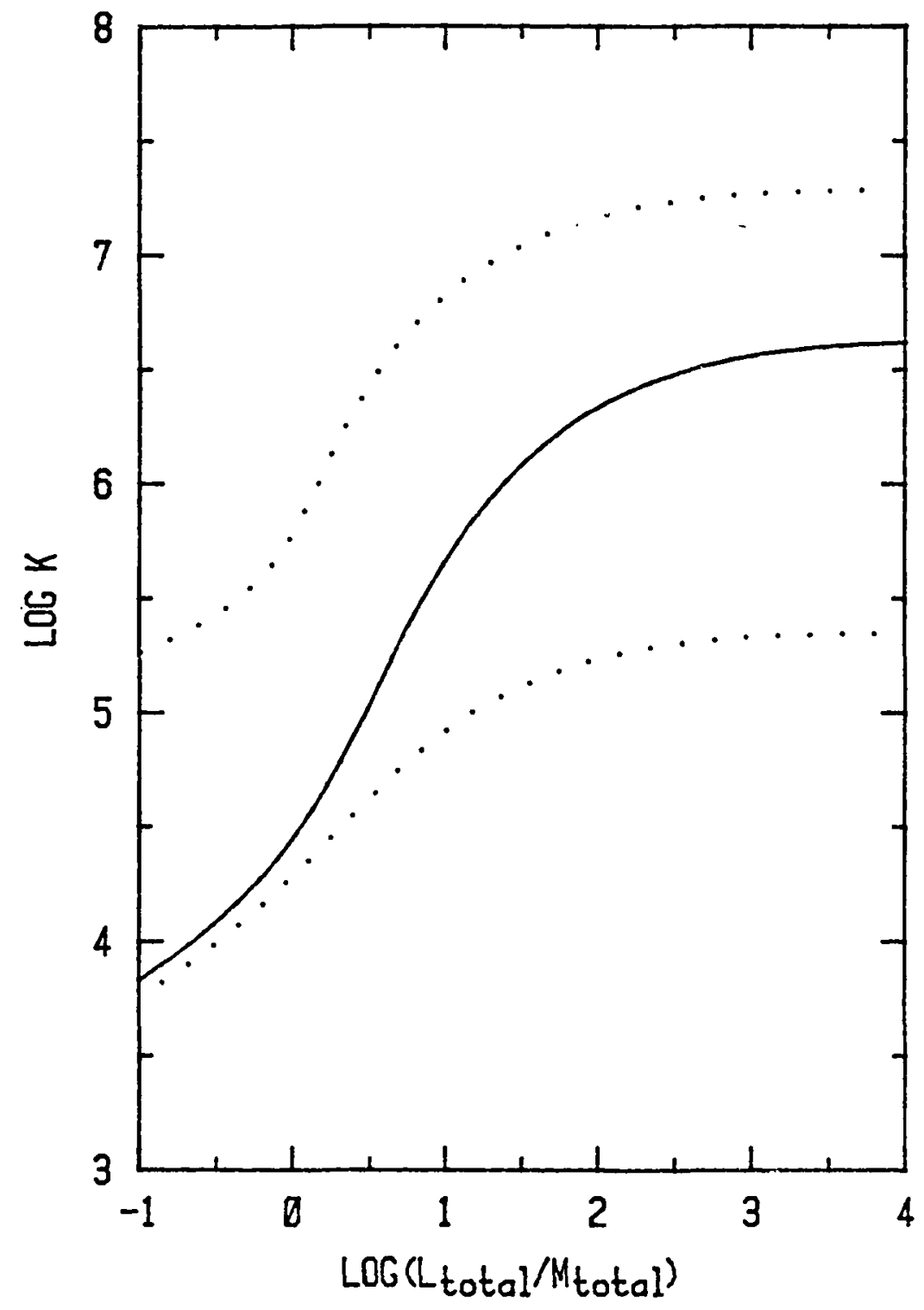

Figure 16. Computed values of $\overline{\mathrm{k}}^{\prime}(\longrightarrow)$ and $\overline{\mathrm{k}}_{\mathrm{I}}^{\prime}$ and $\overline{\mathrm{k}}_{\mathrm{II}}^{\prime}$ $(\ldots)$ for a simulated metal titration into a continuous, bimodal Gaussian distribution of ligands. 
operational nature of $\mathrm{C}_{\mathrm{L}}$ used in Eq. 26. This problem has been thoroughly discussed by Perdue et a1. (1980) and is clearly seen in Figure 17, which shows the numerator of Eq. 26 plotted against pH for a titration of the $4500 \mathrm{mg} / \mathrm{L}$ solution of Williamson River humus. In this case, $\mathrm{C}_{\mathrm{L}}$ is taken as the value of $\left(\mathrm{OH}_{a}-\mathrm{OH}\right)$ at the last titration point: 0.372 mmols OH or $9.30 \mathrm{mmols} \mathrm{OH} / \mathrm{g}$ humus. It can be clearly seen that at this point the titration curve is still rising. Thus, the $C_{L}$ found in this way is at best a lower limit, and the value for $C_{L}$ and the corresponding values for must be considered as operational only. It should be noted that the total acidity of a different sample of Williamson River humus was found to be 9.5 mols $\mathrm{H} / \mathrm{g}$ humus by Perdue (1979), using the barium hydroxide method. While this procedure has been historically accepted to yield a measure of all of the acidic hydrogens in humus (Schnitzer and Khan, 1972), it is now thought that this method also underestimates total acidity (Perdue et al., 1980). An estimate of the upper limit of $\mathrm{C}_{\mathrm{L}}$ can be obtained from examining the functional group analysis presented for Williamson River humus by Perdue (1979). Titration calorimetry, which gives a lower limit for carboxyl content (Perdue et al., 1980), yielded a value of $3.3 \mathrm{meq} / \mathrm{g}$ humus. The calcium acetate method, which gives a value for carboxyl content that is too high due to analytical problems in the procedure (Perdue et al., 1980), yielded a value of $5.1 \mathrm{meq} / \mathrm{g}$ humus. This yields a possible range for carboxyl content of $0.35-0.54$ of the total acidity. The $\overline{\boldsymbol{v}}$ values from the humus proton titration were varied to reflect a range of $C_{L}$ values so that the resulting fitting parameter, theta, fell within the above range. (Theta is the fraction of $C_{L}$ in the 


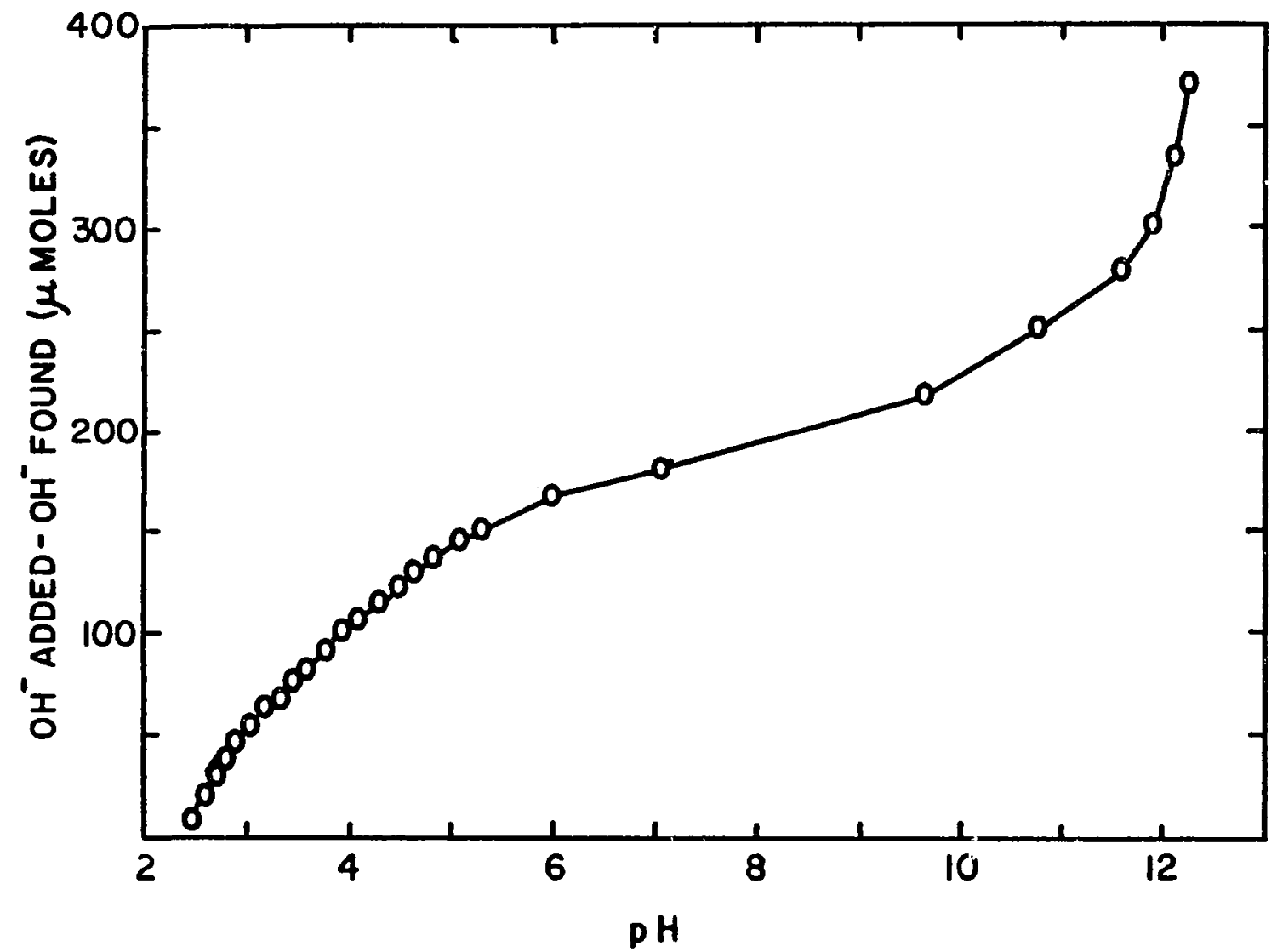

Figure 17. Base-titratable functional groups versus $\mathrm{pH}$ for a $4 \mathrm{~g} / \mathrm{L}$ solution of Williamson River humus in $0.1 \mathrm{M} \mathrm{NaClO}_{4}$. 
first, or lower $\mu$ distribution.) The results are given in Table IX. It can be seen that the above range of carboxyl content is approximated by a total acidity range of about 9.0 to $15.0 \mathrm{mmols} \mathrm{OH} / \mathrm{g}$ humus.

TABLE IX

VARIATION IN BIMODAL GAUSSIAN FITTING PARAMETERS WITH CHANGE IN $C_{L}$

\begin{tabular}{cccccc} 
(mmols $\begin{array}{ccccc}\mathrm{C}_{\mathrm{L}} \\
\mathrm{H} / \mathrm{g} \text { humus) }\end{array}$ & $\theta$ & $\mu_{1}$ & $\sigma_{1}$ & $\mu_{2}$ & $\sigma_{2}$ \\
\hline 9.0 & 0.35 & 3.56 & 0.008 & 10.48 & 2.89 \\
9.3 & 0.31 & 3.42 & 0.021 & 9.89 & 3.88 \\
10.0 & 0.34 & 3.16 & 0.52 & 9.72 & 4.21 \\
11.0 & 0.39 & 2.84 & 0.80 & 9.66 & 4.35 \\
12.0 & 0.44 & 2.54 & 1.01 & 9.64 & 4.40 \\
13.0 & 0.48 & 2.27 & 1.16 & 9.63 & 4.44 \\
14.0 & 0.53 & 1.99 & 1.30 & 9.61 & 4.46 \\
15.0 & 0.56 & 1.80 & 1.38 & 9.59 & 4.49 \\
\hline
\end{tabular}

For the purpose of this research, total acidity will be taken as the midpoint of this range of values, 12.0. The $\bar{v}, \mathrm{pH}$ experimental data (assuming $C_{L}=12.0$ mmols $\mathrm{H} / \mathrm{g}$ humus) and the calculated fit (using the "best" parameter estimates for $C_{L}=12.0$ given in Table $X$ ) are shown in Figure 18. The experimental data are fit to within a relative error of $3 \%$ to $\mathrm{pH} 7$. From this point to $\mathrm{pH} \mathrm{12,} \mathrm{the} \mathrm{data} \mathrm{ara} \mathrm{fit} \mathrm{less} \mathrm{well,}$ most probably due to the lack of data points through the inflection region between $\mathrm{pH} 7$ and 10 . Considering that the Gaussian function may not be the most appropriate description of proton binding sites in aquatic humus, the fit was considered to be satisfactory. Examination of the Gaussian parameters themselves further substan- 


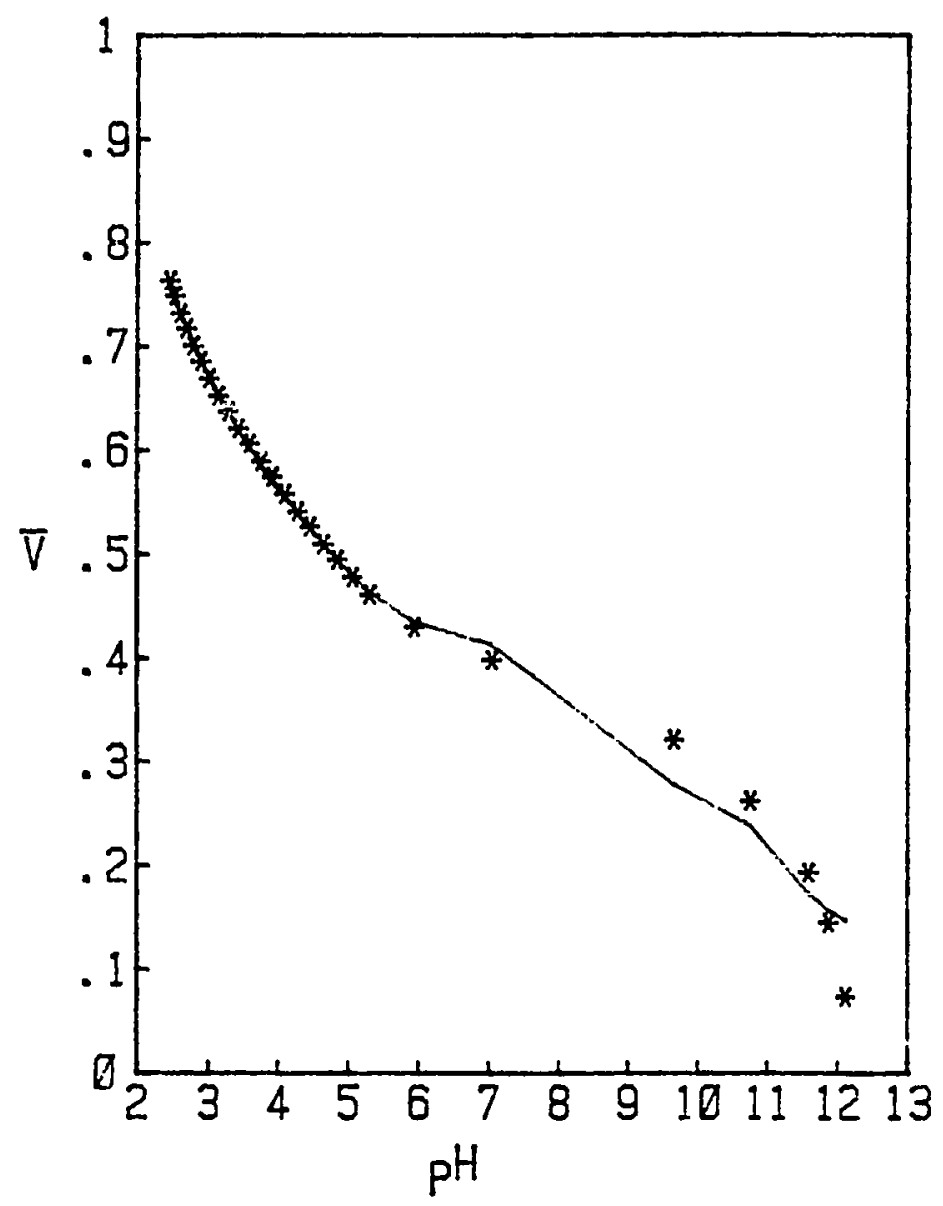

Figure 18. Experimental $\boldsymbol{\nabla}$ values $(*)$ and calculated fit $(\longrightarrow)$ for the bimodal Gaussian modeling of a proton titration of Williamson River humus. 
tiates the general utility of the model. A plot of the distribution from the $\mathrm{C}_{\mathrm{L}}=12.0$ fitting parameters is given in Fig. 19. The mean $\mathrm{pK}_{\mathrm{a}}$ values of the two classes of functional groups are consistent with the known properties of carboxyl groups $\left(\mu_{1}=2.54\right)$ and phenollc hydroxyl groups $\left(\mu_{2}=9.64\right)$, both of which are thought to be responsible for the acldic properties of humic substances (Stevenson and Butler, 1969; Schnitzer and Khan, 1972). The mean $\mathrm{pK}_{\mathrm{a}}$ of the phenolic group is lower than would be expected. This is again most probably due to the paucity of data in the inflection region of the titration curve. Finally, when the estimated total acidity ( 12.0 mols $\mathrm{H} / \mathrm{g}$ humus) is multiplied by theta, a carboxyl content of $5.3 \mathrm{mols} / \mathrm{g}$ is obtained. Although this value is slightly higher than expected (Perdue et al., 1980), it is not unreasonable.

The applicability of the Gausslan distribution model to copper binding by humlc substances was evaluated using two data sets for titration of humus with $\mathrm{Cu}(\mathrm{II})$ at $\mathrm{pH} 5.0$ and $\mathrm{I}=0.1 \mathrm{M} \mathrm{NaClO}{ }_{4}$. The first data set was obtalned in this laboratory using aquatic humus from the Williamson RIver, Oregon. The second data set was constructed from the Scatchard fitting parameters published by Sposito et al. (1979) for sewage sludge-derived fulvic acids (titration \#1 in their paper). Both data sets were fit reasonably well by a single-mode Gaussian distribution model (one class of ligands), although minor Improvement in the degree of fit was obtained with the bimodal distribution model.

The single-mode results are given in Fig. 20 and Fig. 21 for the Williamson River humus titration $(\mu=4.15, \sigma=1.20)$ and that of 


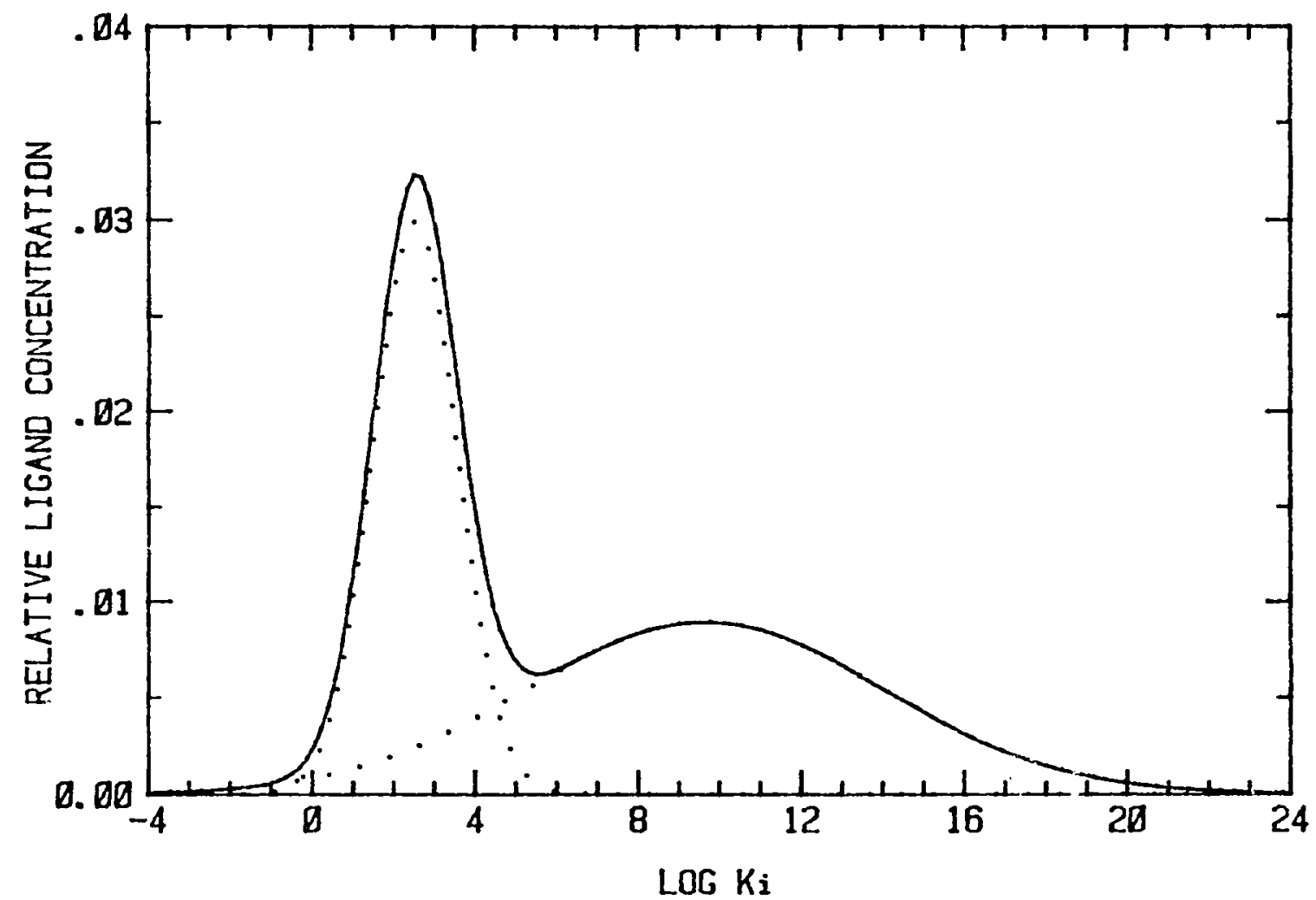

Figure 19. Bimodal Gaussian distribution that yielded the "best" fit for the proton-humus titration. 


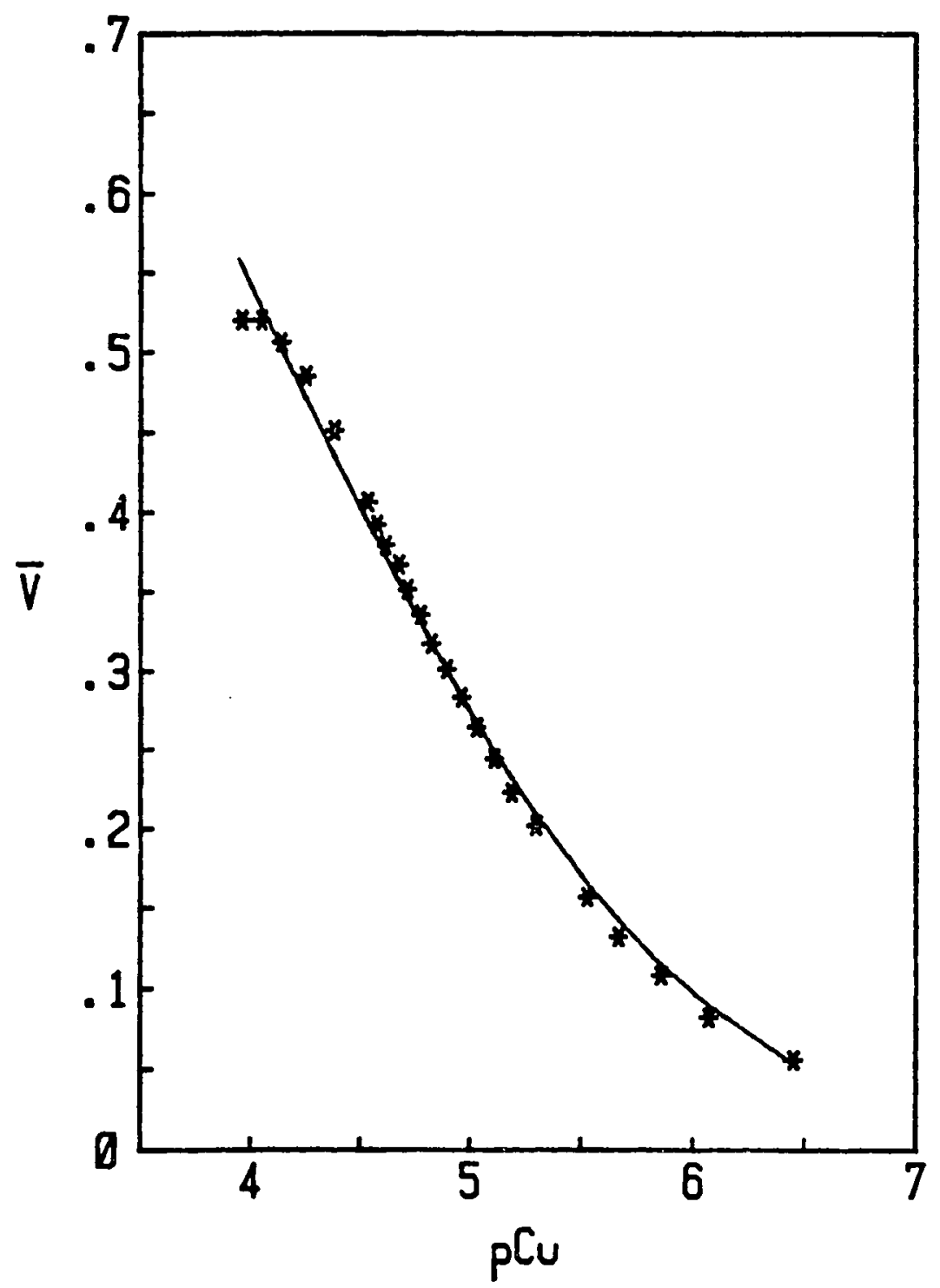

Figure 20. Experimental values $(*)$ and calculated fit ( $\longrightarrow$ ) using the Gaussian distribution model for a copper titration into Williamson River humus. 


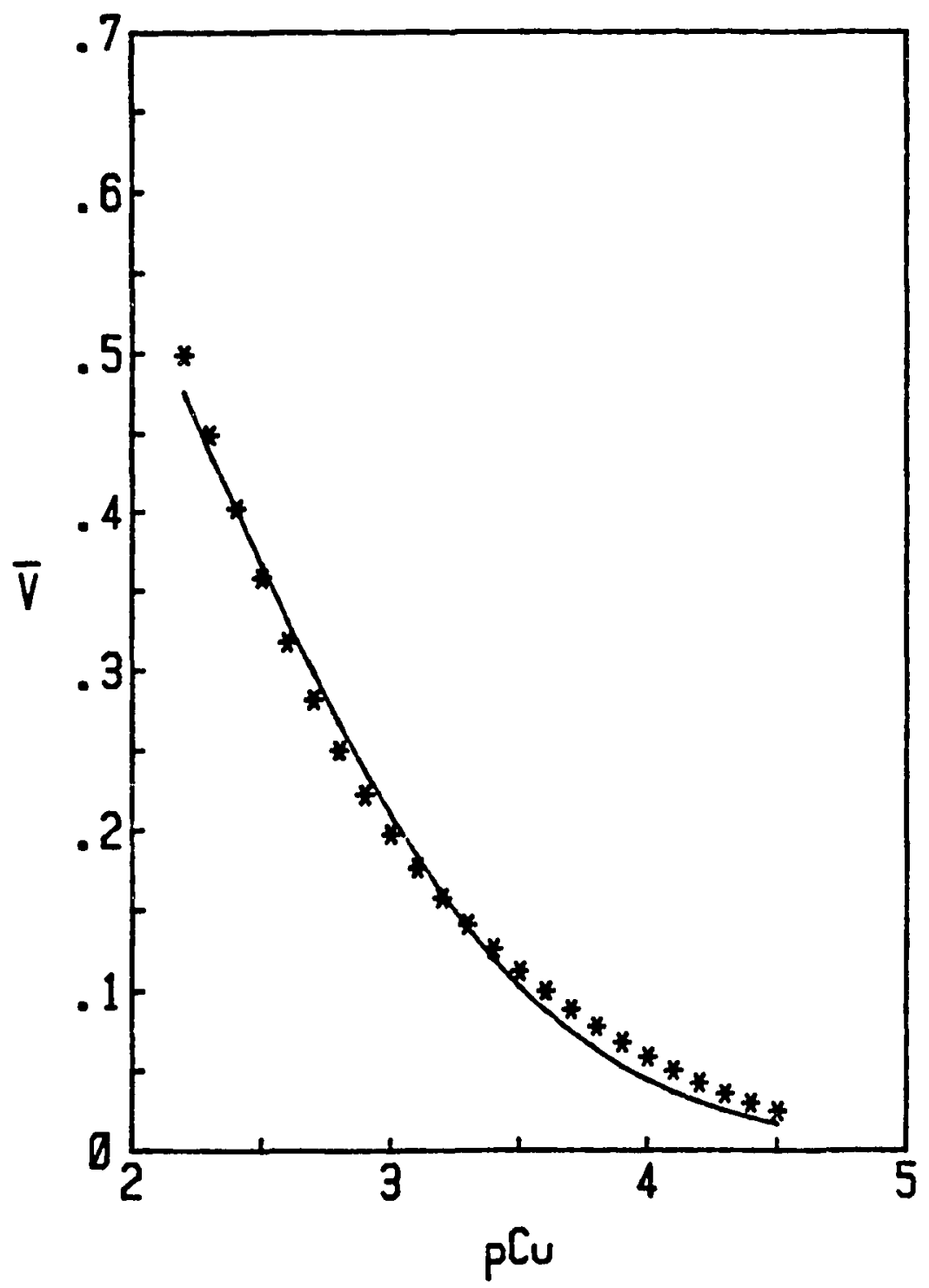

Figure 21. Data constructed from the Scatchard parameters of Sposito et al. (1979) (*) and calculated fit (—) using the Gaussian distribution model. 
Sposito et al. $(\mu=2.14, \sigma=0.76)$, respectively. In both cases, the agreement between calculated and experimental $\overline{\mathbf{v}}$ values is good. It is particularly gratifying to note that the "experimental" points in Fig. 21, which were generated using four fitting parameters in the twocomponent Scatchard equation, can be described quite well with the two fitting parameters of the Gaussian distribution model. The $\mu$ value for aquatic humus is much higher than that for sewage sludge derived fulvic acld. The relatively weaker affinity of the latter material for $\mathrm{Cu}$ (II) is also Indicated if the Scatchard parameters of Sposito et al. (1979) are compared with results of other workers on soll and water fulvic acids (e.g., Bresnahan et al., 1978). In both cases, the $\sigma$ values were relatively small, indicating that most $\mathrm{Cu}(\mathrm{II})$-binding ligands are roughly comparable in $\mathrm{Cu}(\mathrm{II})$-binding strength.

The exceedingly complex mixture of ligands that are involved In proton binding and metal binding by aquatic humus cannot be unambiguously described by any type of chemfcal model that is currently avallable. It is nevertheless possible to approximate the variation of $\bar{v}$ with $\left[\mathrm{H}^{+}\right]$or $[\mathrm{M}]$ using a varlety of chemical models, none of which is totally appropriate. Given the complexity of the ligand mixture, there can be no doubt that discrete models that postulate the existence of two or three distinct binding sites with unique equilibrium constants for proton or metal binding are fundamentally incorrect from both a chemical and a mathematical point of view. In contrast, continuous distribution models that postulate the existence of one or two classes of ligands whose Individual concentrations are a function of binding strength are at least consistent with the known complexity of the ligand 
mIxture.

Both proton and metal binding by aquatic humus are efficiently described by the Gaussian distribution model. Even data that were generated from the two-component Scatchard equation (with four fitting parameters) were successfully modeled using a Gausian distribution with two fitting parameters. In all 1ikelihood, this approach toward modeling the behavior of complex ligand mixtures in homogeneous solutions should also find application in studies of proton and metal binding in complex heterogeneous systems such as aqueous suspensions of particulate humic substances, amorphous metal oxides, etc.

\section{The Complexation Capacity of Williamson River Humus}

As in the case for proton binding, there is ambiguity in the definition of total ligand for metal binding to humic substances (Langford et a1., 1979). This ambiguity arises from the difficulty in assigning a molecular weight to the complex humic mixture. Researchers generally follow the procedure of Gachter et al. (1973) in which a sample of humus In titrated with metal. The titration is carried out until hopefully all the possible metal binding sites on the humic polymer are saturated. The data are plotted as free metal versus total metal, as shown in Fig. 22A. The resultant curve is nonlinear while the humus is complexing metal, but becomes linear after the humus is saturated with metal. This latter linear portion of the curve is extrapolated back to the $\mathrm{X}$-axis, and the $\mathrm{X}$-intercept is used as the operational definition of total ligand concentration as amount of metal bound per unit weight of humus. This method has been used in direct titrations (Chau et al., 1974; Ernst et al., 1975; Shuman and Woodward, 1977; Baccini and Suter, 
1979), dialysis titrations (Truitt and Weber, 1981), and ion-excnange titrations (Crosser and Allen, 1978). The data can also be presented as $\vec{v}$ or $\left(C_{M}-[M]\right)$ versus total metal (Gamble et al., 1980), as shown in Fig. 22B. The resultant curve approaches an asymptote as the humus becomes saturated. The asymptote is extrapolated back to the $\mathrm{Y}$-axis, and total ligand concentration is taken either directly as the intercept value or as the intercept divided by the weight of humus used.

Data for copper titrations Into Williamson River humus at $\mathrm{pH} 5.0$, $5.5,6.0$, and 6.5 and $I=0.1 \mathrm{M} \mathrm{NaClO}_{4}$ were analyzed using both the above procedures. The results, given in Table $\mathrm{x}$, clearly show that the

TABLE X

COMPARISON OF METHODS FOR ANALYZING COMPLEXATION CAPACITY DATA

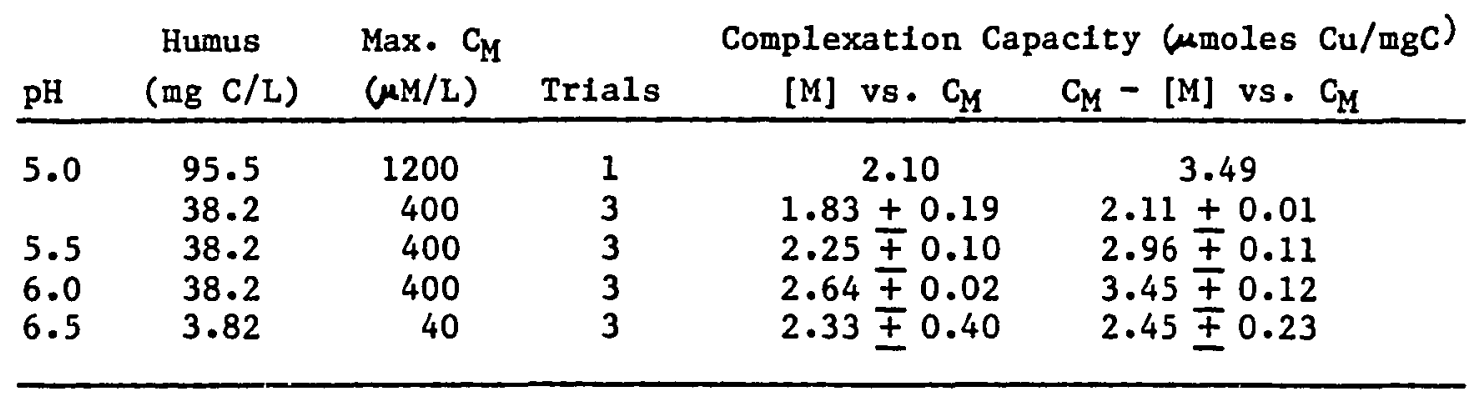

method of plotting free metal versus total metal gives lower estimates of total ligand than the method of plotting $\left(C_{M}-[M]\right)$ versus total wetal. This is explained by examining the data from the complexation capacity plots. In general, although the plots of free metal versus total metal appeared linear for high values of total metal (over 13 titrations, slope $=0.874 \pm 0.076$ and $r=0.9994 \pm 0.0003$ for the last 10 data 
points), $C_{M}-[M]$ was still increasing over most of these same, high total metal points. This is exemplified in Fig. 22, which shows data from titration $\# 2$ at $\mathrm{pH} 5.0$. The line extrapolated to the $\mathrm{X}$-axis in Fig. 22A has a slope of 0.980 and a correlation coefficient of 0.9997 and yields a complexation capacity of $1.69 \mu$ mols $\mathrm{Cu} / \mathrm{mg}$ humic carbon. The $C_{M}-[M]$ plot of this same data, shown in Fig. 22B, yields a value of 2.12 when fit on the SMPLX program (Appendix B). For the same range of metal added, the latter method allows a closer estimate of the complexation capacity. For this reason, the results from the former method were not considered.

Examination of the data in Table $X$ shows a dependence of the complexation capacity upon the total amount of humus in solution. The dependence of the degree of association for the general reaction $\mathrm{M}^{+}+\mathrm{A}^{-}=\mathrm{MA}$ is a fundamental concept of equilibrium chemistry, the rule beling that the fraction of total $M$ associated decreases as the concentration of MA decreases (Laitinen and Harris, 1975). The effect is 11lustrated in Fig. 23, which shows $\overline{\mathbf{v}}$ (complexation capacity) versus $\mathrm{C}_{\mathrm{M}} / \mathrm{C}_{\mathrm{L}}$ for a simple copper-oxalic acid binding reaction at three different concentrations of oxalic acid. As $C_{L}$ decreases, the curves flatten out at lower values of $\overline{\boldsymbol{v}}$, and any estimate of complexation capacity will decrease.

This fact has been overlooked in the study of aquatic humus. Since $\mathrm{C}_{\mathrm{L}}$ is used to determine the overall $\overline{\mathrm{K}}^{\prime}$ of metal hum binding reactions (Eq. 14 and 15), $\overline{\mathrm{K}}^{\prime}$ would be a function of total ligand concentration when $C_{L}$ is determined in this manner. This problem was found by Bufflé and co-workers, who postulated a number of hypothetical reactions to 


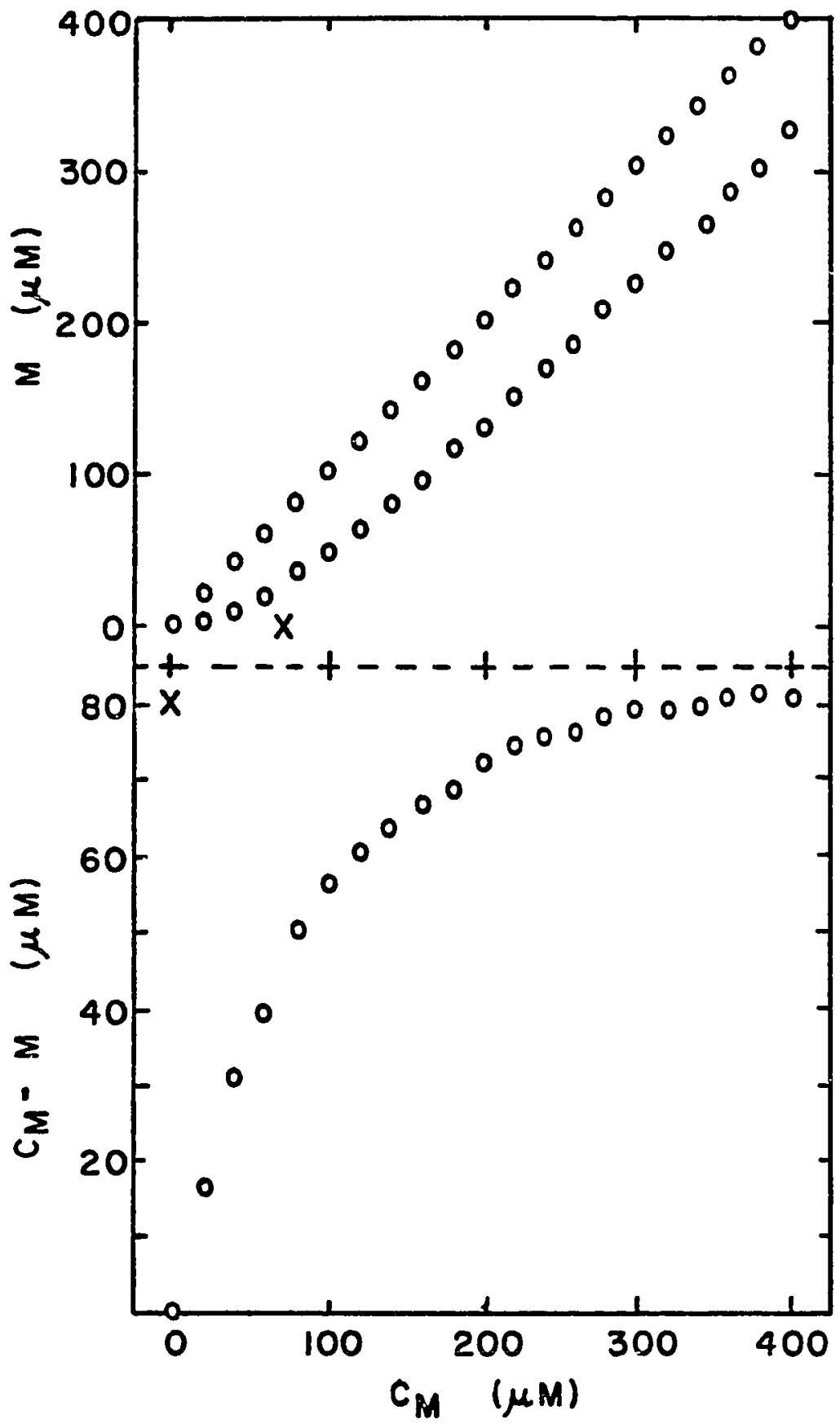

F1gure 22A, 22B. Complexation capacity of plots for $\mathrm{pH} 5$ titration \#2. Part A (top): free metal versus total metal. Part $B$ (bottom): $C_{M}-[M]$ versus total metal. $X=$ extrapolated complexation capacities. 


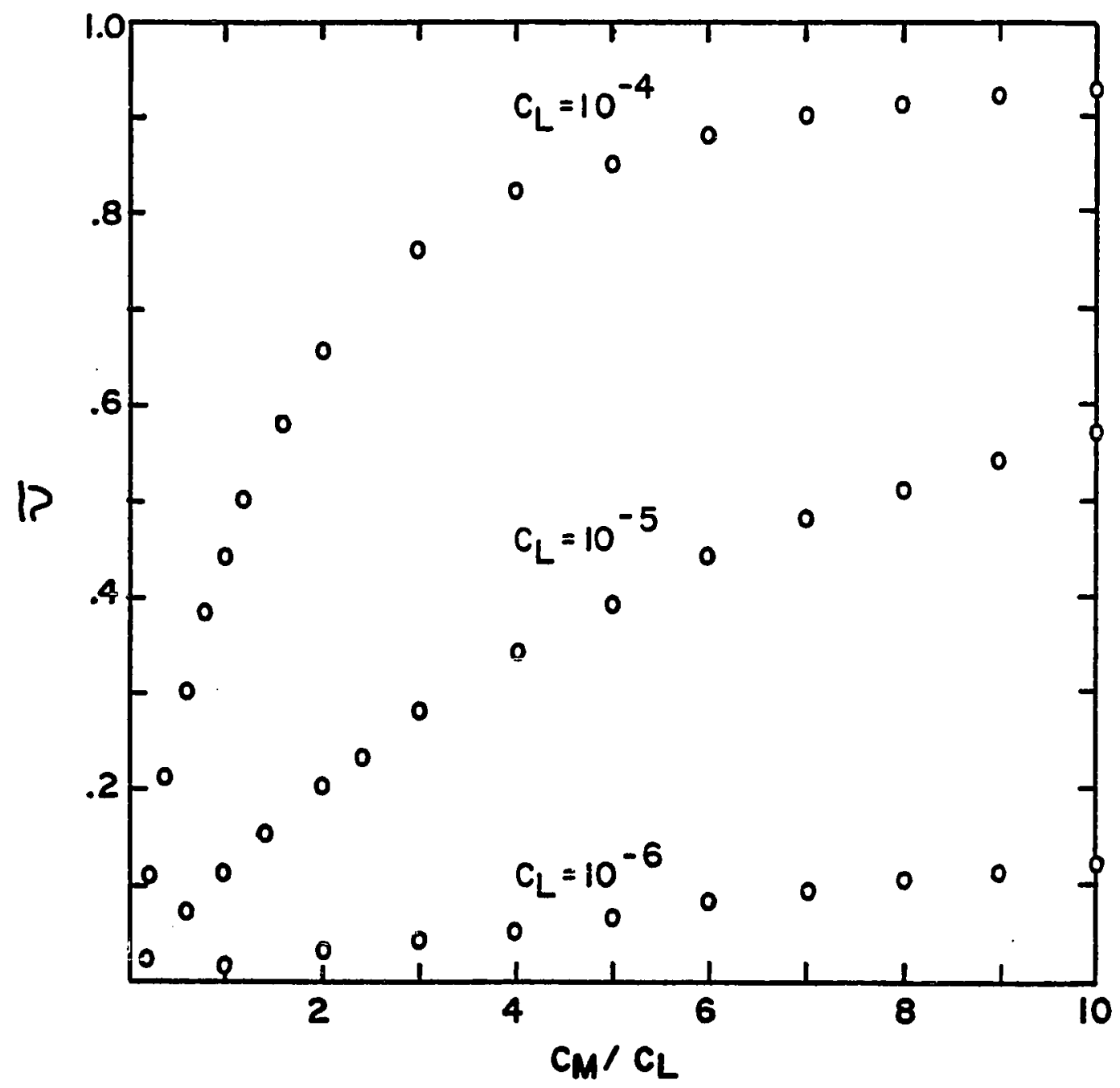

F1gure 23. $\bar{\sim}$ versus $C_{M} / C_{L}$ at various $C_{L}$ for copper binding to oxalic acid. 
explain variations in $\overline{\mathrm{K}}^{\prime}$ with $\mathrm{C}_{\mathrm{L}}$, none of which proved to be completely satisfactory. (See Chapter III discussion of discrete models and references therein.)

Thus the data in Table $X$ are not unexpected. If $\left(C_{M}-[M]\right)$ is normalized by dividing by the amount of humic carbon and plotted against free metal, the $C_{L}$ dependency is removed. This is shown, for all 13 complexation capacity titrations, in Fig. 24. Now the anomalously high $\mathrm{pH} 5$ titration is grouped with the other $\mathrm{pH} 5$ titrations, which were done at about one-third the value of $C_{L}$. Likewise, the $\mathrm{pH} 6.5$ data do not fall between the $\mathrm{pH} 5.0$ and 5.5 groups, as would be expected from the results in Table $X$. It should be noted that $C_{L}$ for Fig. 24 is defined as $g / L$ of humis carbon and that $C_{M}$ is corrected for the presence of hydroxide species by the use of a reagent blank titration. The curves in Fig. 24, which are of the same form of those in Fig. 18, 20, and 21, clearly show that, like the proton binding curve in Fig. 17, total ligand found is in reality the $\mathrm{X}$-axis value at the last titration point. Even though plots of the same data done as in Fig. 22B show a levelingoff, Fig. 24 clearly shows that this is not the case, and that any values for the complexation capacity obtained from such former plots are In error.

Given the analytical restraints on achleving high concentrations of free metal in solution at $\mathrm{pH}$ values close to natural waters conditions, titrations such as those shown in Fig. 24 cannot be continued to the point that the complexation capacity becomes a constant. It is true for a discrete 11gand and can be shown for a Gaussian distribution of ligands, that the inflection point in a plot of $\bar{v}$ versus $\log$ [M] occurs 


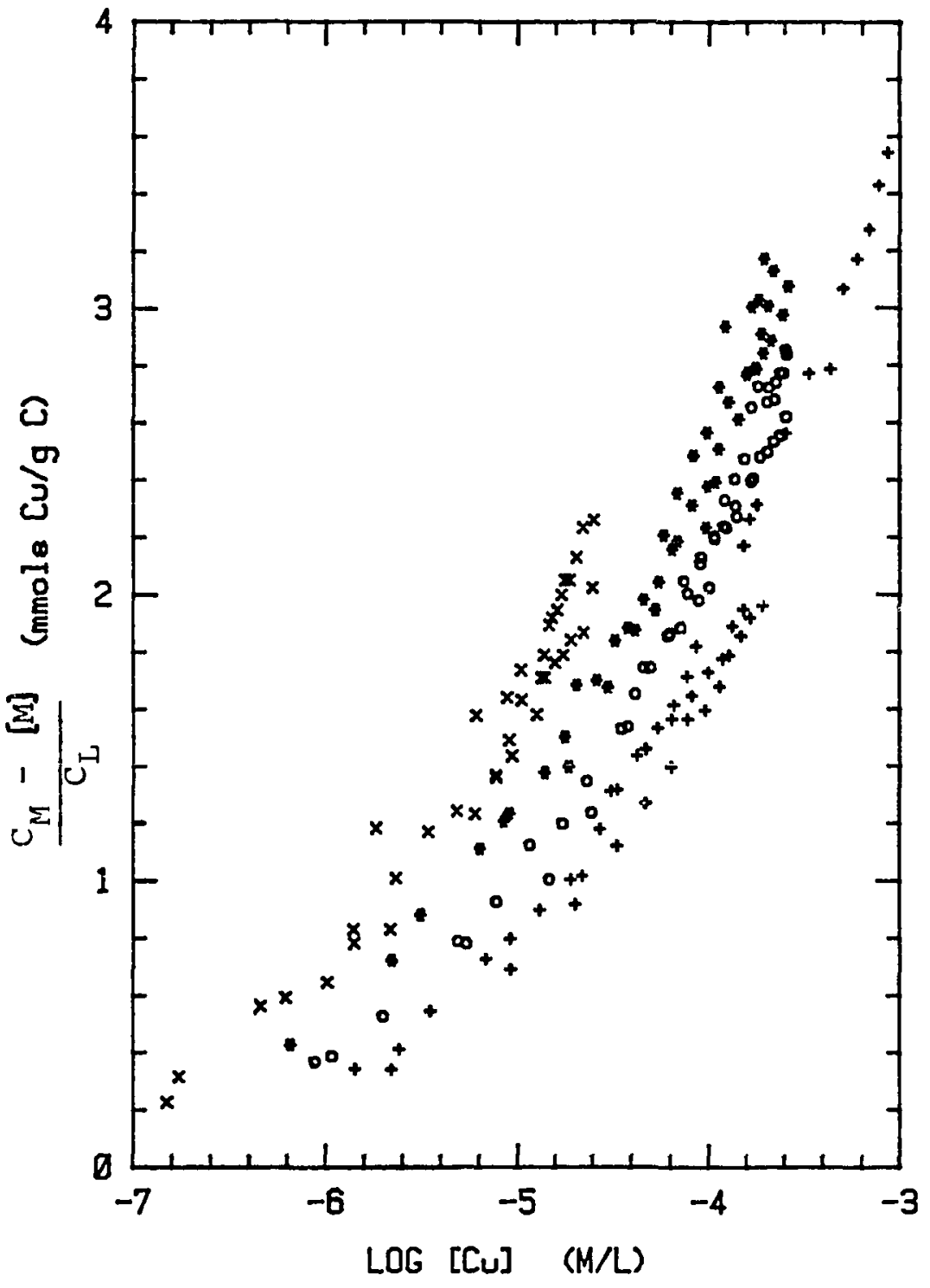

Figure 24. $\bar{v}$ versus $\mathrm{PM}$ for copper binding to Williamson River humus at $\mathrm{pH} 5.0(+), 5.5(0), 6.0(*), 6.5(\mathrm{x})$. 
at $\bar{v}=0.5$. If the highest value in F1g. 24 is taken as being close to this inflection point, twice this value is an estimate of the lowest posstble value for the complexation capacity. This lower estimate is then $7.2 \mu m o l s \mathrm{Cu} / \mathrm{mg}$ humic carbon. It was shown in the proton binding discussion that the estimated maximum total acidity for Williamson River humus is about 15.4 mols $\mathrm{H}^{+} / \mathrm{g}$ humus. Thus the esimated maximum complexation capacity would be $7.7 \mu$ mols $\mathrm{Cu} / \mathrm{g}$ humus, or $15.4 \mu \mathrm{mols} / \mathrm{mg}$ humic carbon. Thus the range would be $: 7.2 \leq \mathrm{C}_{\mathrm{L}} \leq 15.4$, in units of mmols $\mathrm{Cu} / \mathrm{mg}$ humic carbon. For the purposes of this research $\mathrm{C}_{\mathrm{L}}$ will be taken as the midpoint of this range, $11.3 \mu$ mols $\mathrm{Cu} / \mathrm{mg}$ humic carbon. It is important to note that $C_{L}$ is the concentration of all possible binding stes. The competition between protons and metal for these sites will be a function of $\mathrm{pH}$, but the value of $\mathrm{C}_{\mathrm{L}}$ will not be.

It was shown in Table IX that the bimodal fitting parameters are a function of $C_{L}$ when modeling humus proton binding. Since $C_{L}$ for copper binding must also be expressed as a range of possible values, the variation of the Gaussian fitting parameters with $C_{L}$ was investigated using simulated titrations generated from Gaussian fitting parameters obtalned from the copper-humus titration shown in Fig. 20. Titrations were simulated assuming a continuous Gaussian ligand distribution of $\mu=4.15$ and $\sigma=1.20 \mathrm{vfa}$ Eq. 16 and 23 . C C was inftially set at $2.0 \times 10^{-4}$ and increased to $2.0 \times 10^{-3}$. Each simulated titration was then fit to a single-mode Gausstan model. The results, shown in Fig. 25, show a significant sensitivity to $C_{L}$. For a two-fold increase in $C_{L}$ (the range expected from the above estimate), $\mu$ drops from 4.15 to 1.69 and $\sigma$ increases from 1.20 to 3.18 . Thus the fitting parameters 


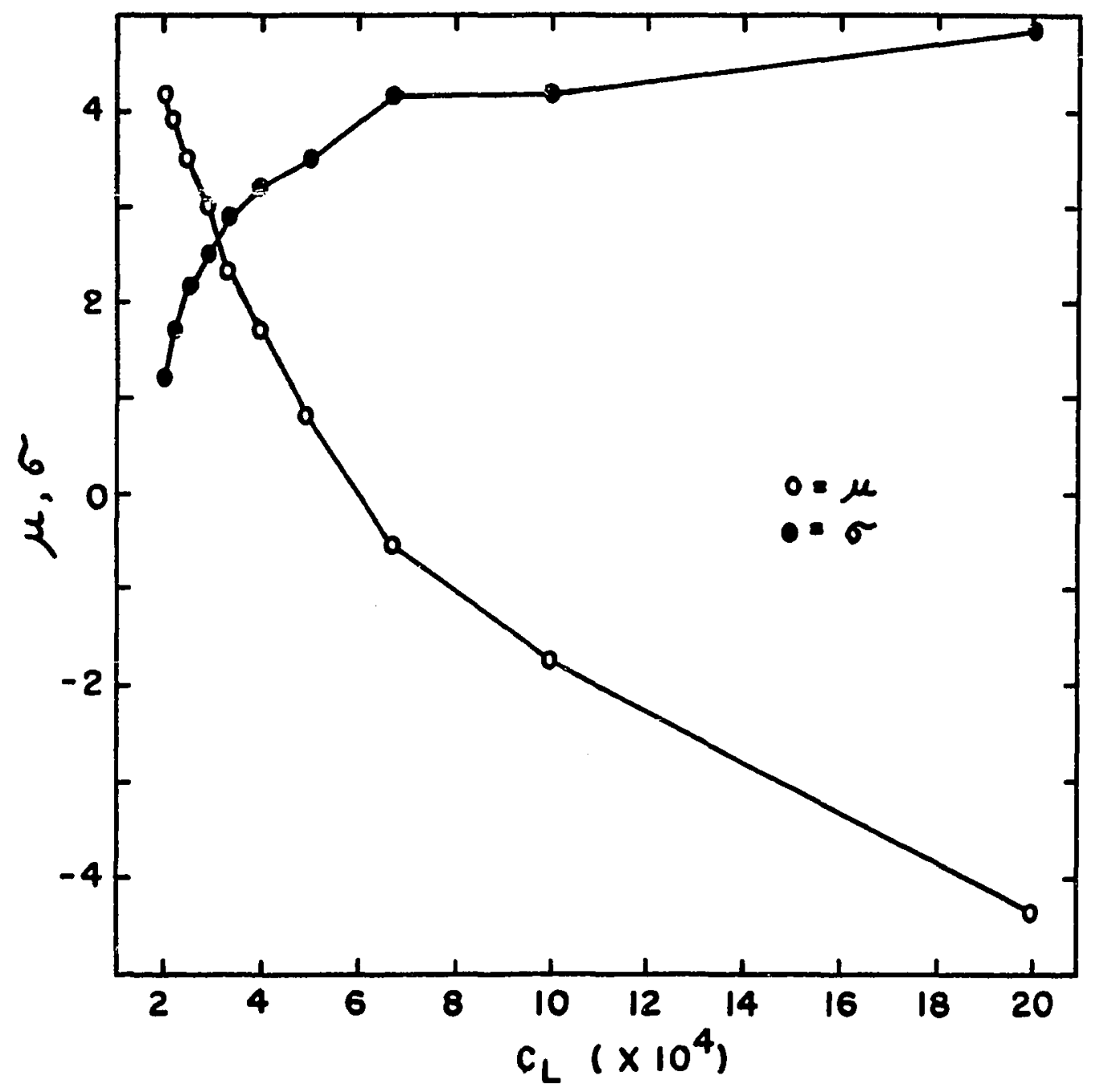

Figure 25. Variability in Gaussian fitting parameters with changes in $C_{L}$. Titrations simulated from a continuous Gaussian ligand distribution of $\mu=4.15, \sigma=1.20, \mathrm{C}_{\mathrm{L}}=2 \times 10^{-4} \mathrm{M}$. 
resulting from modeling $\bar{v}$ data in which $C_{L}$ is an estimated value must be Interpreted with care.

\section{Copper-Aquatic Humus Stability Function}

Determination of Copper-oxalate Binding Constants. The results for the three sets of three copper-oxalate titrations are given in Table XI. Although Student's t-test (Laitinen and Harris, 1975) may be applied to the $10^{-3} \mathrm{M}$ total oxalate data to show that the average result is statistically different from the other two averages, it was felt that the small number of experiments per each total oxalate concentration warranted that all nine determinations be considered as a single group.

TABLE XI

SMPLX DETERMINATIONS OF THE COPPER-OXALATE BINDING CONSTANTS

Total Oxalate $(\mathrm{M} / \mathrm{L})$ $\log \mathrm{K}_{1}$ $\log \beta_{2}$ Ave. $\log \mathrm{K}_{1}$ Av. $\log \beta_{2}$

$\begin{array}{lllll}10^{-3} & 5.43 & 9.83 & & \\ 10^{-3} & 5.43 & 9.82 & 5.42 \pm 0.01 & 9.83 \pm 0.01 \\ 10^{-3} & 5.41 & 9.83 & & \\ 10^{-4} & 5.78 & 10.25 & & \\ 10^{-4} & 5.74 & 10.34 & 5.76 \pm 0.02 & 10.27 \pm 0.06 \\ 10^{-4} & 5.77 & 10.23 & & \\ 10^{-5} & 5.88 & 10.98 & & \\ 10^{-5} & 6.07 & 10.53 & 5.99 \pm 0.10 & 10.71 \pm 0.24 \\ 10^{-5} & 6.01 & 10.63 & & \end{array}$


The overall averages calculated in this manner $\left(\log \mathrm{K}_{1}=5.72 \pm .25\right.$ and $\left.\log \beta_{2}=10.27 \pm 0.40\right)$ still vary over a much smaller range than values reported by Sillen and Martell (1964): $4.84-6.19$ for $\log k_{1}$ and $8.3-10.3$ for $\log \beta_{2}$.

Feasibility of the Copper-oxalate Metal Ion Buffer. A series of copper standards at $\mathrm{pH} 5.0$ and $25.01^{\circ} \mathrm{C}$ in $0.1 \mathrm{M} \mathrm{NaClO}{ }_{4}$ were run from $10^{-3} \mathrm{M}$ to $10^{-8} \mathrm{M}$ to determine a reasonable lower limit of linearity for the copper ISE. The results, shown in Figure 26, indicate a loss of linearity below $10^{-7} \mathrm{M}$. For the line from $10^{-3} \mathrm{M}$ to $10^{-7} \mathrm{M}$, the slope $=$ 29.04, intercept $=271.1$, and $r=0.9999$. (Theoretical slope at $25.01^{\circ} \mathrm{C}$ is 29.58.) Thus it was felt that a copper, metal ion buffer with total copper equal to $10^{-7} \mathrm{M}$ satisfied the requirement that, in order for response to be linear in the buffer system, total metal must be within the linear operating range of ISE in an unbuffered solution (Blaedel and Dinwiddie, 1974).

Since a total copper of $10^{-7} \mathrm{M}$ would be at the extreme edge of ISE linear response, it was decided to test the linearity of the buffer system itself by comparing free copper as measured in an oxalate-into$10^{-7} \mathrm{M}$ copper titration and as calculated for the same total copper and oxalate concentrations. The results, given in Table XII, show agreements to within about $1.2 \%$ for the range of free copper expected. Aquatic Humus Titrations into Copper Metal Ion Buffers. For the oxalate-copper buffer system, the appropriate mass balances (neglecting charges) are

$$
\mathrm{C}_{\mathrm{M}}=[\mathrm{Cu}]+[\mathrm{CuOX}]+[\mathrm{CuHOX}]+\left[\mathrm{Cu}(\mathrm{OX})_{2}\right]+[\mathrm{CuOH}]+[\mathrm{CuL}]
$$




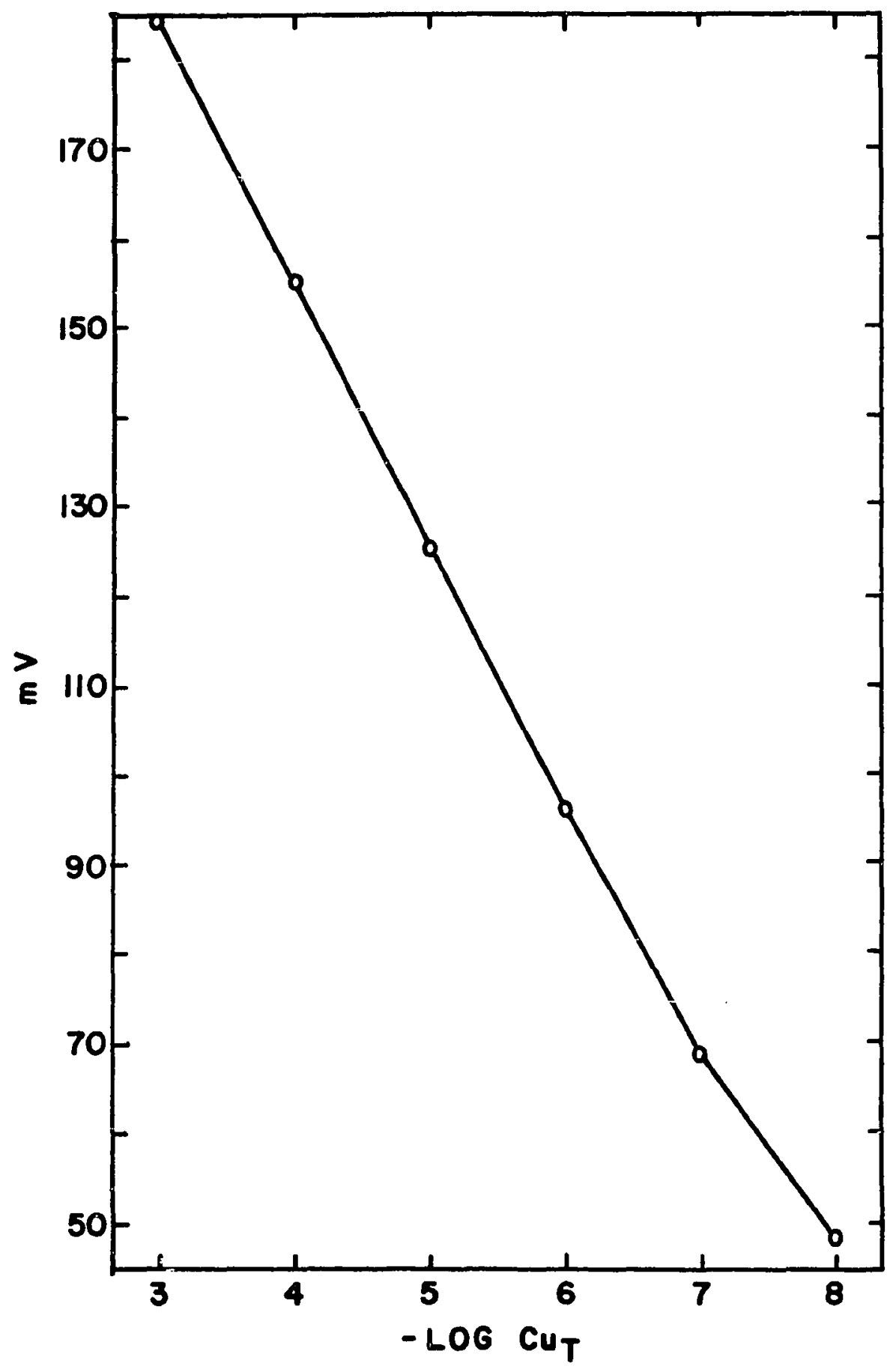

Figure 26. Copper ISE response for $10^{-3} \mathrm{M} \geq[\mathrm{Cu}] \geq 10^{-8}$, $\mathrm{pH} 5.0, \mathrm{I}=0.1 \mathrm{M} \mathrm{NaClO}_{4}$. 
TABLE XII

CALCULATED AND FOUND FREE COPPER CONCENTRATIONS FOR A COPPEROXALATE METAL ION BUFFER WITH $C_{M}=10^{-7} \mathrm{M}$

\begin{tabular}{cccc}
$\begin{array}{c}\text { Oxalate Conc. } \\
(\mathrm{M} / \mathrm{L})\end{array}$ & $\begin{array}{c}\mathrm{pCu} \text { CaIc. } \\
(\mathrm{M} / \mathrm{L})\end{array}$ & $\begin{array}{c}\mathrm{pCu} \text { Expt., } \\
(\mathrm{M} / \mathrm{L})\end{array}$ & $\begin{array}{c}\mathrm{pCu} \text { Expt., } \\
(\mathrm{M} / \mathrm{L})\end{array}$ \\
\hline 0 & -- & 6.91 & 6.93 \\
$1 \times 10^{-5}$ & 7.80 & 7.91 & 7.88 \\
$5 \times 10^{-5}$ & 8.74 & 8.66 & 8.68 \\
$1 \times 10^{-4}$ & 9.24 & 9.19 & 9.21 \\
$5 \times 10^{-4}$ & 10.54 & 10.44 & 10.47 \\
$1 \times 10^{-3}$ & 11.12 & 11.06 & 11.07 \\
\hline
\end{tabular}

$$
\mathrm{C}_{\mathrm{OX}}=[\mathrm{OX}]+[\mathrm{HOX}]+\left[\mathrm{H}_{2} \mathrm{OX}\right]+[\mathrm{CuOX}]+[\mathrm{CuHOX}]+2\left[\mathrm{Cu}(\mathrm{OX})_{2}\right]
$$

where CuL is the copper-humus complex and where the mixed ligand complex $\mathrm{Cu}(\mathrm{OX}) \mathrm{L}$ is omfticed. The $\log \mathrm{K}$ values for each of the species formation reactions is given in Table XIII. All values are from Sillen and Marte11 (1964) except $\log \mathrm{K} 1$ and $\log \mathrm{K} 2$, which are from th1s research. Substituting the appropriate equilibrium expressions into Eq. 28 and rearranging, a quadratic in [OX] is obtained:

$$
(2[\mathrm{Cu}] \mathrm{K} 2)[\mathrm{OX}]^{2}+\left(1+[\mathrm{H}] \mathrm{Ka}_{1}+[\mathrm{H}]^{2} \mathrm{Ka}_{2}+[\mathrm{Cu}] \mathrm{K} 1+[\mathrm{Cu}][\mathrm{H}] \mathrm{K} 3\right)[\mathrm{OX}]-\mathrm{COX}=0
$$

The resultant value for [OX] is inserted in the copper mass balance equation, which is solved for [CuL]:

$$
[\mathrm{CuL}]=\mathrm{C}_{\mathrm{M}}-\left(1+[\mathrm{OX}] \mathrm{K} 1+[\mathrm{OX}]^{2} \mathrm{~K} 2+[\mathrm{H}][\mathrm{OX}] \mathrm{K} 3+[\mathrm{OH}] \mathrm{K} 4\right)[\mathrm{Cu}]
$$


TABLE XIII

FORMATION RACTIONS AND CONSTANTS

FOR THE COPPER-OXALATE METAL ION BUFFER

\begin{tabular}{lcc} 
Reaction & Constant & Log Constant \\
\hline $\mathrm{H}+\mathrm{OX}=\mathrm{HOX}$ & $\mathrm{Ka}_{1}$ & 3.81 \\
$2 \mathrm{H}+\mathrm{OX}=\mathrm{H}_{2} \mathrm{OX}$ & $\mathrm{Ka}_{2}$ & 5.18 \\
$\mathrm{Cu}+\mathrm{OX}=\mathrm{CuOX}$ & $\mathrm{K} 1$ & 5.72 \\
$\mathrm{Cu}+2 \mathrm{OX}=\mathrm{Cu}(\mathrm{OX})_{2}$ & $\mathrm{~K} 2$ & 10.27 \\
$\mathrm{Cu}+\mathrm{H}+\mathrm{OX}=\mathrm{CuHOX}$ & $\mathrm{K} 3$ & 6.30 \\
$\mathrm{Cu}+\mathrm{OH}=\mathrm{CuOH}$ & $\mathrm{K} 4$ & 5.91 \\
\hline
\end{tabular}

where $[\mathrm{OH}]=\mathrm{KW} /[\mathrm{H}]$. Equation 31 is then solved for the overall conditiona]. stability constant at each titration point, where [Cu] is measured experimentally, [CuL] is calculated as above, and $C_{L}$ is the complexation of capacity of Williamson River humus $\left(1.13 \times 10^{-5}\right.$ moles $\mathrm{Cu} / \mathrm{mg}$ humic carbon) times the humus content of the concentrated titrant $(4.5 \mathrm{~g} \mathrm{C} / \mathrm{L})$, corrected for dilution:

$$
\bar{k}^{\prime}=\frac{[\mathrm{CuL}]}{[\mathrm{Cu}]\left(\mathrm{C}_{\mathrm{L}}-[\mathrm{CuL}]\right)}
$$

One additional factor is that the freeze-dried humus itself contalns copper. The $4.5 \mathrm{~g} \mathrm{C} / \mathrm{L}$ titrant was diluted $1: 10$ and measured for copper content by graphite furnance AAS. Quadruplicate analyses gave a copper concentration of $21.79 \pm 2.22 \mathrm{PPB}$, or $3.43 \times 10^{-6} \mathrm{M}$ in the original solution. Thus $C_{M}$ must be corrected for this additional input of 
copper at each titration point. At the beginning of the titration, this additional copper is a small correction $\left(1.7 \times 10^{-9} \mathrm{M}\right)$ but becomes significant in the latter points $\left(3.40 \times 10^{-8} \mathrm{M}\right.$ at point $\# 20$ and $6.72 \mathrm{X}$ $10^{-8} \mathrm{M}$ at point $\# 40$ ).

Plots of $\log \overline{\mathrm{K}}^{\prime}$ versus $\log C_{L} / C_{M}$ are given in Figures 27-30 for the duplicate titrations at $\mathrm{pH} 5.0,5.5,6.0$, and 6.5, and a composite plot of 4 titrations, one at each $\mathrm{pH}$, is shown in Fig. 31. Clearly, the log $\overrightarrow{\mathrm{k}}^{\prime}$ values do not become constant, even at a ligand:metal ratio of over 5300. (The average 11 gand metal ratio, corrected for 1ron, at WR-50, the most humus-rich site on the Williamson River, is about 4300 , using a complexation capacity of $1.13 \times 10^{-5}$ moles $\mathrm{Cu} / \mathrm{mg}$ humlc carbon and the DOM and iron vilues reported by Perdue et al. (1981)).

All elght of the copper, metal-ion buffer titrations were fitted with the Gaussian model. The results are summarlzed in Table XIV. Examlnation of the PHI values shows that the bimodal model gave a small enhancement of fit for the $\mathrm{pH} 6.0$ and 6.5 titrations and no significant improvement of fit to the $\mathrm{pH} 5.0$ and 5.5 titrations. Also, Student's t-test (Laitinen and Harris, 1975) showed that only the means for the bimodal fit at $\mathrm{pH} 5.0$ were significantly different at the $95 \%$ confidence level. For these reasons, it was felt that the addition of three more fitting parameters with the bimodal model was not justifled and that the single-mode fits were adequate. The average single-mode parameters Indicate a small increase in $\mu$ and a slightly greater increase in $\sigma$ with increasing $\mathrm{pH}$. This trend is interpreted as the gradually increasing complexation of copper to weaker binding sites as the competition with hydrogen ion for these sites lessens. The shift in $\mu$ is small because 


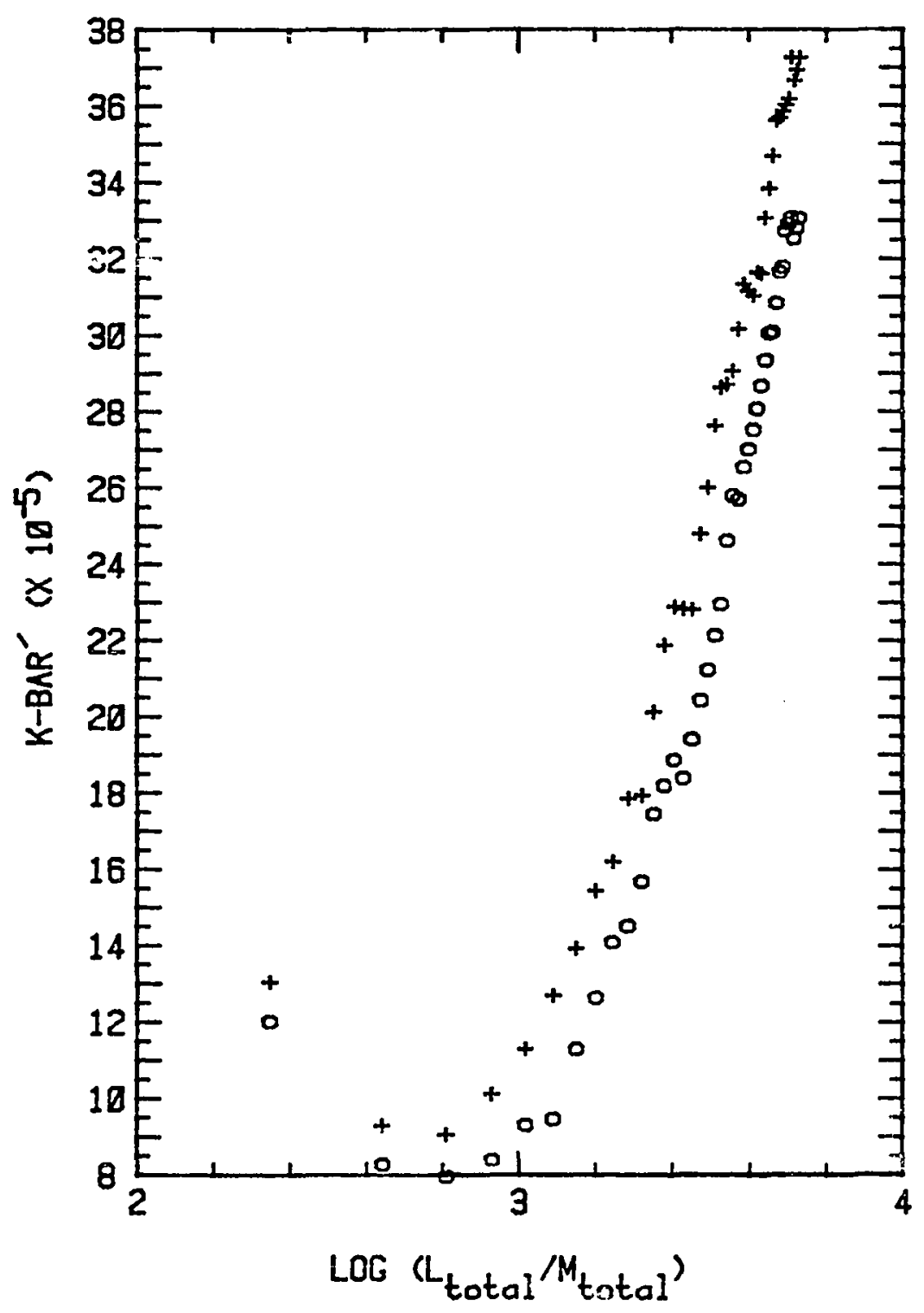

Figure 27. $\quad \overline{\mathrm{K}}^{\prime}$ versus $\log \mathrm{C}_{\mathrm{L}} / \mathrm{C}_{\mathrm{M}}$ at $\mathrm{pH} 5.0$. 


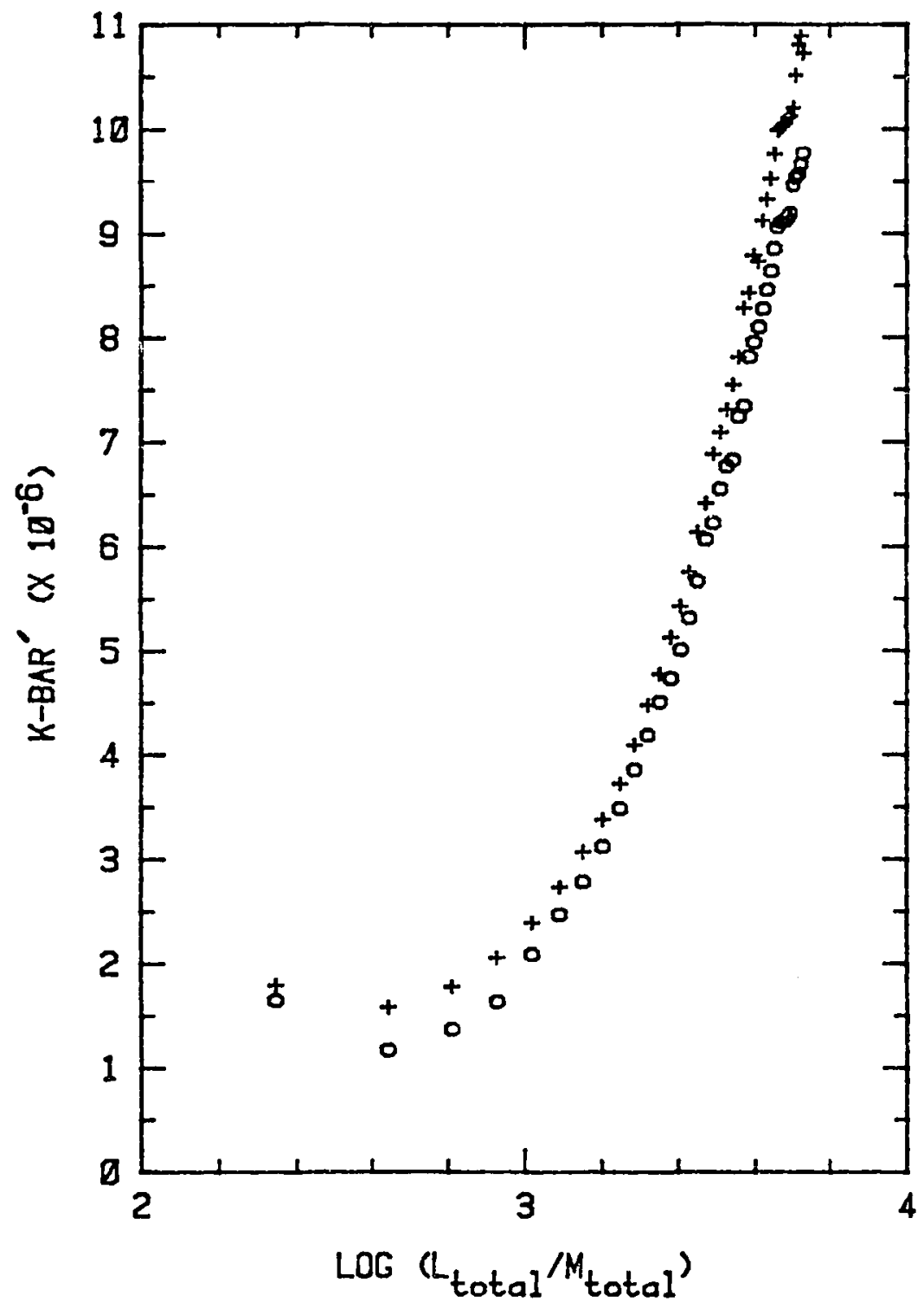

Figure 28. $\quad \overline{\mathrm{K}}^{\prime}$ versus $\log \mathrm{C}_{\mathrm{L}} / \mathrm{C}_{\mathrm{M}}$ at $\mathrm{pH} 5.5$. 


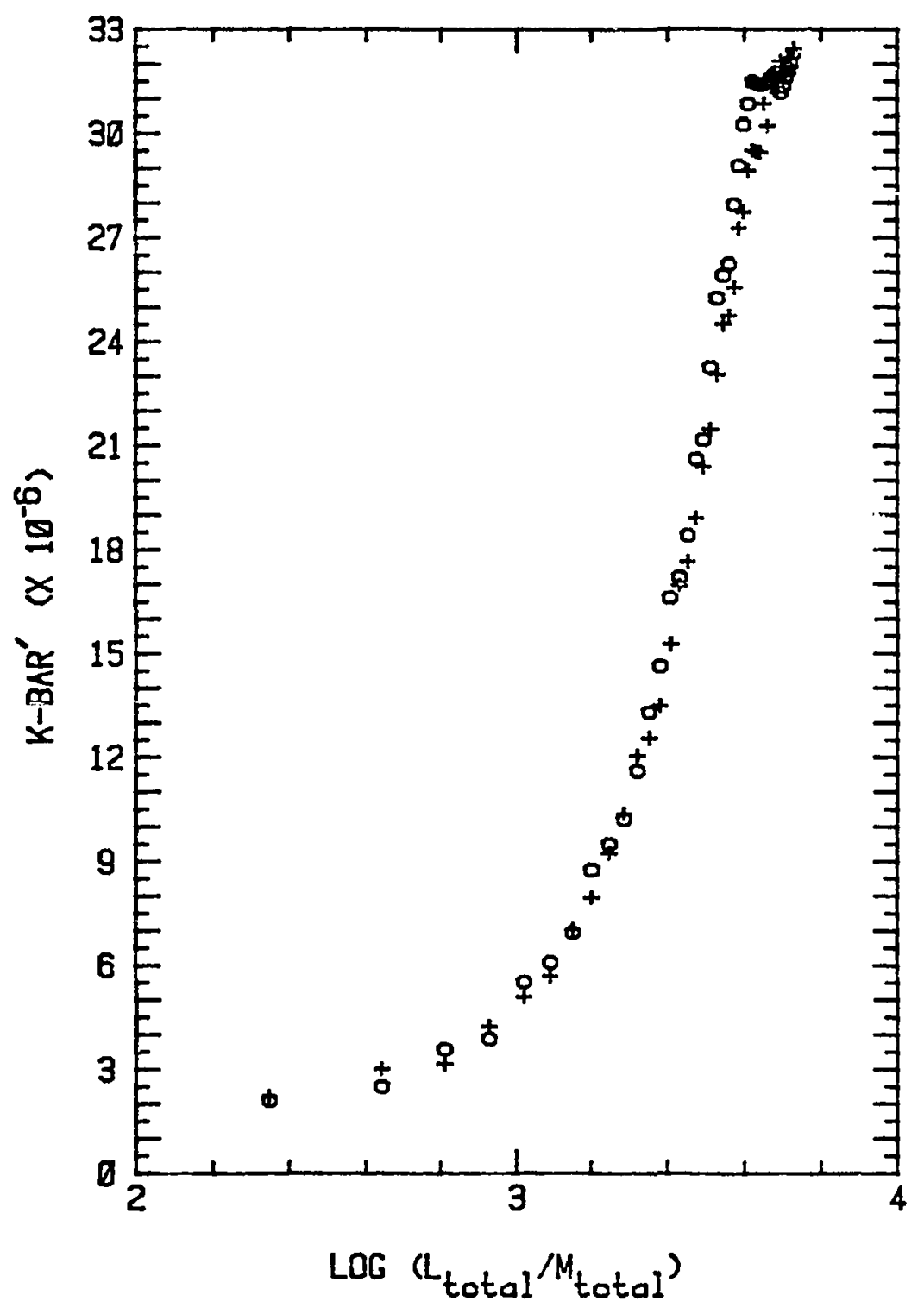

F1gure 29. $\overline{\mathrm{K}}^{\prime}$ versus $\log \mathrm{C}_{\mathrm{L}} / \mathrm{C}_{\mathrm{M}}$ at $\mathrm{pH} 6.0$. 


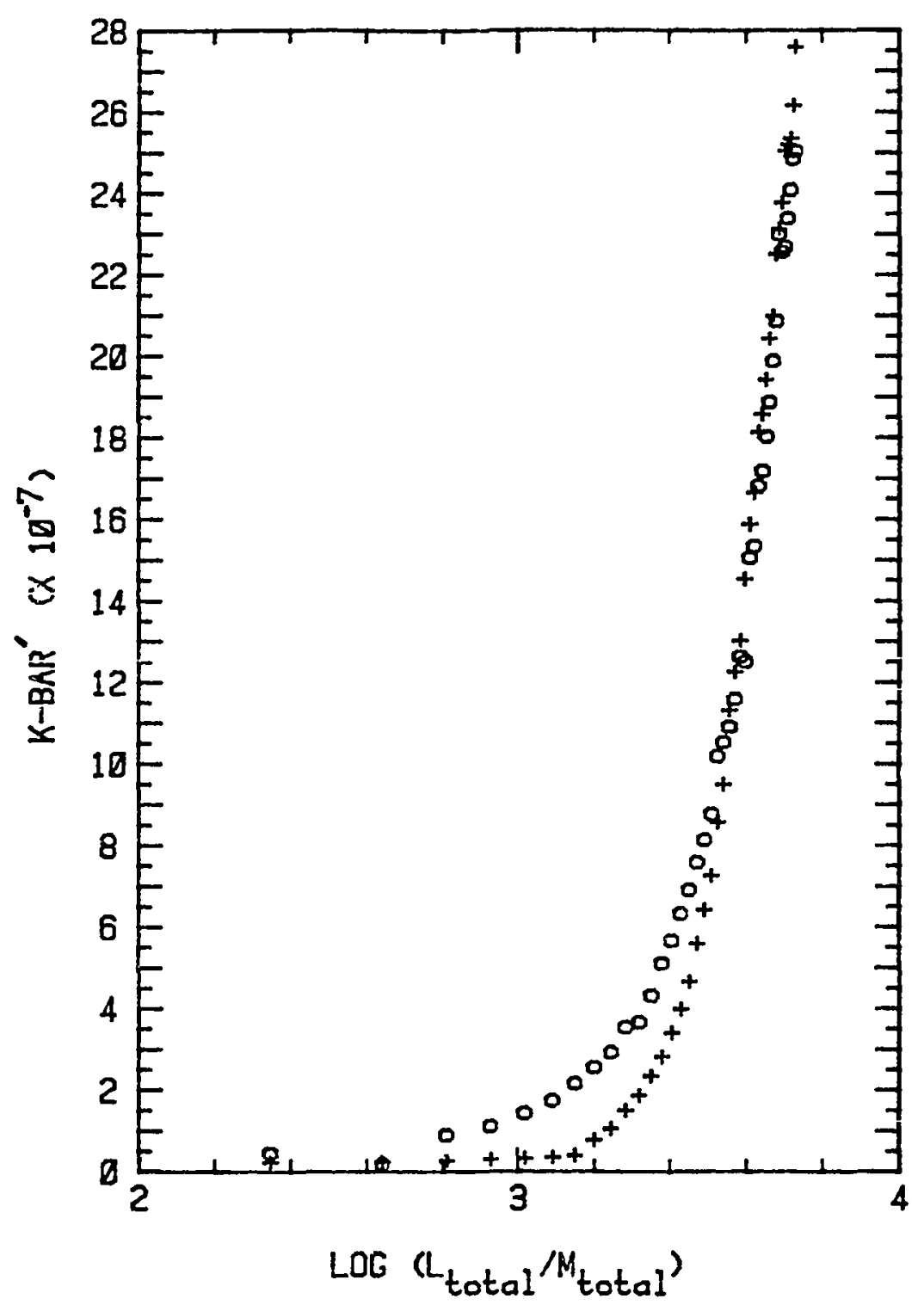

Figure 30. $\quad \overline{\mathrm{K}}^{\prime}$ versus $\log \mathrm{C}_{\mathrm{L}} / \mathrm{C}_{\mathrm{M}}$ at $\mathrm{pH} 6.5$. 


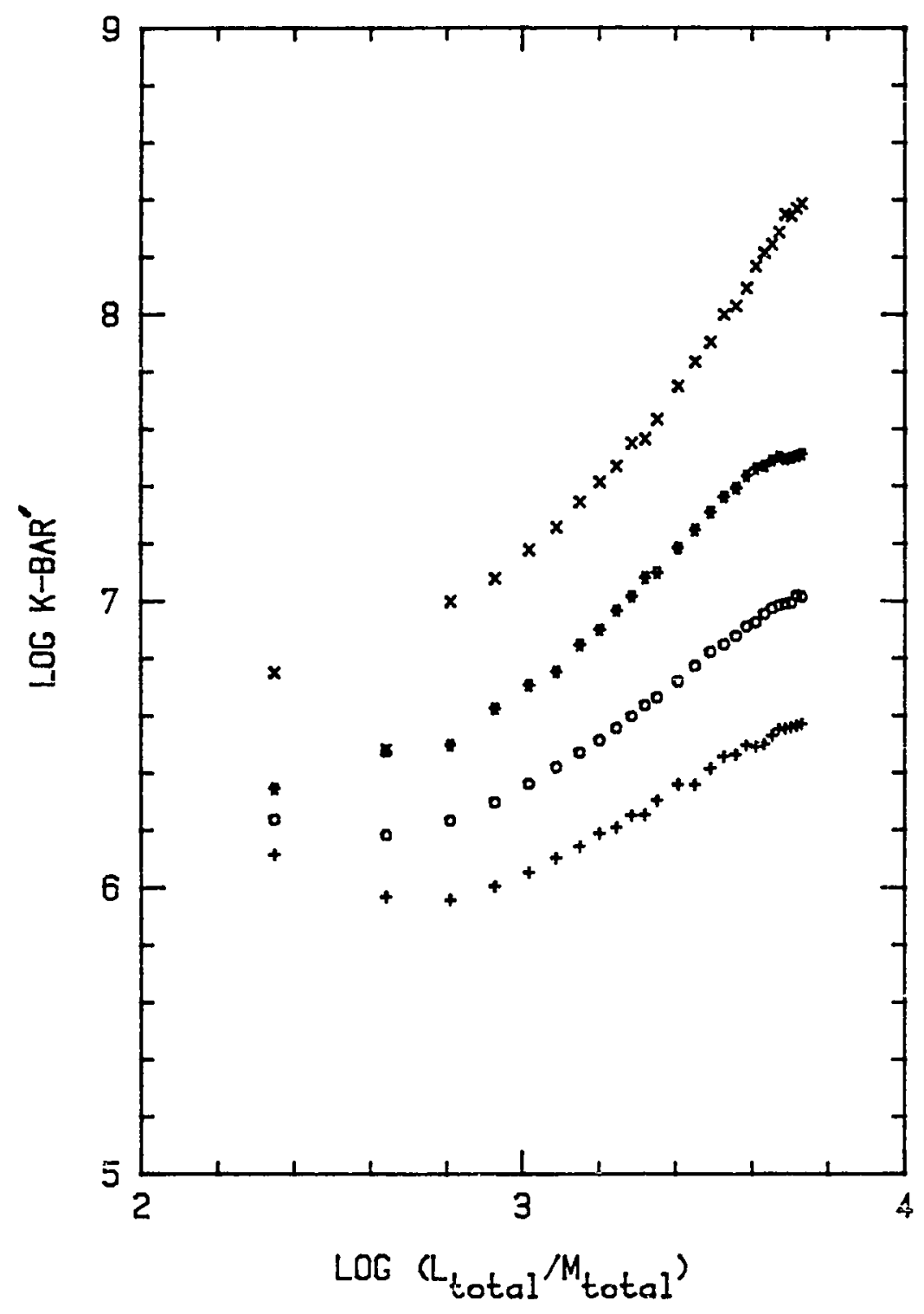

Figure 31. Log $\overline{\mathrm{K}}^{\prime}$ versus $\log \mathrm{C}_{\mathrm{L}} / \mathrm{C}_{\mathrm{M}}$. One titration each at $\mathrm{pH} 5.0(t), 5.5(0), 6.0(*)$, and $6.5(\mathrm{x})$. 
TABLE XIV

FITTING PARAMETERS FOR THE SINGLE AND BIMODAL GAUSSIAN MODELING OF THE COPPER, METAL-ION BUFFER TITRATIONS

\begin{tabular}{|c|c|c|c|c|c|c|c|c|c|c|}
\hline & \multirow[b]{2}{*}{ Trial } & \multicolumn{3}{|c|}{$\begin{array}{l}\text { Single-Mode } \\
\text { PHI* }\end{array}$} & \multicolumn{3}{|c|}{ Bimodal } & \multirow[b]{2}{*}{$\sigma_{1}$} & \multirow[b]{2}{*}{$\mu_{2}$} & \multirow[b]{2}{*}{$\sigma_{2}$} \\
\hline & & $\mu$ & $\sigma$ & $\left(x 10^{6}\right)$ & $\left(x 10^{6}\right)$ & $\theta$ & $\mu_{1}$ & & & \\
\hline \multirow[t]{2}{*}{5.0} & 1 & 3.81 & 1.52 & 2.2 & 1.9 & 0.06 & 3.11 & 1.56 & 4.68 & 1.16 \\
\hline & 2 & 3.81 & 1.50 & 2.6 & 2.2 & 0.10 & 3.11 & 1.54 & 4.68 & 1.14 \\
\hline \multirow[t]{2}{*}{5.5} & 1 & 3.81 & 1.62 & 1.2 & 0.9 & 0.30 & 3.72 & 1.88 & 4.91 & 0.97 \\
\hline & 2 & 3.97 & 1.52 & 2.0 & 1.2 & 0.02 & 3.91 & 2.67 & 5.13 & 0.92 \\
\hline \multirow[t]{2}{*}{6.0} & 1 & 3.98 & 1.62 & 1.3 & 0.5 & 0.22 & 3.98 & 2.04 & 4.38 & 1.13 \\
\hline & 2 & 4.01 & 1.62 & 1.5 & 0.6 & 0.28 & 4.00 & 1.98 & 4.01 & 1.12 \\
\hline \multirow[t]{2}{*}{6.5} & 1 & 3.99 & 1.59 & 2.5 & 2.2 & 0.22 & 3.96 & 1.95 & 4.08 & 1.34 \\
\hline & 2 & 4.01 & 1.80 & 1.5 & 0.5 & 0.20 & 4.00 & 2.27 & 4.01 & 1.47 \\
\hline 5.0 & & 3.81 & 1.51 & 2.4 & 2.0 & 0.08 & 3.11 & 1.55 & 4.68 & 1.15 \\
\hline 5.5 & & 3.89 & 1.57 & 1.6 & 1.0 & 0.16 & 3.82 & 2.28 & 5.02 & 0.94 \\
\hline 6.0 & & 4.00 & 1.62 & 1.4 & 0.6 & 0.25 & 3.99 & 2.01 & 4.20 & 1.11 \\
\hline 6.5 & & 4.00 & 1.70 & 2.0 & 0.8 & 0.21 & 3.98 & 2.11 & 4.04 & 1.40 \\
\hline
\end{tabular}

* PHI is the weighted sum over all data points of the squares of residuals. See Appendix $C$. 
the strong binding sites still dominate the overall distribution. The shift in $\sigma$, then, reflects this increase in weak binding sites by broadening the distribution. This broadening is double-sided because of the symmetry constraint inherent in the Gaussian distribution and is not consistent with a distribution increase to only the high side of $\mu$. This problem can be overcome through the use of a nonsymetrical distribution model (Parrish, 1982).

Examples of the calculated fits are given in Figures 32-35 for the titrations used in Fig. 31. The model appears to fit the metal ion buffer titration data less well than the data shown in Fig. 20 and 21 . However, the Y-axes in Fig. 32-35 are actually magnified 10 times the Y-axes in Fig. 20-22. Thus, similar absolute differences would appear to be 10 times as great in the metal-ion buffer plots. The fits did not improve for a thousand-fold reduction in the convergence criterion. (See Appendix C.)

Comparison of the metal-ion buffer results with the literature is difficult because experimental data are interpreted via discrete models and results are in the form of tabulated constants generated from these models. Since such constants have been shown in this research to be only curve-fitting parameters, they are not directly comparable to the functions shown in Fig. 27-30.

One possible method of comparison is to regenerate raw titration data from tabulated fitting parameters. For Scatchard parameters, Eq. 18 may be used directly. For parameters derived by other methods, such as the multiple-stoichiometry model, similar equations specific to 


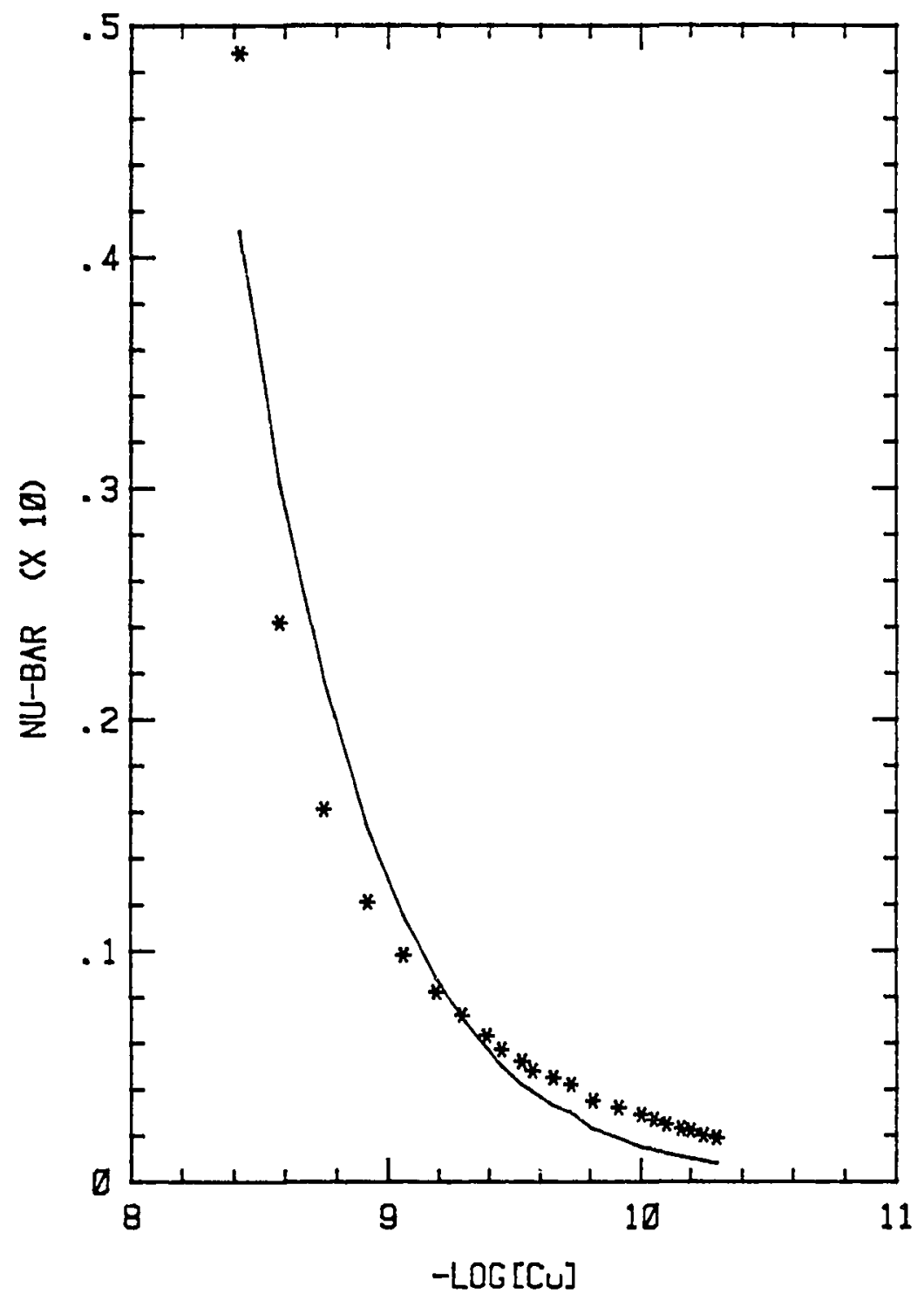

Figure 32. Experimental data (*) and calcilated fit (-) for the single mode Gaussian modeling of the pH 5.0 metal Ion buffer titration \#1. Fitting parameters given in Table XIV. 


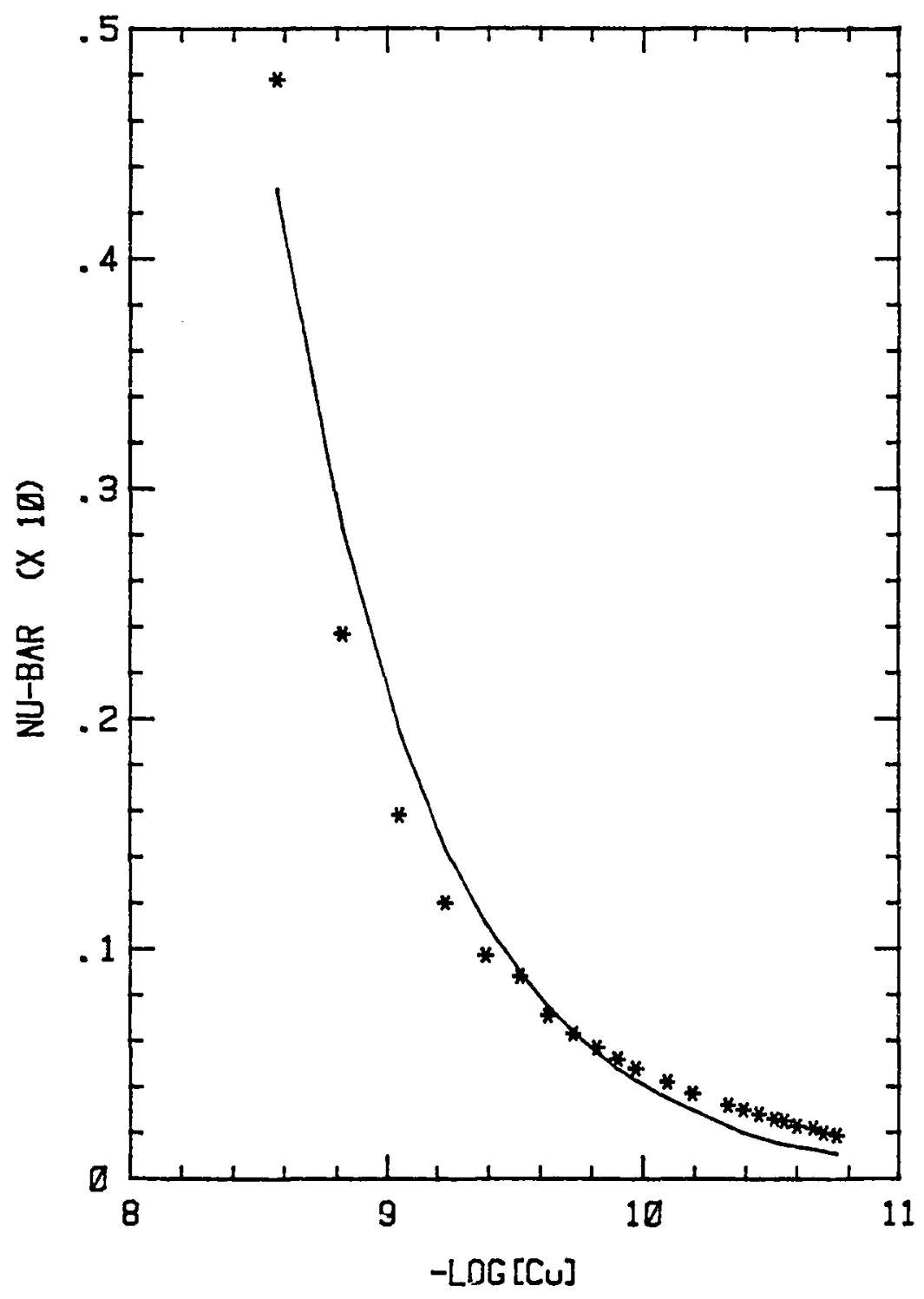

Figure 33. Experi mental data $(*)$ and calculated fit $(\longrightarrow)$ for the single mode Gaussian modeling of the pH 5.5 metal ion buffer titration 1 . Fitting parameters given in Table XIV. 


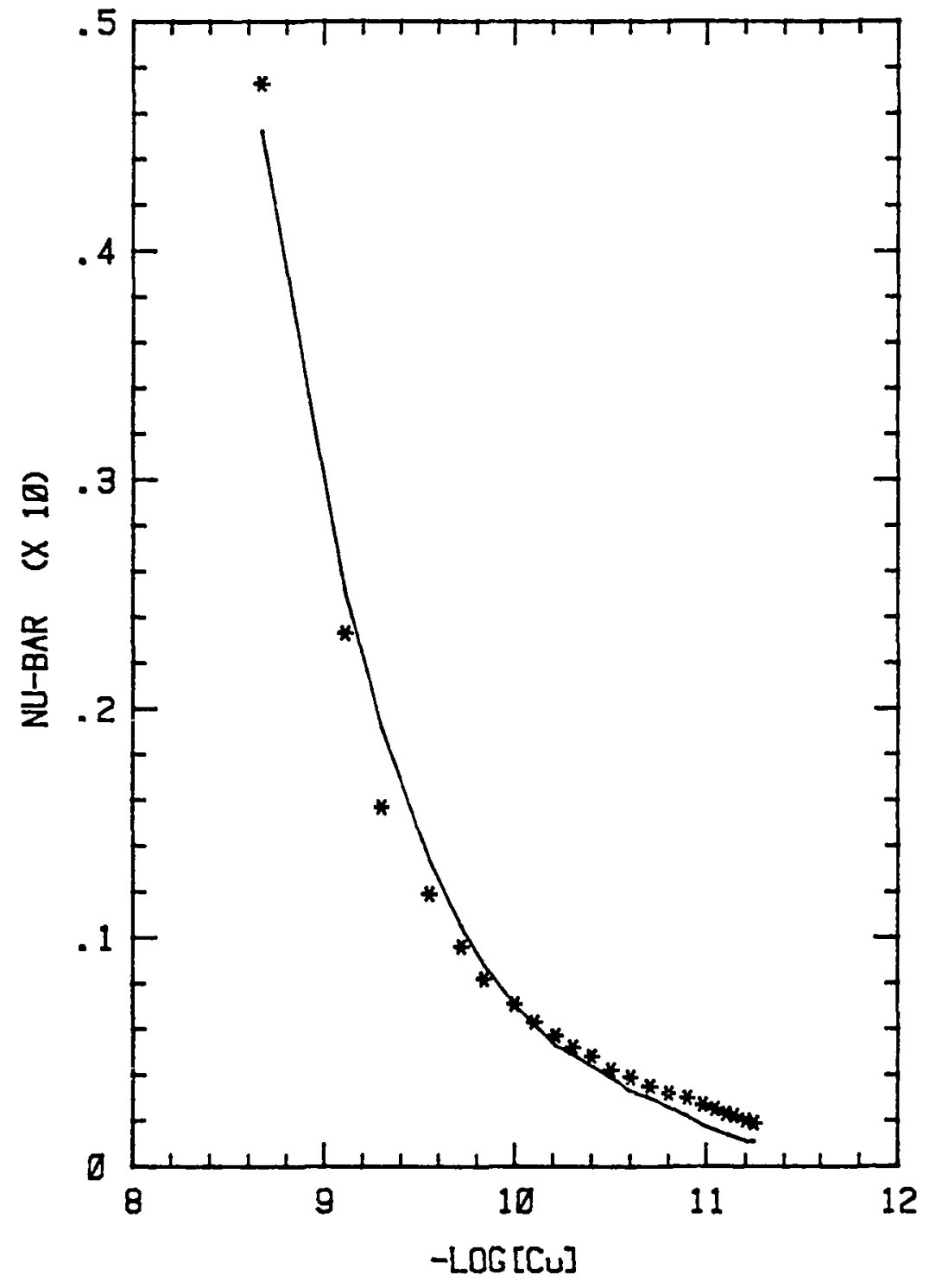

Figure 34. Experimental data $(*)$ and calculated fit $(\longrightarrow)$ for the single mode Gaussian modeling of the pH 6.0 metal ion buffer titration 非1. Fitting parameters given in Table XIV. 


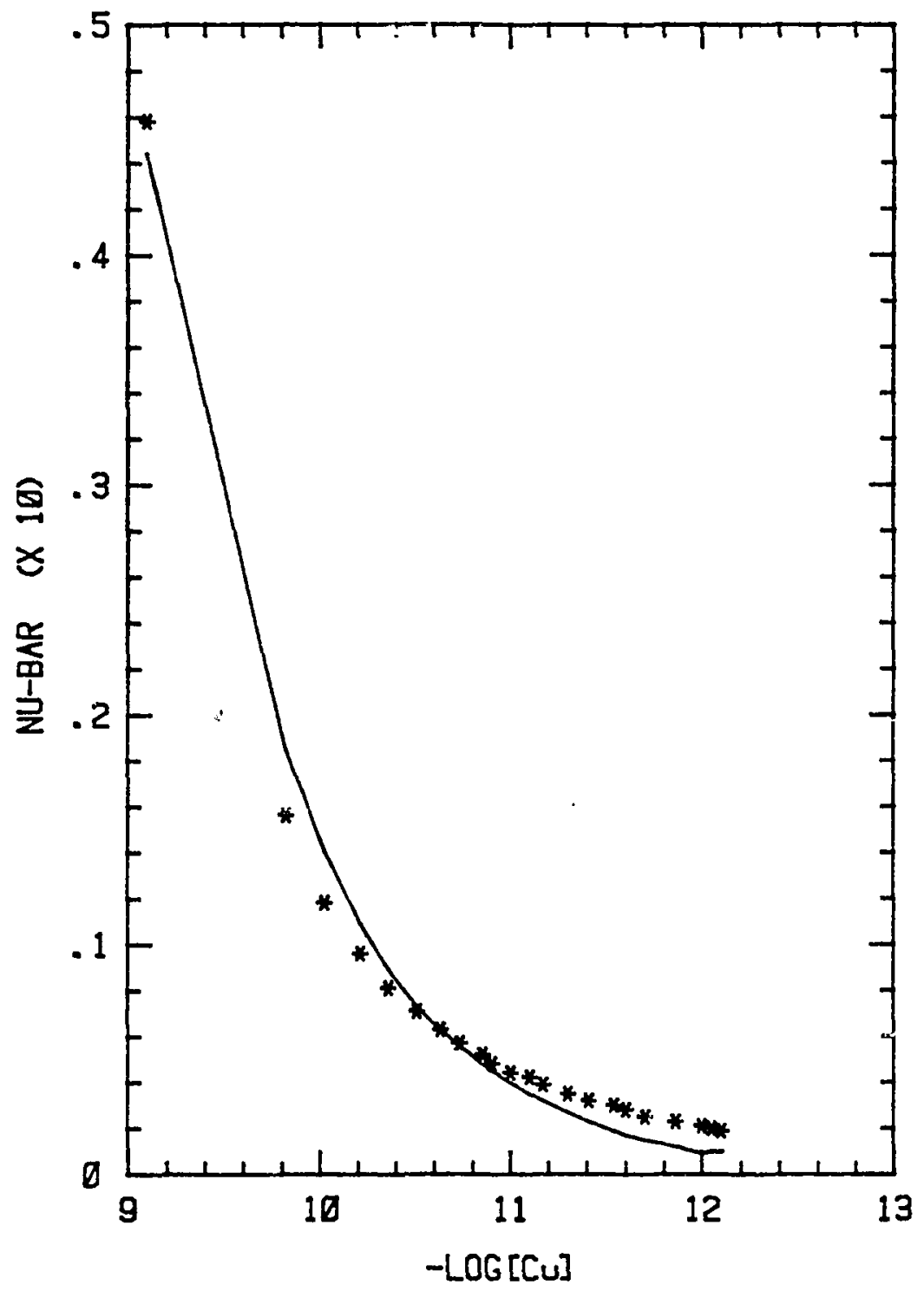

Figure 35. Experimental data (*) and calculated fit (-) for the single mode Gaussian modeling of the pH 6.5 metal ion buffer titration $2^{2}$. Fitting parameters given in Table XIV. 
the particular method must be employed or the data must be estimated from graphs. The calculated "raw" data can then be refitted to the Gaussian model. The underlying assumption is that the original fitting process used in the literature is accurate enough so as to be reversable. Many reports do not show calculated fits along with raw data, and some workers (cf Mantoura and Riley, 1975) use a Scatchard fitting method that does not use all of the raw data points. Another problem is that some literature reports fail to give the range of free metal ion concentrations found. Often, it can be estimated from graphs (Bresnahan et al., 1978) or inferred from $C_{M}, C_{L}$ data (McKnight et al., 1982). This is a very important point because the regeneration of the raw data can be done over any free metal concentration range desired. To accurately reflect the experimental conditions in a given literature report, the regenerated data should be calculated only for the free metal concentrations actually measured in that report. At low levels of free metal, $\bar{\tau}$ changes very rapidly. Any "extra" points added in this region by the regeneration will significantly alter the Gaussian parameters when the recalculated data is refit.

Given these problems and constraints, only three other literature reports contained enough information to allow a raw data regeneration of any rellability: two that used the Scatchard method (Bresnahan et al., 1978; Mcknight et al., 1982) and one that used a two-stoichiometry model (Bufflé et al., 1977). The original parameters and the Gaussian fitting parameters are compared in Table XV. Only aquatic humus samples were 
TABLE XV

COMPARISON OF FITTING PARAMETERS FROM THIS RESEARCH

AND FROM "CALCULATED" RAW DATA FROM THE LITERATURE

\begin{tabular}{|c|c|c|c|c|c|c|}
\hline Reference* & $\begin{array}{l}\text { Origi } \\
\text { ni }\end{array}$ & $\begin{array}{l}1 \text { Fitt } \\
\text { Log KI }\end{array}$ & $\begin{array}{l}\text { g Par } \\
\text { n2 }\end{array}$ & $\begin{array}{l}\text { ters } \\
\log K_{2}\end{array}$ & $\underset{\mu}{\text { Gaussian }}$ & $\underset{\sigma}{\text { Parameters }}$ \\
\hline A & - & -- & -- & -- & 4.00 & 1.62 \\
\hline B & -- & 4.8 & -- & 10.1 & 1.36 & 2.38 \\
\hline C & 0.23 & 6.11 & 0.77 & 3.85 & 4.27 & 0.81 \\
\hline D & 0.18 & 7.8 & 0.82 & 5.9 & 6.17 & 0.58 \\
\hline
\end{tabular}

* $A=$ this research; $B=$ Bufflé et al. (1977), sample III;

$C=$ Bresnahan et al. (1978), water sample; $D=$ McKnight et al. (1982), Suwannee River sample.

considered, and all the tabulated work was at $\mathrm{pH} 6.0$. To see if the widely varying discrete and Gaussian parameters could be due to modeling similar distributions over different portions of the distributions, the Gaussian parameters were used via Eq. 15 and 23 to calculate a global $\log \overline{\mathrm{K}}^{\prime}$ for a wide range of $C_{L} / C_{M}$ ratios. The results are shown in Fig. 36. Except for the fit for the recalculated data of Bresnahan et al., the values of the fitted $\log \overline{\mathrm{K}}^{\prime}$ are within about $0.4 \log$ units at the ligand:metal ratio of the world average river (indicated by the vertical arrow in Fig. 36). In light of the forementioned problems in generating raw data from literature reports, this similarity is striking 


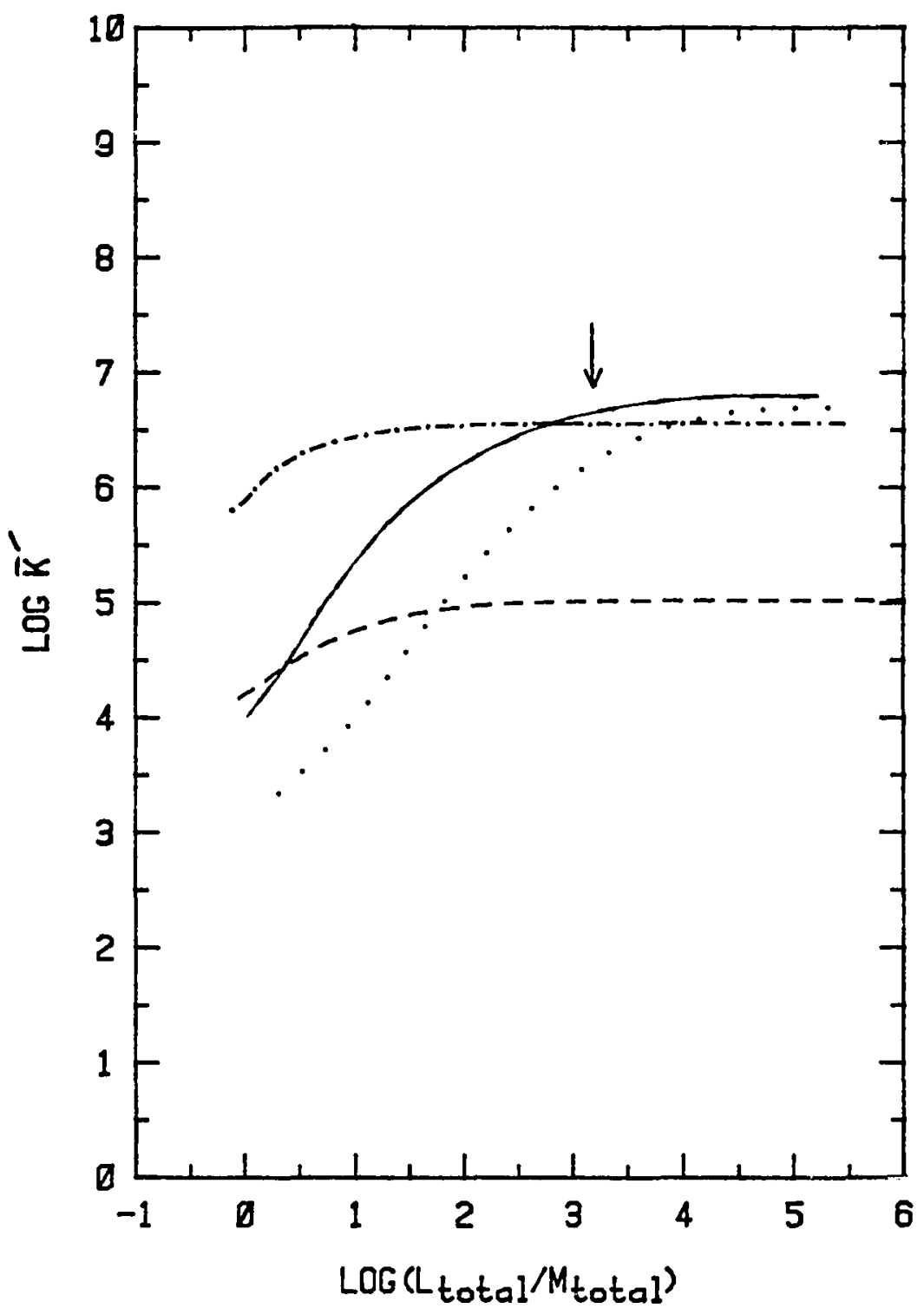

Figure 36. $\log \overline{\mathrm{K}}^{\prime}$ vs $\log C_{L} / C_{M}$ for Gaussian fits of data from this research and data calculated from the literature. $(\longrightarrow)=$ this research; $(\cdot \cdot \cdot)=$ Buffle et al. (1977); $(--\rightarrow)=$ Bresnahan et al. $\overline{(1978)} ;(-\cdot \rightarrow)=$ McKnight et a1. (1982). Arrow marks $\log \mathrm{C}_{\mathrm{L}} / \mathrm{C}_{\mathrm{M}}$ for the world average river. 
and suggests that the different humus samples used may have similar binding properties with copper. Thus it was felt that the widely varying resulis reported in the literature, as exemplified by the listing of original fitting parameters in Table XV, are not just functions of differences in humus but, more importantly, may also be functions of the range of total ligand and metal concentrations used in the experimental procedures.

This latter point may be the reason for the anomalous fit of the recalculated data of Bresnahan et al. shown in Fig. 36. It was stated earlier that the reason for conducting the copper, metal-ion buffer titrations was to duplicate the ligand:metal ratio found in the Williamson River. This necessitated lowering total copper to $10^{-7} \mathrm{M}$. The result was a close approximation to the absolute levels in the river. Figure 37 shows the experimental ranges of total copper in molar units and total ligand in $\mathrm{mg}$ humic carbon/liter for this research and nine other literature reports. Also shown is the value for the world average river (open circle) and the Williamson River at WR-50 (closed circle). It can be seen that only this research and the work of McKnight et al. match the levels for the world average river. Bresnahan et al. worked at a total copper concentration over three orders of magnitude greater. Thus, if the binding sites in aquatic humus in fact approach a continuum in their binding properties with copper, the work of Bresnahan et al. would represent the binding of copper to a much different portion of this distribution than that of Mcknight et al. or of this research. Also, it is admitted that the distribution of binding 


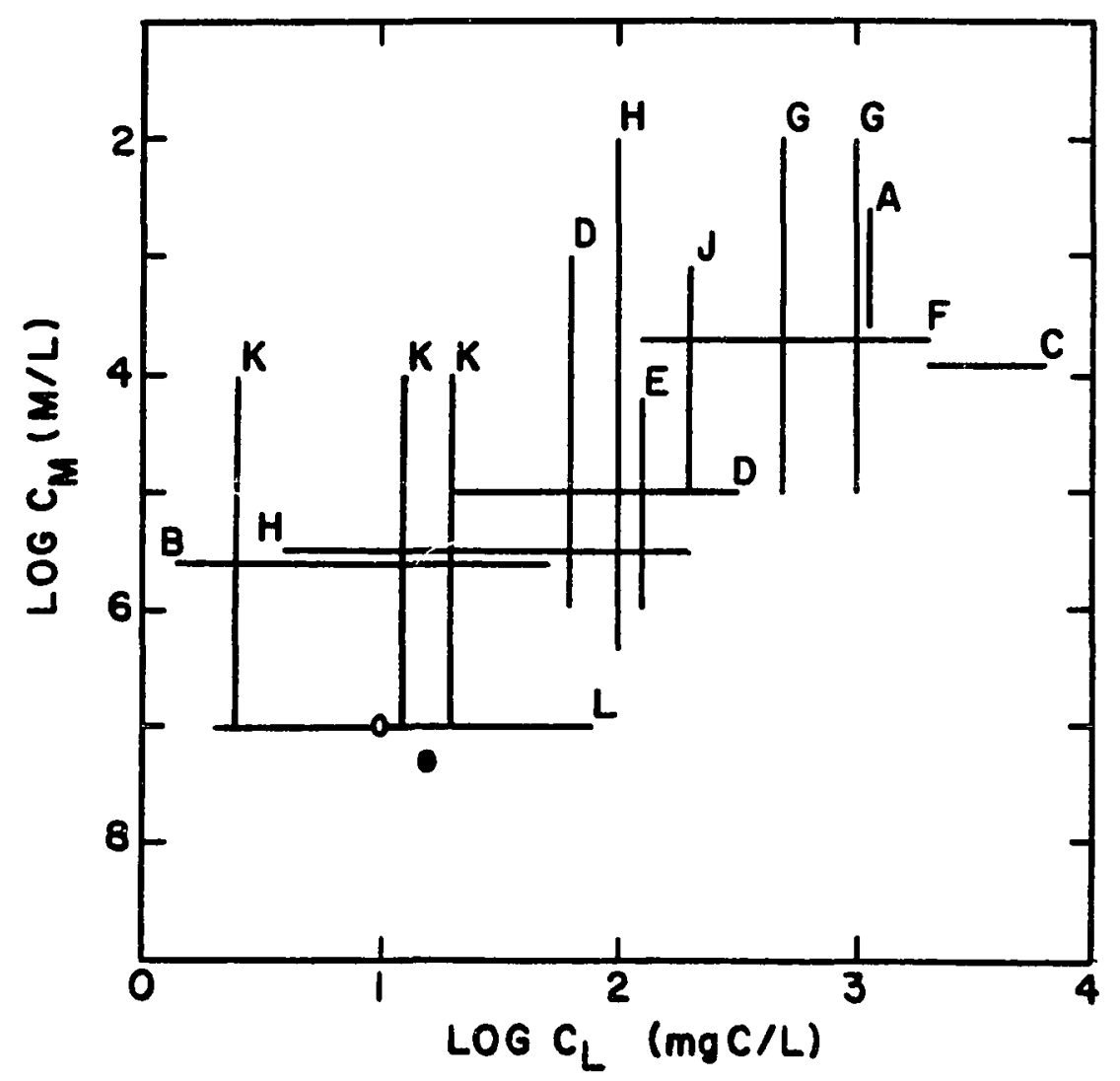

Fieve 37. Experimental conditions of total metal (moles/liter) and total ligand (in units of mg humic carbon/liter) for this research and for literature reports. $A=$ Stevenson et al. (1973); $B=$ Ernst et al. (1975); C = Mantoura and Riley (1975); $\bar{D}=$ Buffle et al. (1977); E Schuman and Woodward (1977); F = Bresnahan et al. $\overline{(1978)} ; G=$ Sposito et al. (1979); $H=$ Buffle et al. (1980); J = Gamble et al. (1980); $K=$ McKnight et al. (1982); $\mathrm{L}=$ this research. $(0)=$ world average river (Livingstone, 1963; Schlesinger and Melack, 1981). ( $(\bullet)=$ Williamson River at WR -50 . 
sites may not in fact be symmetrical and that the Gaussian model is only a first approximation. If the degree of asymetry is significant, the true shape of the distribution at environmental levels of ligand and metal may not be predictable at levels that are orders of magnitude greater. This is a strong possibility in a comparison of the results shown in Fig. 36 for the work of Bresnahan et al. and McKnight et al. because both originally fit their experimental data to the same model.

SUMMARY AND CONCLUSIONS

This research was undertaken to provide a clear understanding of the degree to which dissolved organic matter (DOM) complexes the test heavy metal, copper. While the particular results of this study pertain to DOM isolated from the Williamson River, Oregon (chosen for its high organic matter content), the methods, modeling techniques, and overall results are applicable to DOM in general.

Since DOM is primarily humic substances, carbohydrates, and proteinaceous matter, the first problem was to quantitate these fractions. Since the carbohydrate fraction had been studied by another worker, the proteinaceous fraction was studied in this research. Gas-liquid chromatography was used to examine hydrolyzable amino acids in the Williamson River and its main tributarles at monthly intervals over a two-year period. The relative abundances of amino acids showed little spactal or temporal changes, the order for the five most abundant being Gly > Asp > Ala $>$ Ser $>\cong$ Glu. Total amino acids varied greatly (two-year averages 
at twelve sampling sites ranged from about $0.5 \mu \mathrm{M}$ to about $8 \mu \mathrm{M}$ ) and correlated strongly with both discharge and humlc carbon. A separation technique utilizing a macoreticular resin showed that, for -hree t/pical sampling sites, $\geq 96 \%$ of the dissolved amino acids were associated with aquatic humus. Since it was found that amlno acids contributed less than $1 \%$ to humfe carbon and since another worker has shown that the carbohydrate portion of DOM contributes less than $2 \%$ to humic carbon, this research has provided the necessary data to make the conclusion that the study of copper complexation with DOM is essentially the study of copper complexation with humic substances.

For the examination of the binding of a metal to humus, it is most conventent if humus concentration can be expressed in units of moles/1iter. Because of ambiguity in the assigning of a molecular welght to the complex humic mixture, many researchers determine the complexation capacity of humus in terms of moles of metal capable of binding per unit welght of humus. This number, when multiplied by the welght concentration of humus, yields an operational humus concentration In units of moles metal capable of binding per 11ter. This research has shown that the accepted methods of expressing free metal versus total metal or total metal minus free metal versus total metal for a metalion-humus titration, underestimate this parameter. It has also been shown that these data plotting techniques yield complexation capacities that are dependent upon total 11gand concentration. However, it was shown that titrimetric data can be combined with acidic functional group analysis to arrive at a probable range for this parameter. For Willamson River humus, this range is $7.2-15.4 \mu \mathrm{mols}$ copper per mg humic 
carbon, and for subsequent work the average value of 11.3 was employed. Once this operational concentration unit was established for the aquatic humus, it was possible to address the problem of quantitating the extent of the copper-humus complexation reaction. Since most analytical techniques are incapable of measuring free metal ion at concentrations typical of natural waters, titration experiments are most often run at levels of metal and ligand concentration many times greater. To avold this artificiality as much as possible, humus was titrated into a copper-oxalate metal ion buffer. This allowed the measurement of free copper ion with an ISE to a concentration of $<10^{-11}$ M. The result was the ability to calculate the copper-humus binding constant at the same humus:copper ratio, the same absolute humus concentration, and at almost the same absolute copper concentration as that found in the Williamson River. It was found that the binding "constant" was in fact a variable over the almost two orders of magnitude of humus: copper ratio studied. This variable was also a function of $\mathrm{pH}$. At the average humus:copper ratio for the most humus-rich sampling site on the Williamson River, WR-50, the conditional stability "constants" at $\mathrm{pH} 5.0,5.5,6.0$, and 6.5 were: $3.0 \times 10^{6}, 8.9 \times 10^{6}, 3.0 \times 10^{7}$, and $1.7 \times 10^{8}$.

The functional nature of the metal-humus binding "constant" has been reported in the literature for copper and other heavy metals. The dilemma is that there is then no simple constant(s) that can be straightforwardly used to determine the extent of humus-metal binding in any general aquatic system. Researchers have solved this problem by modeling the binding as if humus possessed two or three discrete classes 
of binding sites or two or three discrete ligand stolchiometrles. Through the application of those models to computer-simulated titration data, this research has shown that these discrete models are Inadequate on two counts. First, the derived constants are only curve-fitting parameters and bear no relation to the actual constituants of multiligand mixtures. Second, the models are 1rcapable of modeling the functional nature of the binding "constant" from experimental levels of metal and ligand concentrations to levels that are environmentally significant. The conclusion of this portion of the research is that, because metal-humus titrations yield essentially featureless data plots, goodness-of-fit is not by liself sufficient to validate a model for metal-humus complexation. As an alternative it is proposed in this research that aquatic humus can be modeled as possessing a continuum of binding sites in which concentrations are normally distributed with respest to the sverage of the microscopic binding constants for each site. This model proved superior in its ability to follow the functional nature of the metal-humus binding "constant". It uses fewer fitting parameters and does not require knowledge of the actual values of the microscopic binding constants. Application of the model to proton binding data showed that the fitting parameters do reflect, both qualitatively and semiquantitatively, that known acid-base attributes of the humic mixture, 1.e. that its acid-base properties arlse primarily from a combination of carboxylic and phenolic function groups. Application of the model to copper binding data showed that it worked equally well for data collected at conventional levels of free metal concentrations and for data collected in the metal-ion buffer experiments at the extreme 
lower limit of free metal concentration. The conclusion of this final portion of the research is that the parameters derived from fitting metal-humus titration data to the proposed Gaussian distribution model can be readily used to supply the quantitative information necessary to Integrate the metal binding properties of aquatic humus into the overall matrix of trace metal transport in natural waters. 
REFERENCES

Alken, G. R., E. M. Thurman, R. L. Malcolm, and H. L. Walton (1979). Comparison of XAD macroporous resins for the concentration of fulvic acid from aqueous solution. Anal. Chem., 51: 1799-1803.

Alberts, J. J. and J. P. Giesy (1982). Conditional stability constants of trace metals and naturally occurring humic materials: Their appplication in equilibrium models and verification with fleld data. In Terrestrial and Aquatic Humic Materials. R. F. Christman and E. Gjessing (eds.) Ann Arbor, Michigan: Ann Arbor Press, In press.

Allen, H. E., M. L. Crosser, and T. D. Brisbin (1976). Metal speclation in aquatic environments. In Workshop on Toxiclty to Blota of Metal Forms in Natural Water. R. W. Andrew, P. V. Hodson, D. E. Konasewich (eds.) Duluth, Minnesota: U.S. Environmental Protection Agency, Environmental Research Laboratory.

Allen, H. E., R. H. Hall, and T. D. Brisbin (1980). Metal speciation. Effects on aquatic toxicity. Env. Sc1. Technol., 14: 441-443.

Allen, H. E., W. R. Matson, and K. H. Mancy (1970). Trace metal characterization in aquatic environments by anodic stripping voltammetry. J. Water Poll. Contr. Fed., 42: 573-581.

Andrew, R. W., K. E. Biesinger, and G. E. Glass (1977)-Effects of inorganic complexing on the toxicity of copper to Daphnia magna, Water Res., 11: 309-315.

Andrew, R. W., P. V. Hodson, and D. E. Konasewich (eds.) (1976). Toxicity to Biota of Metal Forms in Natural Waters. Duluth, Minnesota: U.S. Environmental Protection Agency, Environmental Research Laboratory.

Ardakant, M. S. and F. J. Stevenson (1972). A modifled lon-exchange technique for the determination of stability constants of metalso11 organic matter complexes. So11 Sc1. Soc. Amer. Proc., 36: 884-890. 
Baccinf, P. and U. Suter (1979). MELIMEX, an experimental heavy metal pollution study: Chemical speciation and biological availability of copper in lake water. Schweiz. Zeit. Hydro1., 41: 291-314.

Balistrier1, L. and J.W. Murray (1979). Surface of goethite in seawater. In Chemical Modeling in Aqueous Systems, E. A. Jenne (ed.) Washington, D.C.: American Chemical Society, Symposium Series 93.

Barber, R. T. and J. H. Ryther (1969). Organtc chelators: Factors affecting primary production in the Cromwell Current upwelling. J. Exp. Mar. Biol. Ecol., 3: 191-199.

Batley, G.E. and D. Gardner (1977). Sampling and storage of natural waters for trace metal analysis. Water Res., 11: 745-756.

Batley, G. E. and T. M. Florence (1976). A novel scheme for the classification of heavy metal species in natural waters. Anal. Letters, 9: 379-388.

Bayer, E., E. Grom, B. Kaltenegger, and R. Uhmann (1976). Separation of amino actds by high performance liquid chromatography. Anal. Chem., 48: 1106-1109.

Beck, K. C., J. H. Reuter, and E. M. Perdue (1974). Organic and inorganic geochemistry of some coastal plain rivers of the southeastern United States. Geochim. Cosmochim. Acta., 38: 341364 .

Benjamin, M. M. and J. 0. Leckie (1981). Competitive adsorption of $\mathrm{Cd}, \mathrm{Cu}, \mathrm{Zn}$, and $\mathrm{Pb}$ on amorphous iron oxjhydroxide. J. Colloid. Interface Sct., 83: 410-419.

Black, A. P. and R. F. Christman (1963a). Characteristics of colored surface waters. Am. Water Works Assoc. J., 55: 753-769.

Black, A. P. and R. F. Christman (1963b). Chemlcal characteristics of fulvic acids. Am. isater Works Assoc. J., 55: 879-912.

Blackburn, S. (1968). Amino Acld Determination. New York: Marcel Dekker.

Blaedel, W. J. and D. E. Dinwiddse (1974). Study of the behavior of copper ion selective electrodes at submicromolar concentration levels. Anal. Chem., 46: 873-877.

Blunk, D. (1982). Investigation of the contribution of aquatic humus to the transport of DDT in the environment. PhD Thesis. Portland State University, Portland Oregon.

Bowen, H. J. M., E. Page, I. Valente, and R. J. Wade (1979). Radiotracer methods for studying spectation in natural waters. $J_{\text {. }}$ 
Radioanal. Chem., 48: 9-16.

Boyle, E. A., J. M. Edmond, and E. R. Sholkovitz (1977). The mechanism of iron removal in estuaries. Geochim. Cosmochim. Acta, 41: 1313-1324.

Bresnahan, W. T., C. L. Grant, and J. H. Weber (1978). Stability constants for the complexation of copper (II) lons with water and soll fulvic acids measured by an ion selective electrode. Anal. Chem., 50: 1675-1679.

Buffle, J. and A. Cominoli (1981). Voltammetric study of humic and fulvic substances. Part IV. Behavior of fulvic substances at the mercury-water interface. J. Electroanal. Chem., 121: 273-299.

Buffle, J., P. Deladoey, F.-L. Greter, and W. Haerdi (1980). Study of the complex formation of copper (II) by humic and fulvic substances. Anal. Chim. Acta., 116: 255-274.

Burch, D. R., C. H. Langford, and D. S. Gamble (1978). Methods for the comparison of fulvic acid samples: the effects of origin and concentration on acidic properties. Can. J. Chem., 56: 1196-1201.

Burleson, J. L., G. R. Peyton, and W. H. Glaze (1980). Gas-chromatographic/mass-spectrometric analysis of derivatized amino acids In muncipal waste water products. Env. Sci. Technol., 14: 1354-i359.

Campbell, P. E... C., M. Bisson, R. Gagne, and A. Tessier (1977). A critical evaluation of the copper (II) solubilization method for the determination of the complexation capacity of natural waters. Anal. Chem., 49: 2358-2363.

Carter, P. W. and R. M. Mitterer (1978). Amino acid composition of organic matter associated with carbonate and non-carbonate sediments. Geochim. Cosmochim. Acta., 42: 1231-1238.

Chau, Y. K., R. Gachter, and K. Lum-Shue-Chan (1973). Determination of the apparent complexing capacity of Lake Waters. J. Fish. Res. Board Can., 31: 1515-1519.

Cheam, V. (1973). Chelation study of the copper (II): fulvic acid system. Can. J. Soll Sc1., 53: 377-382.

Cheam, V. and D. S. Gamble (1974). Metal-fulvic acid chelation equilibrium in aqueous $\mathrm{NaNO}_{3}$ solution. $\mathrm{Hg}(\mathrm{II}), \mathrm{Cd}$ (II), $\mathrm{Cu}$ (II) fulvate complexes. Can. J.- Soil Sci., 54: 413-417.

Christman, R. F. (1970). Chemlcal structures of color producing organic substances in water. In Organic Matter in Natural Waters, D. W. Hood (ed.) College, Alaska: Institute of Marine Science, 
Occasional Publication No. 1.

Christman, R. F. and M. Ghassemi (1966). Chemical nature of organic color in water. Am. Water Works Assoc. J., 58: 723-741.

Christman, R. F. and R. A. Minear (1971). urganics in lakes. In Organic Compounds in Aquatic Environments, S. J. Faust and J. V. Hunter (eds.) New York: Marcel Derker.

Crosser, M. L. and H. E. Allen (1977). Determination of the complexation capactty of soluble ligands by fon exchange equilibrium. So11 Sc1., 123: 176-181.

Crosser, M. L. and H. E. Allen (1978). Complexation of heavy metals by ligands in industrial waste water - measurement and effect on metals removal. In Proceedings of the 32nd Industrial Water Conference. Ann Arbor: Ann Arbor Sclence.

Dahm, C. N. (1980). Oregon State University, personal communication.

Davey, E. W., M. J. Morgan, and S. J. Erickson (1973). A biological measurement of copper complexation capacity of seawater. Limnol. Oceanogr., 18: 993-997.

Davis, J. A. and J. 0. Leckle (1979). Speciation of adsorbed lons at the oxide/water interface. In Chemical Modeling in Aqueous Systems, E. A. Jenne (ed.). Washington, D.C.: American Chemical Society, Symposium Series 93.

Erickson, S. J., T. E. Maloney, and J. H. Gentile (1970). Effect of nitrilotriacetic acid on the growth and metabolism of estuarine phytoplankton. J. Water Pollution Cont. Fed., 42: 329-335.

Ernst, R., H. E. Allen, and K. H. Mancy (1975). Characterization of trace metal species and measurement of trace metal stability constants by electrochemical means. Water Res., 9: 969-979.

Felker, P. and R, S. Bandurski (1975). Quantitative gas-1iquid chromatography and mass spectroscopy of the $N(0)$-perfluorobutyry1o-1soamyl derivatives of amino ac1ds. Anal. Blochem., 67: 245262 .

Florence, T. M. (1977). Trace metal species in fresh waters. Water Res., 11: 681-687.

Gachter, R., K. Lum-Shue-Chan, and Y. K. Chau (1973). Complexing capacity of the nutrient medium and 1 ts relation to inhibition of algal photosynthesis by copper. Schwelz. Zeit. Hydrol., 35: 252-260.

Gahler, A. R. (1969). Field studies on sediment-water algal nutrient 
Interchange processes and water quality of Upper Klamath and Agency Lakes. Corvallis, Oregon: Paciflc Northwest Water Laboratory, Working Paper No. 66.

Gamble, D. S. (1972). Potentlometric titration of fulvic acid: equivalence point calculations and acidic functional groups. Can. J. Chem., 50: 2680-2690.

Gamble, D. S. (1973). Sodium and potassium binding by fulvic acid. Can. J. Chem., 51: 3217-3222.

Gamble, D. S., M. Schnttzer, and I. Hoffman (1970). Copper(II) fulvic actd chelation equilibrium in $0.1 \mathrm{M} \mathrm{KCl}$ at $25.00 \mathrm{C}$. Can: Is Chem: 48: 3197-3204.

Gamble, D. S., A. W. Underdown, and C. H. Langford (1980). Copper(II) titration of fulvic acid ligand sites with theoretical, potentiometric, and spectrophotometric analysis. Anal. Chem., 52: 1901-1908.

Gardiner, J. (1974). The chemistry of cadmium in natural water - I. A study of cadmium complex formation using the cadmium ion selective electrode. Water Res., 8: 23-30.

Gardner, W. S. and G. F. Lee (1973). Gas chromatographic procedure to analyze amino acids in lake waters. Env. Sci. Technol., 7: 719724.

Garrels, R. M. and F. T. Mackenzie (1971). Evolution of Sedimentary Rocks. New York: W. W. Norton P. 105.

Giesy, J. R., L. A. Briese, and G. J. Leversee (1978). Metal binding capacity of selected Maine surface waters. Env. Geol., 2: 257268.

Greter, F.-L., J. Buffle, and W. Haerd1 (1979). Voltametric study of humic and fulvic substances. Part I. Study of the factors influencing the measurement of their complexing properties with lead. J. Electroanal. Chem., 101: 211-229.

Guy, R. D. and C. L. Chakrabarti (1976). Studies of metal-organic inceractions in model systems pertaining to natural waters. Can. J. Chem., 54: 2600-2611.

Guy, R. D., C. L. Chakrabart1, and L. K. Schramm (1975). The application of a simple chemical model of natural waters to metal fixation in particulate matter. Can. J. Chem., 53: 661-669.

Hanck, K. W. and J. W. Dillard (1973). Determination of the complexing capacity of natural water. University of North Carolina Water Resources Research Institute, Pub. No. UNC-WRRI-73-85. 
Hedges, J. (1982). University of Washington, personal communication.

Hirata, S. (1981). Stability constants for the complexes of transitionmetal lons with fulvic and humlc acids in sediments measured by gel filtration. Talanta, 28: 809-815.

Hood, D. W. (ed.) (1970). Organic Matter in Natural Waters. College, Alaska: Institute of Marine Sclence. Occasional Publication No. 1 .

Hullett, D. A. and S. J. Elsenreich (1979). Determiantion of free and bound fatty aclds in river water by high performance liquid chromatography. Anal. Chem., 51: 1953-1960.

Husek, P. and K. Macek (1975). Gas chromatography of amino acids. J. Chrom., 113: 139-23u.

Hutchinson, G. E. (1957). A Treatise on Limnology. I. Geography, Physics, and Chemistry. New York: Wiley.

Iliaifar, S. (1982). Portland State University, personal communication.

Johnston, R. (1964). Sea water, the natural medium of phytoplankton. II. Trace metals and chelation and general discussion. J. Mar. Biol. Assoc. U.K., 44: 87-110.

Kaiser, K. L. E. (1980). Correlation and prediction of metal toxicity to aquatic biota. Can. J. F1sh. Ag. Sc1., 37: 211-218.

Kaiser, F. E., C. W. Gehrke, R. W. Zumwalt, and K. C. Kuo (1974). Amino acid analysis. Hydrolysis, ion-exchange cleanup, derivatization, and quantitation by gas-liquid chromatography. J. Chrom., 94: 113-133.

Karush, F. and M. Sonenberg (1949). Interaction of homologous alkyl sulfates with bovine serum albumin. J. Am. Chem. Soc., 71: 1369-1376.

Kennish, J. (1979). University of Alaska, personal communication.

Kol thoff, I. M., E. B. Sandell, E. J. Meehan, and S. Bruckenstein (1969). Quantitative Ohemical Analysis, 4th Ed. New York: MacMillan.

Kunkel, R. and S. E. Manahan (1973). Atomic absorption analysis of strong heavy metal chelating agents in water and wastewater. Anal. Chem., 45: 1465-1468.

Laltinen, H. A. and Harris (1975). Chemical Analysis, 2nd Edition. New York: McGraw-Hi11. 
Lamar, W. L. (1968). Evaluation of organic color and iron in natural surface waters. U. S. Geol. Survey Prof. Paper, 600-D: D-24 D-29.

Langford, C. H., T. R. Khan, and G. B. Skippen (1979). On the nature of the complexing capacity of natural waters: Functional group based fractionation of a sample from the Indian River, Ontario. Inorg. Nucl. Chem. Letters, 15: 291-295.

Laxen, D. P. H. and R. M. Harrison (1981). Cleaning methods for polythene containers prior to the determination of trace metals In freshwater samples. Anal. Chem., 53: 345-350.

Lee, C. and J. L. Bada (1977). Dissolved amino acids in the Equatorial Pacific, the Sargasso Sea and Biscayne Bay. Limnol. Oceanogr., 22: $502-510$.

Leenheer, J. A. (1980). Origin and nature of humic substances in the waters of the Amazon River basin. Acta Amazonica., 10: 513-526.

Leenheer, J. A. and E. W. D. Huffman (1976). Classification of organic solutes in water by using macroreticular resins. J. Res. U. S. Geol. Survey, 4: 737-751.

Leenheer, J. A. and C. L. Dunham (1973). Preparing high efficlency packed GC columns. Res./Dev., 24: 32-38.

Leonard, A. R. and A. B. Harris (1974). Ground water in selected areas In the Klamath Basin, Oregon. United States Geological Ground Water Report No. 21 .

Lindroth, P. and K. Mopper (1979), HPLC determination of subpicomole amounts of amino acids by precolumn fluorescence derivatization with o-phthaldialdehyde. Anal. Chem., 51: 1667-1674.

Livingstone, D. A. (1963). Chemical composition of rivers and lakes. In Data of Geochemistry, 6th Ed. M. Fleisher (ed.) U. S. Geological Survey, paper $\overline{440}-\bar{G}$.

MacCarthy, P. (1974). Fulvic Acid: I. Partial Fractionation. J. So11 Sci., 25: 420-428.

MacCarthy, P. (1977a). Some comments on the derivation of Schubert's ion-exchange equations. So11 Sc1., 123: 207.

MacCarthy, P. (1977b). An interpretation of stability constants for soll organic matter-metal ion complexes under Schubert's conditions. J. Environ. Sci. Health, Al2: 43-59.

MacCarthy, P. and H. B. Mark (1977). A further examination of the Schubert 1on-exchange method as applied to soll organic matter- 
metal Interactions. In Biological Implication of Metals in the Environment. H. Drucker and R. E. Wildung (eds.). Springfield, Virginia: National Technical Information Service, ERDA Conference 750929 .

MacCarthy, P. and G. C. Smith (1979). Stability surface concept: A quantitative model for complexation in multiligand mixtures. In Chemical Modeling in Aqueous Systems. T. A. Jenne (ed.). Washington, D. C.: American Chemical Society, Symposium Series 93.

Macko, S. A. and E. J. Green (1979). The quantification of amino acids in seawater using thin-layer chromatography and fluorimetry, Marine Chem., 8: 181-189.

Magnuson, V. R., D. K. Harriss, M. S. Sun, D. K. Taylor, and G. E. Glass (1979). Relationships of activitles of metal-ligand species to aquatic toxicity, in Chemical Modeling in Aqueous Systems, E. A. Jenne (ed.). Washington, D.C.: American Chemical Society, Symposium Series 93.

Mantoura, R. F. C., A. Dickson, and J. P. Riley (1978). The complexation of metals with humic materials in natural waters. Estuar. Coastal Marine Sci., 6: 387-408.

Mantoura, R. F. C. and J. P. Riley (1975). The use of gel filtration in the study of metal binding by humic acids and related compounds. Anal. Chim. Acta., 78: 193-200.

Mart, L. (1979). Prevention of contamination and other accuracy risks in voltammetric trace metal analysis of natural waters, I: Preparatory steps, filtration, and storage of water samples. Anal. Chemie, 296: 350-357.

Matson, W. R. (1968). Trace metals, equilibrium, and kinetics of trace metal complexes in natural media. PhD Thesis, Massachusetts Institute of Technology, Cambridge, Massachusetts.

McDuffie, B., I. El-Barbary, G. L. Hollod, and R. D. Tiberio (1976). Trace metals in rivers-speciation, transport, and role of sediments. In Trace Substances in Environmental Health, D. D. Hemph111 (ed.). Columbia, Missouri: Univ. Missouri Press.

McKnight, D. M., G. L. Feder, E. M. Thurman, R. L. Wershaw, and J. C. Westall (1982). Complexation of Copper by Aquatic Humic Substances from Different Environments. J. Sci. Total Env. (in press).

Miller, W. E. and J. G. Tash (1967). Interim Report: Upper Kalamath Lake Studies, Oregon. Corvallis, Oregon: Pacific Northwest Water Laboratory, Publication WP-20-8.

Nordstrom, D. K., L. N. Plummer, T. M. L. Wigley, T. J. Wolery, J. W. 
Ball, E. A. Jenne, R. L. Bassett, D. A. Crerar, T. M. Florence, B. Fritz, M. Hoffman, G. R. Holdren, Jr., G. M. Lafon, S. V. Mattigod, R. E. McDuff, F. Morel, M. M. Reddy, G. Sposito, J. Thrallkill (1979). A comparison of computerized chemical models for equilibrium calculations in aqueous systems. In Chemlcal Modeling in Aqueous Systems, E. A. Jenne (ed.). Washington, D.C.: American Chemical Society, Symposium Series 93.

Norris, A. C. (1981). Computational Chemistry. New York: John Wiley and Sons.

O'Shea, T. A. and K. H. Mancy (1976). Characterization of trace metalorganic Interactions by anodic stripping voltametry. Ânal. Chem., 48: 1603-1607.

Pagenkopf, G. K. and D. Cameron (1979). Deposition of trace metals In stream sediments. Water, Air, Soll Poll., 11: 429-435.

Pagenkopf, G. K., R. C. Russo, and R. V. Thurston (1974). Effect of complexation on toxicity of copper to fishes. J. Fish. Res. B. Can., 31: 462-465.

Parrish, R. (1982). U. S. Environmental Protection Agency, Environmental Research Laboratory, Athens, Georgia, personal communication.

Peake, E., B. L. Baker, and G. W. Hodgson (1972). Hydrogeochemistry of the surface waters of the Mackenze River drainage basin, Canada. II. The contribucion of amino acids, hydrocarbons, and chlorins to the Beaufort Sea by the Mackenzie River system. Geochim. Cosmochim. Acta., 36: 867-883.

Perdue, E. M. (1979). Solution thermochemistry of humic substances. In Chemical Modeling in Aqueous Systems. E. A. Jenne (ed). Washington, D. C.: American Chemical Society, Symposium Series 93.

Perdue, E. M. (1982). Portland State University, personal communication.

Perdue, E. M., C. R. Lytle, M. S. Sweet, and J. Sweer (1981). The chemical and biological impact of Klamath Marsh on the Williamson River, Oregon. Corvallis, Oregon: Oregon State University Water Resources Research Institute, Publication No. WRRI -71 .

Perdue, E. M., J. H. Reuter, and M. Ghosal (1980). The operational nature of acidic functional group analyses and its impact on mathematical descriptions of acid-base equilibria in humic substances. Geochim. Cosmochim. Acta, 44: 1841-1851. 
Peterson, N. V. and J. R. McIntrye (1970). The reconnalssance geology and mineral resources of Eastern Klamath County and Western Lake County, Oregon. Portland, Oregon: State of Oregon Department of Geology and Mineral Resources.

Pocklington, R. (1972). Determination of nanomolar quantitles of free amino acids dissolved in North Atlantic Ocean waters. Anal. Blochem., 45: 403-421.

Posner, A. M. (1964). Titration curves of humic acid. In Procedings of the 8th International Congress of Soll Science, Part II. Bucharest, Romania.

Posner, A. M. (1966). The humic acids extracted by varfous reagents from a soll. Part I. Yield, Inorganic components, and titration curves. J. So11 Sc1., 17: 65-78.

Ramamoorthy, S. and D. K. Kushner (1975). Heavy metal binding components of river water. J. Fish. Res. Board Can., 32: 17551766 .

Reuter, J. H. and E. M. Perdue (1977). Importance of heavy metalorganic matter interactions in natural waters. Geochim. Cosmochim. Acta., 41: 325-334.

Roe, D. K. Portland State University, personal comunication.

Rohm and Haas (1971). Sumary Bulletin. Amberlite Polymeric Absorbants. Philadeiphla: kohm and haas Company。

Ryan, D. K. and J. H. Weber (1982). A fluorescence quenching titration technique for determiantion of complexing capacities and stability constants of fulvic acid.

Saar, R. A. and J. H. Weber (1979). Complexation of cadmium (II) with water- and soll-derived fulvic acid: Effect of $\mathrm{pH}$ and fulvic acid concentration. Can. J. Chem., 57: 1263-1268.

Saar, R. A. and J. H. Weber (1980). Lead (II) complexation by fulvic acid: How it differs from fulvic acid complexation of copper (II) and cadmium (II). Geochim. Cosmochim. Acta., 44: 1381-1384.

Scatchard, G. (1949). The attractions of proteins for small molecules and 1ons. Ann. N. Y. Acad. Sc1., 51: 660-672.

Scatchard, G., J. S. Coleman, and A L. Shen (1957). Physical chemistry of protein solutions. VII. The binding of some small anions to serum albumin. J. Am. Chem. Soc., 79: 12-20.

Schlesinger, W. H. and J. M Melack (1981). Transport of organic carbon in the world's rivers. Tellus, 33: 172-187. 
Schnitzer, M. and S. U. Khan (1972). Humic Substances in the Environment. New York: Marcel Dekker.

Schubert, J. (1948). The use of lon exchangers for the determination of physical-chemical properties of substances, particularly radiotracers in solution: I. Theorectical. J. Phys. Coll. Chem, 52: $340-350$.

Semenov, A. D., A. P. Pashanova, T. S. KIshkinova, and L. I. Nemtseva (1967). Content of individual groups of organic substances in the waters of some Soviet rivers. Soviet Hydrology: Selected Papers, 5: 549-553.

Shapiro, J. (1957). Chemical and blological studies on the yellow organic acids of lake water. Ilmnol. Oceanogr., 2: 161-169.

Shaw, T. L. and V. M. Brown (1974). The toxicity of some forms of copper to rainbow trout. Water Res., 8: 377-382.

Shuman, M. S. and G. P. Woodward (1977). Stability constants of copperorganic chelates in aquatic samples. Env. Sc1. Technol., 11: 809-813.

Sillen, L. G. and A. E. Martell (1964). Stability Constants of Metal-ion Complexes. London: The Chemical society, Special Publication No. 17.

S1ps, R. (1948). On the structure of a catalyst surface. J. Chem. Physics, 16: 490-495.

Skoog, D. A. and D. M. West (1963). Fundamentals of Analytical Chemistry. New York: Holt, Rinehart, and Winston.

Smith, R. G. (1976). Evaluation of comblned applications of ultrafiltration and complexation capacity techniques to natural water. Anal. Chem., 48: 74-76.

Sohn, M. L. and M. C. Hughes (1981). Metal Ion complex formation constants of some sedimentary humic acids with $\mathrm{Zn}$, (II), $\mathrm{Cu}$ (IT), and Cd(II). Geochim. Cosmochim. Acta, 45: 2393-2399.

Spackman, D. H., W. H. Stein, and S. Moore (1958). Automatic recording apparatus for use in the chromatography of amino acids. Anal. Chem., 30: 1190-1206.

Spencer, C. P. (1957). Ultilization of trace elements by marine unicellular algae. J. Gen. Microblol., 16: 282-285.

Sposito, G. (1981). Trace metals in contaminated waters. Env. Sc1. Technol., 15: 396-403. 
Sposito, G. and K. M. Holtzclaw (1979). Copper (II) complexation by fulvic actd extracted from sewage sludge as influenced by nitrate versus perchlorate background lonlc media. Soll Sc1. Soc. Am. J., 43: 47-51.

Sposito, G., K. M. Holtzclaw, and C. S. Levesque-Hadore (1978). Calcium ion couplexation by fulvic acid extracted from sewage sludge-so11 mixtures. So11 Sc1. Soc. Am. J., 42: 600-606.

Sposito, K. M. Holtzclaw, and C. S. Levesque-Madore (1979). Cupric Ion complexation by fulvic acid extracted from sewage sludge-soll mixtures. So11 Sc1. Soc. Am. J., 43: 1148-1155.

Steemann-Nielsen, E. and S. Wium-Anderson (1970). Copper lons as poison in the sea and in fresh water. Mar. Biol., 6: 93-97.

Stella, R. and M. T. Ganzerli-Valentini (1979). Copper Ion selective electrode for the determination of Inorganic copper species in fresh waters. Anal. Chem., 51: 2148-2151.

Stevenson, F. J. (1976). Stability constants of copper(II), lead(II), and cadmium(II) complexes with humlc acids. Soil Sc1. Soc. Am. J., 40: 665-672.

Stevenson, F. J. and J. H. A. Butler (1969). Chemistry of humic acids and related pigments. In Organic Geochemistry, G. Eglinton and M. T. J. Murphy (eds.). New York: Springer Verlag.

Stevenson, F. J., S. A. Krastanov, and M. S. Ardakani (1973). Formation constants of copper (II) complexes with humic and fulvic acids. Geoderma, 9: 129-141.

Stiff, M. J. (1971). Copper-bicarbonate equilibria in solutions of bicarbonate ion at concentrations similar to those found in natural water. Water Res., 5: 171-176.

Stuermer, D. H. and G. R. Harvey (1978). The isolation of humic substances and alcohol-soluble organic matter from sea water. Marine Chem., 6: 55-70.

Stumm, W. and H. Bilinsk1 (1977). Trace metals in nature? waters; difficuities of interpretation arising from our ignorance on their speciation. In Advances in Water Pollution Research, Sixth International Conference Procedings, Jerusalem, S. H. Jenkins (ed.). New York: Pergamon Press.

Stumm, W. and J. J. Morgan (1970). Aquatic Chem1stry. New York: Willey-Interscience, p. 490 .

Sturgeon, R. E., S. S. Berman, A. Desaulniers, and D. S. Russell (1980). Preconcentration of trace metals from seawater for determination 
by graphite furnace atomic absorption spectrometry. Talanta, 27: $85-94$.

Subramanian, K. S., C. L. Chakrabari, J. E. Sueiras, and I. S. Maines (1978). Preservation of some trace metals in samples of natural waters. Anal. Chem., 50: 444-448.

Sunda, W., D. W. Engel, and R. M. Thuotte (1978). Effect of chemical speciation on the toxiclty of cadmium to grass shrimp: Importance of free cadmium Ion. Env. Sc1. Technol., 12: 409-413.

Sunda, W. and R. R. L. Guillard (1976). The relation between copper ion activity and the toxicity of copper phytoplankton. J. Marine Res., 34: 511-529.

Sunda, W. G. and J. M. Lewis (19?8). Effect of complexation by natural organic ligands on the toxictty of copper to a unfcellular alga. Monochrysis 1utheri, Limnol. Oceanogr, 23: 870-876.

Sweet, M. S. (1979). The concentration and speciation of sugars in natural waters. Master's Thes1s, Portland State University, Portland, Oregon.

Tajlma, M. (1978). Comparative study between gas-1iquid chromatography and ion exchange chromatography on amino actd analysis of foods. Agr1. Biol. Chem., 42: 1949-1953 (1978).

Tessler, A., P. G. C. Campbell, and M. Bisson (1979). Sequential extraction procedure for the speciation of particulate trace metals. Anal. Chem., 51: 844-850.

Truitt, R. E. and J. H. Weber (1981). Determination of complexing capacity of fulvic acid for copper (II) and cadmium (II) by dialysis titration. Anal. Chem., 53: 337-342.

Van den Berg, C. M. G. and J. R. Kramer (1979). Determination of complexing capacities of ligands in natural waters and conditional stability constants of the copper complexes by means of manganese dioxide. Anal. Chim. Acta, 106: 113-120.

Voge1, A. I. (1974). A Textbook of Practical Organic Chemistry. London: Longman Group Limited.

Vucenta, J. and J. J. Morgan (1978). Chemical modeling of trace metals In fresh waters: role of complexation and adsorption. Env. Sci. Technol., 12: 1302-1309.

Weber, J. H. and K. H. Cheng (1979). Nonadsorption of fulvic acid from aqueous solutions on glassy carbon or wax sealed graphte electrodes. Anal. Chem., 51: 796-799. 
Weber, J. H. and S. A. Wilson (1975). The isolation and characterIzation of fulvic acid and humic acid from river waters. Water Res., 9: 1079-1084.

Westall, J. and H. Hohl (1980). A comparison of electrostatic models for the oxide/solution interface. Adv. Coll. Interface Sc1., 12: $265-294$.

Westall, J. C., J. L. Zachary, and F. M. M. Morel (1976). MINEQL, a computer program for the calculation of chemlcal equilibrium composition of aqueous systems. Cambridge, Massachusetts: Mass. Inst. Technol., Technical Note. No. 18.

Wetzel, R. G. (1975). Limnology. Philadelphia: W. B. Saunders, p. 540.

Wilson, A. L. (1959). Determination of fulvic acids in water. J. Appl. Chem., 9: 501-512.

Zanetta, J. P. and G. Vincendon (1973). Gas-liquid chromatography of the $N(0)$ - Heptafluorobutyrates of the isoamyl esters of amino acids. I. Separation and quantitative determination of the constituent amino acids of proteins. J. Chrom., 76: 91-99.

Zumwalt, R., K. Kuo, and C. W. Gehrke (1971). Nanogram and picogram method for amino acid analysis in gas-liquid chromatography. J. Chrom., 57: 193-208. 


\section{APPENDIX A: HATIT PROGRAM LISTING}

This program, written in Basic for the Rockwell Aim 65 microprocessor, was designed to automatically run titrations. The program is in four main parts: data input, standardization, running the titration and data collection, and calculations and printout. Standardization is accomplished by least squares linear regression. 


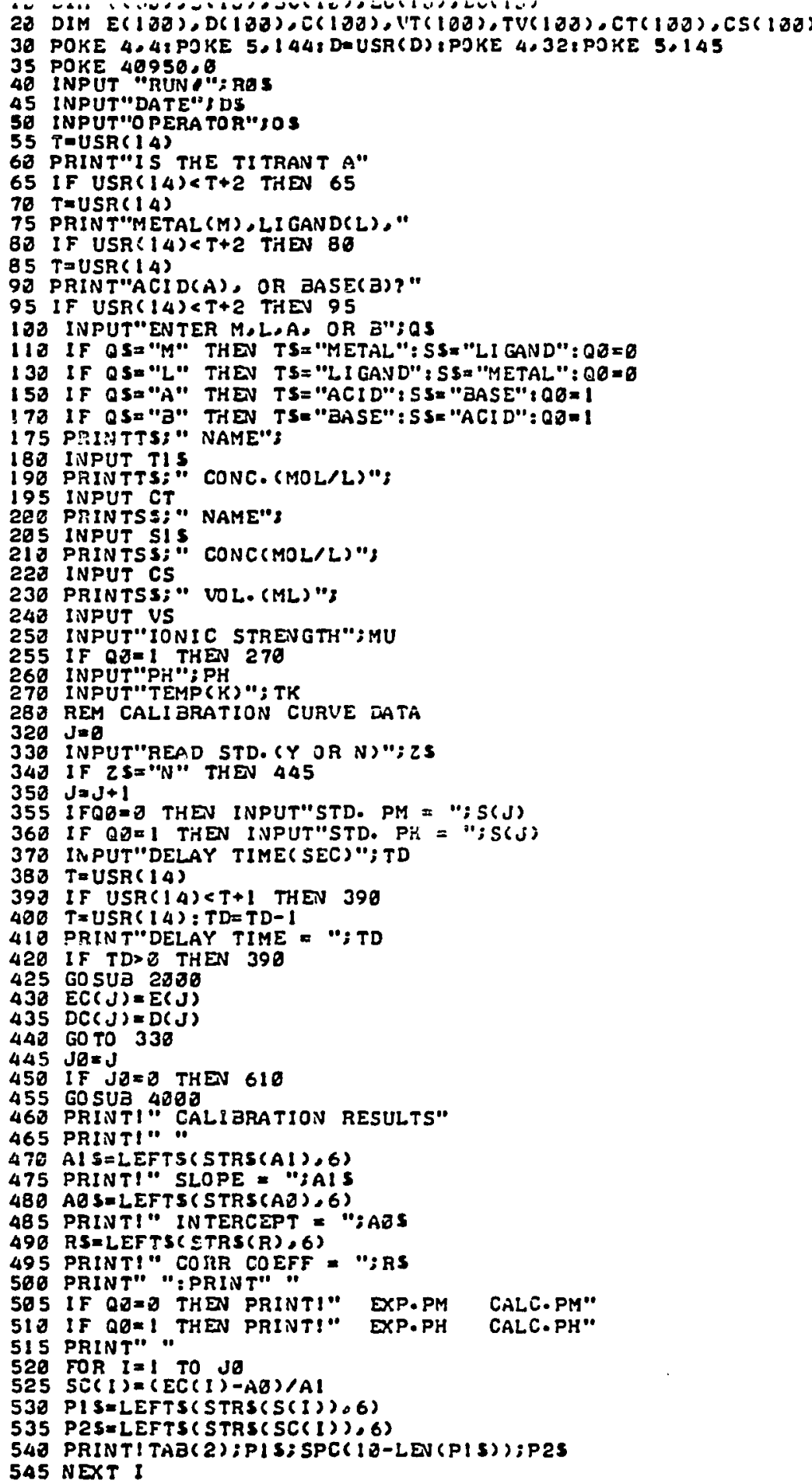




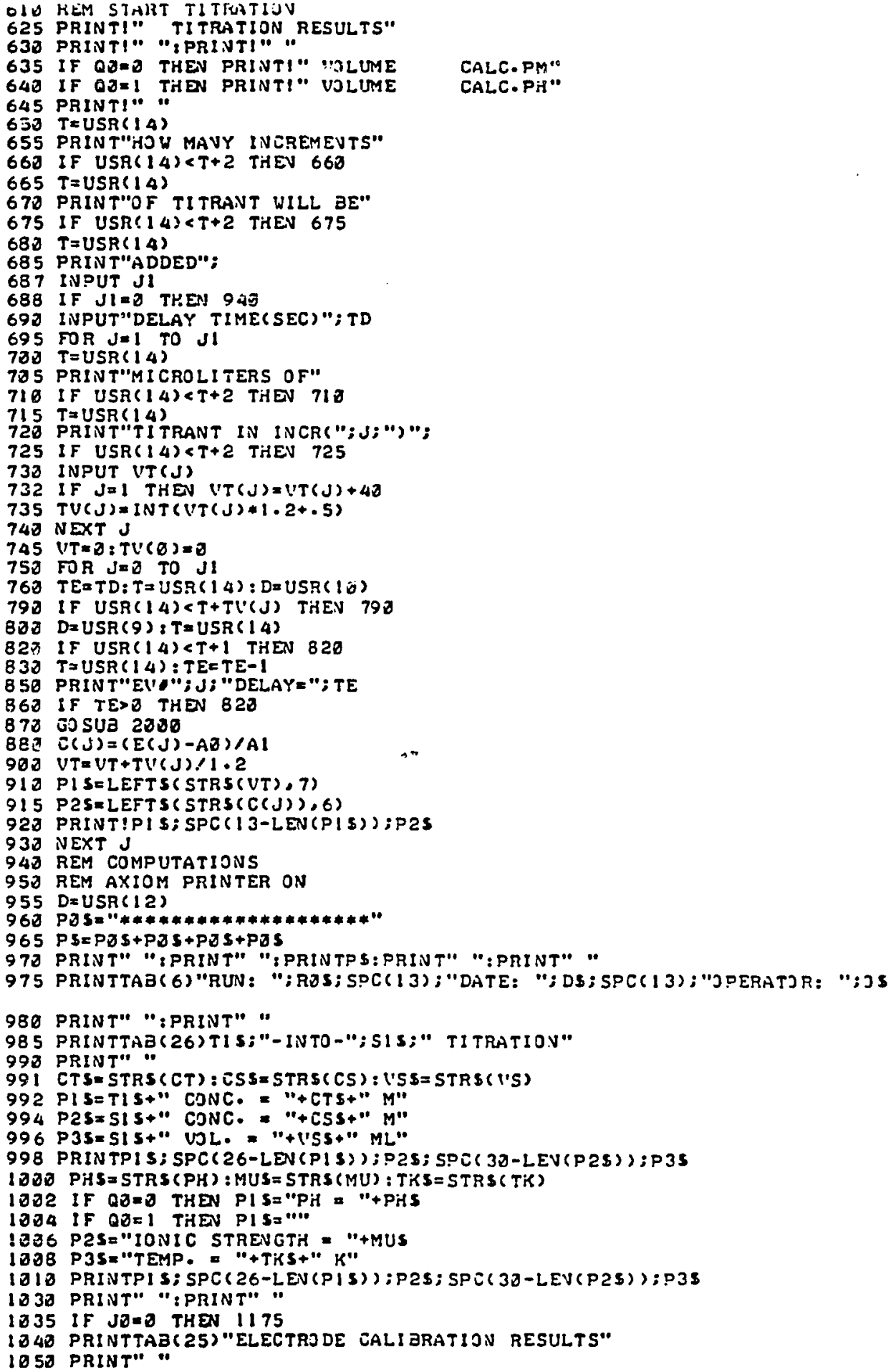




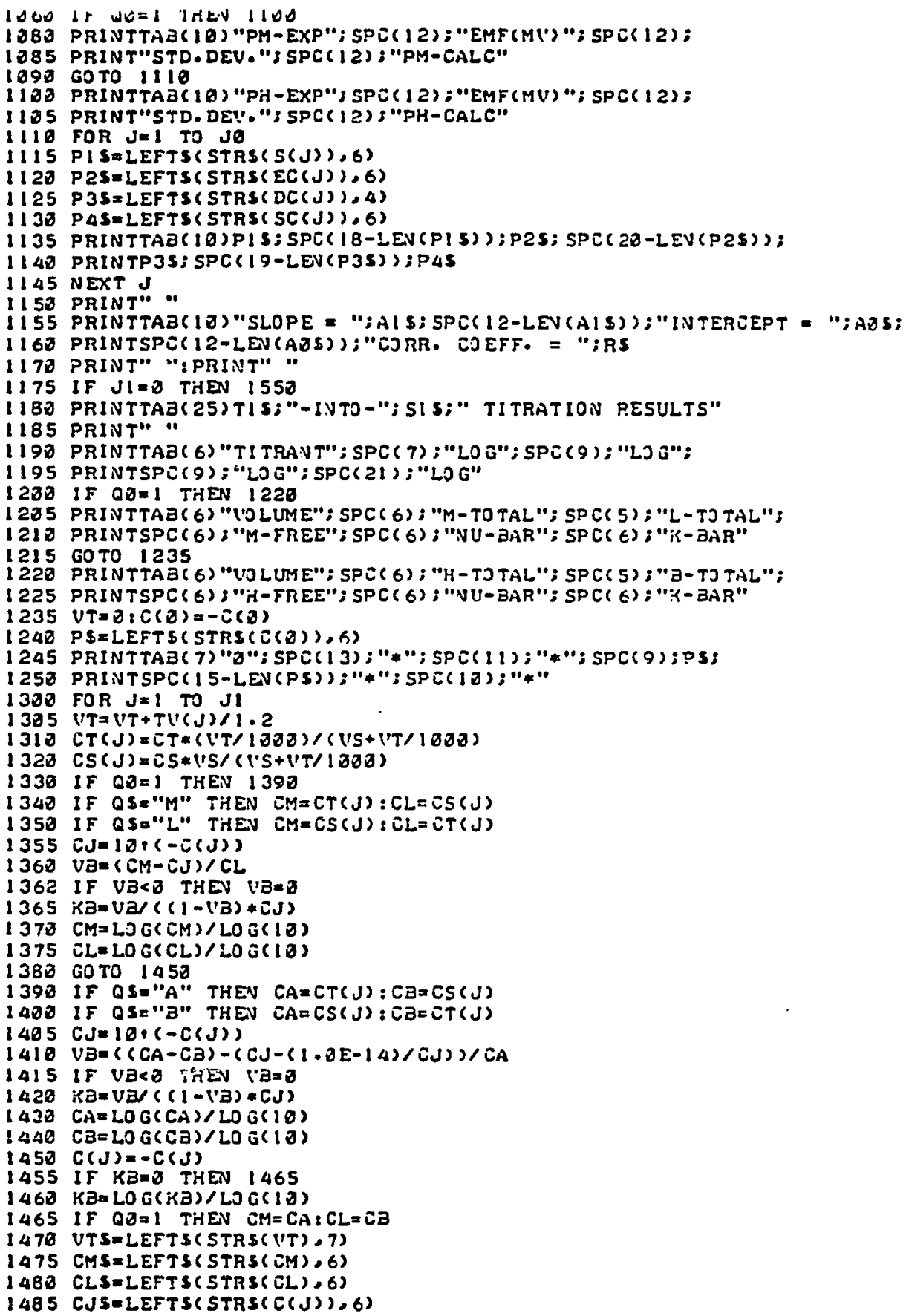




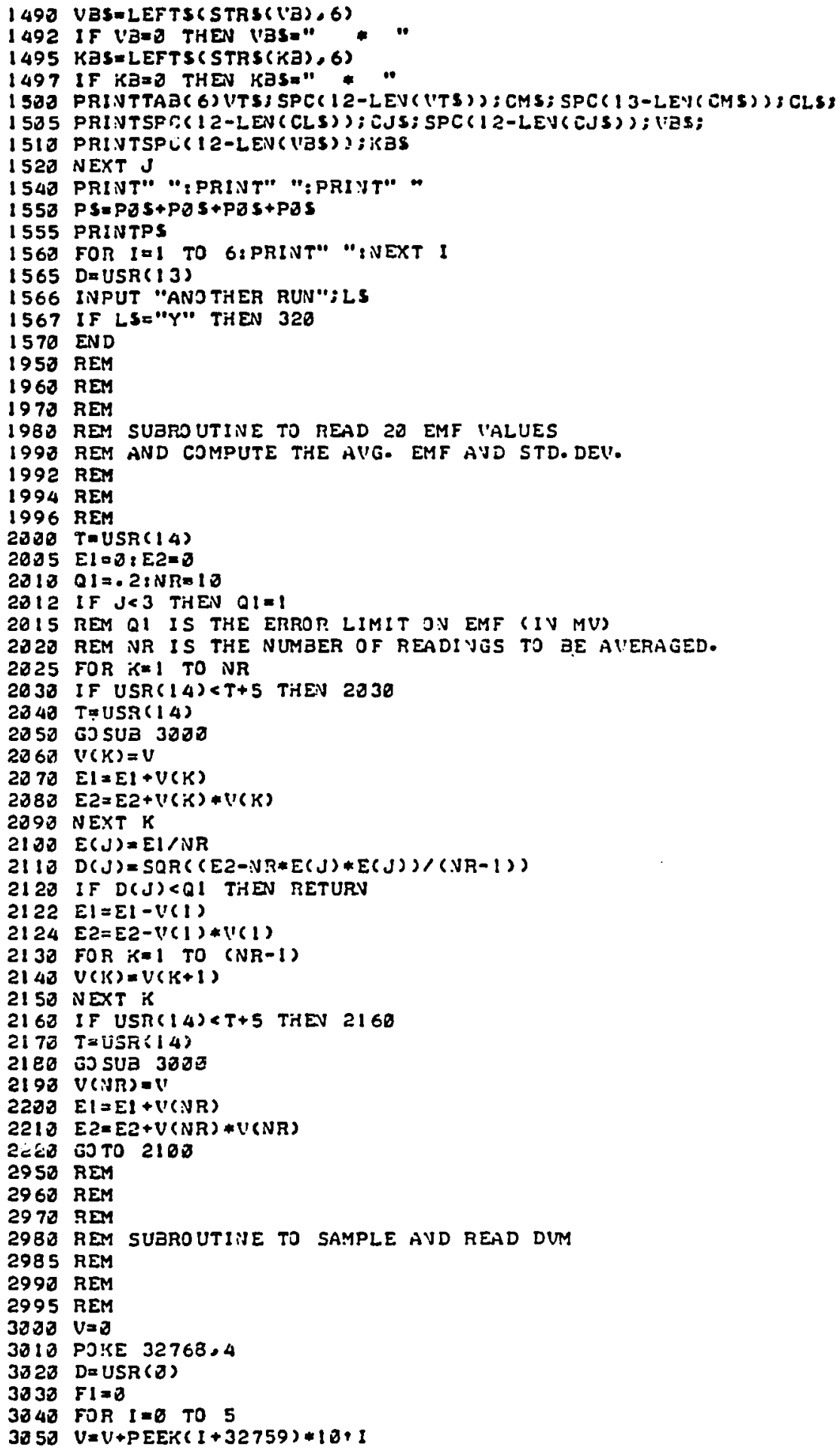




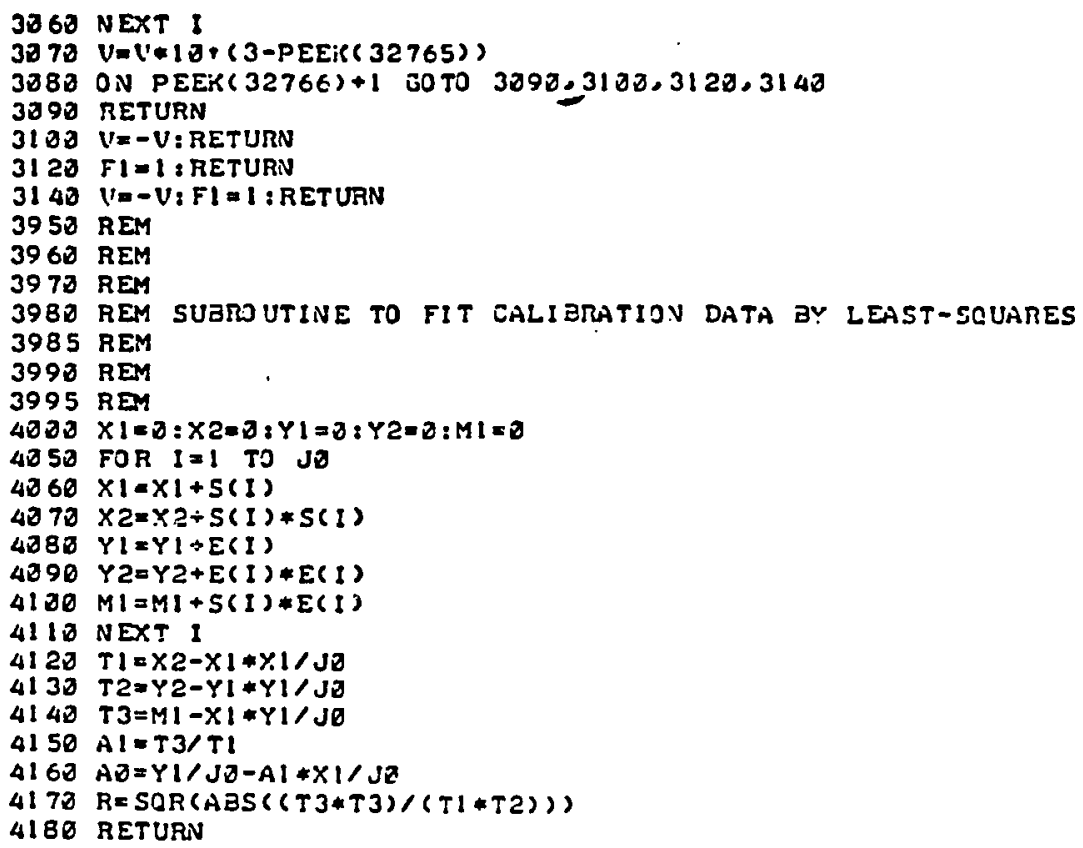


APPENDIX B: SMPLX PROGRAM LISTING

This program, written in Basic for the Rockwell Aim 65 microprocessor, was used to calculate the two copper-oxalate binding constants from titration data. The calculation procedure and equations have been previously described in the Methods section. The iterative procedure minimizes a weighted, residual sum of squares (Norris, 1981). 


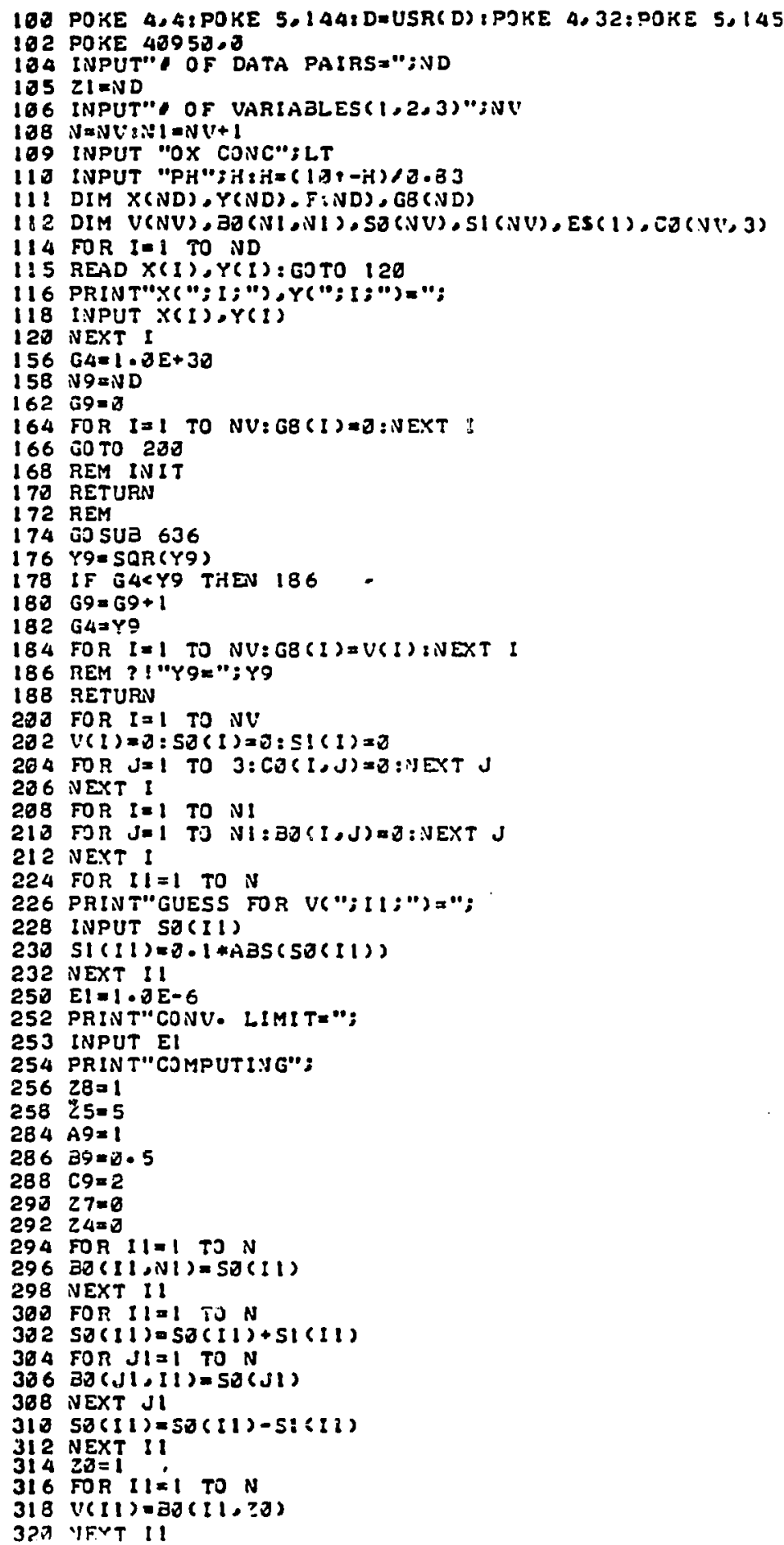




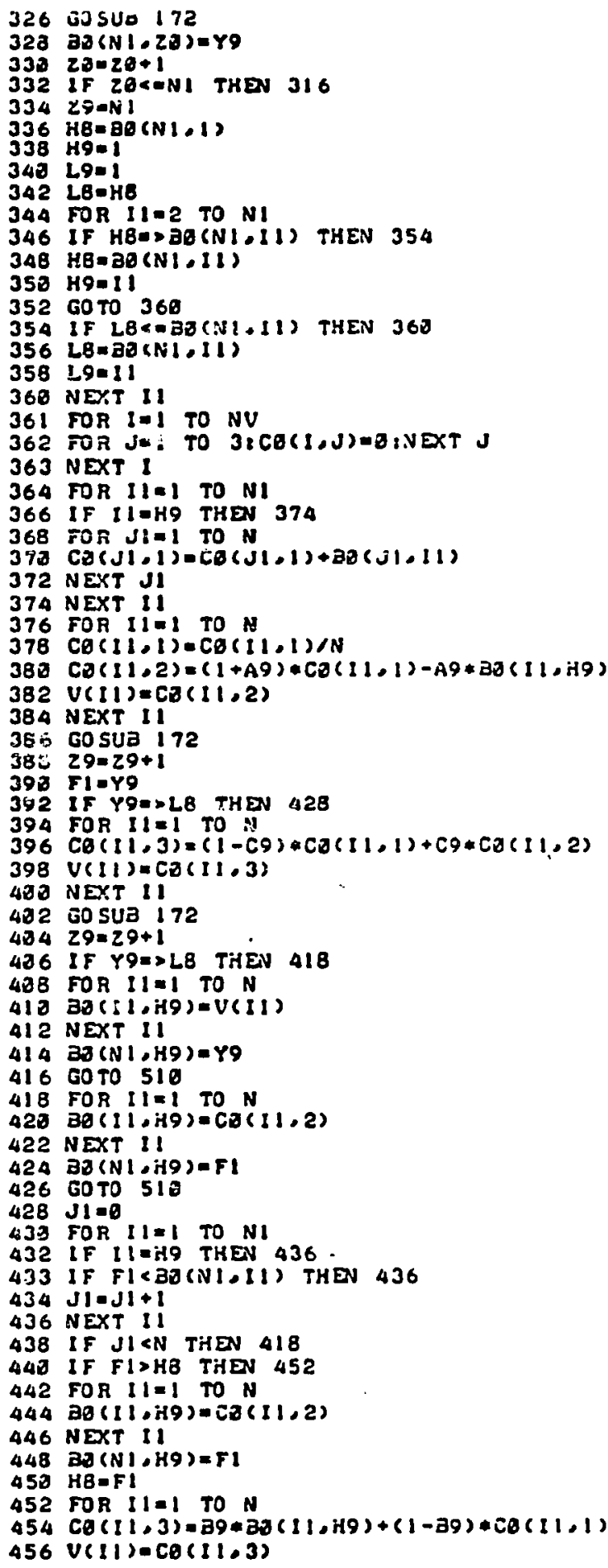




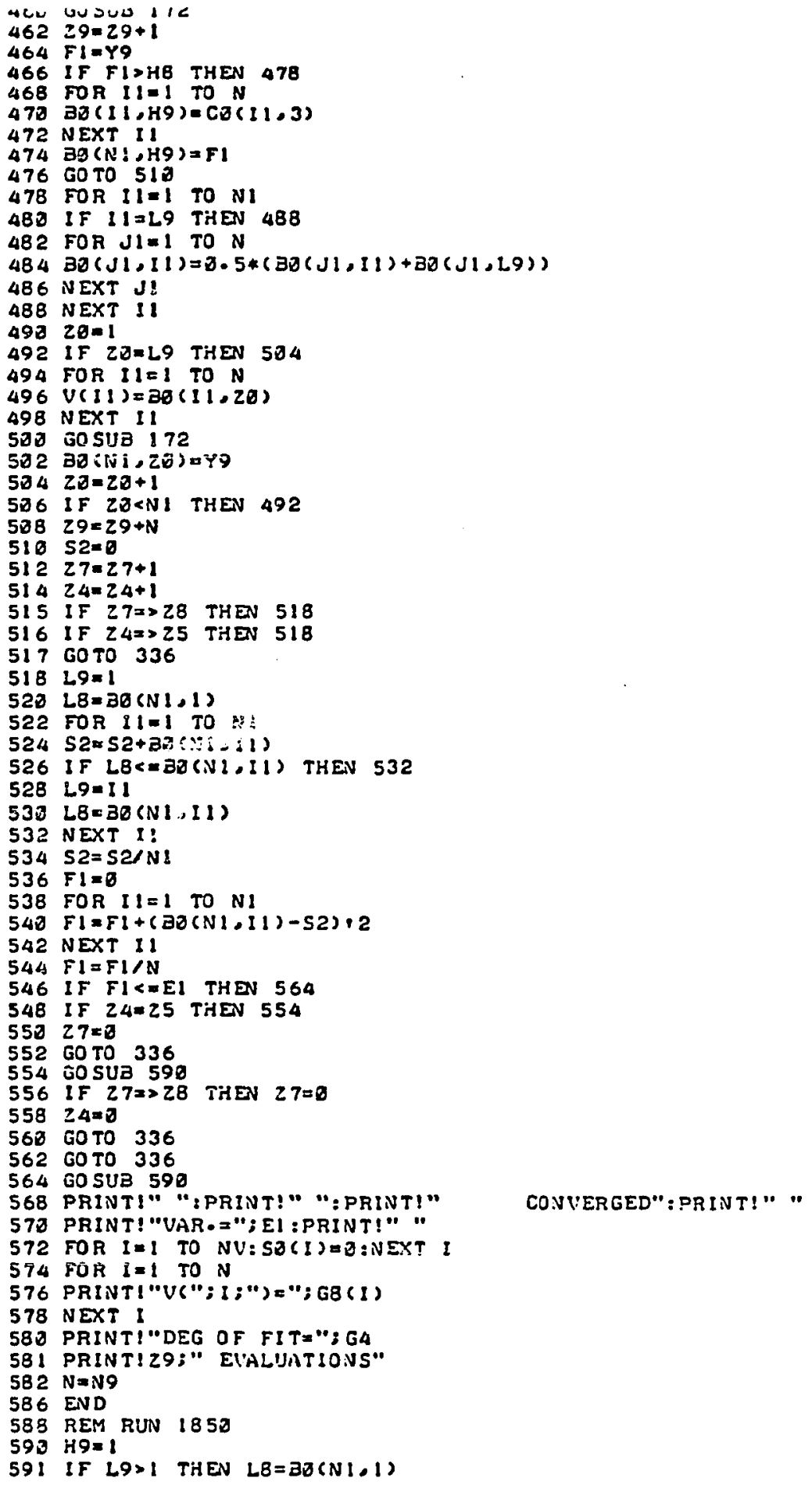




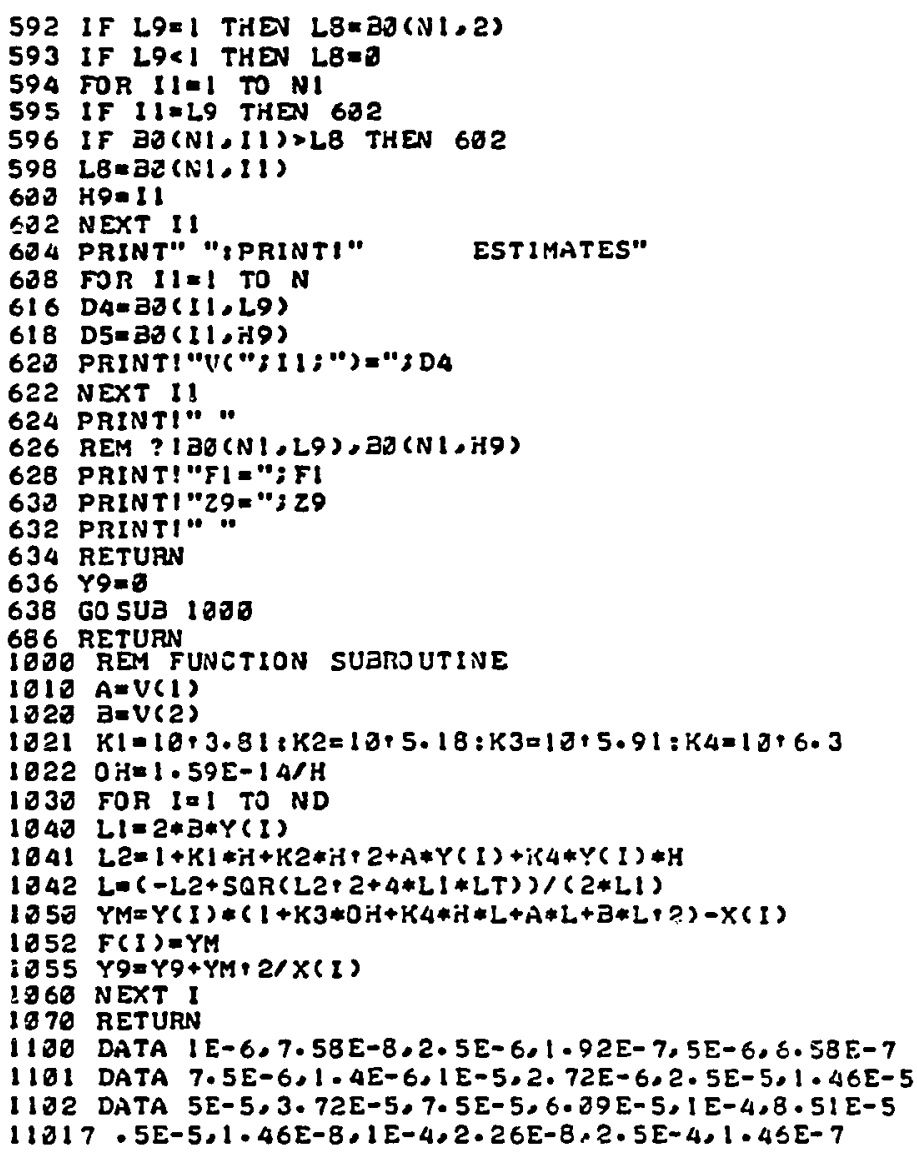


APPENDIX C: LSTSQR AND GAUSSM3 PROGRAM LISTINGS

LSTSQR was written in Fortran for use on the Honeywe11 66/20 computer (Parrish, 1982). The program will accept data entered via the teletype or will generate data assuming a Gaussian distribution of Log $\mathrm{K}$ values over a user-selected range of free metal concentrations. Nonlinear regression analysis is used to minimize a weighted residual sum of squares (Norris, 1981).

GAUSSM3 was also written in Fortran for use on the Honeywell 66/20 computer (Parrish, 1982). The program will accept data entered via the teletype, in data statements, or can generate data from Scatchard parameters. This data can be fit to a single or bimodal Gaussian distribution. Numerical integration is by the method of Gaussian quadrature, and fitting is via nonlinear regression and minimization of a weighted residual sum of squares (Norris, 1981). 


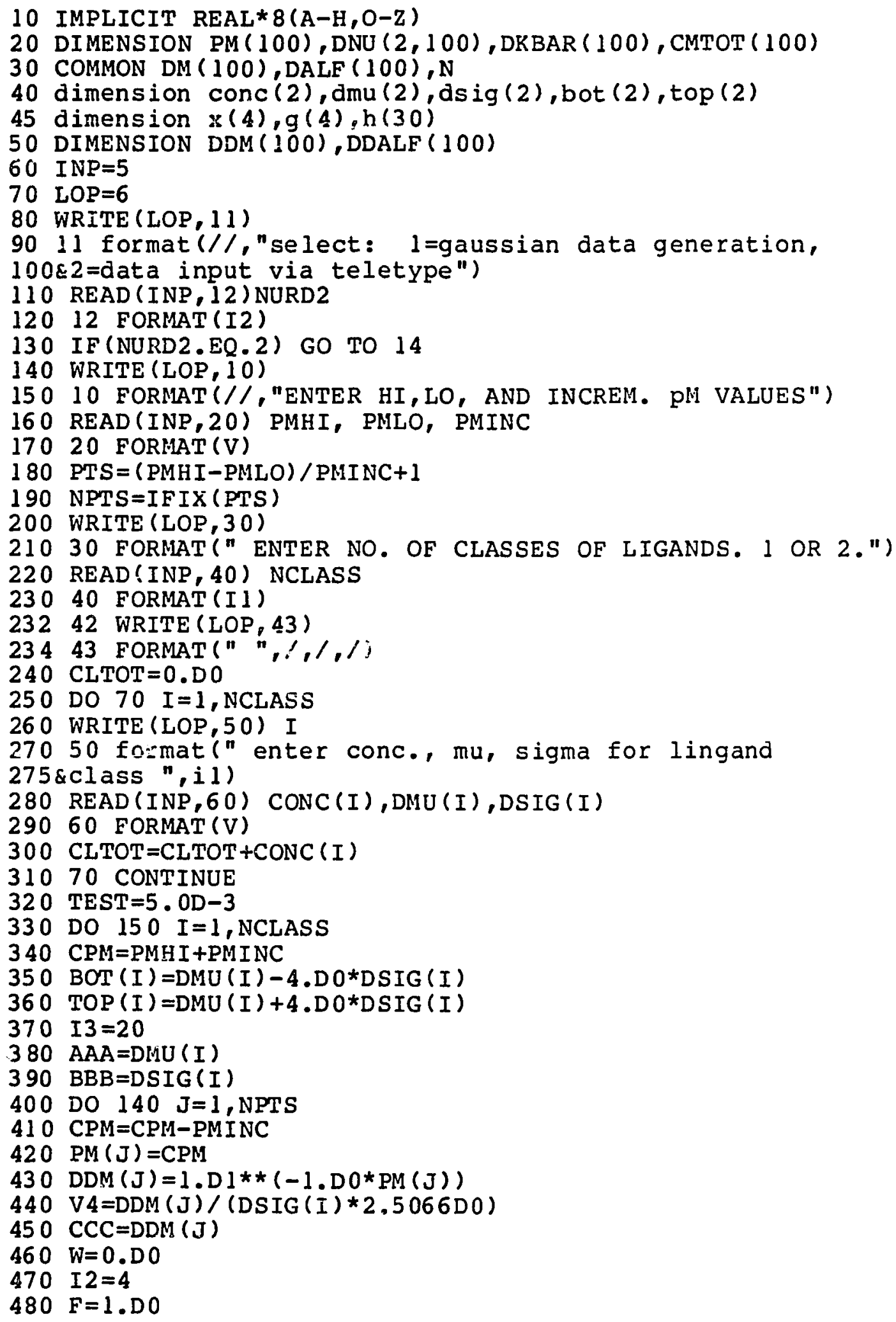




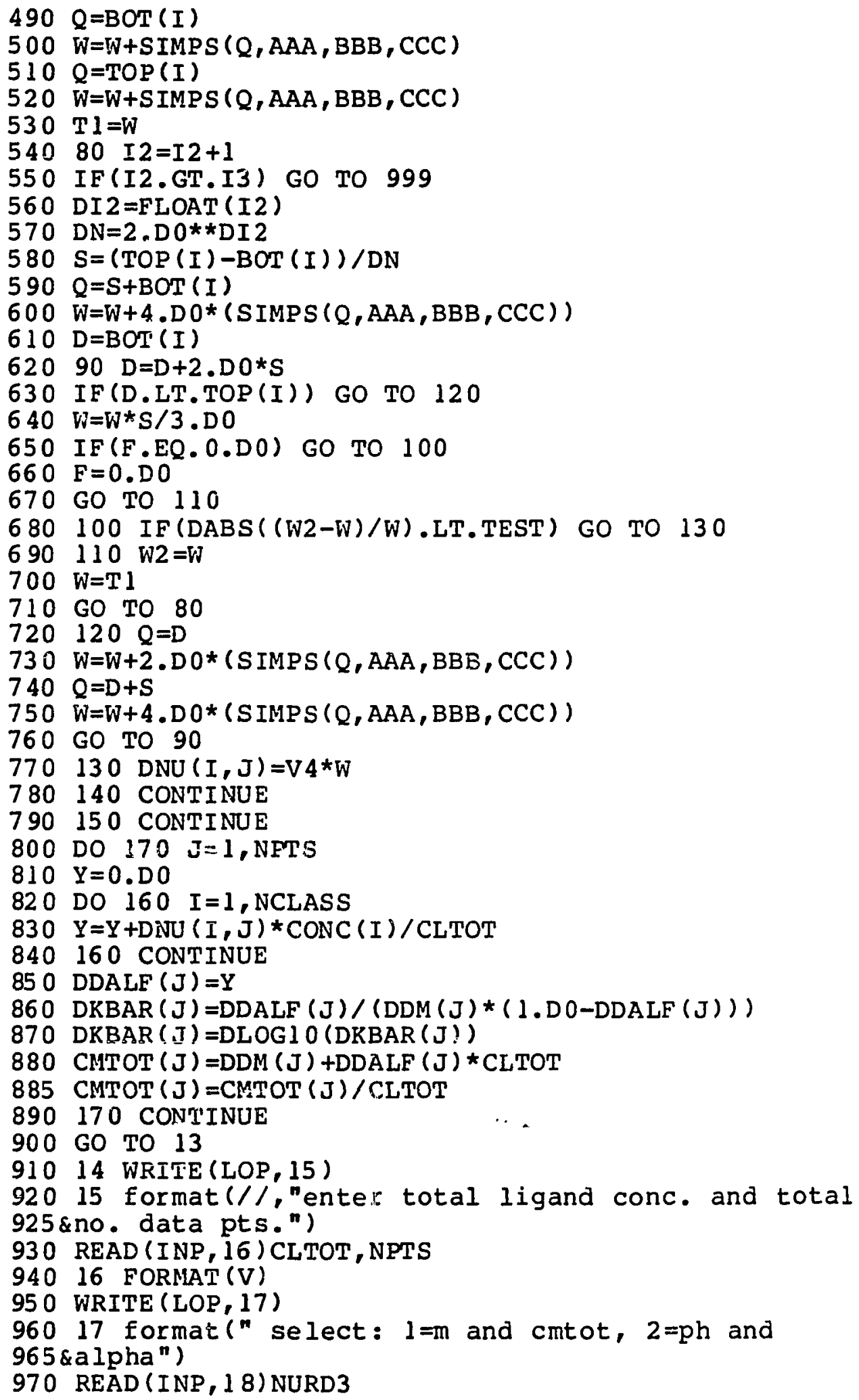


98018 FORMAT (I2)

990 IF (NURD3.EQ.2) GO TO 23

1000 WRITE (LOP, 19)

101019 FORMAT(" ENTER M AND CMTOT AS DATA PAIRS")

1020 DO $21 \mathrm{I}=1$, NPTS

1030 READ (INP, 22) DDM (I), CMTOT (I)

104022 FORMAT (V)

$1050 \operatorname{DDALF}(I)=(\mathrm{CMTOT}(\mathrm{I})-\mathrm{DDM}(\mathrm{I})) / \mathrm{CLTOT}$

$1060 \operatorname{DKBAR}(I)=\operatorname{DLOG} 10(\operatorname{DDALF}(I) / \operatorname{DDM}(I) *(1 . \operatorname{DO}-\operatorname{DDALF}(I)))$

106521 CONTINUE

1070 GO TO 13

108023 WRITE (LOP, 24)

109024 FORMAT(" ENTER pH (pM) AND ALPHA AS DATA PAIRS")

1100 DO $25 \quad I=1$, NPTS

1110 READ (INP, 26 ) PM (I), DDALF (I)

112026 FORMAT (V)

$1125 \operatorname{DDM}(I)=1 . D 1 * *(-P M(I))$

$1130 \operatorname{DKBAR}(I)=\operatorname{DLOG} 10(\operatorname{DDALF}(I) / D D M(I) *(1 . \operatorname{DO}-\operatorname{DDALF}(I)))$

1140 CMTOT $(I)=D D M(I)+D D A L F(I) * C L T O T$

114525 CONTINUE

115013 GO TO 7215

1160501 FORMAT (" PRINT TABLES? 1 = YES. $0=$ NO.")

1170 READ (INP, 502 ) 01

1180502 FORMAT(I1)

1190 IF (O1.EQ.0.0) GO TO 211

1200 WRITE (LOP, 720)

1210720 FOR,MAT (" ENTER I FOR LIST OF NU-BAR TO 8 PLACES")

1220 READ (INP, 721 ) NURD

1230721 FORMAT (V)

1240 IF (NURD. NE. 1)GO TO 724

12457215 CONTINUE

1250 DO $722 \quad I=1$, NPTS

1260 WRITE (LOP, 723 ) DDM (I), DDALF (I) , CMTOT (I)

1270723 FORMAT(" ",3 $(5 \mathrm{X}, 1 \mathrm{PE} 10.3))$

1280722 CONTINUE

1285 ₹० TO 42

1290724 WRITE $(L O P, 180)$

1300180 FORMAT (" DATA LOG FREE TOTAL NUBAR LOG")

1310 WRITE (LOP, 190)

1320190 format(" point metal metal

$1325 \&$ kbar", 1$)$

1330 DO $210 \mathrm{~J}=1$, NPTS

1340 WRITE (LOP, 200$) \mathrm{J}, \operatorname{PM}(\mathrm{J}), \mathrm{CMTOT}(\mathrm{J}), \operatorname{DDALF}(\mathrm{J}), \operatorname{DKBAR}(\mathrm{J})$

1350200 FORMAT ( $" n, I 3,5 X_{i}$ F5 , 1, 3X, IPD 9.2, 2X, 0PF6.3, 2X,F6.2)

1360210 CONTINUE

1370211 CONTINUE

1380 WRITE (LOP, 715)

1390715 FORMAT (//, "NONL INEAR, LEAST-SQUARES ANALYSIS." )

1400 WRITE (LOP, 716)

1410716 format("use $n ' s$ and $k$ 's that generated data as $1415 \&$ first guesses." )

1420 IMPLICIT REAL*8(A-H,O-Z) 
1430 EXTERNAL FUN

1440 DATA $M / 4 /$

1450 WRITE (LOP, 400)

1460400 FORMAT (//, "ENTER $\mathrm{n} 1, \mathrm{~K} 1, \mathrm{n} 2, \mathrm{~K} 2$ ")

1470 READ (INP, 700)X

1480700 FORPATT (V)

1490712 WRITE (LOP, 707)

1500707 format (//, "enter starting data point index for 1505 \& scat chard analys is")

1510 READ (INP, 708) NSTART

1520708 FORMAT(I2)

$1530 \mathrm{~J}=0$

i540 DO 709 I=NSTAR'N, NPTS

$1550 \mathrm{~J}=\mathrm{J}+1$

$1560 \mathrm{DM}(\mathrm{J})=\mathrm{DDM}(\mathrm{I})$

$1570 \operatorname{DALF}(\mathrm{J})=\operatorname{DDALF}(I)$

1580709 CONTINUE

$1590 \quad \mathrm{~N}=\mathrm{J}$

1600 EST $=0 . D 0$

1610 DEPS $=1 . \mathrm{D}-4$

16202 WRITE (LOP, 402)

1630402 format ("enter no. iterations. - 1=values, $0=$ stop,

$1635 \& 1=$ another analysis." )

1650 READ (INP, 403) ITER

1660403 FORMAT (I3)

1670 IF(ITER.EQ.0) GO TO 99

1680 IF (ITER.EQ.-1) GO TO 98

1690 IF (ITER.EQ.1) GO TO 211

1700 DO $4 \mathrm{I}-1, \mathrm{M}$

$1710 \& X(I)=D S Q R T(X(I))$

1720 CALL FMFP (FUN, M, X, SSE, G,EST, DEPS, ITER, IER, H)

1730 DO $3 \quad I=1, M$

$17403 \times(I)=X(I) * * 2$

1750 WRITE (LOP, 404) IER, SSE, (X (I), I=1,M), (G(I), I=1,M)

1760404 format $(/ x, 1$ herror code, $i 3 / 17 \mathrm{~h}$ sum of squares

$1765 \&=, 1 \mathrm{pe} 13.5 / 3 \mathrm{~h} \quad \mathrm{x}=, 1 \mathrm{p} 4 \mathrm{e} 15.5 / 3 \mathrm{~h} \mathrm{~g}=, 1 \mathrm{p} 4 \mathrm{e} 15.5 /)$

1780 GO TO 2

179098 WRITE (LOP, 92 ) X

180092 FORMAT (5H IPRED, 1P4E $15.5 / /$ )

1810 DO $198 \quad I=1, N$

1820 PRED $=(X(1) * X(2) * D M(I) /(1 . D 0+(X(2) * D M(I))))+$

$1830 \&(X(3) * X(4) * D M(I) /(1 . D 0+(X(4) * D M(I))))$

1840198 WRITE (LOP, 91$)$ DM (I), DALF (I), PRED

185091 FORMAT ( $4 X, 1$ P3E 13.2)

1860 GO TO 2

1870999 WRITE (LOP, 900)

1880900 format ("no conv. in 16 iter. incr. i3 in $1890 \&$ LINE 0280 OR INCREASE TEST IN LINE $0230^{\prime \prime}$ )

190099 STOP

1910 END

1920 SUBROUTINE FUN $(M, X X, F, G)$

1930 IMPLICIT REAL * $8(\mathrm{~A}-\mathrm{H}, \mathrm{O}-\mathrm{Z})$ 
1940 COMMON DM (100), DALF $(100), N$

1950 DIMENSION $X(4), G(1), X X(1)$

1960 DATA DZ,DE/0.DO,1.DO/

1970 DO $100 \quad I=1, M$

$1980100 \times(I)=X X(I) * * 2$

$1990 \quad F=D Z$

2000 DO I I $I=1, M$

$20101 G(I)=D Z$

2020 DO $2 \quad I=1, N$

$2030 \mathrm{WT}=\mathrm{DE} / \mathrm{DALF}(\mathrm{I})$

$2040 \mathrm{D} 1=\mathrm{DE} /(\mathrm{DM}(\mathrm{I})+\mathrm{DE} / \mathrm{X}(2))$

$2050 \mathrm{D} 2=\mathrm{DE} /(\mathrm{DM}(\mathrm{I})+\mathrm{DE} / \mathrm{X}(4))$

$2060 P R E D=D M(I) *(X(1) * D 1+X(3) * D 2)$

2070 ERROR $=(\mathrm{DALF}(\mathrm{I})-\mathrm{PRED})$

$2080 \mathrm{~F}=\mathrm{F}+\mathrm{WT} *(\mathrm{ERROR} * \star 2)$

2090 CONS $=-2$. DO*ERROR *WT

$2100 G(1)=G(1)+D M(I) * D 1 * C O N S * 2 . D 0 * X X(1)$

$2110 G(2)=G(2)+X(1) * D M(I) * D 1 * * 2 / X(2) * \star 2 * C O N S * 2 . D 0 * X X(2)$

$2120 \mathrm{G}(3)=\mathrm{G}(3)+\mathrm{DM}(\mathrm{I}) * \mathrm{D} 2 * \mathrm{CONS} * 2 . \mathrm{D} 0 * \mathrm{XX}(3)$

$2130 \mathrm{G}(4)=\mathrm{G}(4)+\mathrm{X}(3) * \mathrm{DM}(\mathrm{I}) * \mathrm{D} 2 * * 2 / \mathrm{X}(4) * * 2 * \mathrm{CONS} * 2 . \mathrm{D} 0 * \mathrm{XX}(4)$

21402 CONTINUE

2150 RETURN

2160 END

2170 FUNCTION SIMPS ( $Q, A A A, B B B, C C C)$

2180 V5 $=1 . D 1 * * Q /(1 . D 0+C C C * 1 . D 1 * * Q)$

2190 V6 $=\operatorname{DEXP}(-5 \cdot \mathrm{D}-1 *((\mathrm{AAA}-Q) / \mathrm{BBB}) * \star 2)$

2200 SIMPS $=\mathrm{V} 5$ *V6

2210 RETURN; END

2220 SUBROUTINE FMFP (FUNCT, N , X, F , G,EST, EPS, LIMIT, IER, H)

2230 IMPLICIT REAL* $8(\mathrm{~A}-\mathrm{H}, \mathrm{O}-\mathrm{Z})$

2240 COMMON DM $(100), \operatorname{DALF}(100)$

2250 DIMENSION $\mathrm{X}(1), \mathrm{G}(1), \mathrm{H}(1)$

2260 KOUNT $=0$

2270 CALL FUNCT $(N, X, F, G)$

2280 IER $=0$

$2290 \quad \mathrm{~N} 2=\mathrm{N}+\mathrm{N}$

$2300 \mathrm{~N} 3=\mathrm{N} 2+\mathrm{N}$

$2310 \quad \mathrm{~N} 31=\mathrm{N} 3+1$

$23201 \mathrm{~K}=\mathrm{N} 31$

2330 DO $4 \mathrm{~J}=1, \mathrm{~N}$

$2340 \mathrm{H}(\mathrm{K})=1$. DO

$2350 \mathrm{NJ}=\mathrm{N}-\mathrm{J}$

2360 IF (NJ) $5,5,2$

23702 DO $3 \mathrm{~L}=1$, NJ

$2380 \mathrm{KL}=\mathrm{K}+\mathrm{L}$

$23903 \mathrm{H}(\mathrm{KL})=0 . \mathrm{DO}$

$2400 \quad 4 \quad K=K L+1$

24105 KOUNT=KOUNT +1

2420 KNT $=$ KOUNT

2430 OLDE $=F$

2440 DO $9 \mathrm{~J}=1, \mathrm{~N}$

$2450 \quad \mathrm{~K}=\mathrm{N}+\mathrm{J}$ 


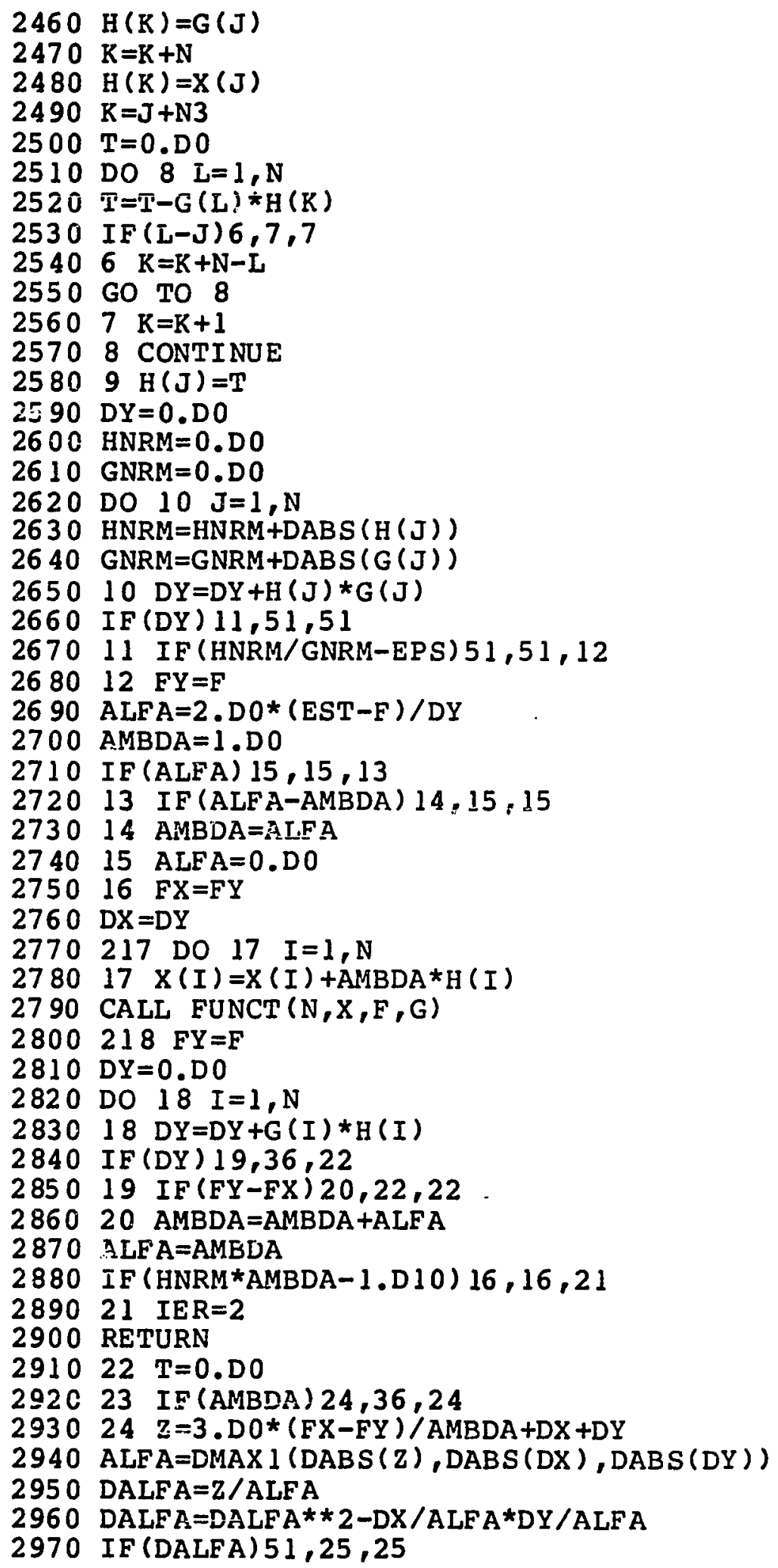




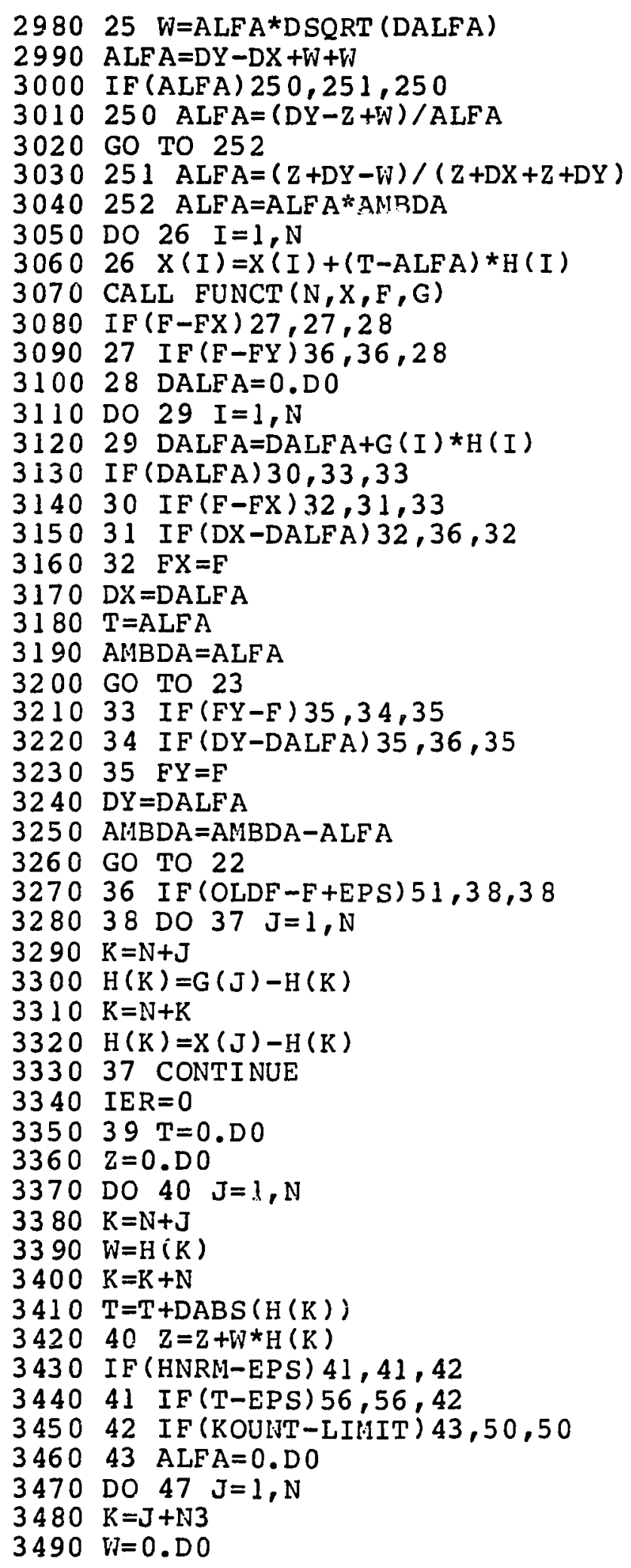




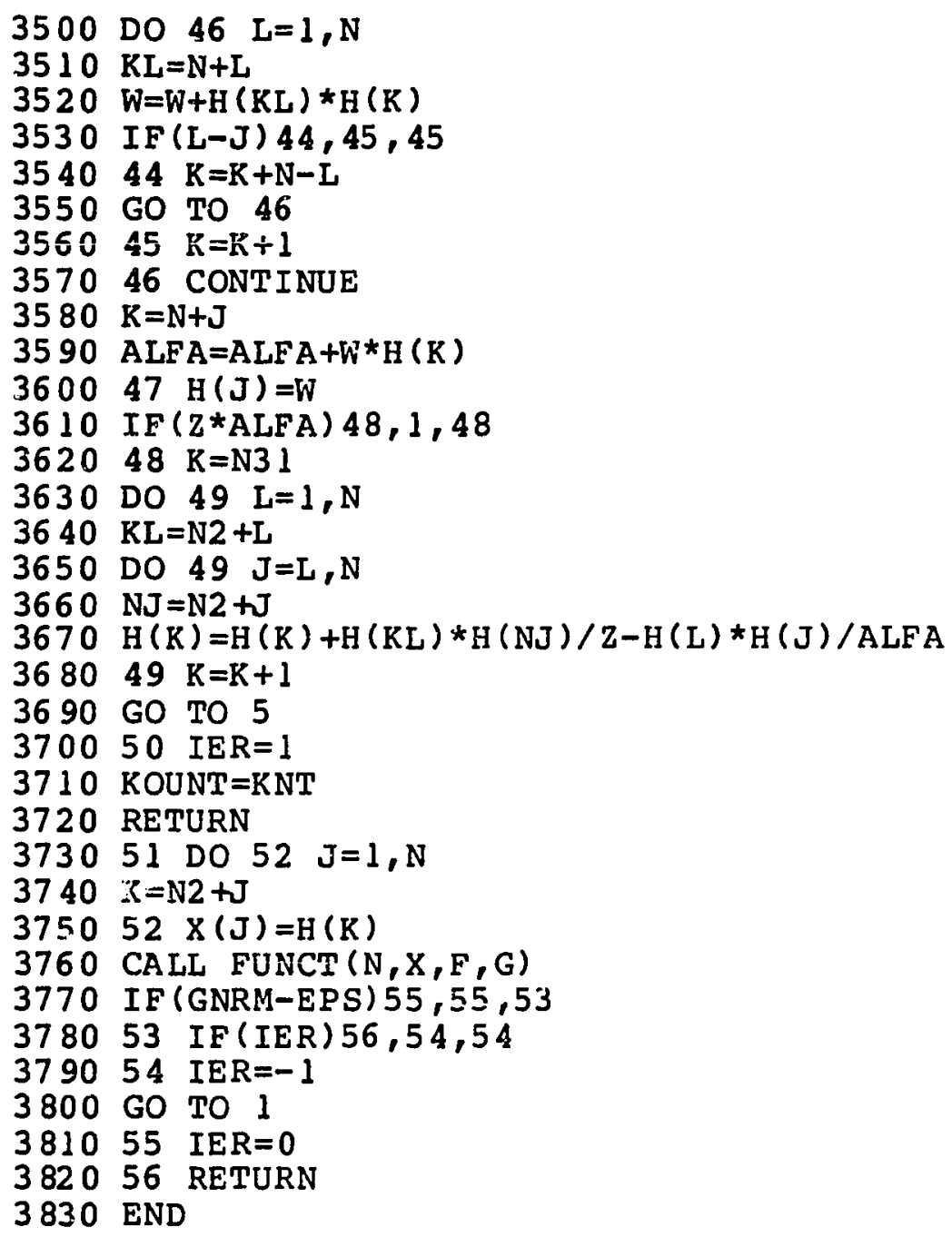




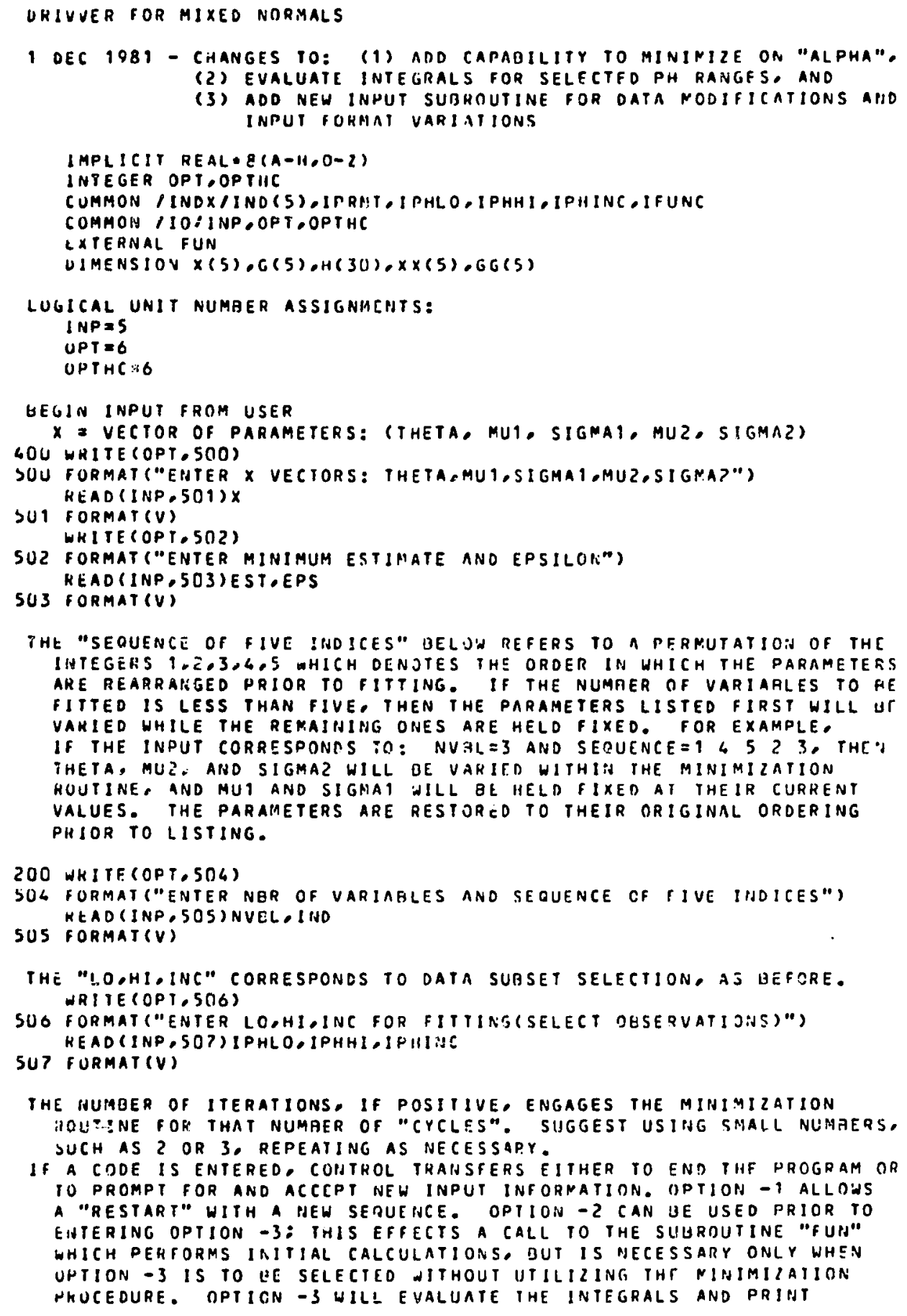

THE "LOOHI. INC" CORRESPONDS TO DATA SUBSET SELECTION, AJ BEFORE. WRITE (OPI, 5O6)

SUO FORMAT ("ENTER LO.HI,INC FOR FITIING(SELECT DGSERVATIOAS)") KEAD(INP, SOT)IPHLO,IPHHI,IPIIIISC

SUT FURMAT (V)

IHE HURBER OF ITERATIONS, IF POSITIVE, ENGAGES THE MINIMIZATION MQLP: NE FOF THAT NUMAER OF "CYCLES". SUGGEST USING SMALL NUMAERS, SUCH AS 2 OR 3, REPEATING AS NECESSAPY.

If A CDDE IS ENTERED. COHTROL TRANSFERS EITHER TO END IHF PROGRAM OR TO PROMPI FOR AND ACCCPT NEW INPUT INF ORMATION. OPTION - I ALLOWS a "Restart" WITH a Hew SERUENCE. OPIION - 2 CAN be USED PRIOR TO ENTERING OPTION -3: THIS EFFECTS A CALL TO THE SULRDUTINE "FUA" WHICH PEHTORMS IRITIAL CALCULATIONS, BUT IS NECESSARY ONLY WHEN UHTION - 3 IS TO LE SELECTED WITHOUT IITILIZING THF MINIMILAIION NKUCEDURE. OPTICN -3 WILL EVALUATE THE INTEGRALS AND PRINT 


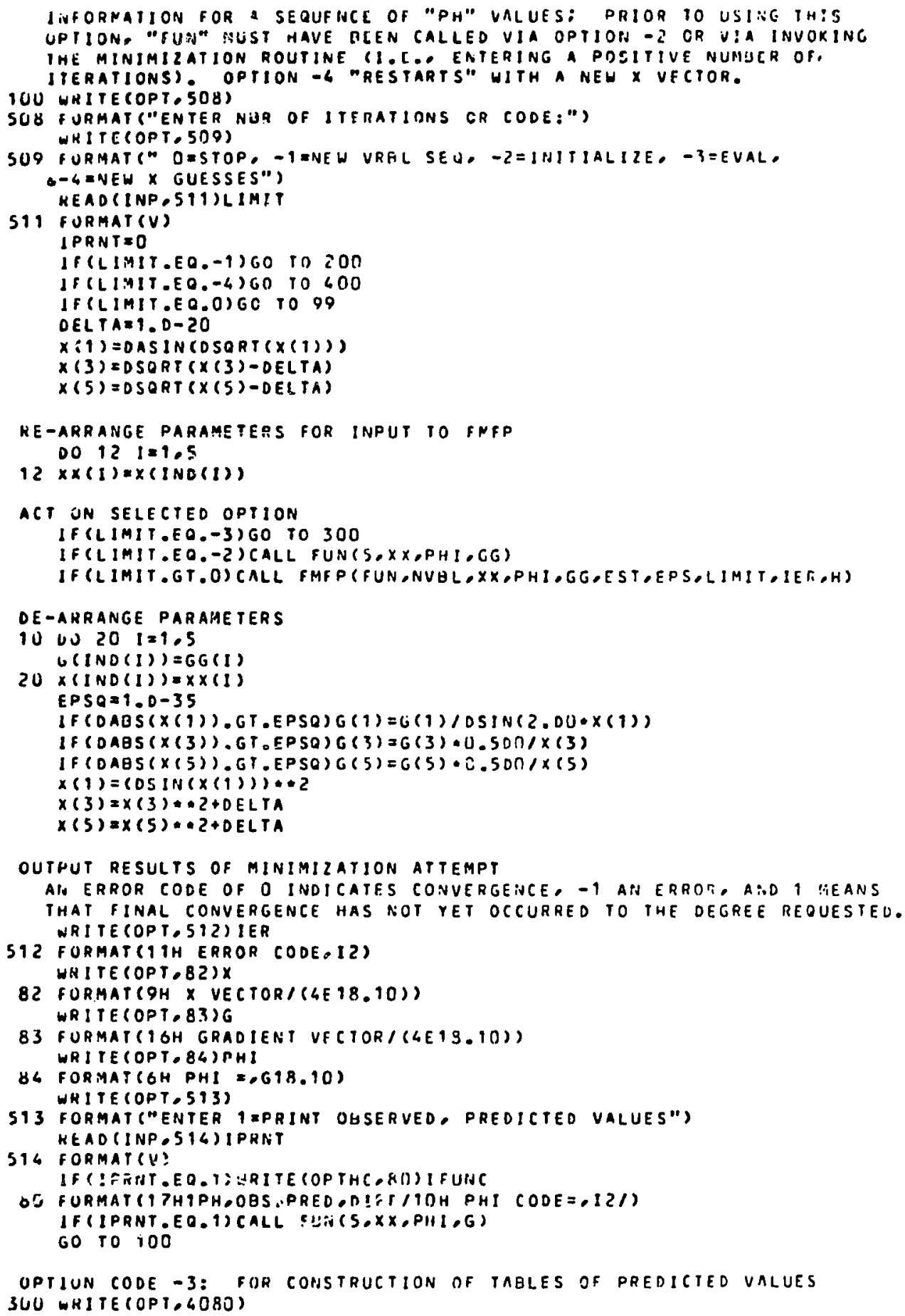




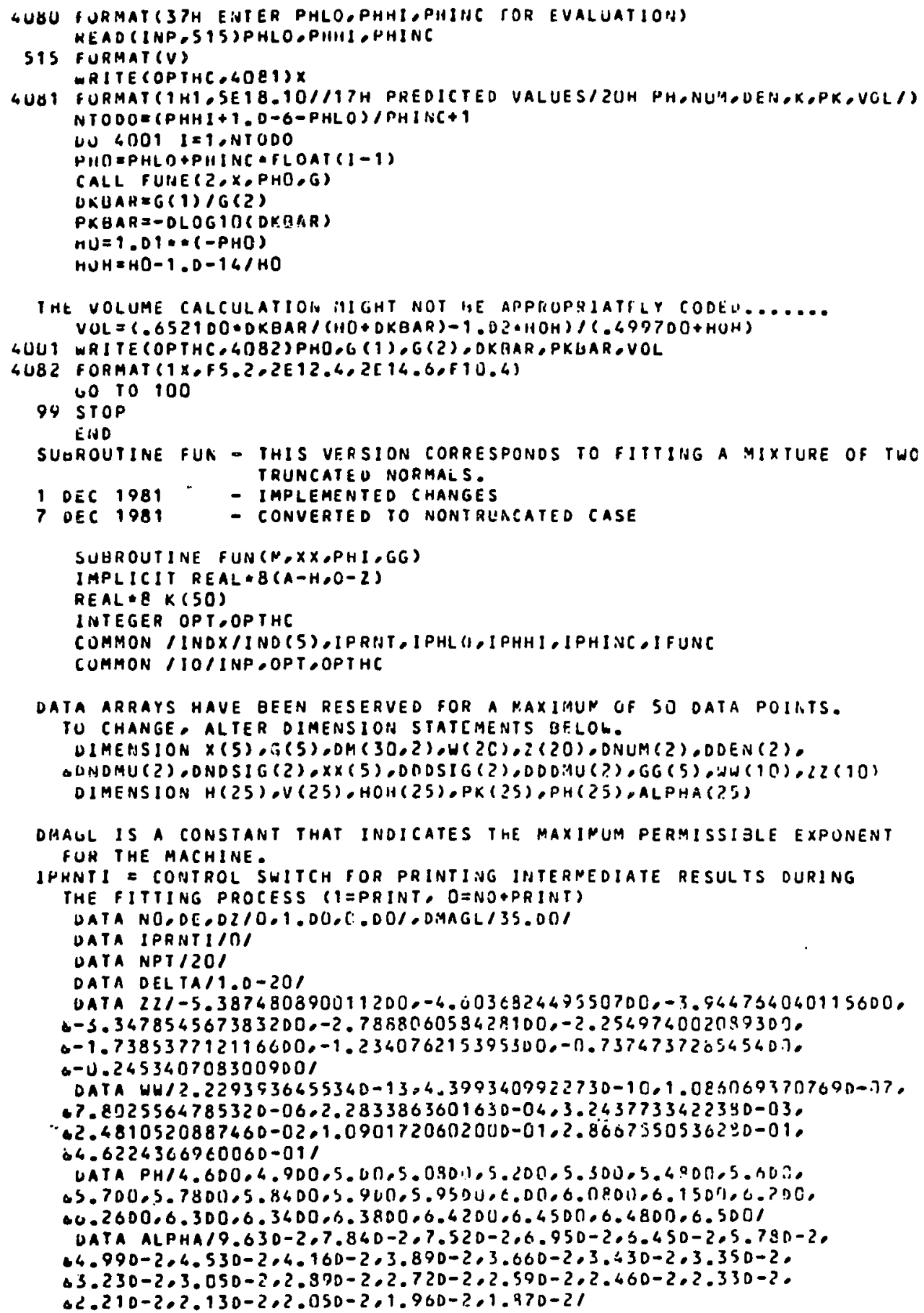

DATA ARRAYS HAVE GEEN RESERVED FOR A MAXIMUN OF 50 DATA POITTS. TU CHANGE. ALTER DIMENSION STATEMENTS BELOH. DIMEASION $X(5), G(5), O M(30,2), W(2 C), 2(20)$, DNUM( 2$), D D E N(2)$.

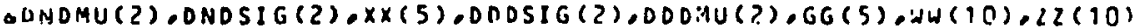
DIMENSION H(25), V(25), HOH(25), PK(25), PH(25),ALPHA(?5)

DHALL IS a CONSTANT THAT INDICATES THE MAXIMUM PERMISSIBLE EXPONENT FUA THE MACHINE.

IPKNTI E CONTROL SWITCH FOR PRINTING INTERMEDIATE RESULTS DURING THE FITTING PROCESS (I=PRINT, $D=N D+P R I N T)$

DATA NO.DE.OZ/O.1.DO,C.DO/.DMAGL/35.DOI

DATA IPRNTIIOI

DATA NPT/20/

DATA DELTA/1.0-20I

UATA 221-5.3874808900112000-4.003632447550700,-3.946734040115600。 $0-3.347854567383200,-2.7868060534289100,-2.25497400209930 \mathrm{~J}$. $0-1.738537792116600,-1.234076215395300 .-0.73767372654540 .7$. $-U .2453407083009001$

DATA WHIZ.2293936655340-13.4.3993409922730-10.1.0830693707690-777. $.7 .8025564785320-06.2 .2833863601630-04,3.2437733422390-03$. $\because 42.4810520887460-02.1 .0901720602000-01.2 .8607550536200-01$. $04.6224366960060-011$ UATA PH/4.600.4.900,5.00,5.0301,5.200,5.300,5.4.900.5.40.30 Q5.700.5.7800.5.8400.5.900.5.950U.6.00.6.08011.6.150r.,0.7D0. 0.2600 .6 .300 .6 .3600 .3 .3800 .6 .4200 .6 .4500 .6 .4800 .6 .5001 DATA ALPHA19.630-2.7.840-2.7.520-2.6.950-2.3.450-2.5.790-2. $64.990-2.4 .530-2.4 .160-2,3.890-2,3.660-2,3.430-2.3 .350-2$. $43.230-2.3 .050-2.2 .390-2.2 .720-2.2 .590-2.2 .460-2.2 .330-2$. $02.210-2.2 .130-2,2.050-2,1.960-2,1.970-21$ 


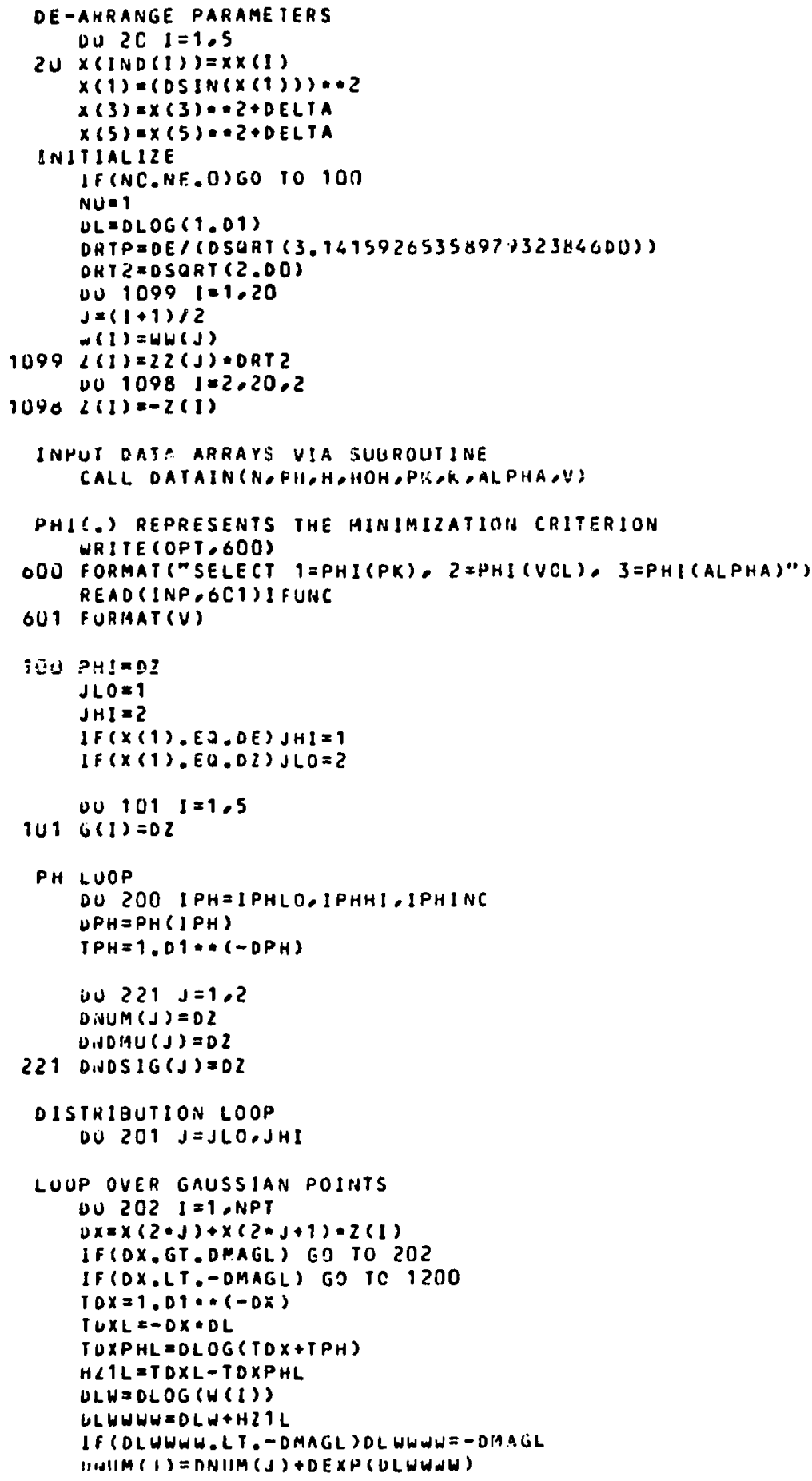




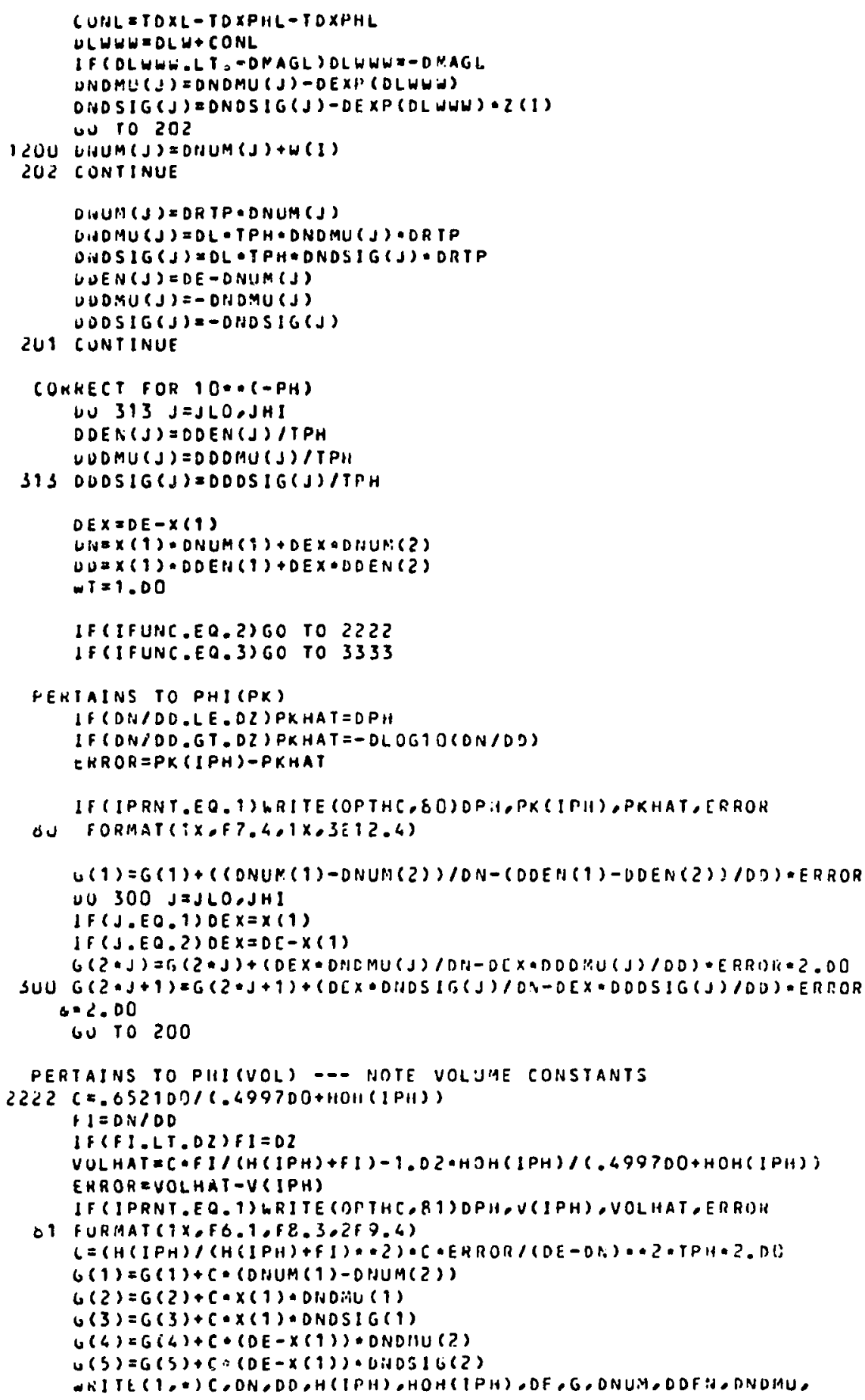




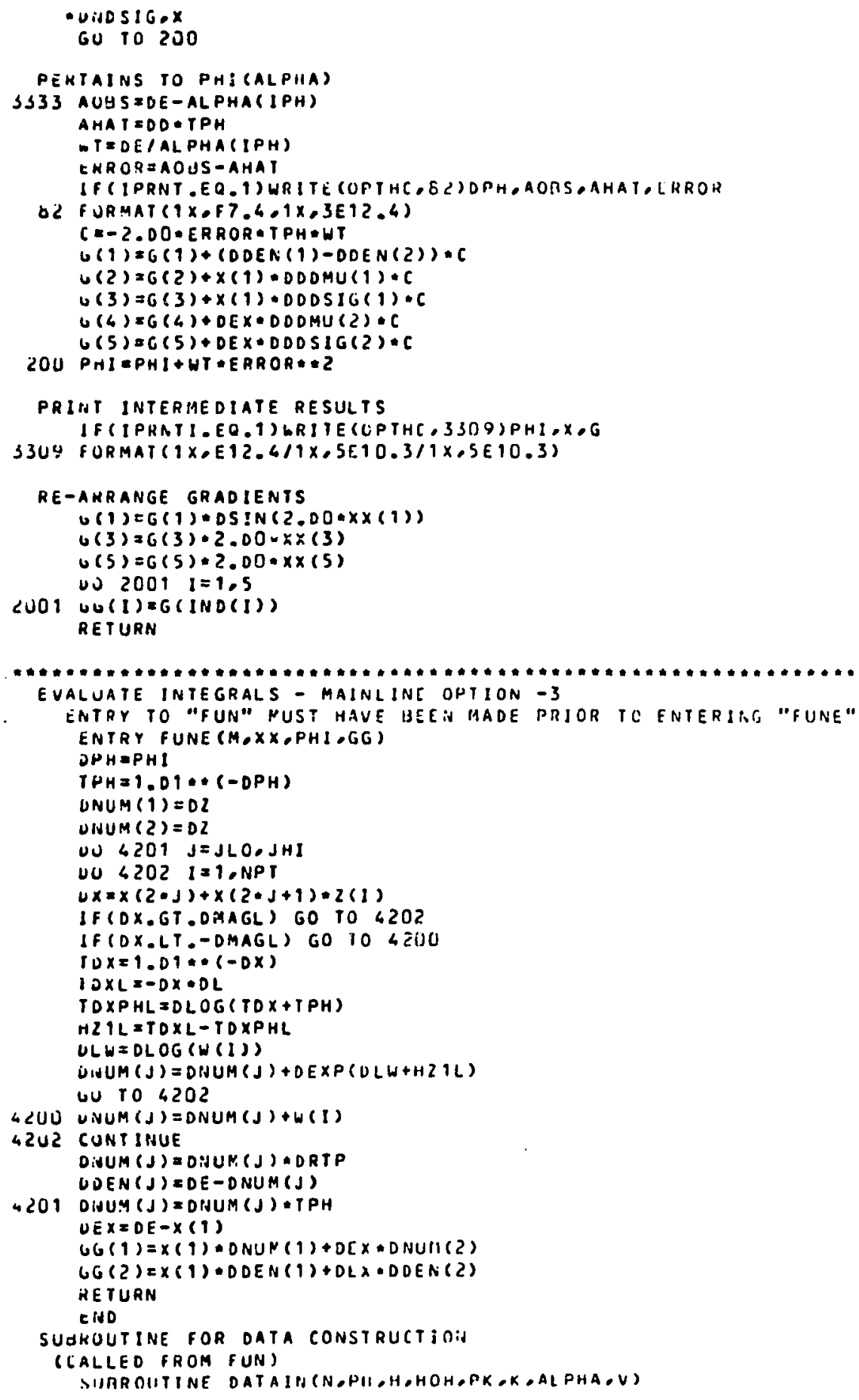




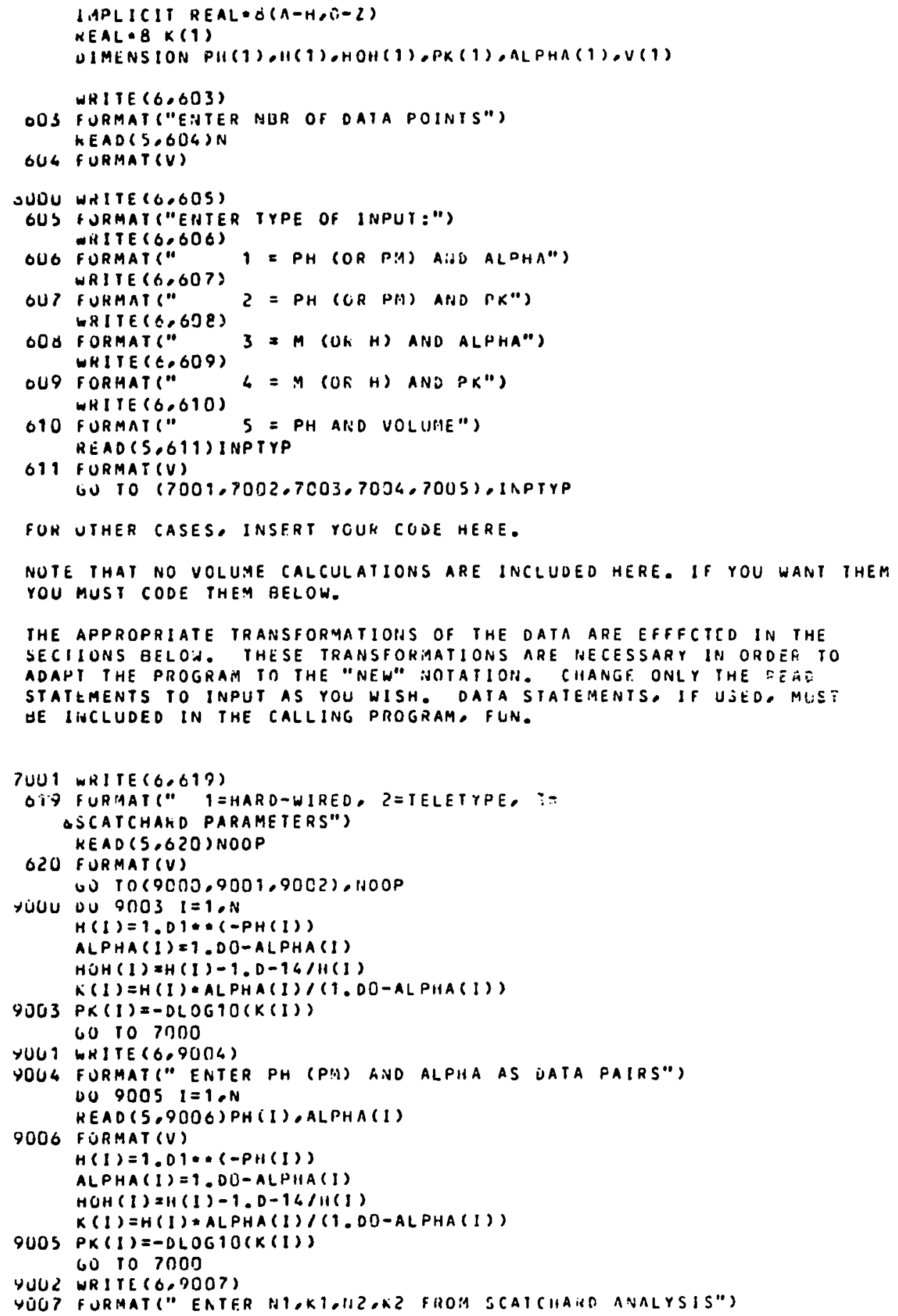




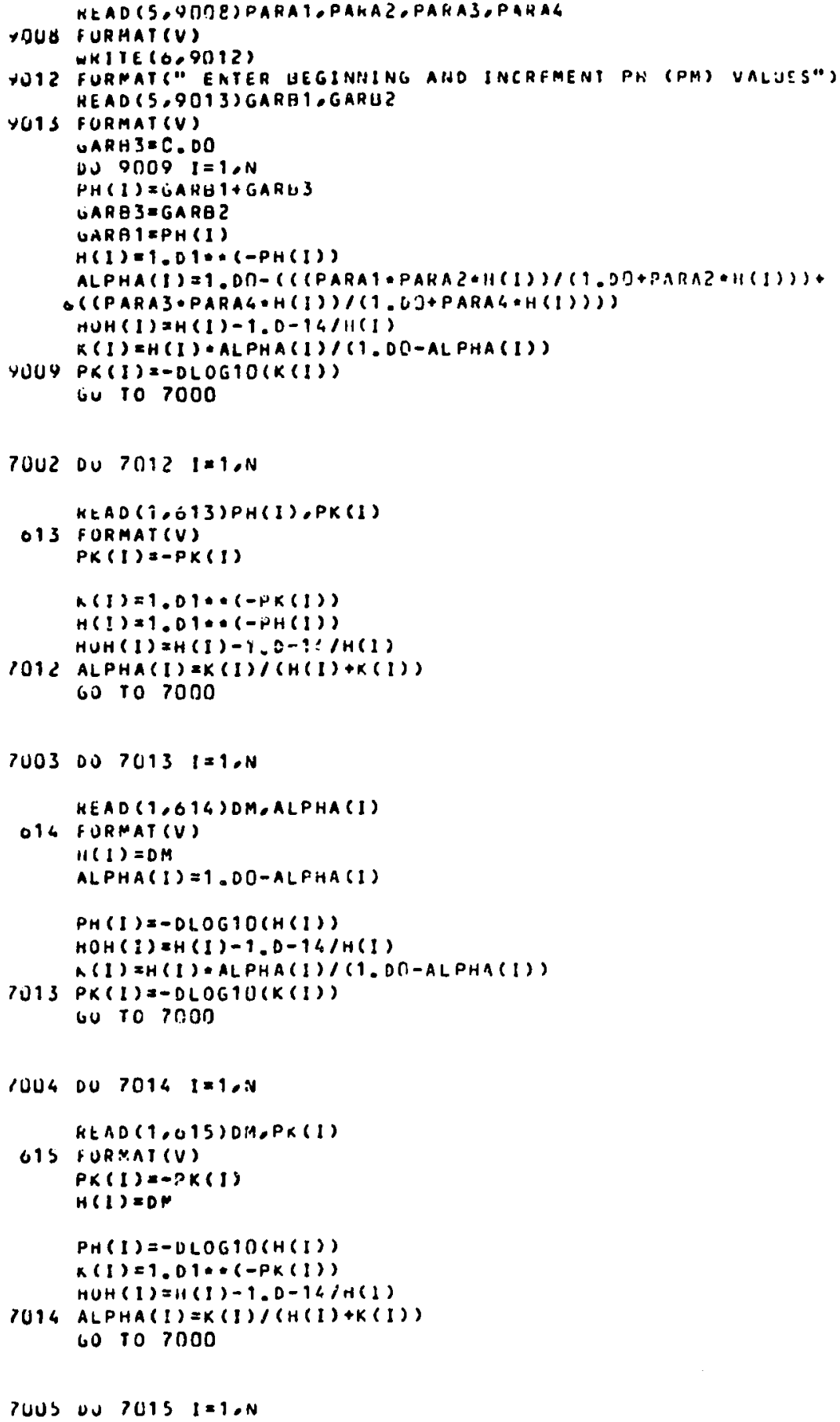




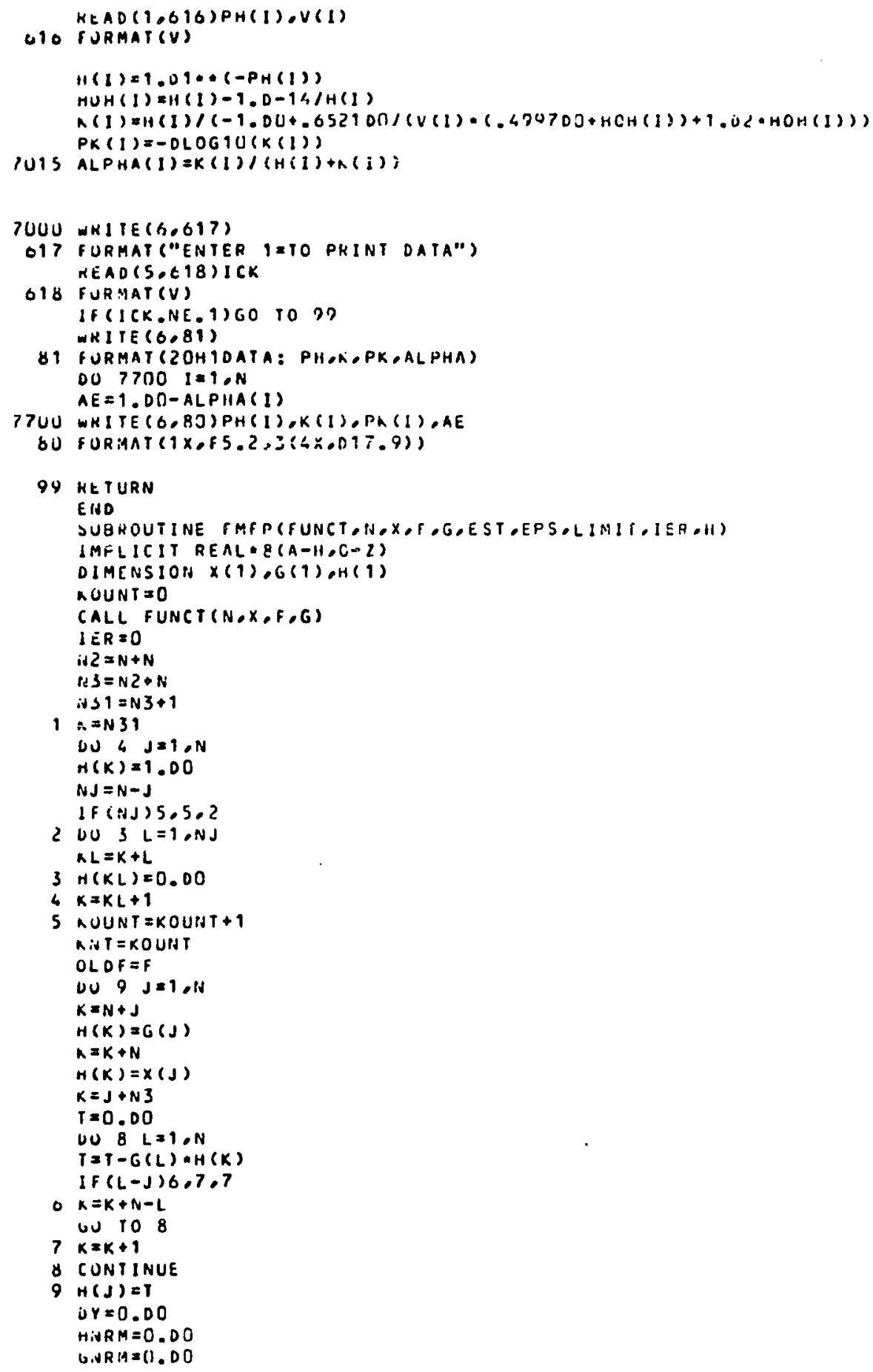




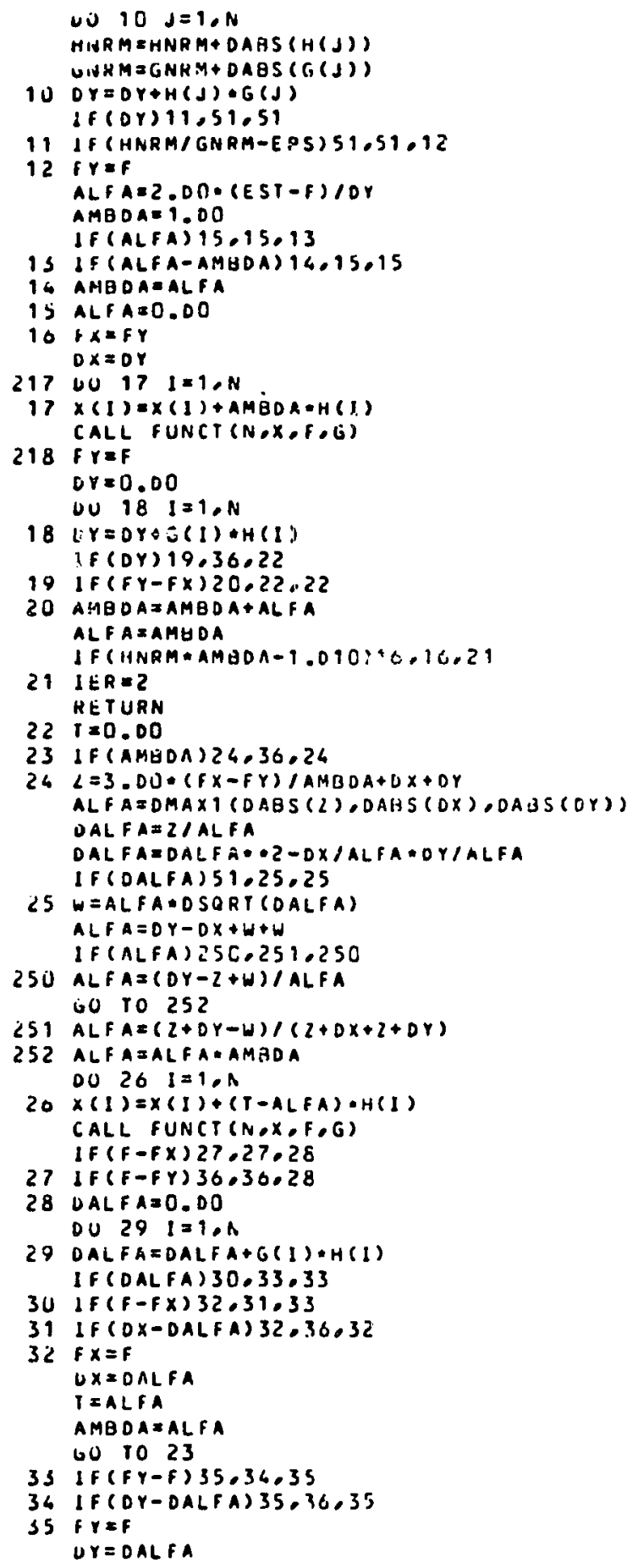




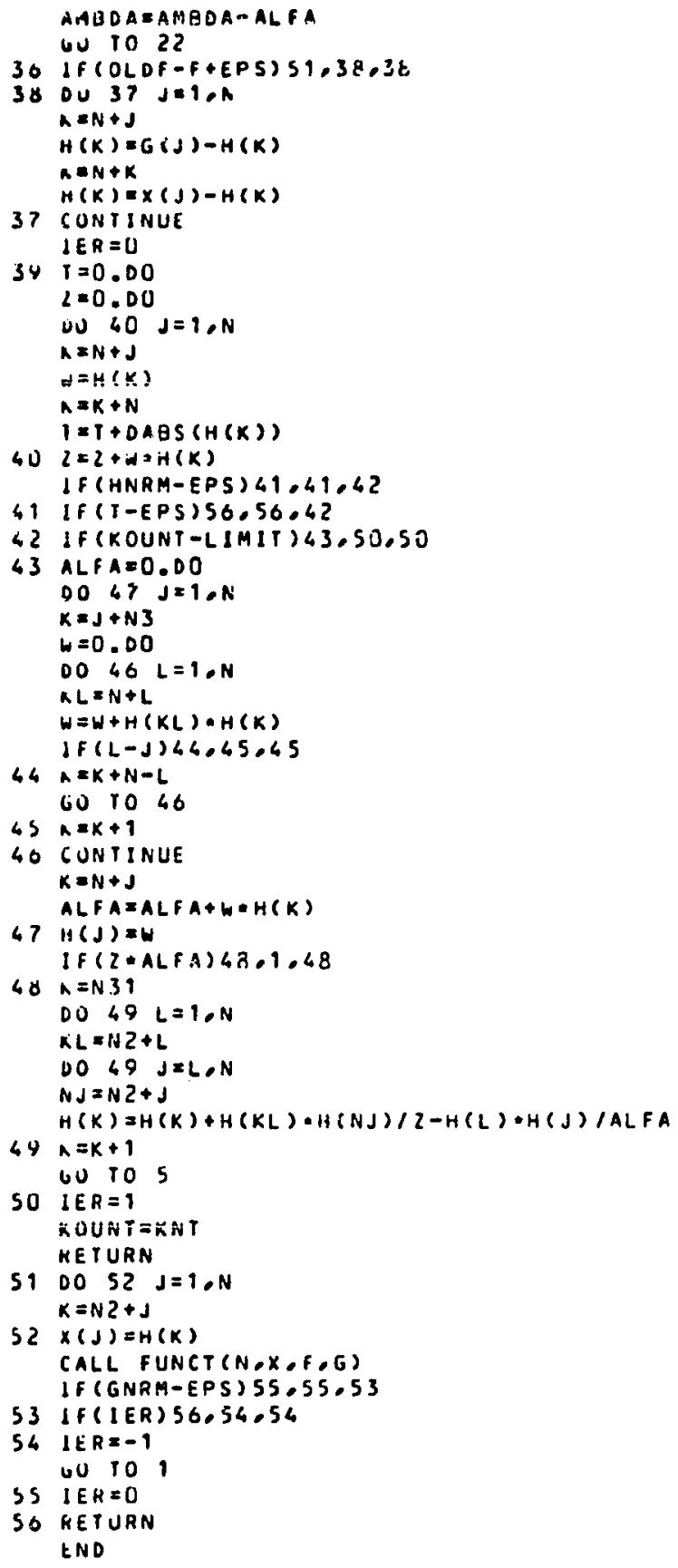


APPENDIX D: AMINO ACID DATA

The following tables give the total amino acids in $\mu \mathrm{M}$ for unfiltered samples. Missing data are indicated by an asterisk. 
WR10

$\begin{array}{crrrrrrrr}\text { DATE } & \text { ALA } & \text { GLY } & \text { VAL } & \text { THR } & \text { SER } & \text { LEU } & \text { ILE } & \text { PRO } \\ 09-10-77 & 0.40 & 1.00 & 0.00 & 0.00 & 0.60 & 0.00 & 0.00 & 0.00 \\ 10-08-77 & 0.00 & 0.00 & 0.00 & 0.00 & 0.00 & 0.00 & 0.00 & 0.00 \\ 11-11-77 & 0.00 & 0.00 & 0.00 & 0.00 & 0.00 & 0.00 & 0.00 & 0.00 \\ 12-21-77 & 0.00 & 0.00 & 0.00 & 0.00 & 0.00 & 0.00 & 0.00 & 0.00 \\ 01-15-78 & 0.00 & 0.00 & 0.00 & 0.00 & 0.00 & 0.00 & 0.00 & 0.00 \\ 02-18-78 & 0.34 & 1.03 & 0.19 & 0.20 & 1.15 & 0.09 & 0.30 & 0.08 \\ 03-19-78 & 0.00 & 0.00 & 0.00 & 0.00 & 0.00 & 0.00 & 0.00 & 0.00 \\ 04-15-78 & 0.04 & 0.08 & 0.00 & 0.00 & 0.03 & 0.00 & 0.00 & 0.00 \\ 05-13-78 & 0.26 & 0.54 & 0.00 & 0.00 & 0.00 & 0.00 & 0.00 & 0.00 \\ 06-12-78 & 0.04 & 0.09 & 0.00 & 0.00 & 0.02 & 0.00 & 0.00 & 0.00 \\ 07-14-78 & 0.22 & 0.23 & 0.05 & 0.02 & 0.08 & 0.00 & 0.00 & 0.00 \\ 08-19-78 & 0.16 & 0.17 & 0.05 & 0.05 & 0.12 & 0.03 & 0.00 & 0.06 \\ 09-18-78 & 0.07 & 0.12 & 0.00 & 0.00 & 0.00 & 0.00 & 0.00 & 0.00 \\ 10-14-73 & 0.10 & 0.14 & 0.00 & 0.02 & 0.13 & 0.00 & 0.00 & 0.00 \\ 11-18-78 & 0.05 & 0.06 & 0.00 & 0.00 & 0.00 & 0.00 & 0.00 & 0.00 \\ 12-17-78 & 0.06 & 0.06 & 0.00 & 0.00 & 0.02 & 0.00 & 0.00 & 0.00 \\ 01-13-79 & 0.16 & 0.23 & 0.02 & 0.01 & 0.17 & 0.00 & 0.00 & 0.00 \\ 02-17-79 & 0.12 & 0.08 & 0.00 & 0.00 & 0.02 & 0.01 & 0.00 & 0.00 \\ 03-15-79 & 0.00 & 0.00 & 0.00 & 0.00 & 0.00 & 0.00 & 0.00 & 0.00 \\ 04-14-79 & 0.00 & 0.00 & 0.00 & 0.00 & 0.00 & 0.00 & 0.00 & 0.00 \\ 05-19-79 & 0.00 & 0.00 & 0.00 & 0.00 & 0.28 & 0.00 & 0.00 & 0.00 \\ 06-17-79 & 0.08 & 0.08 & 0.00 & 0.57 & 0.04 & 0.00 & 0.00 & 0.38 \\ 07-14-79 & 0.00 & 0.00 & 0.00 & 0.00 & 0.00 & 0.00 & 0.00 & 0.00 \\ 08-11-79 & 0.00 & 0.00 & 0.00 & 0.00 & 0.00 & 0.00 & 0.00 & 0.00 \\ 09-08-79 & 0.00 & 0.00 & 0.00 & 0.00 & 0.00 & 0.00 & 0.00 & 0.00\end{array}$


WR10

\begin{tabular}{|c|c|c|c|c|c|c|c|c|}
\hline DATE & IET & $\mathrm{HE}$ & ASP & YS & TYR & GLU & ARG & \\
\hline $9-10-77$ & 0.00 & 0.60 & 0.00 & 0.00 & 0.00 & 0.30 & 0.00 & \\
\hline$-08-77$ & & 00 & & .00 & 00 & .00 & 00 & \\
\hline$-11-77$ & .00 & 00 & & & .00 & .00 & .00 & \\
\hline$-21-77$ & 0.00 & .00 & .00 & 0.00 & 0.00 & 0.00 & 0.00 & \\
\hline$-15-78$ & 0.00 & 0.00 & .00 & 0.00 & .00 & 0.00 & 0.00 & \\
\hline$-18-78$ & & .29 & & & & 0.56 & & \\
\hline$-19-78$ & 0.00 & .00 & .00 & & 0.00 & 0.00 & 0.00 & \\
\hline $1-15-78$ & 0.00 & 0.00 & .14 & 0.00 & 0.00 & 0.02 & 0.00 & \\
\hline$-13-78$ & 0.00 & .00 & 0 & 0.04 & .09 & 0.20 & .00 & \\
\hline$-12-78$ & 0.00 & 0.01 & 0.04 & & 0.00 & 0.05 & 0.14 & \\
\hline$-14-78$ & ח & 00 & & & & & & \\
\hline $3-19-78$ & 0.00 & .00 & & 0.13 & .04 & 0.08 & 0.06 & \\
\hline$-18-78$ & & & & & & 0.00 & & \\
\hline $0-14-78$ & & 0.00 & & & & & & \\
\hline$-18-78$ & 0.00 & .00 & .00 & 0.00 & .00 & 0.03 & .00 & \\
\hline$-17-78$ & & & & & & & & \\
\hline $1-13-79$ & 0.00 & 0.00 & .10 & 0.01 & & & 0.04 & \\
\hline $2-17-79$ & 0.00 & & & & & 0 & .00 & \\
\hline-79 & & & & & & & & \\
\hline $04-14-79$ & 0.00 & 0.00 & 0.10 & 0.00 & & 0.30 & 0.00 & \\
\hline $5-15$ & & & & & & 0.00 & & \\
\hline $06-17-79$ & & & & & & & & \\
\hline $07-14-79$ & & & & & & & & \\
\hline $8-11-79$ & 0.00 & & 0.00 & 0.00 & .00 & 0.00 & 0.00 & \\
\hline 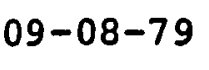 & & & & & & 0.0 & 0.00 & \\
\hline
\end{tabular}


DATE ALA GLY VAL THR SER LEU ILE PRO $\begin{array}{lllllllll}09-10-77 & 0.30 & 0.40 & 0.10 & 0.00 & 0.10 & 0.00 & 0.00 & 0.00\end{array}$ $\begin{array}{lllllllll}10-08-77 & 0.00 & 0.00 & 0.00 & 0.00 & 0.00 & 0.00 & 0.00 & 0.00\end{array}$ $\begin{array}{lllllllll}11-12-77 & 0.00 & 0.00 & 0.00 & 0.00 & 0.00 & 0.00 & 0.00 & 0.00\end{array}$ $12-21-77$

$\begin{array}{lllllllll}01-15-78 & 0.00 & 0.00 & 0.00 & 0.40 & 0.00 & 0.00 & 0.00 & 0.00\end{array}$ $\begin{array}{lllllllll}02-18-78 & 0.16 & 0.24 & 0.00 & 0.00 & 0.08 & 0.00 & 0.00 & 0.20\end{array}$ $\begin{array}{lllllllll}03-19-78 & 0.13 & 0.24 & 0.05 & 0.06 & 0.14 & 0.04 & 0.04 & 0.12\end{array}$ $\begin{array}{lllllllll}04-15-78 & 0.22 & 0.51 & 0.11 & 0.13 & 0.26 & 0.03 & 0.01 & 0.16\end{array}$ $\begin{array}{lllllllll}05-13-78 & 0.29 & 0.54 & 0.14 & 0.14 & 0.24 & 0.14 & 0.03 & 0.40\end{array}$ $\begin{array}{lllllllll}06-12-78 & 0.27 & 0.14 & 0.03 & 0.02 & 0.02 & 0.00 & 0.00 & 0.04\end{array}$ $\begin{array}{lllllllll}07-14-78 & 0.80 & 0.12 & 0.02 & 0.01 & 0.03 & 0.00 & 0.00 & 0.01\end{array}$ $\begin{array}{lllllllll}08-19-78 & 0.13 & 0.20 & 0.06 & 0.07 & 0.12 & 0.03 & 0.01 & 0.00\end{array}$ $\begin{array}{lllllllll}09-18-78 & 0.05 & 0.20 & 0.02 & 0.00 & 0.12 & 0.00 & 0.00 & 0.02\end{array}$ $\begin{array}{lllllllll}10-14-78 & 0.07 & 0.11 & 0.01 & 0.02 & 0.05 & 0.00 & 0.00 & 0.02\end{array}$ $\begin{array}{lllllllll}11-18-78 & 0.06 & 0.08 & 0.02 & 0.00 & 0.05 & 0.00 & 0.00 & 0.00\end{array}$ $12-17-78 \quad$ * $\quad$ * $\quad$ * $\quad$ * $\quad$ * $\quad$ * $\quad$ * $\begin{array}{lllllllll}01-13-79 & 0.26 & 0.38 & 0.06 & 0.10 & 0.21 & 0.02 & 0.00 & 0.05\end{array}$ $\begin{array}{lllllllll}02-17-79 & 0.30 & 0.42 & 0.23 & 0.17 & 0.29 & 0.09 & 0.07 & 0.10\end{array}$ 03-15-79 $\quad$ * $\quad$ * $\quad$ * $\quad$ * $\quad$ * $\quad$ * $\quad$ * $\begin{array}{lllllllll}04-14-79 & 0.52 & 0.95 & 0.00 & 0.00 & 0.12 & 0.05 & 0.00 & 0.21\end{array}$ $\begin{array}{lllllllll}05-19-79 & 0.16 & 0.22 & 0.03 & 0.05 & 0.11 & 0.07 & 0.07 & 0.03\end{array}$ $\begin{array}{lllllllll}06-17-79 & 0.05 & 0.08 & 0.17 & 0.00 & 0.01 & 0.00 & 0.00 & 0.00\end{array}$ $\begin{array}{lllllllll}07-14-79 & 0.18 & 0.23 & 0.06 & 0.04 & 0.10 & 0.06 & 0.00 & 0.03\end{array}$ $\begin{array}{lllllllll}08-11-79 & 0.61 & 0.66 & 0.00 & 0.00 & 0.03 & 0.01 & 0.00 & 0.00\end{array}$ $\begin{array}{lllllllll}09-08-79 & 0.00 & 0.00 & 0.00 & 0.00 & 0.00 & 0.00 & 0.00 & 0.00\end{array}$ 
WR21

\begin{tabular}{|c|c|c|c|c|c|c|c|c|}
\hline DATE & MET & PHE & ASP & LYS & TYR & GLU & ARG & HIS \\
\hline $9-10-77$ & 0.00 & 0.00 & 0.00 & 0.00 & 0.00 & 0.00 & 0.00 & 0.00 \\
\hline $0-08-77$ & 0.00 & 0.00 & 0.00 & 0.00 & 0.00 & 0.00 & 0.00 & 0.00 \\
\hline $1-12-77$ & .00 & 0.00 & 0.00 & 0.00 & 0.00 & 0.00 & 0.00 & 0.00 \\
\hline $2-21-77$ & * & * & * & * & * & * & * & * \\
\hline $1-15-78$ & 0.00 & 0.20 & 0.00 & 0.00 & 0.00 & 0.20 & 0.00 & 0.00 \\
\hline $2-18-78$ & 0.18 & 0.00 & 0.07 & 0.07 & 0.00 & 0.07 & 0.00 & 0.07 \\
\hline $3-19-78$ & 0.12 & 0.06 & 0.13 & 0.16 & 0.04 & 0.00 & 0.11 & 0.06 \\
\hline $4-15-78$ & 0.08 & 0.01 & 0.24 & 0.08 & 0.00 & 0.24 & 0.00 & 0.00 \\
\hline $5-13-78$ & .00 & 0.00 & 0.33 & 0.15 & 0,00 & 0.41 & 0.00 & 0.00 \\
\hline $5-12-78$ & .00 & .00 & 0.10 & 0.07 & 0.00 & 0.15 & .00 & 0.00 \\
\hline $7-14-7$ & .0 & .03 & 0.10 & 0.02 & .00 & 0.07 & 00 & 0.00 \\
\hline $8-19-78$ & .00 & .00 & 0.12 & 0.06 & .03 & 0 . & & 0.00 \\
\hline $9-18-78$ & 0.00 & 0.00 & 0.08 & 0.00 & 0.00 & 0.08 & .00 & 0.00 \\
\hline $0-14-78$ & 0.00 & 0.00 & 0.02 & .00 & 0.00 & 0.02 & & .00 \\
\hline $1-1$ & .00 & .00 & 0.03 & .01 & 0.00 & 0.05 & 04 & 0.00 \\
\hline $2-17-7$ & * & * & * & * & * & * & , & * \\
\hline $1-13-79$ & 0.08 & & & & 0.00 & 0.42 & & 0.00 \\
\hline $2-17-79$ & . & & & 0.14 & & 0.42 & & 00 \\
\hline $3-15$ & & & & & & & & 00 \\
\hline $4-14-79$ & 0.03 & 0.06 & 0.07 & 0.02 & 0.00 & 0.07 & & 0.00 \\
\hline $5-19-79$ & 0.09 & 0.04 & & & 0.00 & 0.14 & & 0.00 \\
\hline $17-79$ & & & & & & 0.21 & & 00 \\
\hline $07-14-79$ & 0.00 & 0.06 & 0.29 & 0.04 & 0.00 & 0.13 & 0.00 & 0.00 \\
\hline $8-11-79$ & & & & & & 0.00 & 0.00 & 0.00 \\
\hline $9-08-79$ & .00 & 0.00 & 0.00 & 0.00 & .00 & 0.02 & 0.00 & 0.00 \\
\hline
\end{tabular}


DATE ALA GLY VAL THR SER LEU ILE PRO

$\begin{array}{lllllllll}09-10-77 & 0.00 & 0.00 & 0.00 & 0.00 & 0.00 & 0.00 & 0.00 & 0.00\end{array}$

$\begin{array}{lllllllll}10-08-77 & 0.00 & 0.00 & 0.00 & 0.00 & 0.00 & 0.00 & 0.00 & 0.00\end{array}$

$\begin{array}{lllllllll}11-12-77 & 0.00 & 0.00 & 0.00 & 0.00 & 0.00 & 0.00 & 0.00 & 0.00\end{array}$

$\begin{array}{lllllllll}12-22-77 & 0.00 & 0.00 & 0.00 & 0.00 & 0.00 & 0.00 & 0.00 & 0.00\end{array}$

$\begin{array}{lllllllll}01-15-78 & 0.40 & 0.70 & 0.00 & 0.20 & 0.20 & 0.30 & 0.00 & 0.20\end{array}$

$\begin{array}{lllllllll}02-18-78 & 0.28 & 0.54 & 0.09 & 0.10 & 0.25 & 0.05 & 0.06 & 0.05\end{array}$

$\begin{array}{lllllllll}03-19-78 & 0.24 & 0.33 & 0.06 & 0.06 & 0.08 & 0.06 & 0.04 & 0.07\end{array}$

$\begin{array}{lllllllll}04-15-78 & 0.09 & 0.13 & 0.03 & 0.03 & 0.07 & 0.00 & 0.00 & 0.04\end{array}$

$\begin{array}{lllllllll}05-13-78 & 0.64 & 1.26 & 0.22 & 0.24 & 1.11 & 0.12 & 0.12 & 0.33\end{array}$

$\begin{array}{lllllllll}06-12-78 & 0.38 & 0.30 & 0.10 & 0.15 & 0.10 & 0.03 & 0.00 & 0.10\end{array}$

$\begin{array}{lllllllll}07-14-78 & 0.14 & 0.23 & 0.01 & 0.01 & 0.03 & 0.02 & 0.00 & 0.00\end{array}$

$\begin{array}{lllllllll}08-19-78 & 0.16 & 0.22 & 0.12 & 0.09 & 0.08 & 0.03 & 0.00 & 0.00\end{array}$

$\begin{array}{lllllllll}09-18-78 & 0.08 & 0.14 & 0.07 & 0.04 & 0.06 & 0.00 & 0.00 & 0.04\end{array}$

$\begin{array}{lllllllll}10-14-78 & 0.05 & 0.06 & 0.00 & 0.00 & 0.01 & 0.00 & 0.00 & 0.00\end{array}$

$\begin{array}{lllllllll}11-18-78 & 0.06 & 0.12 & 0.01 & 0.00 & 0.08 & 0.00 & 0.00 & 0.00\end{array}$

$\begin{array}{lllllllll}12-17-78 & 0.15 & 0.25 & 0.04 & 0.04 & 0.10 & 0.02 & 0.00 & 0.04\end{array}$

$\begin{array}{lllllllll}01-13-79 & 0.77 & 0.99 & 0.24 & 0.36 & 0.59 & 0.00 & 0.07 & 0.22\end{array}$

$\begin{array}{lllllllll}02-17-79 & 0.23 & 0.33 & 0.06 & 0.09 & 0.16 & 0.03 & 0.05 & 0.03\end{array}$

$\begin{array}{lllllllll}03-15-79 & 0.06 & 0.10 & 0.01 & 0.00 & 0.00 & 0.00 & 0.00 & 0.00\end{array}$

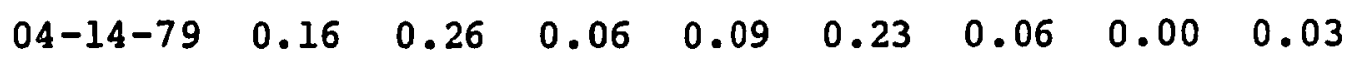

$\begin{array}{lllllllll}05-19-79 & 0.15 & 0.31 & 0.06 & 0.04 & 0.02 & 0.03 & 0.00 & 0.01\end{array}$

$\begin{array}{lllllllll}06-17-79 & 0.05 & 0.10 & 0.01 & 0.01 & 0.04 & 0.05 & 0.00 & 0.00\end{array}$

$\begin{array}{lllllllll}07-14-79 & 0.24 & 0.27 & 0.07 & 0.07 & 0.15 & 0.03 & 0.08 & 0.10\end{array}$

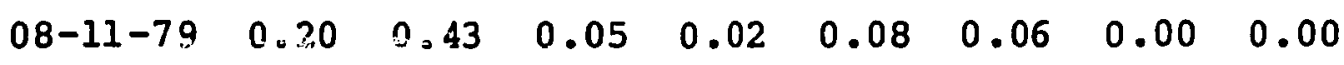

$\begin{array}{lllllllll}09-08-79 & 0.14 & 0.12 & 0.02 & 0.08 & 0.12 & 0.09 & 0.00 & 0.02\end{array}$ 
DATE MET PHE ASP LYS TYR GLU ARG HIS $\begin{array}{lllllllll}09-10-77 & 0.36 & 0.00 & 0.00 & 0.00 & 0.00 & 0.00 & 0.00 & 0.00\end{array}$ $\begin{array}{lllllllll}10-08-77 & 0.00 & 0.00 & 0.00 & 0.00 & 0.00 & 0.00 & 0.00 & 0.00\end{array}$ $\begin{array}{lllllllll}11-12-77 & 0.00 & 0.00 & 0.00 & 0.00 & 0.00 & 0.00 & 0.00 & 0.00\end{array}$ $\begin{array}{lllllllll}12-22-77 & 0.00 & 0.00 & 0.00 & 0.00 & 0.00 & 0.00 & 0.00 & 0.00\end{array}$ $\begin{array}{lllllllll}01-15-78 & 0.00 & 0.00 & 0.50 & 0.10 & 0.00 & 0.20 & 0.00 & 0.00\end{array}$ $\begin{array}{lllllllll}02-18-78 & 0.05 & 0.02 & 0.22 & 0.04 & 0.00 & 0.18 & 0.00 & 0.06\end{array}$ $\begin{array}{lllllllll}03-19-78 & 0.00 & 0.04 & 0.16 & 0.03 & 0.00 & 0.09 & 0.00 & 0.06\end{array}$ $\begin{array}{lllllllll}04-5.5-78 & 0.06 & 0.00 & 0.12 & 0.02 & 0.00 & 0.09 & 0.00 & 0.21\end{array}$ $\begin{array}{lllllllll}05-13-78 & 0.00 & 0.18 & 0.53 & 0.13 & 0.00 & 1.05 & 0.12 & 0.00\end{array}$ $\begin{array}{lllllllll}06-12-78 & 0.17 & 0.00 & 0.57 & 0.04 & 0.00 & 0.13 & 0.06 & 0.11\end{array}$ $\begin{array}{lllllllll}07-14-78 & 0.11 & 0.02 & 0.04 & 0.02 & 0.00 & 0.05 & 0.00 & 0.00\end{array}$ $\begin{array}{lllllllll}08-19-78 & 0.07 & 0.00 & 0.12 & 0.02 & 0.00 & 0.09 & 0.06 & 0.00\end{array}$ $\begin{array}{lllllllll}09-18-78 & 0.00 & 0.00 & 0.08 & 0.04 & 0.00 & 0.06 & 0.03 & 0.00\end{array}$ $\begin{array}{lllllllll}10-14-78 & 0.00 & 0.00 & 0.00 & 0.00 & 0.00 & 0.01 & 0.00 & 0.00\end{array}$ $\begin{array}{lllllllll}11-18-78 & 0.00 & 0.00 & 0.04 & 0.01 & 0.00 & 0.04 & 0.04 & 0.14\end{array}$ $\begin{array}{lllllllll}12-17-78 & 0.06 & 0.00 & 0.14 & 0.04 & 0.00 & 0.12 & 0.00 & 0.12\end{array}$ $\begin{array}{lllllllll}01-13-79 & 0.11 & 0.09 & 0.80 & 0.23 & 0.00 & 0.72 & 0.06 & 0.23\end{array}$ $\begin{array}{lllllllll}02-17-79 & 0.05 & 0.01 & 0.33 & 0.11 & 0.00 & 0.25 & 0.03 & 0.21\end{array}$ $\begin{array}{lllllllll}03-15-79 & 0.00 & 0.00 & 0.15 & 0.00 & 0.00 & 0.05 & 0.00 & 0.03\end{array}$

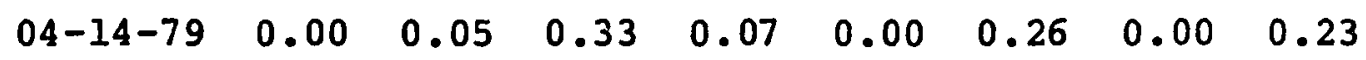
$\begin{array}{lllllllll}05-19-79 & 0.00 & 0.02 & 0.32 & 0.02 & 0.00 & 0.12 & 0.00 & 0.00\end{array}$ $\begin{array}{lllllllll}06-17-79 & 0.00 & 0.00 & 0.09 & 0.00 & 0.00 & 0.08 & 0.00 & 0.00\end{array}$ $\begin{array}{lllllllll}07-14-79 & 0.00 & 0.11 & 0.50 & 0.09 & 0.00 & 0.21 & 0.00 & 0.00\end{array}$ $\begin{array}{lllllllll}08-11-79 & 0.00 & 0.02 & 0.17 & 0.02 & 0.00 & 0.12 & 0.00 & 0.00\end{array}$ $\begin{array}{lllllllll}09-08-79 & 0.00 & 0.00 & 0.23 & 0.03 & 0.00 & 0.20 & 0.00 & 0.00\end{array}$ 


$\begin{array}{ccccccccc}\text { DATE } & \text { ALA } & \text { GLY } & \text { VAL } & \text { THR } & \text { SER } & \text { LEU } & \text { ILE } & \text { PRO } \\ 09-10-77 & 0.80 & 0.70 & 1.30 & 0.50 & 1.10 & 0.50 & 0.20 & 0.20 \\ 10-08-77 & 0.00 & 0.00 & 0.00 & 0.00 & 0.00 & 0.00 & 0.00 & 0.00 \\ 11-12-77 & 0.50 & 1.10 & 0.20 & 0.20 & 0.60 & 0.20 & 0.10 & 0.00 \\ 12-22-77 & 1.20 & 2.10 & 0.30 & 0.40 & 1.00 & 0.50 & 0.30 & 0.20 \\ 01-15-78 & 1.30 & 2.10 & 0.50 & 0.60 & 0.80 & 0.60 & 0.20 & 0.30 \\ 02-18-78 & 0.80 & 1.53 & 0.47 & 0.46 & 0.67 & 0.47 & 0.27 & 0.21 \\ 03-19-78 & 0.78 & 1.42 & 0.20 & 0.27 & 0.36 & 0.18 & 0.12 & 0.19 \\ 04-15-78 & 0.63 & 0.86 & 0.03 & 0.56 & 0.41 & 0.24 & 0.13 & 0.38 \\ 05-13-78 & 1.16 & 1.63 & 0.65 & 0.93 & 1.07 & 0.52 & 0.34 & 0.53 \\ 06-12-78 & 0.28 & 0.44 & 0.09 & 0.17 & 0.21 & 0.12 & 0.05 & 0.13 \\ 07-14-78 & 0.29 & 0.35 & 0.28 & 0.34 & 0.38 & 0.01 & 0.00 & 0.08 \\ 08-19-78 & 0.32 & 0.46 & 0.17 & 0.21 & 0.28 & 0.05 & 0.03 & 0.06 \\ 09-18-78 & 0.17 & 0.32 & 0.10 & 0.12 & 0.12 & 0.05 & 0.01 & 0.09 \\ 10-14-78 & 0.33 & 0.66 & 0.17 & 0.24 & 0.26 & 0.12 & 0.08 & 0.12 \\ 11-18-78 & 0.09 & 0.19 & 0.04 & 0.03 & 0.13 & 0.02 & 0.00 & 0.02 \\ 12-17-78 & 0.47 & 0.74 & 0.18 & 0.24 & 0.33 & 0.15 & 0.10 & 0.16 \\ 01-13-79 & 0.73 & 0.84 & 0.26 & 0.36 & 0.50 & 0.20 & 0.12 & 0.27 \\ 02-17-79 & 0.44 & 0.66 & 0.16 & 0.29 & 0.40 & 0.17 & 0.08 & 0.21 \\ 03-15-79 & 0.17 & 0.30 & 0.08 & 0.07 & 0.14 & 0.09 & 0.00 & 0.01 \\ 04-14-79 & 0.58 & 0.95 & 0.22 & 0.37 & 0.78 & 0.23 & 0.27 & 0.23 \\ 05-19-79 & 0.95 & 1.36 & 0.32 & 0.51 & 0.62 & 0.34 & 0.17 & 0.39 \\ 06-17-79 & 0.21 & 0.32 & 0.10 & 0.12 & 0.17 & 0.06 & 0.00 & 0.08 \\ 07-14-79 & 0.27 & 0.29 & 0.12 & 0.17 & 0.24 & 0.07 & 0.01 & 0.09 \\ 08-11-79 & 1.05 & 1.35 & 0.38 & 0.61 & 0.84 & 0.57 & 0.20 & 0.37 \\ 09-08-79 & 0.29 & 0.43 & 0.10 & 0.24 & 0.35 & 0.13 & 0.10 & 0.10\end{array}$


WR32

DATE MET PHE ASP LYS TYR GLU ARG HIS $\begin{array}{lllllllll}09-10-77 & 0.00 & 0.70 & 1.40 & 0.30 & 0.00 & 0.60 & 0.00 & 0.00\end{array}$ $\begin{array}{lllllllll}10-08-77 & 0.90 & 0.30 & 0.20 & 0.00 & 0.00 & 0.00 & 0.00 & 0.00\end{array}$ $\begin{array}{lllllllll}11-12-77 & 0.00 & 0.20 & 0.50 & 0.10 & 0.00 & 0.40 & 0.00 & 0.00\end{array}$ $\begin{array}{lllllllll}12-22-77 & 0.50 & 0.40 & 1.00 & 0.20 & 0.00 & 0.50 & 0.00 & 0.00\end{array}$ $\begin{array}{lllllllll}01-15-78 & 0.00 & 0.50 & 1.50 & 0.30 & 0.00 & 0.70 & 0.00 & 0.00\end{array}$ $\begin{array}{lllllllll}02-18-78 & 0.11 & 0.51 & 0.88 & 0.18 & 0.00 & 0.47 & 0.00 & 0.08\end{array}$ $\begin{array}{lllllllll}03-19-78 & 0.18 & 0.35 & 0.57 & 0.09 & 0.00 & 0.32 & 0.00 & 0.07\end{array}$ $\begin{array}{lllllllll}04-15-78 & 0.32 & 0.17 & 0.59 & 0.14 & 0.00 & 0.47 & 0.11 & 0.36\end{array}$

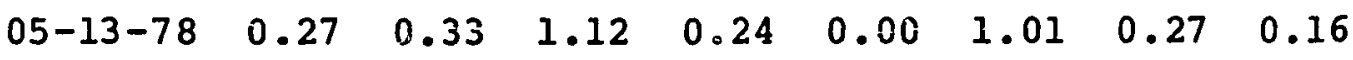
$\begin{array}{lllllllll}06-12-78 & 0.08 & 0.03 & 0.35 & 0.07 & 0.00 & 0.31 & 0.00 & 0.00\end{array}$ $\begin{array}{lllllllll}07-14-78 & 0.22 & 0.01 & 0.19 & 0.04 & 0.00 & 0.15 & 0.03 & 0.00\end{array}$ $\begin{array}{lllllllll}08-19-78 & 0.08 & 0.00 & 0.28 & 0.10 & 0.00 & 0.20 & 0.02 & 0.12\end{array}$ $\begin{array}{lllllllll}09-18-78 & 0.06 & 0.00 & 0.29 & 0.04 & 0.00 & 0.14 & 0.09 & 0.15\end{array}$ $\begin{array}{lllllllll}10-14-78 & 0.11 & 0.12 & 0.39 & 0.07 & 0.02 & 0.27 & 0.06 & 0.00\end{array}$ $\begin{array}{lllllllll}11-18-78 & 0.00 & 0.00 & 0.14 & 0.03 & 0.00 & 0.19 & 0.00 & 0.17\end{array}$ $\begin{array}{lllllllll}12-17-78 & 0.11 & 0.08 & 0.52 & 0.11 & 0.00 & 0.35 & 0.00 & 0.11\end{array}$ $\begin{array}{lllllllll}01-13-79 & 0.12 & 0.17 & 0.96 & 0.23 & 0.00 & 0.86 & 0.10 & 0.21\end{array}$ $\begin{array}{lllllllll}02-17-79 & 0.18 & 0.39 & 1.12 & 0.25 & 0.04 & 1.00 & 0.68 & 0.72\end{array}$ $\begin{array}{lllllllll}03-15-79 & 0.06 & 0.06 & 0.25 & 0.03 & 0.00 & 0.19 & 0.00 & 0.00\end{array}$ $\begin{array}{lllllllll}04-14-79 & 0.19 & 0.55 & 1.08 & 0.17 & 0.00 & 0.84 & 0.08 & 0.18\end{array}$ $\begin{array}{lllllllll}05-19-79 & 0.07 & 0.46 & 1.09 & 0.16 & 0.00 & 0.84 & 0.04 & 0.00\end{array}$ $\begin{array}{lllllllll}06-17-79 & 0.00 & 0.26 & 0.49 & 0.14 & 0.00 & 0.38 & 0.02 & 0.00\end{array}$ $\begin{array}{lllllllll}07-14-79 & 0.00 & 0.11 & 0.47 & 0.08 & 0.00 & 0.33 & 0.00 & 0.00\end{array}$ $\begin{array}{lllllllll}08-11-79 & 0.69 & 0.39 & 1.73 & 0.33 & 0.00 & 1.38 & 0.06 & 0.35\end{array}$ $\begin{array}{lllllllll}09-08-79 & 0.32 & 0.18 & 0.51 & 0.06 & 0.00 & 0.41 & 0.00 & 0.09\end{array}$ 
WR50

DATE ALA GLY VAL THR SER LEU ILE PRO

\begin{tabular}{|c|c|c|c|c|c|c|c|c|}
\hline $09-10-77$ & * & $\star$ & * & $\star$ & * & * & $\star$ & * \\
\hline $10-08-77$ & * & * & * & * & * & $\star$ & * & * \\
\hline $11-12-77$ & 1.80 & 4.60 & 0.80 & 0.90 & 2.10 & 0.70 & 0.40 & 0.30 \\
\hline $12-21-77$ & 1.40 & 3.20 & 0.40 & 0.60 & 1.90 & 0.50 & 0.30 & 0.30 \\
\hline $01-15-78$ & 0.60 & 1.20 & 0.30 & 0.20 & 0.30 & 0.20 & 0.10 & 0.20 \\
\hline $02-18-78$ & 0.55 & 1.36 & 0.25 & 0.30 & 0.42 & 0.26 & 0.15 & 0.14 \\
\hline $03-19-78$ & 0.81 & 1.54 & 0.43 & 0.50 & 0.63 & 0.44 & 0.25 & 0.28 \\
\hline $04-15-78$ & 0.51 & 0.75 & 0.31 & 0.41 & C. 40 & 0.24 & 0.14 & 0.27 \\
\hline $05-13-78$ & 0.30 & 0.51 & 0.19 & 0.22 & 0.26 & 0.18 & 0.03 & 0.09 \\
\hline $06-12-78$ & 0.77 & 1.36 & 0.52 & 0.59 & 0.69 & 0.45 & 0.24 & 0.36 \\
\hline $07-14-78$ & 0.77 & 1.34 & 0.52 & 0.58 & 0.59 & 0.46 & 0.27 & 0.35 \\
\hline $08-19-78$ & * & $\star$ & * & * & 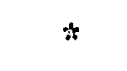 & $\star$ & * & * \\
\hline $09-18-78$ & * & * & * & * & * & * & $\star$ & * \\
\hline $10-14-78$ & * & * & * & * & * & * & * & * \\
\hline $11-18-78$ & * & $\star$ & * & $\star$ & * & $\star$ & * & * \\
\hline $12-17-78$ & 1.52 & 2.40 & 0.65 & 1.02 & 1.14 & 0.64 & 0.34 & 0.62 \\
\hline $01-13-79$ & 1.00 & 1.15 & 0.33 & 0.53 & 0.69 & 0.39 & 0.15 & 0.37 \\
\hline $02-17-79$ & 0.31 & 0.62 & 0.13 & 0.29 & 0.38 & 0.17 & 0.08 & 0.20 \\
\hline $03-15-79$ & 0.18 & 0.30 & 0.08 & 0.08 & 0.15 & 0.07 & 0.00 & 0.00 \\
\hline $04-14-79$ & 0.88 & 1.25 & 0.38 & 0.56 & 0.96 & 0.38 & 0.19 & 0.25 \\
\hline $05-19-79$ & 0.96 & 1.33 & 0.34 & 0.41 & 0.71 & 0.37 & 0.19 & 0.33 \\
\hline $06-17-79$ & 0.95 & 1.52 & 0.34 & 0.55 & 0.72 & 0.38 & 0.19 & 0.33 \\
\hline $07-14-79$ & * & * & * & $\star$ & * & $*$ & * & $\star$ \\
\hline $08-11-79$ & * & * & * & $\star$ & * & * & * & $\star$ \\
\hline $09-08-79$ & * & * & * & $\star$ & * & $\star$ & $\star$ & * \\
\hline
\end{tabular}


WR50

DATE MET PHE ASP LYS TYR GLU ARG HIS

\begin{tabular}{|c|c|c|c|c|c|c|c|c|}
\hline $09-10-77$ & $\star$ & $\star$ & * & * & * & * & * & * \\
\hline $10-08-77$ & * & * & * & * & * & * & * & * \\
\hline $11-12-77$ & 0.30 & 0.60 & 1.90 & 0.30 & 0.00 & 1.20 & 0.00 & 0.00 \\
\hline $12-21-77$ & 0.40 & 0.60 & 1.20 & 0.20 & 0.00 & 0.90 & 0.00 & 0.00 \\
\hline $01-15-78$ & 0.10 & 0.10 & 0.70 & 0.10 & 0.00 & 0.30 & 0.00 & 0.00 \\
\hline $02-18-78$ & 0.09 & 0.17 & 0.62 & 0.08 & 0.00 & 0.30 & 0.00 & 0.06 \\
\hline $03-19-78$ & 0.24 & 0.56 & 0.86 & 0.20 & 0.00 & 0.42 & 0.00 & 0.06 \\
\hline $04-15-78$ & 0.20 & 0.12 & 0.52 & 0.15 & 0.00 & 0.40 & 0.14 & 0.21 \\
\hline $05-13-78$ & 0.09 & 0.00 & 0.20 & 0.06 & 0.07 & 0.28 & 0.53 & 0.14 \\
\hline $06-12-78$ & 0.96 & 0.12 & 0.71 & 0.21 & 0.00 & 0.53 & 0.30 & 0.00 \\
\hline $07-14-78$ & 0.22 & 0.38 & 0.67 & 0.1 .9 & 0.00 & 0.44 & 0.26 & 0.12 \\
\hline $08-19-78$ & * & * & * & * & * & * & * & * \\
\hline $09-18-78$ & * & $\star$ & * & * & * & $\star$ & * & $\star$ \\
\hline $10-14-78$ & * & $\star$ & * & * & * & * & * & * \\
\hline $11-18-78$ & * & * & * & * & * & * & * & $\dot{x}$ \\
\hline $12-17-78$ & 1.52 & 2.40 & 0.65 & 1.02 & 1.14 & 0.64 & 0.34 & 0.62 \\
\hline $01-13-79$ & 0.15 & 0.34 & 1.28 & 0.26 & 0.00 & 1.02 & 0.03 & 0.21 \\
\hline $02-17-79$ & 0.07 & 0.17 & 0.88 & 0.08 & 0.02 & 0.60 & 0.13 & 0.02 \\
\hline $03-15-79$ & 0.03 & 0.05 & 0.33 & 0.03 & 0.00 & 0.19 & 0.03 & 0.03 \\
\hline $04-14-79$ & 0.28 & 0.82 & 1.23 & 0.31 & 0.00 & 1.31 & 0.16 & 0.19 \\
\hline $05-19-79$ & 0.23 & 0.70 & 1.18 & 0.23 & 0.00 & 1.06 & 0.02 & 0.00 \\
\hline $06-17-79$ & 0.32 & 0.77 & 1.30 & 0.26 & 0.08 & 0.92 & 0.17 & 0.14 \\
\hline $07-14-79$ & * & * & * & $\star$ & * & * & $\star$ & $\star$ \\
\hline $08-11-79$ & * & $\star$ & * & * & $\star$ & * & $\star$ & * \\
\hline $29-08-79$ & * & * & * & $\star$ & $\star$ & * & * & * \\
\hline
\end{tabular}


WR56

\begin{tabular}{|c|c|c|c|c|c|c|c|c|}
\hline DA] & ALA & GLY & VAL & THR & ERR & LEI & ILE & \\
\hline $9-10-77$ & 0.00 & 0.00 & 0.00 & 0.00 & 0.00 & 0.00 & 0.00 & \\
\hline$-08-77$ & 00 & 00 & .00 & .00 & .00 & .00 & .00 & \\
\hline$-12-77$ & & & .50 & 0.80 & 1.80 & 0.40 & .30 & \\
\hline$-21-77$ & 1.10 & 2.70 & .30 & 1.10 & 1.20 & 0.50 & 0.00 & \\
\hline$-15-78$ & .60 & 1.30 & .30 & & 0.30 & 0.40 & 0.20 & \\
\hline$-18-78$ & .84 & 1.62 & 0.45 & 0.47 & 0.64 & 0.47 & 0.29 & \\
\hline$-19-78$ & 0.67 & 1.60 & 0.29 & & 0.56 & .28 & 0.19 & \\
\hline$-15-78$ & .62 & .83 & 0.33 & & 0.51 & 0.32 & 0.21 & \\
\hline$-13-78$ & 0.50 & 0.85 & 0.28 & 0.43 & 0.53 & 0.21 & 0.09 & \\
\hline$=12=78$ & .56 & .97 & & & 0.45 & .30 & 0.15 & \\
\hline$-14-78$ & 0.40 & .76 & 0.20 & & 0.36 & 0.17 & 0.09 & \\
\hline$-19-78$ & 0.10 & 0.14 & .05 & & & .03 & & \\
\hline$-18-78$ & 0.11 & 0.16 & .06 & & 0.09 & .01 & 0.00 & \\
\hline $1-14-78$ & 0.08 & 0.11 & .02 & & .04 & .00 & 0.00 & \\
\hline$-18-78$ & & & & & & & & \\
\hline $2-17-78$ & 0.66 & 2.10 & 0.43 & 0.62 & 0.88 & 0.62 & 0.34 & \\
\hline $1-13-79$ & $\cdot .45$ & & & & & & & \\
\hline$-17-79$ & & & & & & & & \\
\hline $3-15-79$ & 0.40 & 0.55 & & & 0.32 & 0.15 & 0.05 & \\
\hline $4-14-79$ & 0.50 & & & & & & & \\
\hline $05-19-79$ & 0.64 & 0.92 & & & & & 0.11 & \\
\hline $16-17-79$ & & & & & & & & \\
\hline $07-14-79$ & 0.02 & 0.02 & 0.00 & 0.00 & 0.00 & 0.00 & 0.00 & \\
\hline $08-11-79$ & & & & & & & & \\
\hline $9-08-7$ & 0 & 0.00 & & & 0 & & 00 & \\
\hline
\end{tabular}


WR56

DATE MET PHE ASP LYS TYR GLU ARG HIS

\begin{tabular}{|c|c|c|c|c|c|c|c|c|}
\hline $09-10-77$ & $\star$ & * & * & * & * & * & * & * \\
\hline $10-08-77$ & 1.50 & 2.60 & 0.90 & 0.40 & 0.00 & 0.40 & 0.00 & 0.00 \\
\hline $1-12-77$ & 0.00 & 0.40 & 1.50 & 0.20 & 0.00 & 0.70 & 0.00 & 0.00 \\
\hline $2-21-77$ & 0.60 & 0.40 & 1.10 & 0.40 & 0.00 & 0.70 & 0.00 & 0.00 \\
\hline $1-15-78$ & 0.00 & 0.10 & 0.80 & 0.20 & 0.00 & 0.40 & 0.00 & 0.20 \\
\hline $2-18-78$ & 0.12 & 0.43 & 0.90 & 0.17 & 0.00 & 0.50 & 0.00 & 0.06 \\
\hline $3-19-78$ & 0.15 & 0.36 & 0.73 & 0.12 & 0.00 & 0.32 & 0.00 & 0.05 \\
\hline $4-15-78$ & 0.22 & 0.13 & 0.65 & 0.18 & 0.00 & 0.52 & 0.29 & 0.22 \\
\hline $5-13-78$ & 0.00 & 0.37 & 0.66 & 0.14 & 0.00 & 0.39 & 0.25 & 0.00 \\
\hline $6-12-78$ & 0.13 & 0.23 & 0.54 & 0.11 & 0.00 & 0.37 & 0.00 & 0.00 \\
\hline $7-14-78$ & 0.10 & 0.37 & 0.54 & 0.14 & 0.00 & 0.37 & 0.10 & 0.16 \\
\hline $8-19-78$ & 0.00 & 0.05 & $0.1 I$ & 0.04 & 0.00 & 0.11 & 0.00 & 0.00 \\
\hline $9-18-78$ & 0.04 & 0.00 & 0.08 & 0.02 & 0.00 & 0.07 & 0.02 & 0.15 \\
\hline $10-14-78$ & 0.00 & 0.00 & 0.11 & 0.02 & 0.00 & 0.04 & 0.00 & 0.00 \\
\hline $1-18-78$ & 0.00 & 0.00 & 0.06 & 0.01 & 0.00 & 0.22 & 0.00 & 0.15 \\
\hline $12-17-78$ & 0.32 & 0.58 & 1.65 & 0.27 & 0.41 & 1.06 & 0.10 & 0.18 \\
\hline $01-13-79$ & 0.11 & 0.19 & 0.58 & 0.11 & 0.00 & 0.48 & 0.03 & 0.21 \\
\hline $02-17-79$ & 0.05 & & & 0.05 & & & & 0.05 \\
\hline $03-15-79$ & 0.12 & 0.15 & 0.48 & 0.09 & 0.00 & 0.10 & 0.01 & 0.05 \\
\hline $04-14-79$ & 0.28 & 0.08 & 0.42 & 0.13 & 0.07 & 0.77 & 0.27 & 0.16 \\
\hline $05-19-79$ & 0.16 & 0.43 & 0.83 & 0.08 & & & & 0.00 \\
\hline $06-17-79$ & 0.17 & 0.40 & & 0.14 & 0.06 & & 0.00 & 0.00 \\
\hline $07-14-79$ & 0.00 & 0.00 & 0.00 & 0.00 & 0.00 & 0.01 & 0.00 & 0.00 \\
\hline $08-11-79$ & 0.00 & 0.02 & 0.14 & 0.01 & 0.00 & 0.07 & 0.00 & 0.00 \\
\hline $9-08-79$ & 0.00 & 0.00 & 0.00 & 0.00 & 0.00 & .00 & 0.00 & 0.00 \\
\hline
\end{tabular}




$\begin{array}{ccccccccc}\text { DATE } & \text { ALA } & \text { GLY } & \text { VAL } & \text { THR } & \text { SER } & \text { LEU } & \text { ILE } & \text { PRO } \\ 09-10-77 & 0.00 & 0.00 & 0.00 & 0.00 & 0.00 & 0.00 & 0.00 & 0.00 \\ 10-08-77 & 0.00 & 0.00 & 0.00 & 0.00 & 0.00 & 0.00 & 0.00 & 0.00 \\ 11-12-77 & 1.10 & 1.70 & 0.40 & 0.40 & 2.10 & 0.20 & 0.20 & 0.00 \\ 12-22-77 & 0.90 & 2.00 & 0.40 & 0.40 & 1.30 & 0.40 & 0.20 & 0.20 \\ 01-15-78 & 0.20 & 0.40 & 0.10 & 0.10 & 0.10 & 0.10 & 0.10 & 0.10 \\ 02-18-78 & 0.00 & 0.00 & 0.00 & 0.00 & 0.00 & 0.00 & 0.00 & 0.00 \\ 03-19-78 & 0.26 & 0.42 & 0.11 & 0.16 & 0.25 & 0.09 & 0.06 & 0.09 \\ 04-15-78 & 0.22 & 0.35 & 0.12 & 0.13 & 0.17 & 0.02 & 0.00 & 0.10 \\ 05-13-78 & 0.37 & 0.43 & 0.08 & 0.11 & 0.16 & 0.12 & 0.00 & 0.05 \\ 06-12-78 & 0.18 & 0.31 & 0.08 & 0.09 & 0.12 & 0.05 & 0.01 & 0.00 \\ 07-14-78 & 0.08 & 0.12 & 0.02 & 0.00 & 0.00 & 0.00 & 0.00 & 0.00 \\ 08-19-78 & 0.06 & 0.09 & 0.02 & 0.02 & 0.02 & 0.03 & 0.00 & 0.00 \\ 09-18-78 & 0.05 & 0.08 & 0.01 & 0.00 & 0.03 & 0.00 & 0.00 & 0.00 \\ 10-14-78 & 0.06 & 0.06 & 0.02 & 0.01 & 0.04 & 0.01 & 0.00 & 0.00 \\ 11-18-78 & 0.05 & 0.10 & 0.00 & 0.00 & 0.08 & 0.00 & 0.00 & 0.00 \\ 12-17-78 & 0.32 & 0.63 & 0.14 & 0.18 & 0.24 & 0.09 & 0.02 & 0.10 \\ 01-13-79 & 0.19 & 0.38 & 0.07 & 0.10 & 0.18 & 0.04 & 0.01 & 0.04 \\ 02-17-79 & 0.25 & 0.32 & 0.11 & 0.12 & 0.20 & 0.03 & 0.02 & 0.06 \\ 03-15-79 & 0.13 & 0.21 & 0.05 & 0.03 & 0.07 & 0.03 & 0.00 & 0.00 \\ 04-14-79 & 0.31 & 0.27 & 0.02 & 0.02 & 0.25 & 0.10 & 0.00 & 0.00 \\ 05-19-79 & 0.27 & 0.40 & 0.11 & 0.17 & 0.15 & 0.09 & 0.02 & 0.07 \\ 06-17-79 & 0.00 & 0.00 & 0.00 & 0.00 & 0.00 & 0.00 & 0.00 & 0.00 \\ 07-14-79 & 0.03 & 0.01 & 0.00 & 0.00 & 0.02 & 0.00 & 0.00 & 0.00 \\ 08-11-79 & 0.00 & 0.00 & 0.00 & 0.00 & 0.00 & 0.00 & 0.00 & 0.00 \\ 09-08-79 & 0.00 & 0.00 & 0.00 & 0.00 & 0.00 & 0.00 & 0.00 & 0.00\end{array}$


WR67

DATE MET PHE ASP LYS TYR GLU ARG HIS

$\begin{array}{lllllllll}09-10-77 & 0.00 & 0.00 & 0.00 & 0.00 & 0.00 & 0.00 & 0.00 & 0.00\end{array}$

$\begin{array}{lllllllll}10-08-77 & 0.00 & 0.00 & 0.00 & 0.00 & 0.00 & 0.00 & 0.00 & 0.00\end{array}$

$\begin{array}{lllllllll}11-12-77 & 0.00 & 0.40 & 0.30 & 0.20 & 0.00 & 0.40 & 0.00 & 0.00\end{array}$

$\begin{array}{lllllllll}12-22-77 & 0.40 & 0.40 & 0.60 & 0.20 & 0.00 & 0.60 & 0.00 & 0.00\end{array}$

$\begin{array}{lllllllll}01-15-78 & 0.20 & 0.20 & 0.40 & 0.10 & 0.00 & 0.10 & 0.00 & 0.20\end{array}$

$\begin{array}{lllllllll}02-18-78 & 0.00 & 0.00 & 0.00 & 0.00 & 0.00 & 0.00 & 0.00 & 0.00\end{array}$

$\begin{array}{lllllllll}03-19-78 & 0.09 & 0.02 & 0.26 & 0.06 & 0.00 & 0.24 & 0.00 & 0.15\end{array}$

$\begin{array}{lllllllll}04-15-78 & 0.09 & 0.00 & 0.22 & 0.05 & 0.00 & 0.20 & 0.04 & 0.10\end{array}$

$\begin{array}{lllllllll}05-13-78 & 0.00 & 0.06 & 0.13 & 0.04 & 0.00 & 0.12 & 0.00 & 0.00\end{array}$

$\begin{array}{lllllllll}06-12-78 & 0.00 & 0.00 & 0.22 & 0.06 & 0.00 & 0.15 & 0.03 & 0.00\end{array}$

$\begin{array}{lllllllll}07-14-78 & 0.00 & 0.00 & 0.00 & 0.00 & 0.00 & 0.00 & 0.00 & 0.00\end{array}$

$\begin{array}{lllllllll}08-19-78 & 0.00 & 0.00 & 0.05 & 0.00 & 0.00 & 0.04 & 0.06 & 0.15\end{array}$

$\begin{array}{lllllllll}09-18-78 & 0.00 & 0.00 & 0.05 & 0.00 & 0.00 & 0.00 & 0.00 & 0.00\end{array}$

$\begin{array}{lllllllll}10-14-78 & 0.00 & 0.00 & 0.00 & 0.00 & 0.00 & 0.02 & 0.00 & 0.00\end{array}$

$\begin{array}{lllllllll}11-18-78 & 0.00 & 0.00 & 0.07 & 0.00 & 0.00 & 0.18 & 0.00 & 0.14\end{array}$

$\begin{array}{lllllllll}12-17-78 & 0.09 & 0.06 & 0.47 & 0.08 & 0.02 & 0.28 & 0.00 & 1.27\end{array}$

$\begin{array}{lllllllll}01-13-79 & 0.07 & 0.11 & 0.32 & 0.07 & 0.01 & 0.22 & 0.02 & 0.17\end{array}$

$\begin{array}{lllllllll}02-17-79 & 0.00 & 0.00 & 0.27 & 0.06 & 0.00 & 0.26 & 0.00 & 0.24\end{array}$

$\begin{array}{lllllllll}03-15-79 & 0.03 & 0.00 & 0.17 & 0.04 & 0.00 & 0.00 & 0.06 & 0.05\end{array}$

$\begin{array}{lllllllll}04-14-79 & 0.00 & 0.00 & 0.21 & 0.00 & 0.00 & 0.37 & 0.00 & 0.00\end{array}$

$\begin{array}{lllllllll}05-19-79 & 0.06 & 0.16 & 0.38 & 0.05 & 0.00 & 0.26 & 0.00 & 0.00\end{array}$

$\begin{array}{lllllllll}06-17-79 & 0.00 & 0.00 & 0.07 & 0.00 & 0.00 & 0.05 & 0.00 & 0.00\end{array}$

$\begin{array}{lllllllll}07-14-79 & 0.00 & 0.00 & 0.01 & 0.00 & 0.00 & 0.05 & 0.00 & 0.00\end{array}$

$\begin{array}{lllllllll}08-11-79 & 0.00 & 0.00 & 0.05 & 0.00 & 0.00 & 0.04 & 0.00 & 0.00\end{array}$

$\begin{array}{lllllllll}09-08-79 & 0.00 & 0.00 & 0.01 & 0.00 & 0.00 & 0.03 & 0.00 & 0.00\end{array}$ 
WR80

$\begin{array}{ccccccccc}\text { DATE } & \text { ALA } & \text { GLY } & \text { VAL } & \text { THR } & \text { SER } & \text { LEU } & \text { ILE } & \text { PRO } \\ 09-10-77 & 0.00 & 0.00 & 0.00 & 0.00 & 0.00 & 0.00 & 0.00 & 0.00 \\ 10-08-77 & 0.00 & 0.00 & 0.00 & 0.00 & 0.00 & 0.00 & 0.00 & 0.00 \\ 11-11-77 & 0.00 & 0.00 & 0.00 & 0.00 & 0.00 & 0.00 & 0.00 & 0.00 \\ 12-21-77 & 0.40 & 0.60 & 0.00 & 0.00 & 0.00 & 0.00 & 0.00 & 0.10 \\ 01-15-78 & 0.20 & 0.20 & 0.20 & 0.10 & 0.20 & 0.10 & 0.00 & 0.10 \\ 02-18-78 & 0.00 & 0.00 & 0.00 & 0.00 & 0.00 & 0.00 & 0.00 & 0.00 \\ 03-19-78 & 0.12 & 0.21 & 0.05 & 0.06 & 0.08 & 0.01 & 0.00 & 0.06 \\ 04-15-78 & 0.26 & 0.31 & 0.11 & 0.19 & 0.17 & 0.07 & 0.07 & 0.17 \\ 05-13-78 & 0.19 & 0.32 & 0.09 & 0.11 & 0.15 & 0.02 & 0.00 & 0.06 \\ 06-12-78 & 0.24 & 0.32 & 0.04 & 0.08 & 0.13 & 0.03 & 0.00 & 0.04 \\ 07-14-78 & 0.12 & 0.18 & 0.04 & 0.05 & 0.08 & 0.00 & 0.00 & 0.00 \\ 08-19-78 & 0.00 & 0.00 & 0.00 & 0.00 & 0.00 & 0.00 & 0.00 & 0.00 \\ 09-18-78 & 0.18 & 0.31 & 0.13 & 0.03 & 0.16 & 0.00 & 0.00 & 0.08 \\ 10-14-78 & 0.07 & 0.11 & 0.02 & 0.01 & 0.06 & 0.00 & 0.00 & 0.00 \\ 11-18-78 & 0.05 & 0.09 & 0.00 & 0.00 & 0.06 & 0.00 & 0.00 & 0.00 \\ 12-17-78 & 0.13 & 0.26 & 0.05 & 0.06 & 0.10 & 0.03 & 0.00 & 0.02 \\ 01-13-79 & 0.27 & 0.39 & 0.07 & 0.12 & 0.20 & 0.03 & 0.04 & 0.07 \\ 02-17-79 & 0.61 & 0.88 & 0.19 & 0.24 & 0.54 & 0.07 & 0.07 & 0.14 \\ 03-15-79 & 0.05 & 0.07 & 0.02 & 0.00 & 0.03 & 0.00 & 0.00 & 0.00 \\ 04-14-79 & 0.09 & 0.19 & 0.00 & 0.00 & 0.00 & 0.04 & 0.00 & 0.34 \\ 05-19-79 & 0.29 & 0.39 & 0.13 & 0.13 & 0.16 & 0.12 & 0.05 & 0.08 \\ 06-17-79 & 0.12 & 0.21 & 0.05 & 0.04 & 0.08 & 0.01 & 0.00 & 0.00 \\ 07-14-79 & 0.04 & 0.04 & 0.00 & 0.00 & 0.02 & 0.00 & 0.00 & 0.00 \\ 08-11-79 & 0.14 & 0.21 & 0.03 & 0.07 & 0.14 & 0.05 & 0.00 & 0.01 \\ 05-08-79 & 0.08 & 0.01 & 0.00 & 0.09 & 0.07 & 0.06 & 0.00 & 0.00\end{array}$


WR80

\begin{tabular}{|c|c|c|c|c|c|c|c|c|}
\hline DATE & MET & PHE & ASP & LYS & TYR & GLU & ARG & $4 T_{0}$ \\
\hline $9-10-77$ & .00 & .00 & 0.00 & 0.00 & 0.00 & 0.00 & 0.00 & 0.00 \\
\hline$-08-77$ & .60 & .10 & 30 & 20 & 00 & & & .0 \\
\hline $1-77$ & .00 & .00 & .00 & 30 & 0.00 & 0.00 & 0.00 & 0.0 \\
\hline $2-21-77$ & .50 & .20 & 0.40 & 0.10 & 0.10 & 0.10 & 0.00 & 0.01 \\
\hline $1-15-78$ & .10 & 0.10 & 0.30 & 0.10 & 0.00 & & 00 & 0.0 \\
\hline $18-78$ & .00 & .00 & 0.00 & 00 & 0.00 & 0.00 & 0.00 & 0.00 \\
\hline $3-19-78$ & .04 & 00 & 12 & 2 & & & & 0.00 \\
\hline $4-15-78$ & .08 & .03 & .25 & 07 & 0.00 & & & 0.11 \\
\hline $5-13-78$ & .13 & .01 & 5 & & 0.00 & & & $0,0 S$ \\
\hline $6-12-78$ & .10 & .02 & .20 & & & & & 0.06 \\
\hline $4-78$ & 6 & & 99 & & & & & 00 \\
\hline $8-19-78$ & .00 & .00 & 00 & .00 & 0.00 & & & \\
\hline $9-18=78$ & .0 & & & & & & & 0.00 \\
\hline $0-14-78$ & & & & & & & & 0 \\
\hline $8-78$ & & & & & & & & \\
\hline $2-1$ & .0 & 00 & & 4 & .00 & & & 0.00 \\
\hline $1-1$ & & & & & & & & \\
\hline a to & & & & & & & & \\
\hline $3-2 x+3$ & & & & & & & & \\
\hline $04-14-79$ & & & & & & & & \\
\hline $05-19-79$ & 0.0 & & & & & & & \\
\hline $06-17-79$ & & & & & & & & \\
\hline $07-14-79$ & & & & & & & & 0.00 \\
\hline $08-11-79$ & & & & & & & & \\
\hline $99-08-$ & 1.00 & 0.01 & 0.18 & 0.02 & 0.00 & 0.12 & 0.00 & 0. \\
\hline
\end{tabular}




\begin{tabular}{|c|c|c|c|c|c|c|c|c|}
\hline DATE & ALA & GLY & VAL & THR & SER & LEU & ILE & PRO \\
\hline $09-11-77$ & * & * & * & * & $\star$ & * & * & * \\
\hline $10-08-77$ & 0.00 & 0.00 & 0.00 & 0.00 & 0.00 & 0.00 & 0.00 & 0.00 \\
\hline $1-11-77$ & * & $\star$ & * & * & * & * & * & * \\
\hline $12-21-77$ & * & * & * & * & * & * & * & * \\
\hline 01-15-78 & * & * & * & * & * & * & * & * \\
\hline $02-18-78$ & * & * & * & * & * & * & * & * \\
\hline $03-19-78$ & * & $\star$ & * & * & * & * & * & * \\
\hline $04-15-78$ & 0.04 & 0.06 & 0.00 & 0.00 & 0.04 & 0.00 & 0.00 & 0.01 \\
\hline $05-13-78$ & 0.03 & 0.05 & 0.00 & 0.00 & 0.05 & 0.00 & 0.00 & 0.00 \\
\hline $06-12-78$ & 0.00 & 0.00 & 0.00 & 0.00 & 0.00 & 0.00 & 0.00 & 0.00 \\
\hline $07-14-78$ & 0.04 & 0.05 & 0.00 & 0.00 & 0.01 & 0.00 & 0.00 & 0.00 \\
\hline $08-19-78$ & 0.10 & 0.09 & 0.00 & 0.00 & 0.00 & 0.00 & 0.00 & 0.00 \\
\hline $09-18-78$ & 0.05 & 0.03 & 0.00 & 0.00 & 0.02 & 0.00 & 0.00 & 0.02 \\
\hline $10-14-78$ & 0.00 & 0.04 & 0.00 & 0.00 & 0.04 & 0.00 & 0.00 & 0.00 \\
\hline $11-18-78$ & 0.00 & 0.00 & 0.00 & 0.00 & 0.00 & 0.00 & 0.00 & 0.00 \\
\hline $12-17-78$ & * & * & $=$ & * & * & $\star$ & * & * \\
\hline $01-13-79$ & * & * & * & * & * & * & * & * \\
\hline $02-17-79$ & * & * & * & * & * & * & * & * \\
\hline $03-15-79$ & * & * & * & * & * & * & * & $\star$ \\
\hline $04-14-79$ & 0.00 & 1.04 & 0.00 & 0.00 & 0.00 & 0.00 & 0.00 & 0.00 \\
\hline $05-19-79$ & * & $\star$ & 4 & $\star$ & * & * & * & $\star$ \\
\hline $06-17-79$ & * & * & * & $\star$ & * & * & * & $\star$ \\
\hline $07-14-79$ & 0.00 & 0.00 & 0.00 & 0.00 & 0.00 & 0.00 & 0.00 & 0.00 \\
\hline $08-11-79$ & 0.05 & 0.13 & 0.01 & 0.01 & 0.14 & 0.00 & 0.00 & 0.02 \\
\hline $99-08-79$ & 0.00 & 0.00 & 0.00 & 0.00 & 0.00 & 0.00 & 0.00 & 0.00 \\
\hline
\end{tabular}


BS10

DATE MET PHE ASP LYS TYR GLU ARG HIS

\begin{tabular}{|c|c|c|c|c|c|c|c|c|}
\hline $09-11-77$ & * & $\star$ & * & * & * & * & * & * \\
\hline $10-08-77$ & 1.80 & 2.30 & 0.00 & 0.40 & 0.40 & 0.00 & 0.00 & 0.00 \\
\hline $11-11-77$ & $\star$ & * & $\star$ & * & $\star$ & $\star$ & $\star$ & * \\
\hline $12-21-77$ & $\star$ & $\star$ & * & $\Rightarrow$ & * & * & * & * \\
\hline $01-15-78$ & $\star$ & * & * & * & $\star$ & * & $\star$ & * \\
\hline $02-18-78$ & $\star$ & * & $\star$ & * & $\star$ & * & $\star$ & $\star$ \\
\hline $03-19-78$ & * & * & * & * & $\star$ & * & $\star$ & $\star$ \\
\hline $04-15-78$ & 0.00 & 0.00 & 0.00 & 0.00 & 0.00 & 0.04 & 0.00 & 0.00 \\
\hline $05-13-78$ & 0.00 & 0.00 & 0.00 & 0.00 & 0.00 & 0.00 & 0.00 & 0.00 \\
\hline $06-12-78$ & 0.00 & 0.00 & 0.00 & 0.00 & 0.00 & 0.00 & 0.00 & 0.00 \\
\hline $07-14-78$ & 0.00 & 0.00 & 0.04 & 0.00 & 0.00 & 0.03 & 0.00 & 0.00 \\
\hline $08-19-78$ & 0.00 & 0.13 & 0.24 & 0.03 & 0.00 & 0.17 & 0.00 & 0.00 \\
\hline $09-18-78$ & 0.00 & 0.00 & 0.06 & 0.00 & 0.00 & 0.00 & 0.00 & 0.00 \\
\hline $10-14-78$ & 0.00 & 0.00 & 0.00 & 0.00 & 0.00 & 0.02 & 0.00 & 0.00 \\
\hline $11-18-78$ & 0.00 & 0.00 & 0.00 & 0.00 & 0.00 & 0.01 & 0.00 & 0.00 \\
\hline $12-17-78$ & $\star$ & * & $\star$ & * & * & * & * & $*$ \\
\hline $01-13-79$ & $\star$ & $\star$ & * & * & * & * & $\star$ & xi \\
\hline $02-17-79$ & $\star$ & * & $\star$ & * & * & $\star$ & $\star$ & $\star$ \\
\hline $03-15-79$ & $*$ & $\star$ & $\star$ & * & $\star$ & $\star$ & $\star$ & * \\
\hline $04-14-79$ & 0.00 & 0.02 & 0.13 & 0.00 & 0.00 & 0.16 & 0.00 & 0.00 \\
\hline $05-19-79$ & * & * & $\star$ & * & $\star$ & $\star$ & * & * \\
\hline $06-17-79$ & $\star$ & * & * & * & * & $\star$ & $\div$ & $\star$ \\
\hline $07-14-79$ & 0.00 & 0.00 & 0.00 & 0.00 & 0.00 & 0.00 & 0.00 & 0.00 \\
\hline $08-11-79$ & 0.00 & 0.00 & 0.08 & 0.01 & 0.00 & 0.08 & 0.00 & 0.00 \\
\hline $09-08-79$ & 0.00 & 0.00 & 0.00 & 0.00 & 0.00 & 0.00 & 0.00 & 0.00 \\
\hline
\end{tabular}


KL10

\begin{tabular}{|c|c|c|c|c|c|c|c|c|}
\hline DATE & ALA & GLY & VAL & THR & SER & LEU & ILE & \\
\hline $9-10-77$ & 1.00 & 1.90 & 0.50 & 0.60 & 1.00 & 0.70 & 0.50 & 0 \\
\hline $0-08-77$ & .00 & .00 & 0.00 & 0.00 & 0.00 & 0.00 & .00 & \\
\hline $1-11-77$ & .40 & .80 & 3.30 & .50 & 4.00 & 5.40 & 90 & \\
\hline $2-21-77$ & 0.00 & 0.00 & 0.00 & 0.00 & 0.00 & 0.00 & 00 & \\
\hline $1-15-78$ & .10 & 0.20 & 0.10 & 0.10 & 0.00 & 0.20 & 00 & \\
\hline $2-18-78$ & 0.00 & 0.00 & 0.00 & 0.00 & 0.00 & 0.00 & .00 & \\
\hline $3-19-78$ & 0.45 & 0.60 & 0.31 & 0.36 & 0.38 & 0.27 & 16 & \\
\hline $4-15-78$ & 1.03 & .24 & 0.77 & .65 & 0.72 & .64 & & \\
\hline $95-13-78$ & 0.33 & 0.44 & 0.15 & 0.18 & 0.20 & .07 & .04 & \\
\hline $6-12-78$ & .55 & 0.73 & 0.28 & 0.37 & 0.42 & .22 & & \\
\hline $14-78$ & .4 & 0.73 & 0.19 & .30 & 0.31 & .09 & & \\
\hline $8-19-78$ & 0.55 & 0.73 & 0.34 & .49 & 0.40 & .27 & & \\
\hline $99-18-78$ & & & & & & & & \\
\hline $4-78$ & 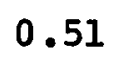 & & 0.23 & .29 & 0 & 12 & & \\
\hline $1-18$ & 0.3 & 0.45 & 0.13 & .18 & 0.22 & $=05$ & & \\
\hline $2-17-78$ & & & & & 4 & & & \\
\hline 1-13-79 & 3 & & & & & & & \\
\hline $2-17-79$ & .2 & 0.46 & & 11 & 0.3 & 04 & & \\
\hline $03-15-79$ & 0.00 & 0.00 & 0.00 & 0.00 & 0.00 & 0.00 & & \\
\hline $04-14-79$ & & & & & & & & \\
\hline 79 & 0.61 & 0.67 & 0.26 & & 0.30 & 0.31 & & \\
\hline $06-17-79$ & & & & & 0.3 & & & \\
\hline $07-14-79$ & 0.23 & & & & 0.21 & & & \\
\hline $8-11-79$ & 1.4 & & & & & & & \\
\hline $9-08$ & 8 & 39 & .19 & & 2.10 & 2.11 & 1.04 & \\
\hline
\end{tabular}


KL10

DATE MET PHE ASP LYS TYR GLU ARG HIS

$\begin{array}{lllllllll}09-10-77 & 0.00 & 1.10 & 1.40 & 0.20 & 0.00 & 0.80 & 0.00 & 0.00\end{array}$

$\begin{array}{lllllllll}10-08-77 & 0.00 & 0.00 & 0.00 & 0.00 & 0.00 & 0.00 & 0.00 & 0.00\end{array}$

$\begin{array}{lllllllll}11-11-77 & 0.80 & 2.60 & 9.30 & 1.70 & 0.00 & 3.40 & 0.00 & 1.30\end{array}$

$\begin{array}{lllllllll}12-21-77 & 0.00 & 0.00 & 0.00 & 0.00 & 0.00 & 0.00 & 0.00 & 0.00\end{array}$

$\begin{array}{lllllllll}01-15-78 & 0.10 & 0.00 & 0.10 & 0.10 & 0.00 & 0.10 & 0.00 & 0.10\end{array}$

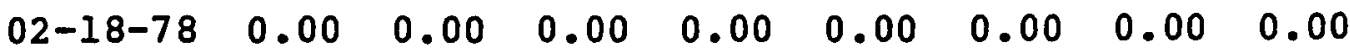

$\begin{array}{lllllllll}03-19-78 & 0.11 & 0.06 & 0.49 & 0.16 & 0.05 & 0.38 & 0.02 & 0.20\end{array}$

$\begin{array}{lllllllll}04-15-78 & 0.23 & 0.24 & 0.95 & 0.41 & 0.00 & 0.80 & 0.41 & 0.00\end{array}$

$\begin{array}{lllllllll}05-13-78 & 0.07 & 0.04 & 0.26 & 0.05 & 0.00 & 0.18 & 0.04 & 0.12\end{array}$

$\begin{array}{lllllllll}06-12-78 & 0.09 & 0.14 & 0.56 & 0.15 & 0.04 & 0.40 & 0.06 & 0.15\end{array}$

$\begin{array}{lllllllll}07-14-78 & 0.06 & 0.04 & 0.40 & 0.09 & 0.00 & 0.24 & 0.06 & 0.15\end{array}$

$\begin{array}{lllllllll}08-19-78 & 0.08 & 0.36 & 0.65 & 0.27 & 0.03 & 0.38 & 0.08 & 0.16\end{array}$

$\begin{array}{lllllllll}09-18-78 & 0.11 & 0.23 & 1.03 & 0.20 & 0.04 & 0.65 & 0.18 & 0.24\end{array}$

$\begin{array}{lllllllll}10-14-78 & 0.08 & 0.08 & 0.46 & 0.10 & 0.00 & 0.31 & 0.04 & 0.14\end{array}$

$\begin{array}{lllllllll}11-18-78 & 0.00 & 0.00 & 0.00 & 0.00 & 0.00 & 0.01 & 0.00 & 0.00\end{array}$

$\begin{array}{lllllllll}12-17-78 & 0.10 & 0.41 & 1.11 & 0.24 & 0.06 & 0.74 & 0.03 & 0.18\end{array}$

$\begin{array}{lllllllll}01-13-79 & 0.08 & 0.14 & 0.60 & 0.12 & 0.04 & 0.48 & 0.12 & 0.20\end{array}$

$\begin{array}{lllllllll}02-17-79 & 0.00 & 0.00 & 0.34 & 0.07 & 0.01 & 0.47 & 0.00 & 0.15\end{array}$

$\begin{array}{lllllllll}03-15-79 & 0.00 & 0.00 & 0.00 & 0.00 & 0.00 & 0.00 & 0.00 & 0.00\end{array}$

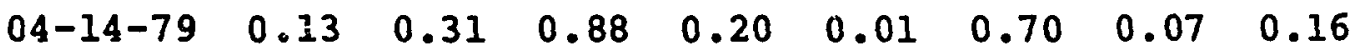

$\begin{array}{lllllllll}05-19-79 & 0.07 & 0.12 & 0.60 & 0.17 & 0.00 & 0.59 & 0.07 & 0.00\end{array}$

$\begin{array}{lllllllll}06-17-79 & 0.00 & 0.10 & 0.57 & 0.45 & 0.00 & 0.48 & 0.00 & 0.00\end{array}$

$\begin{array}{lllllllll}07-14-79 & 0.18 & 0.26 & 0.44 & 0.07 & 0.00 & 0.31 & 0.00 & 0.12\end{array}$

$\begin{array}{lllllllll}08-11-79 & 0.22 & 0.59 & 2.69 & 0.52 & 0.00 & 2.07 & 0.03 & 0.49\end{array}$

$\begin{array}{lllllllll}09-08-79 & 0.21 & 0.67 & 3.87 & 0.80 & 0.00 & 3.47 & 0.74 & 0.97\end{array}$ 
DATE ALA GLY VAL THR SER LEU ILE PRO $\begin{array}{lllllllll}09-10-77 & 0.00 & 0.00 & 0.00 & 0.00 & 0.00 & 0.00 & 0.00 & 0.00\end{array}$ $\begin{array}{lllllllll}10-08-77 & 0.00 & 0.00 & 0.00 & 0.00 & 0.00 & 0.00 & 0.00 & 0.00\end{array}$ $\begin{array}{lllllllll}11-12-77 & 0.00 & 0.00 & 0.00 & 0.00 & 0.00 & 0.00 & 0.00 & 0.00\end{array}$ $\begin{array}{lllllllll}12-22-77 & 0.00 & 0.00 & 0.00 & 0.00 & 0.00 & 0.00 & 0.000 & 0.000\end{array}$ $\begin{array}{lllllllll}01-15-78 & 0.00 & 0.00 & 0.00 & 0.00 & 0.00 & 0.40 & 0.00 & 0.00\end{array}$ $\begin{array}{lllllllll}02-18-78 & 0.00 & 0.00 & 0.00 & 0.00 & 0.00 & 0.00 & 0.00 & 0.00\end{array}$ $\begin{array}{lllllllll}03-19-78 & 0.08 & 0.11 & 0.05 & 0.04 & 0.07 & 0.04 & 0.00 & 0.06\end{array}$ $\begin{array}{lllllllll}04-15-78 & 0.02 & 0.06 & 0.000 & 0.00 & 0.02 & 0.00 & 0.00 & 0.01\end{array}$ $\begin{array}{lllllllll}05-13-78 & 0.00 & 0.00 & 0.00 & 0.00 & 0.00 & 0.00 & 0.00 & 0.00\end{array}$ $\begin{array}{lllllllll}06-12-78 & 0.98 & 1.10 & 0.07 & 0.96 & 0.28 & 0.00 & 0.00 & 0.27\end{array}$ $\begin{array}{lllllllll}07-14-78 & 0.04 & 0.09 & 0.00 & 0.00 & 0.04 & 0.00 & 0.00 & 0.00\end{array}$ $\begin{array}{lllllllll}08-19-78 & 0.04 & 0.04 & 0.01 & 0.00 & 0.02 & 0.02 & 0.00 & 0.00\end{array}$ $\begin{array}{lllllllll}09-18-78 & 0.06 & 0.04 & 0.00 & 0.00 & 0.02 & 0.00 & 0.00 & 0.00\end{array}$ $\begin{array}{lllllllll}10-14-78 & 0.07 & 0.13 & 0.01 & 0.00 & 0.04 & 0.01 & 0.00 & 0.00\end{array}$ $\begin{array}{lllllllll}11-18-78 & 0.00 & 0.00 & 0.00 & 0.00 & 0.00 & 0.00 & 0.00 & 0.00\end{array}$ $\begin{array}{lllllllll}12-17-78 & 0.00 & 0.00 & 0.00 & 0.00 & 0.00 & 0.00 & 0.00 & 0.00\end{array}$ $\begin{array}{lllllllll}01-13-79 & 0.10 & 0.13 & 0.02 & 0.03 & 0.10 & 0.02 & 0.00 & 0.00\end{array}$ $\begin{array}{lllllllll}02-17-79 & 0.02 & 0.02 & 0.00 & 0.00 & 0.00 & 0.00 & 0.00 & 0.00\end{array}$ $\begin{array}{lllllllll}03-15-79 & 0.00 & 0.00 & 0.00 & 0.00 & 0.00 & 0.00 & 0.00 & 0.00\end{array}$ $\begin{array}{lllllllll}04-14-79 & 0.00 & 0.00 & 0.00 & 0.00 & 0.00 & 0.00 & 0.00 & 0.00\end{array}$ $\begin{array}{lllllllll}05-19-79 & 0.05 & 0.07 & 0.00 & 0.00 & 0.00 & 0.00 & 0.00 & 0.00\end{array}$ $\begin{array}{lllllllll}06-17-79 & 0.00 & 0.00 & 0.00 & 0.00 & 0.00 & 0.00 & 0.00 & 0.00\end{array}$ $\begin{array}{lllllllll}07-14-79 & 0.02 & 0.01 & 0.00 & 0.00 & 0.00 & 0.00 & 0.00 & 0.00\end{array}$ $\begin{array}{lllllllll}08-11-79 & 0.00 & 0.00 & 0.00 & 0.00 & 0.00 & 0.00 & 0.00 & 0.00\end{array}$ $\begin{array}{lllllllll}09-08-79 & 0.00 & 0.00 & 0.00 & 0.00 & 0.00 & 0.00 & 0.00 & 0.00\end{array}$ 
SC20

\begin{tabular}{|c|c|c|c|c|c|c|c|c|}
\hline DATE & MET & PHE & ASP & LYS & TYR & GL U & ARG & HIS \\
\hline $9-10-77$ & .00 & 0.00 & 0.00 & 0.00 & 0.00 & 0.00 & 0.00 & 0.00 \\
\hline $0-08-77$ & .00 & 0.00 & .00 & 0.00 & 0.00 & 0.00 & 0.00 & 0.00 \\
\hline $2-77$ & .00 & 0.00 & 0.00 & 0.00 & 0.00 & .00 & 0.00 & 0.00 \\
\hline $2-22-77$ & .50 & 0.20 & 0.20 & 0.10 & .00 & .10 & 0.00 & 0.00 \\
\hline $1-15-78$ & .50 & 0.20 & 0.30 & 0.10 & 0.00 & & & 0.00 \\
\hline $2-18-78$ & 1.00 & 0.00 & U. 00 & 0.00 & 0.00 & 0.00 & 0.00 & 0.00 \\
\hline $9-78$ & .06 & 0.07 & .12 & 0.02 & .00 & & 00 & 0.67 \\
\hline-78 & .10 & .00 & 0.07 & 0.00 & 0.00 & 0.04 & & 0.00 \\
\hline $5-13-78$ & 0.00 & 00 & & 0.00 & 0.00 & & & 0.00 \\
\hline $6-12-78$ & .67 & .29 & 0.44 & .10 & .00 & & & 0.00 \\
\hline-78 & .00 & .00 & .02 & 0.01 & 0.00 & & & 0.00 \\
\hline $8-19-78$ & .00 & .00 & .02 & .00 & .00 & & & 0.00 \\
\hline $9-18-78$ & .00 & & & 0.00 & 0.00 & & & 0.00 \\
\hline $0-14-7$ & .00 & .00 & & & & & & .00 \\
\hline $8-78$ & 0.00 & 00 & & 00 & & & & 0.00 \\
\hline $2-17-78$ & 0.00 & .00 & & 0.00 & & & & 0.00 \\
\hline $1-13-79$ & & & & & & & & 0.00 \\
\hline $2-17-79$ & 0.00 & .00 & & .00 & & & & 0.00 \\
\hline $3-15-79$ & 0.00 & & & & & & & 0.00 \\
\hline $04-14-73$ & 0.0 & 0.00 & & & & & & 0.00 \\
\hline אי & & & & & & & & 0.00 \\
\hline $66-17-7$ & 0.00 & & & 0.00 & & & & 0.00 \\
\hline $07-14-75$ & 0.00 & & & 0.00 & & & & 0.00 \\
\hline $06-i 1-79$ & & & & & & & & 0.00 \\
\hline $9-08-79$ & 0.00 & 0.00 & 0.00 & 0.00 & 0.00 & 0.00 & 0.00 & 0.00 \\
\hline
\end{tabular}


SR65

\begin{tabular}{|c|c|c|c|c|c|c|c|c|}
\hline DATE & ALA & GLY & VAL & THR & SER & LEU & ILE & PRO \\
\hline $99-10-77$ & 0.30 & 0.50 & 0.20 & 0.10 & 0.20 & 0.00 & 0.00 & 0.00 \\
\hline $0-08-77$ & 0.00 & 0.00 & 0.00 & 0.00 & 0.00 & 0.00 & 0.00 & 0.00 \\
\hline $1-12-77$ & 0.00 & 0.00 & 0.00 & 0.00 & 0.00 & 0.00 & 0.00 & .00 \\
\hline $2-22-77$ & 0.30 & 0.40 & 0.00 & 0.00 & 0.00 & 0.00 & 0.00 & 0.0 \\
\hline $1-15-78$ & 0.50 & 1.20 & 0.10 & 0.10 & 0.20 & 0.20 & 0.10 & 0.0 \\
\hline $2-18-78$ & 0.00 & 0.00 & 0.00 & 0.00 & 0.00 & 0.00 & 0.00 & .00 \\
\hline $3-19-78$ & 0.16 & 0.26 & 0.08 & 0.11 & 0.12 & 0.04 & 0.00 & 0.0 \\
\hline $4-15-78$ & 0.25 & 0.35 & $0 . .22$ & 0.16 & 0.18 & 0.04 & 0.07 & .1 \\
\hline $5-13-78$ & 0.20 & 0.28 & 0.06 & 0.06 & 0.10 & 0.02 & 0.00 & .0 \\
\hline $6-12-78$ & 0.17 & 0.23 & 0.09 & 0.15 & 0.11 & 0.02 & 0.00 & .0 \\
\hline $7-14-78$ & 0.16 & 0.23 & 0.05 & 0.06 & 0.10 & 0.02 & 0.00 & 0.0 \\
\hline $8-19-78$ & 0.12 & 0.14 & 0.05 & 0.07 & 0.04 & 0.03 & 0.00 & 0.0 \\
\hline $9-18-78$ & 0.13 & 0.23 & 0.06 & 0.08 & 0.11 & 0.02 & 0.00 & .0 \\
\hline $10-14-78$ & 0.00 & 0.00 & 0.00 & 0.00 & 0.00 & & 0.00 & .0 \\
\hline $1-18-78$ & 0.05 & 0.05 & 0.00 & 0.00 & 0.03 & .00 & 0.00 & 0.0 \\
\hline $12-17-78$ & 0.08 & 0.09 & 0.00 & 0.02 & 0.05 & 0.00 & 0.00 & 0.0 \\
\hline $01-13-79$ & 0.38 & 0.52 & & & 0.25 & & & 07 \\
\hline $2-17-79$ & 0.26 & 0.39 & 0.09 & 0.11 & 0.18 & .03 & 0.00 & .0 \\
\hline $03-15-79$ & 0.02 & 0.04 & 0.00 & 0.00 & 0.00 & 0.00 & 0.00 & 0.0 \\
\hline $04-14-79$ & 0.22 & 0.43 & 0.09 & 0.10 & 0.55 & 0.07 & 0.02 & 0.0 \\
\hline $05-19-79$ & 0.24 & 0.35 & 0.12 & 0.09 & 0,14 & 0.12 & 0.03 & 0.0 \\
\hline $06-17-79$ & * & * & * & * & $\star$ & $=$ & * & \\
\hline $07-14-79$ & 0.13 & 0.24 & 0.06 & 0.09 & 0.13 & 0.05 & 0.00 & 0.03 \\
\hline $08-11-79$ & 0.16 & 0.22 & 0.03 & 0.14 & 0.19 & 0.12 & 0.00 & \\
\hline $9-08-79$ & 0.11 & .10 & 0.01 & 0.08 & 0.09 & 0.05 & 0.00 & 0.0 \\
\hline
\end{tabular}


SR65

DATE MET PHE ASP LYS TYR GLU ARG HIS $\begin{array}{lllllllll}09-10-77 & 0.00 & 0.20 & 0.00 & 0.00 & 0.00 & 0.20 & 0.00 & 0.00\end{array}$ $\begin{array}{lllllllll}10-08-77 & 0.30 & 1.20 & 0.40 & 0.00 & 0.00 & 0.20 & 0.00 & 0.00\end{array}$ $\begin{array}{lllllllll}11-12-77 & 0.00 & 0.00 & 0.00 & 0.00 & 0.00 & 0.00 & 0.00 & 0.00\end{array}$ $\begin{array}{lllllllll}12-22-77 & 0.30 & 0.00 & 0.30 & 0.20 & 0.00 & 0.20 & 0.00 & 0.00\end{array}$ $\begin{array}{lllllllll}01-15-78 & 0.10 & 0.20 & 1.00 & 0.10 & 0.00 & 0.40 & 0.00 & 0.00\end{array}$ $\begin{array}{lllllllll}02-18-78 & 0.00 & 0.00 & 0.00 & 0.00 & 0.00 & 0.00 & 0.00 & 0.00\end{array}$ $\begin{array}{lllllllll}03-19-78 & 0.00 & 0.00 & 0.19 & 0.04 & 0.00 & 0.14 & 0.00 & 0.00\end{array}$ $\begin{array}{lllllllll}04-15-78 & 0.16 & 0.05 & 0.30 & 0.06 & 0.00 & 0.25 & 0.08 & 0.12\end{array}$ $\begin{array}{lllllllll}05-13-78 & 0.00 & 0.00 & 0.14 & 0.00 & 0.00 & 0.14 & 0.00 & 0.00\end{array}$ $\begin{array}{lllllllll}06-12-78 & 0.00 & 0.00 & 0.17 & 0.03 & 0.00 & 0.11 & 0.00 & 0.00\end{array}$ $\begin{array}{lllllllll}07-14-78 & 0.00 & 0.00 & 0.10 & 0.03 & 0.00 & 0.07 & 0.00 & 0.00\end{array}$ $\begin{array}{lllllllll}08-19-78 & 0.06 & 0.00 & 0.10 & 0.00 & 0.00 & 0.07 & 0.04 & 0.17\end{array}$ $\begin{array}{lllllllll}09-18-78 & 0.05 & 0.00 & \cdots 0.12 & 0.02 & 0.02 & 0.08 & 0.04 & 0.14\end{array}$ $\begin{array}{lllllllll}10-14-78 & 0.00 & 0.00 & 0.00 & 0.00 & 0.00 & 0.00 & 0.00 & 0.00\end{array}$ $\begin{array}{lllllllll}11-18-78 & 0.00 & 0.00 & 0.05 & 0.00 & 0.00 & 0.07 & 0.00 & 0.18\end{array}$ $\begin{array}{lllllllll}12-17-78 & 0.00 & 0.00 & 0.07 & 0.03 & 0.00 & 0.07 & 0.00 & 0.00\end{array}$ $\begin{array}{lllllllll}01-13-79 & 0.09 & 0.03 & 0.40 & 0.10 & 0.00 & 0.36 & 0.00 & 0.15\end{array}$ $\begin{array}{lllllllll}02-17-79 & 0.00 & 0.00 & 0.28 & 0.03 & 0.00 & 0.21 & 0.00 & 0.30\end{array}$ $\begin{array}{lllllllll}03-15-79 & 0.07 & 0.00 & 0.03 & 0.00 & 0.00 & 0.00 & 0.00 & 0.00\end{array}$

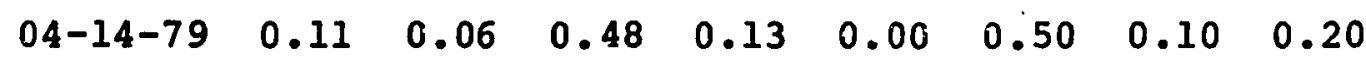
$\begin{array}{lllllllll}05-19-79 & 0.03 & 0.05 & 0.28 & 0.12 & 0.00 & 0.28 & 0.02 & 0.00\end{array}$ 06-17-79 $\quad$ * $\quad$ * $\quad$ * $\quad$ * $\quad$ * $\quad$ * $\quad$ * $\quad$ *

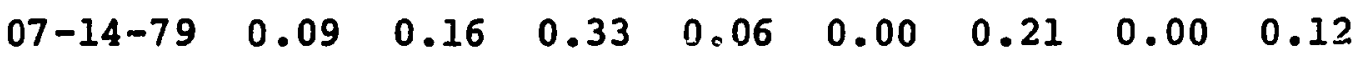
$\begin{array}{lllllllll}08-11-79 & 0.12 & 0.14 & 0.41 & 0.07 & 0.00 & 0.26 & 0.00 & 0.00\end{array}$ $\begin{array}{lllllllll}09-08-79 & 0.04 & 0.07 & 0.21 & 0.03 & 0.00 & 0.12 & 0.00 & 0.00\end{array}$ 